\title{
Drug Per Se Laws: A Review of Their Use in States
}

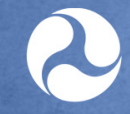

U.S. Department of Transportation National Highway Traffic Safety Administration 
This publication is distributed by the U.S. Department of Transportation, National Highway Traffic Safety Administration, in the interest of information exchange. The opinions, findings and conclusions expressed in this publication are those of the author(s) and not necessarily those of the Department of Transportation or the National Highway Traffic Safety Administration. The United States Government assumes no liability for its content or use thereof. If trade or manufacturers' names or products are mentioned, it is because they are considered essential to the object of the publication and should not be construed as an endorsement. The United States Government does not endorse products or manufacturers. 


\section{Technical Report Documentation Page}

\begin{tabular}{|c|c|c|c|c|}
\hline $\begin{array}{l}\text { 1. Report No. } \\
\text { DOT HS } 811317\end{array}$ & \multicolumn{2}{|c|}{ 2. Government Accession No. } & \multicolumn{2}{|l|}{ 3. Recipient's Catalog No. } \\
\hline \multirow{2}{*}{\multicolumn{3}{|c|}{$\begin{array}{l}\text { 4. Title and Subtitle } \\
\text { Drug Per Se Laws: A Review of Their Use in States }\end{array}$}} & \multicolumn{2}{|l|}{$\begin{array}{l}\text { 5. Report Date } \\
\text { July } 2010 \\
\end{array}$} \\
\hline & & & \multicolumn{2}{|c|}{ 6. Performing Organization Code } \\
\hline \multicolumn{3}{|c|}{$\begin{array}{l}\text { 7. Author(s) } \\
\text { John Lacey, Katharine Brainard, and Samantha Snitow }\end{array}$} & \multicolumn{2}{|c|}{ 8. Performing Organization Report No. } \\
\hline \multirow{2}{*}{\multicolumn{3}{|c|}{$\begin{array}{l}\text { 9. Performing Organization Name and Address } \\
\text { Pacific Institute for Research and Evaluation } \\
\text { Calverton Office Park, } 11720 \text { Beltsville Drive, Suite } 900 \\
\text { Calverton, Maryland } 20705-3102 \\
\text { Phone: } 301-755-2700 \\
\text { Fax: } 301-755-2709\end{array}$}} & \\
\hline & & & \multicolumn{2}{|c|}{$\begin{array}{l}\text { 11. Contract or Grant No. } \\
\text { DTNH22-02-D-95121 } \\
\text { Task \#13 }\end{array}$} \\
\hline \multirow{2}{*}{\multicolumn{3}{|c|}{$\begin{array}{l}\text { 12. Sponsoring Agency Name and Address } \\
\text { Office of Behavioral Safety Research } \\
\text { National Highway Traffic Safety Administration } \\
1200 \text { New Jersey Avenue SE. } \\
\text { Washington, DC } 20590\end{array}$}} & \multicolumn{2}{|c|}{$\begin{array}{l}\text { 13. Type of Report and Period Covered } \\
\text { Final Report }\end{array}$} \\
\hline & & & \multicolumn{2}{|c|}{ 14. Sponsoring Agency Code } \\
\hline \multicolumn{5}{|l|}{ 15. Supplementary Notes } \\
\hline \multicolumn{5}{|c|}{$\begin{array}{l}\text { 16. Abstract } \\
\text { This report summarizes a study of the implementation of drug per se laws in } 15 \text { States. These laws generally make it an } \\
\text { impaired-driving offense to drive with a measurable amount of certain drugs in one's system. The specific prohibited } \\
\text { drugs vary by State. The laws are generally integrated into the States' overall impaired-driving statute. Though all } 15 \\
\text { States were studied to some degree, deeper study of the process was conducted in } 6 \text { States. This involved discussions } \\
\text { with government officials and law enforcement officers, and a series of structured discussions with prosecutors. This } \\
\text { study was not an impact evaluation of drug per se laws on crashes, but rather an attempt to gain an understanding of } \\
\text { how the drug per se laws are implemented and perceptions about the law of those charged with implementing the law. } \\
\text { It was initially intended that the study would also assess the effect of passing driving under the influence of drugs } \\
\text { (DUID) per se laws on the volume of DUID arrests and on conviction patterns, but data to directly address those issues } \\
\text { were not available. A general consensus among law enforcement officers we held discussions with was the adoption of } \\
\text { drug per se laws did not necessarily make enforcement easier, but did have a positive effect on prosecution. This } \\
\text { general perception was shared by prosecutors we interviewed. Because the drug per se laws have typically been } \\
\text { adopted as a component of States' impaired-driving statutes, one difficulty of this study was obtaining accurate data on } \\
\text { volume of arrests and conviction rates for the DUID component of the impaired-driving law was problematic. } \\
\text { Recommendations include developing a procedure where impaired-driving citations indicate drugs, alcohol, or both, but } \\
\text { also adopting procedures ensure information is integrated into computerized data systems of both law enforcement } \\
\text { agencies and courts. }\end{array}$} \\
\hline \multicolumn{2}{|c|}{$\begin{array}{l}\text { 17. Key Words } \\
\text { Drugs and driving, DUID, driving under the influence of } \\
\text { drugs, drugged driving, drug per se. }\end{array}$} & \multicolumn{3}{|c|}{$\begin{array}{l}\text { 18. Distribution Statement } \\
\text { Available from the National Technical Information Service } \\
\text { www.ntis.gov. }\end{array}$} \\
\hline $\begin{array}{l}19 \text { Security Classif. (of this report) } \\
\text { Unclassified }\end{array}$ & \begin{tabular}{l|l} 
20. Security Clas \\
Unclassifiec
\end{tabular} & this page) & \begin{tabular}{|l}
21 No. of Pages \\
204
\end{tabular} & 22. Price \\
\hline
\end{tabular}

Form DOT F 1700.7 (8/72) 


\section{Table of Contents}

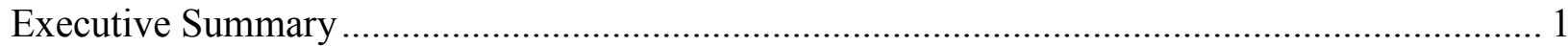

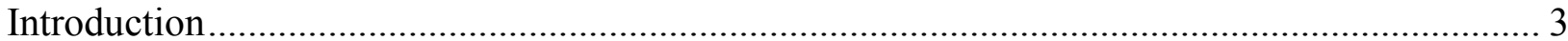

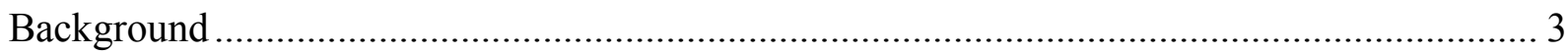

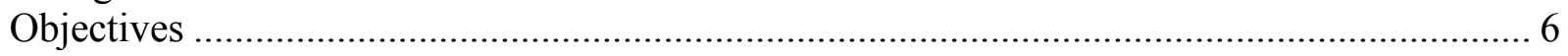

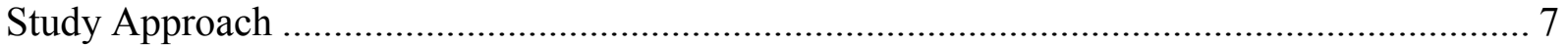

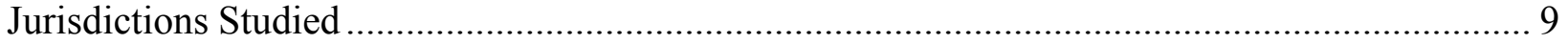

How This Report Is Organized ................................................................................. 10

Descriptions of Selected Study States........................................................................................... 11

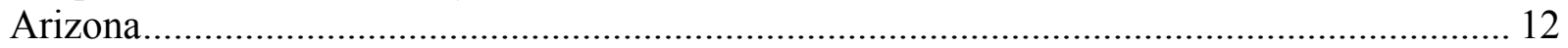

State With Drug Per Se Law and Active DRE Program................................................... 12

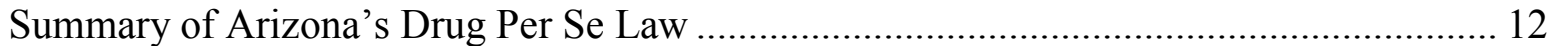

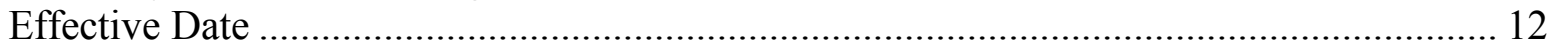

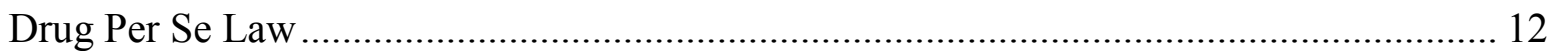

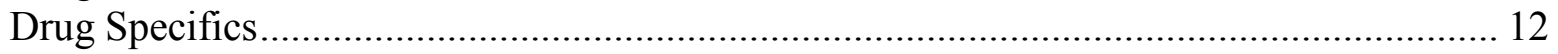

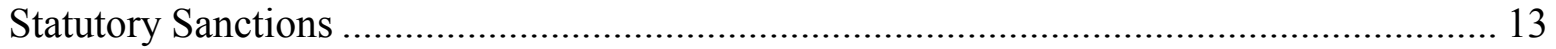

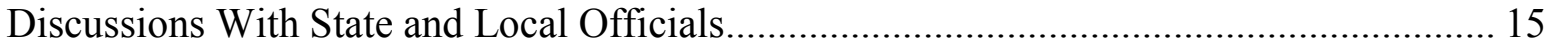

Summary of Law Enforcement Perspective ………………............................................ 16

Summary of Prosecutorial Perspective …………………........................................... 18

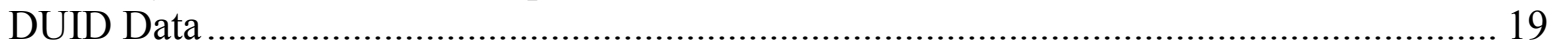

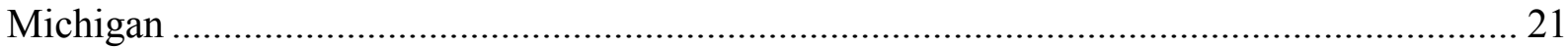

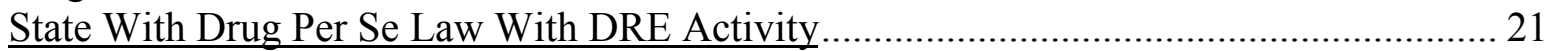

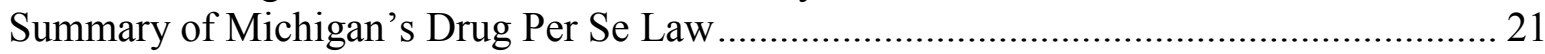

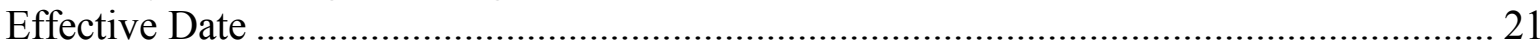

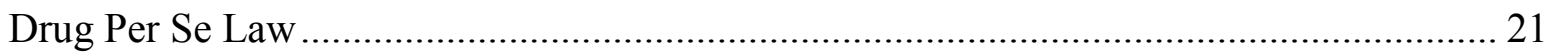

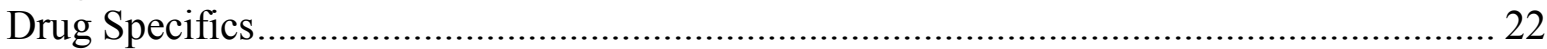

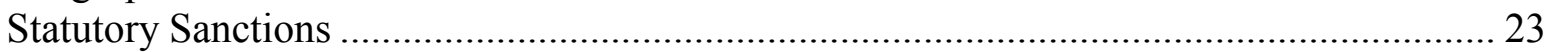

Implementation and Handling of Michigan's OWID Cases ............................................. 24

Discussions With State and Local Officials........................................................................ 25

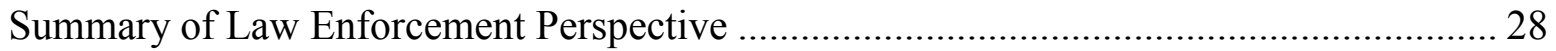

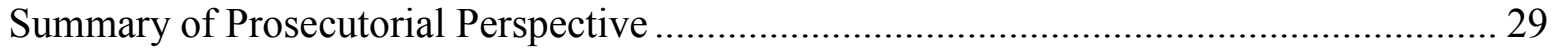

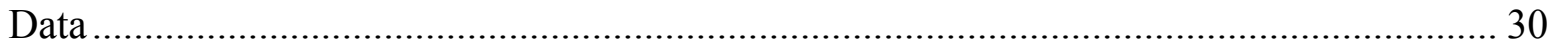

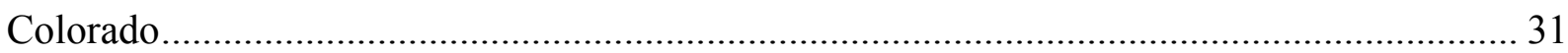

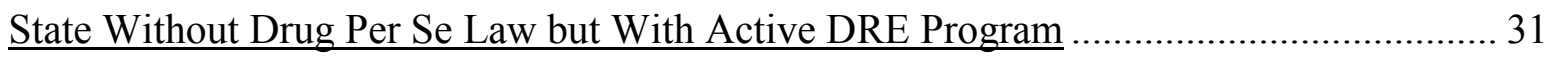

Summary of Colorado's Drug Law................................................................................. 31

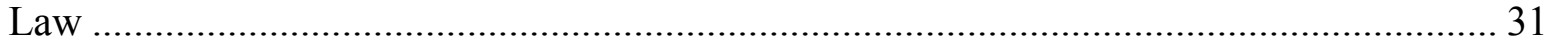

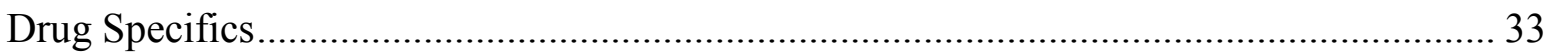

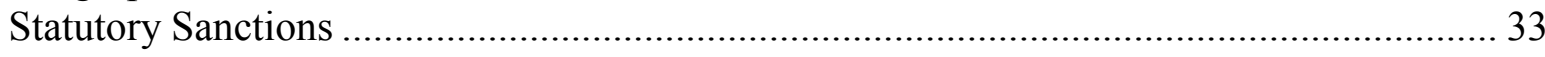

Implementation and Handling of Colorado's DUID Cases ................................................... 34

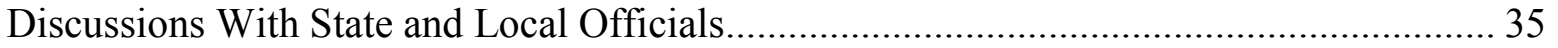

Summary of Law Enforcement Perspective ………….................................................... 36

Summary of Prosecutorial Perspective ………………....................................................... 37

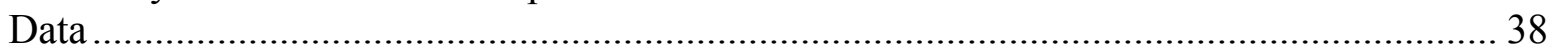

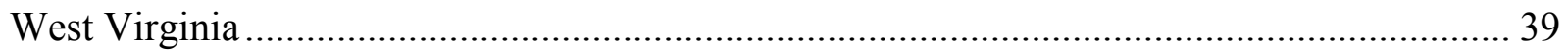


State Without Drug Per Se Law and Without DRE Program .............................................. 39

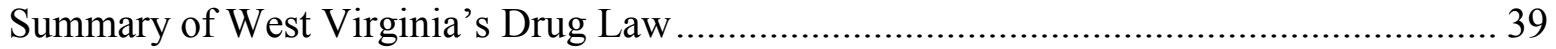

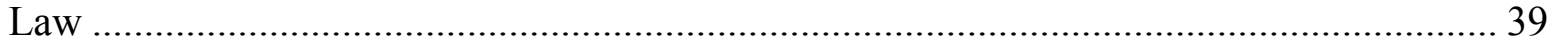

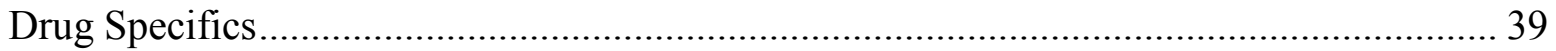

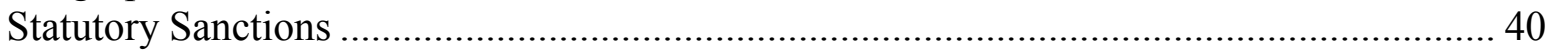

Implementation and Handling of West Virginia's DUID Cases ............................................ 41

Discussions With State and Local Officials....................................................................... 42

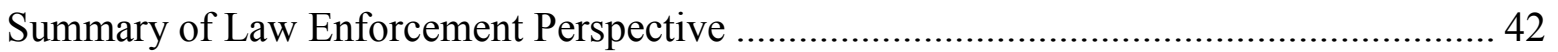

Summary of Prosecutorial Perspective ........................................................................ 43

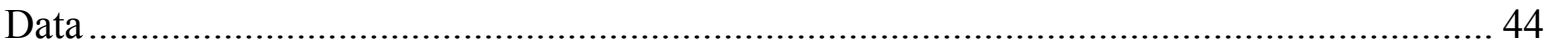

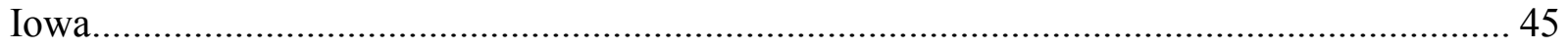

State With Drug Per Se Law and DRE Program .......................................................... 45

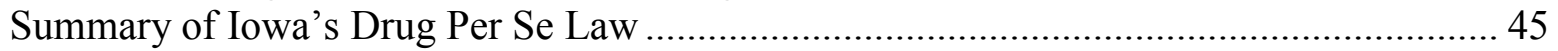

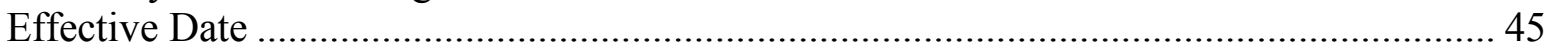

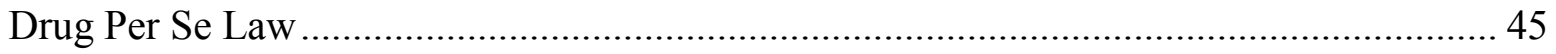

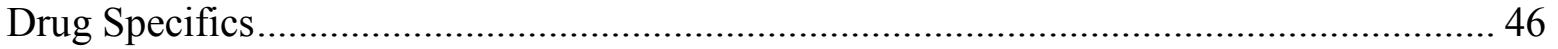

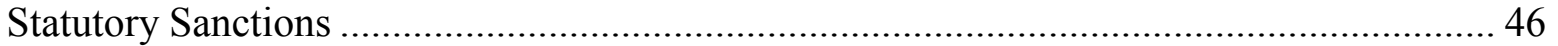

Implementation and Handling of Iowa's OWID Cases .................................................. 48

Discussions With State and Local Officials......................................................................... 49

Summary of Law Enforcement Perspective …………….................................................. 49

Summary of Prosecutorial Perspective …………….................................................. 50

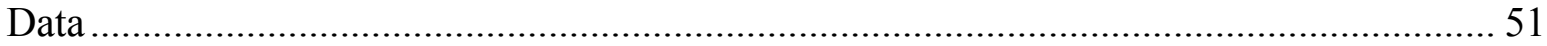

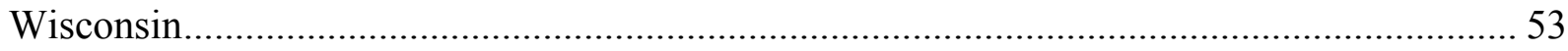

State With Drug Per Se Law and DRE Program …………............................................. 53

Summary of Wisconsin's Drug Per Se Law ..................................................................... 53

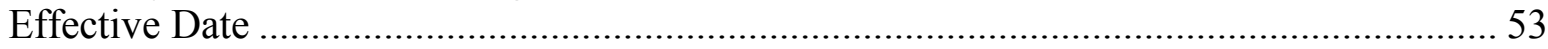

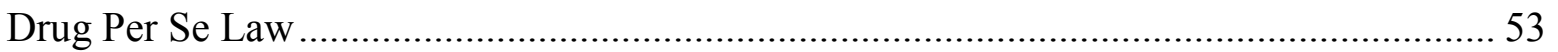

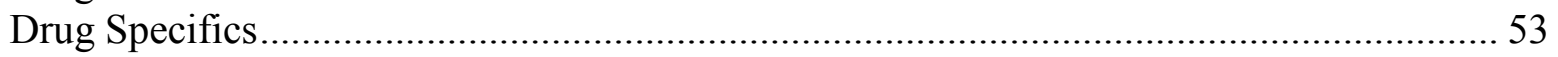

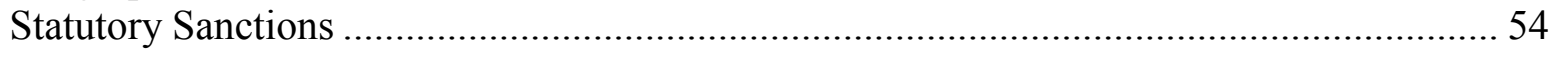

Implementation and Handling of Wisconsin's OUID Cases .............................................. 55

Summary of Law Enforcement Perspective …………….................................................... 56

Summary of Prosecutorial Perspective ……………........................................................ 57

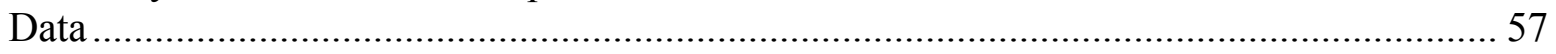

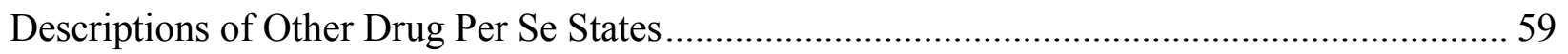

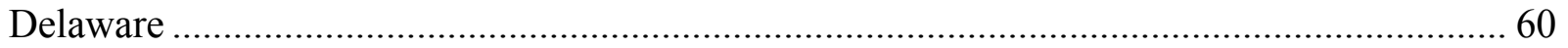

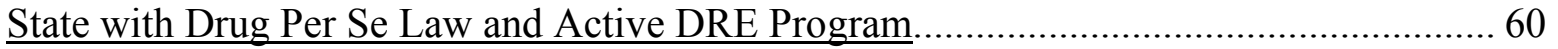

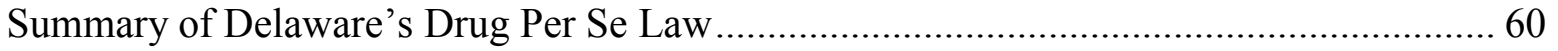

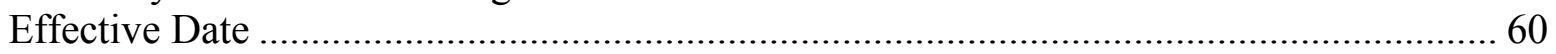

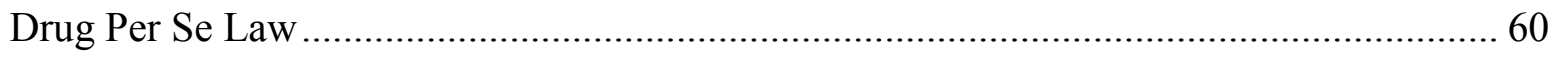

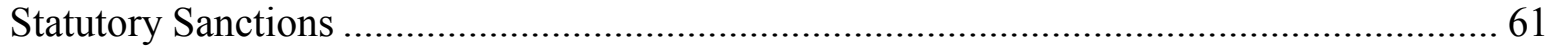

Implementation and Handling of Delaware's DUID Cases..................................................... 62

Data

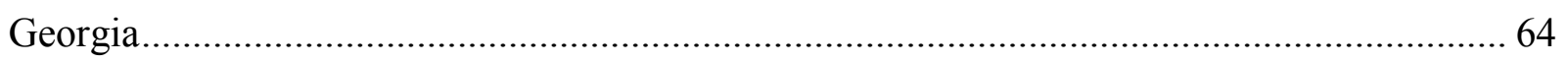

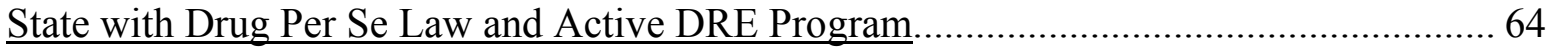

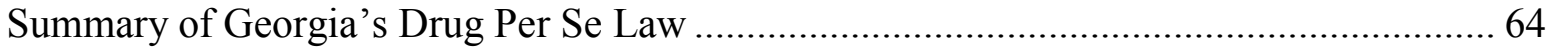

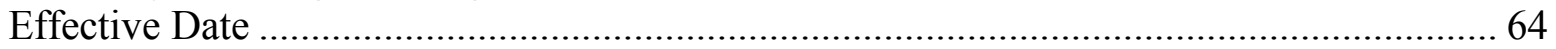




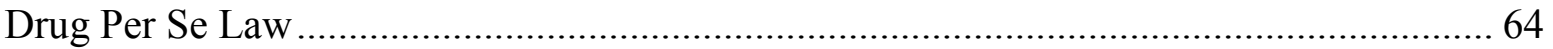

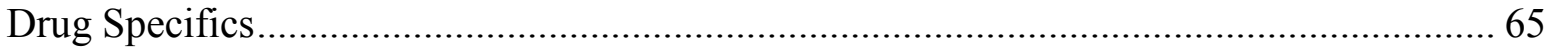

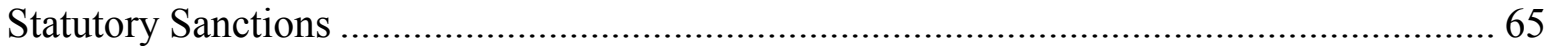

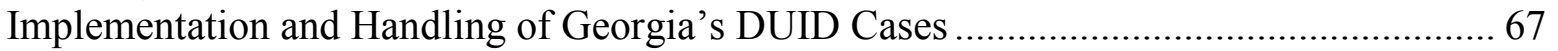

Data

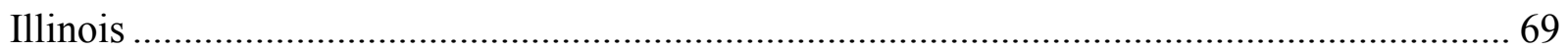

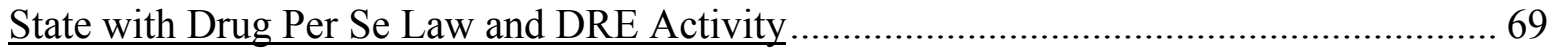

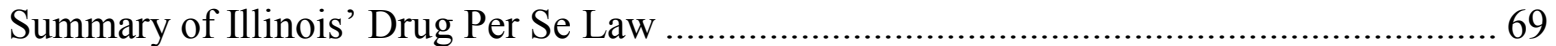

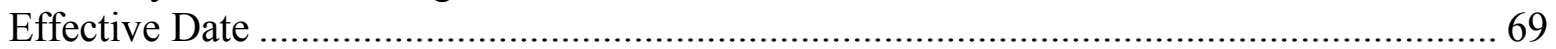

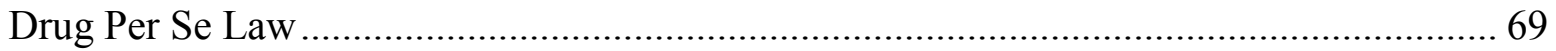

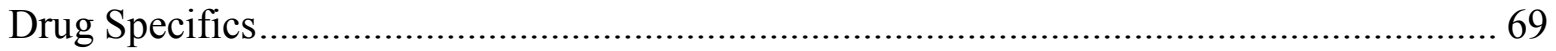

Implementation and Handling of Illinois’ DUID Cases …………….................................. 71

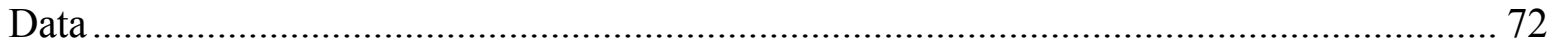

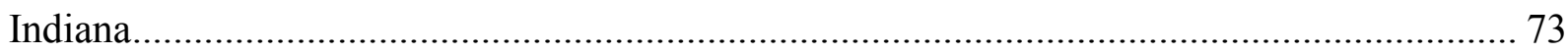

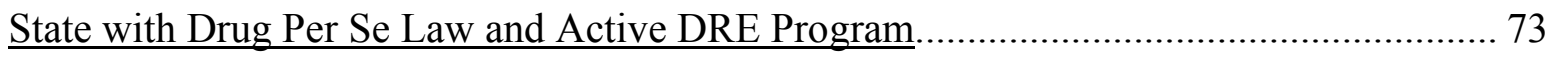

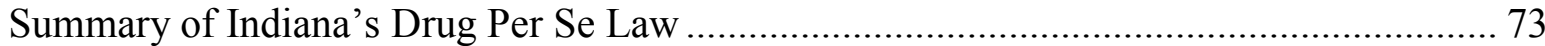

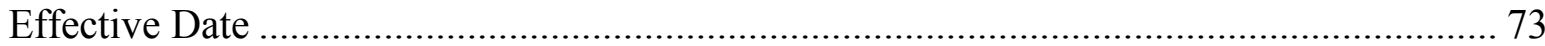

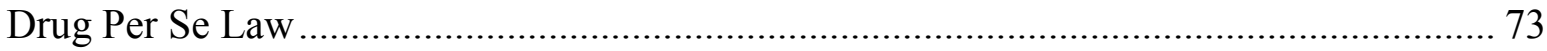

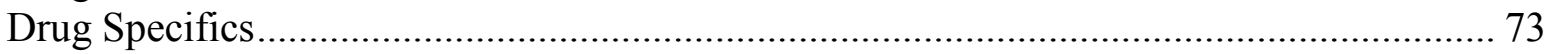

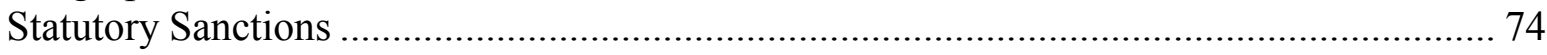

Implementation and Handling of Indiana's OWID Cases .................................................. 75

Data

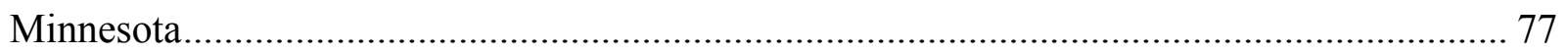

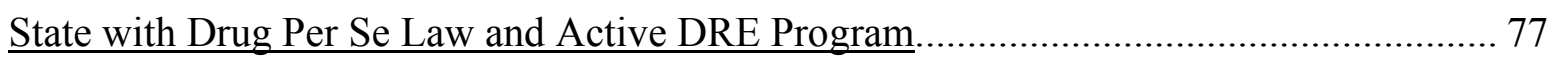

Summary of Minnesota's Drug Per Se Law ………....................................................... 77

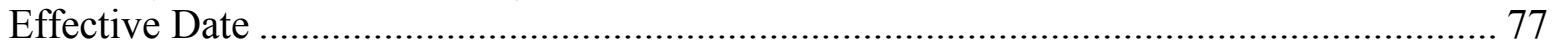

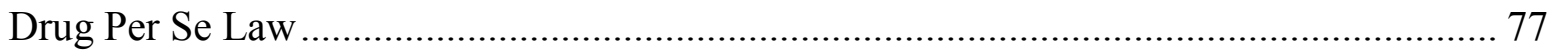

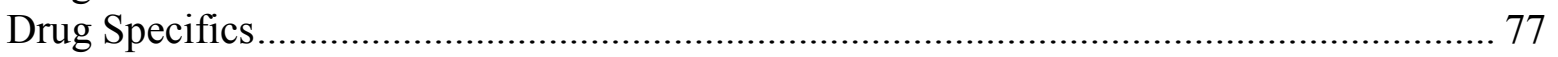

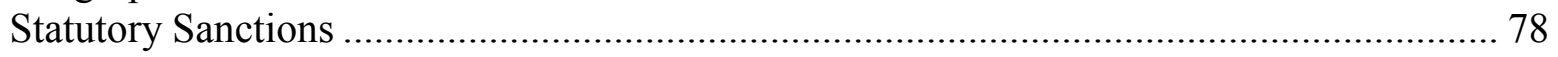

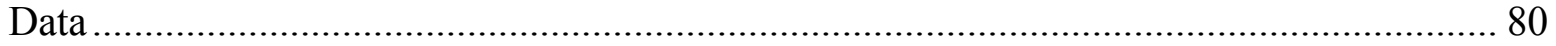

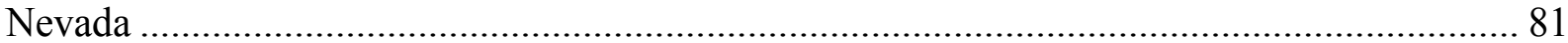

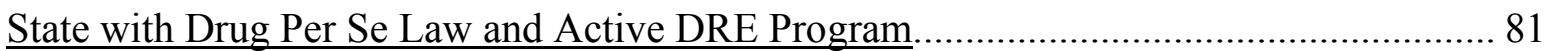

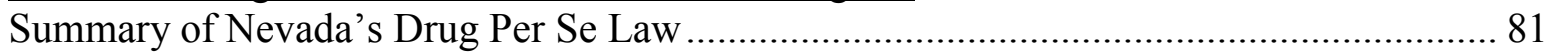

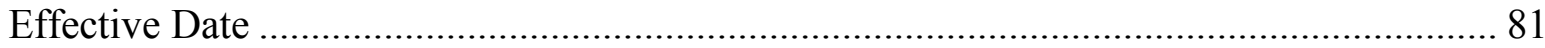

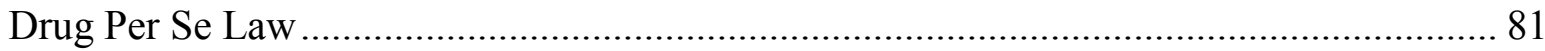

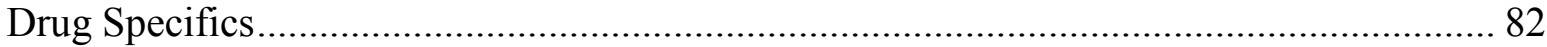

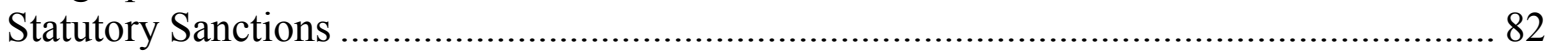

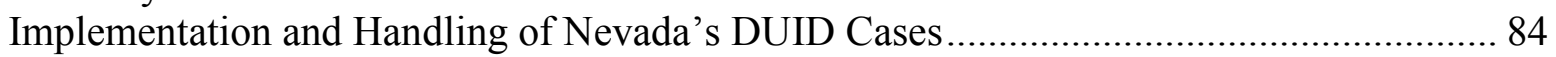

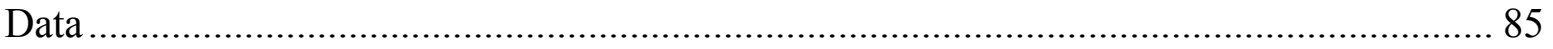

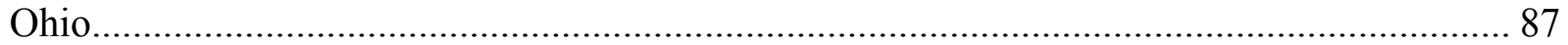

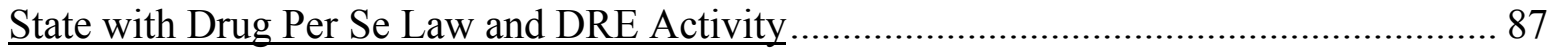

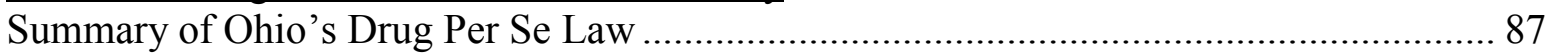

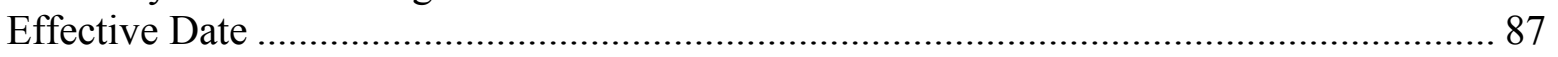

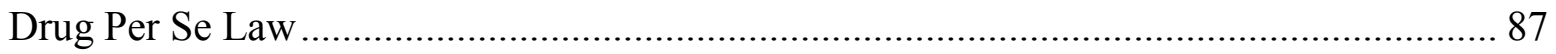

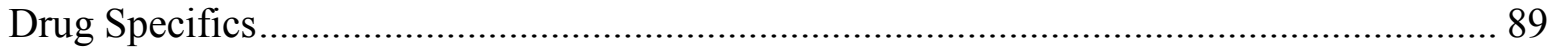

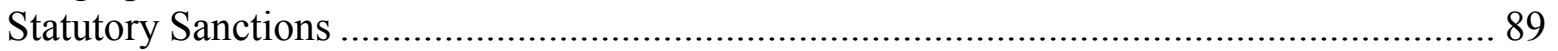


Implementation and Handling of Ohio's OUID Cases ............................................. 91

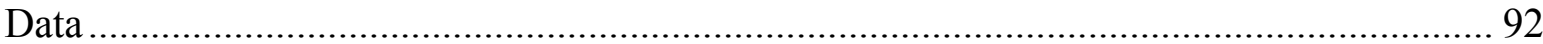

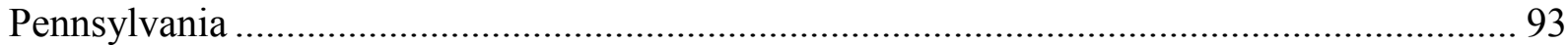

State With Drug Per Se Law and Active DRE Program................................................ 93

Summary of Pennsylvania's Drug Per Se Law ................................................................. 93

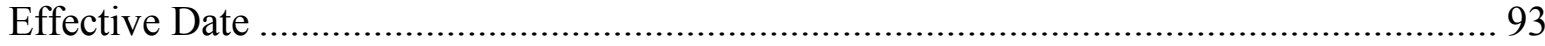

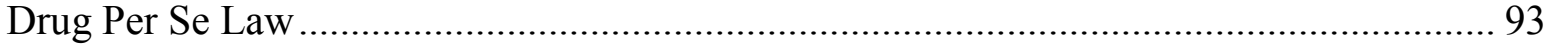

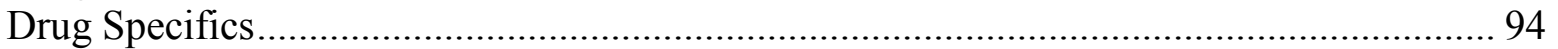

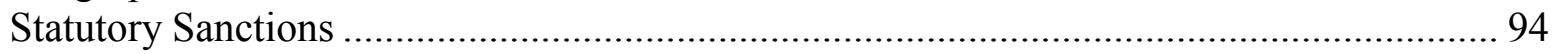

Implementation and Handling of Pennsylvania's DUID Cases...................................... 96

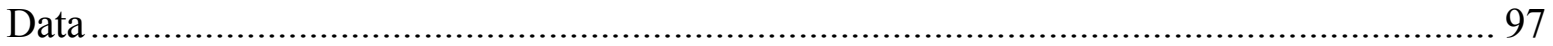

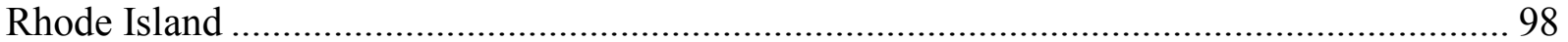

State with Drug Per Se Law and Active DRE Program.................................................. 98

Summary of Rhode Island's Drug Per Se Law .............................................................. 98

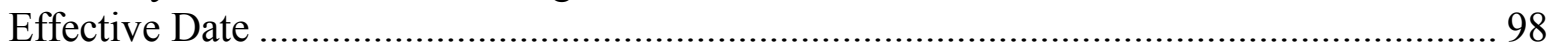

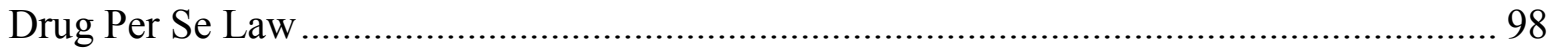

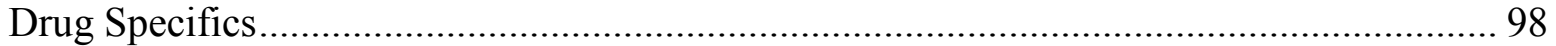

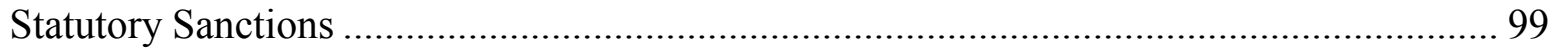

Implementation and Handling of Rhode Island's DUID Cases .................................... 100

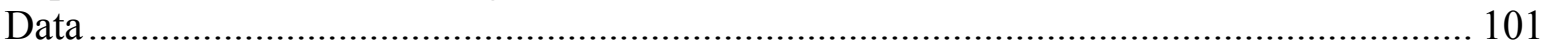

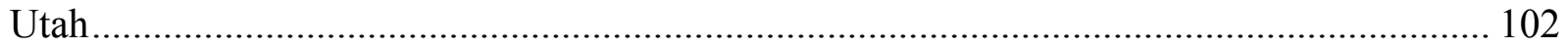

State With Drug Per Se Law and Active DRE Program............................................. 102

Summary of Utah's Drug Per Se Law ...................................................................... 102

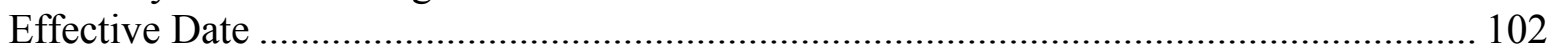

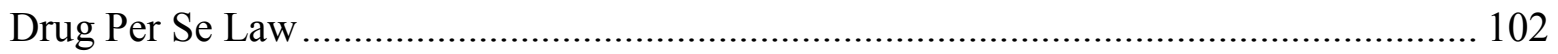

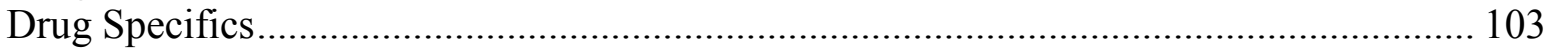

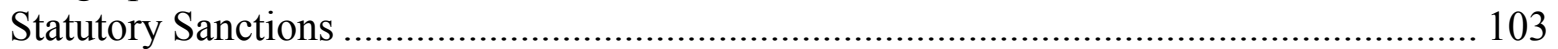

Implementation and Handling of Utah's DUID Cases ............................................. 105

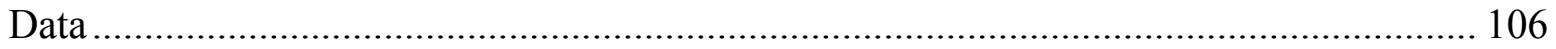

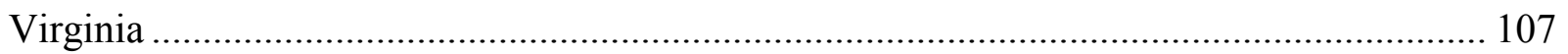

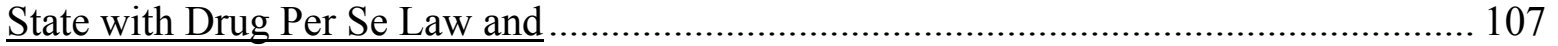

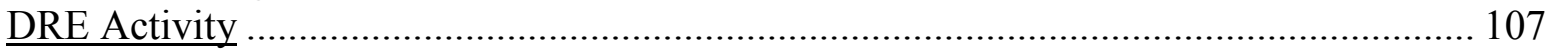

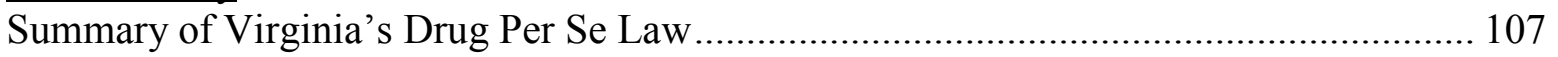

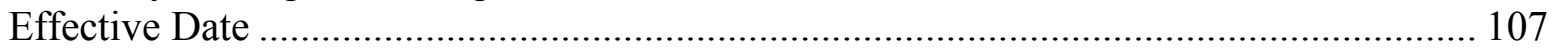

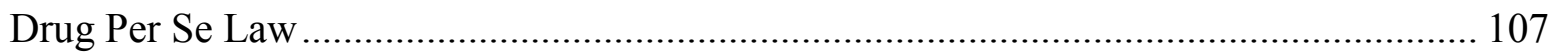

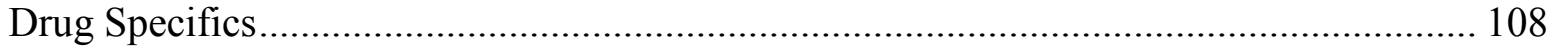

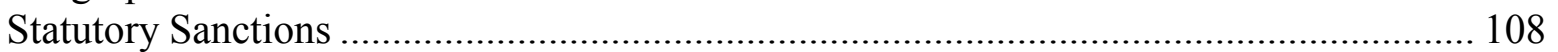

Implementation and Handling of Virginia's DUID Cases.......................................... 109

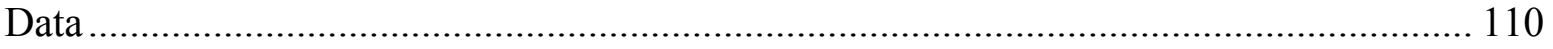

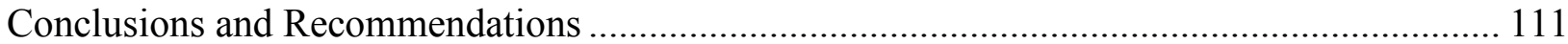

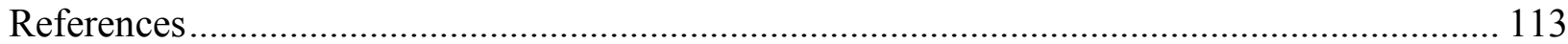

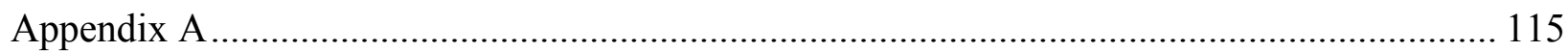

Questions for Structured Discussions with Prosecutors and Judges................................. 115

Questions for Structured Discussions with Law Enforcement ......................................... 118

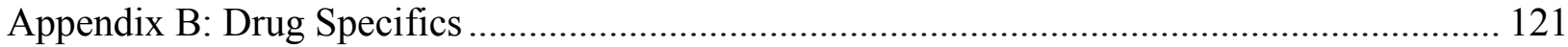

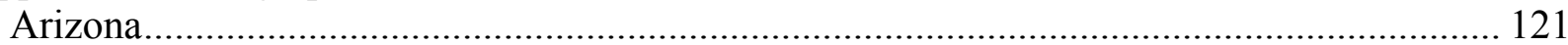




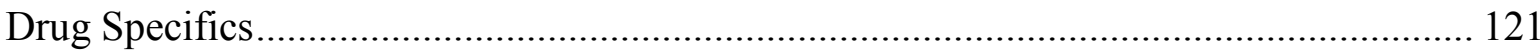

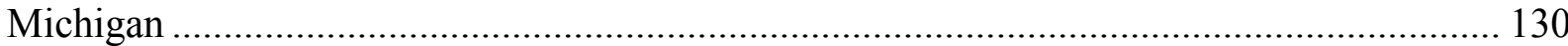

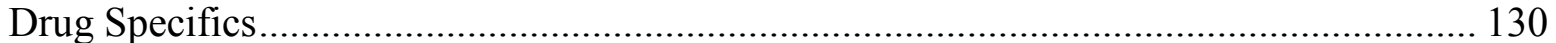

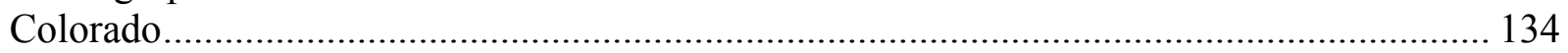

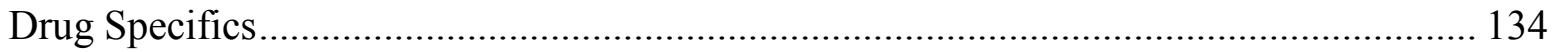

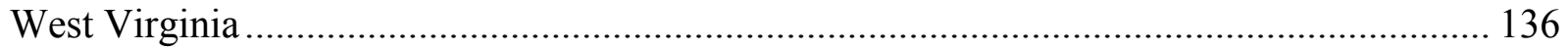

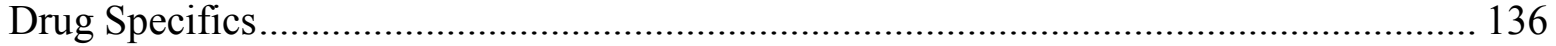

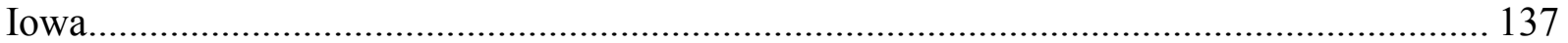

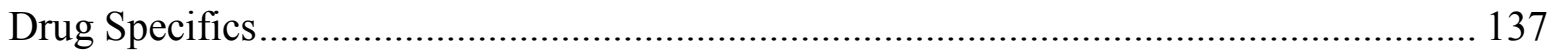

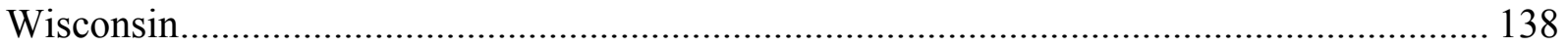

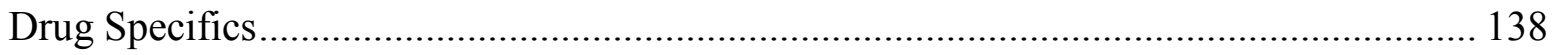

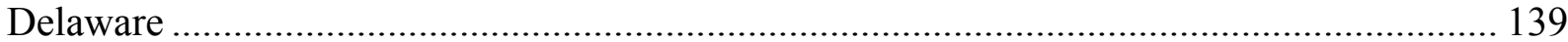

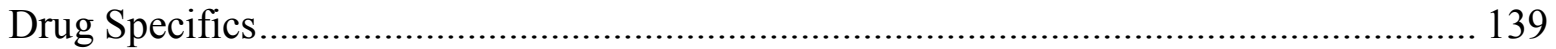

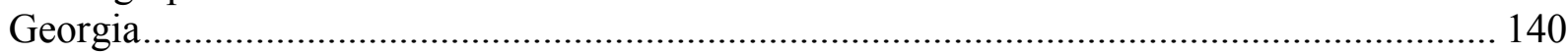

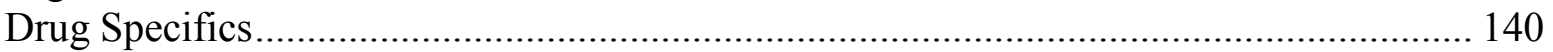

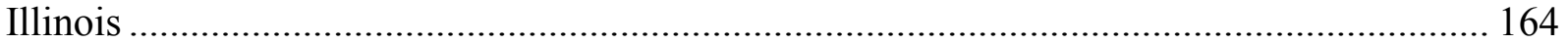

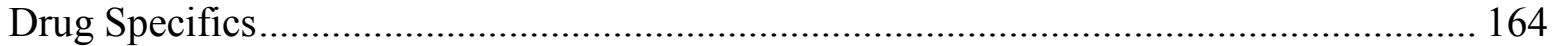

Indiana

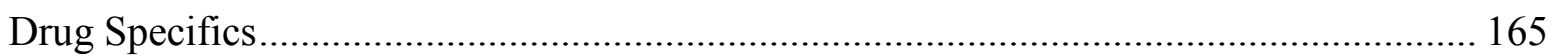

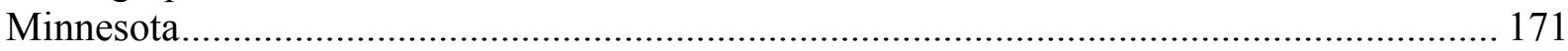

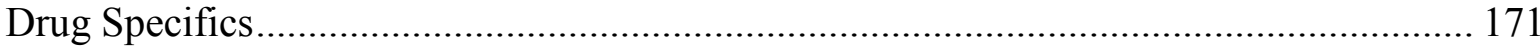

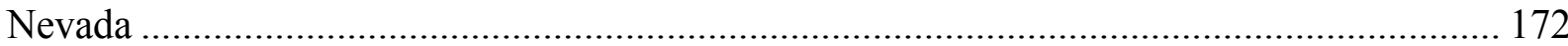

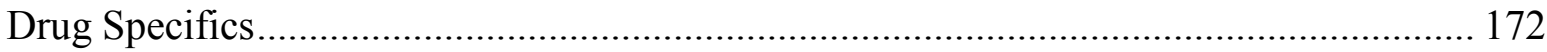

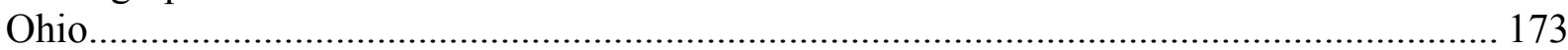

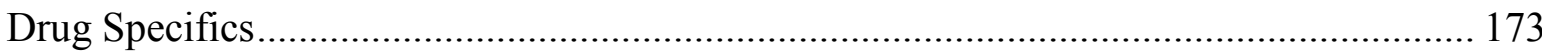

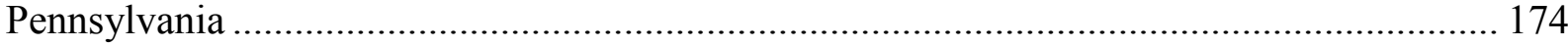

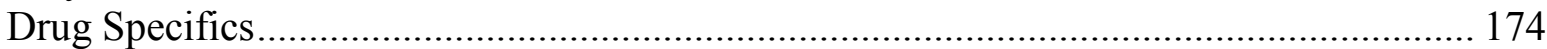

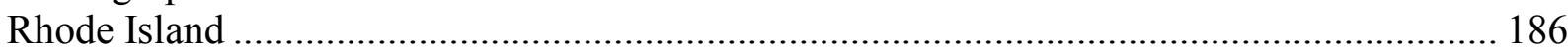

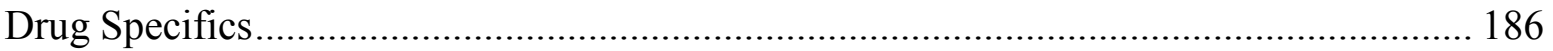

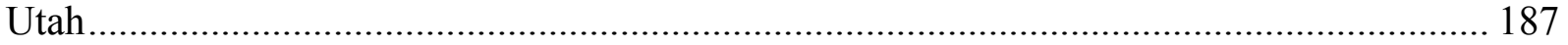

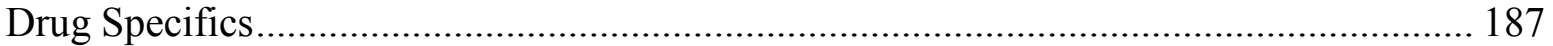

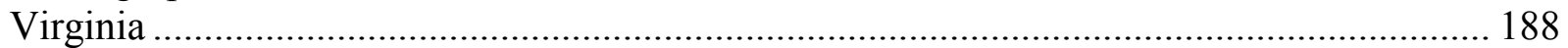

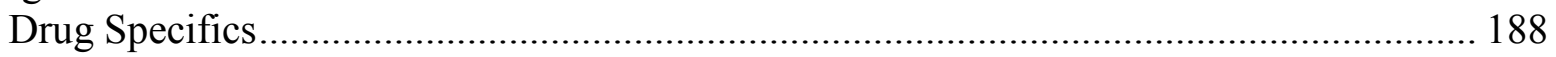

\section{List of Tables}

Table 1. States With Drug Per Se Laws and Effective Dates ...................................................... 6

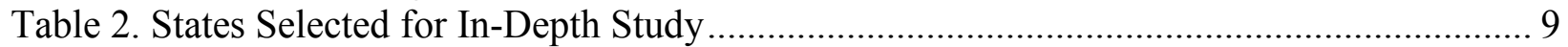

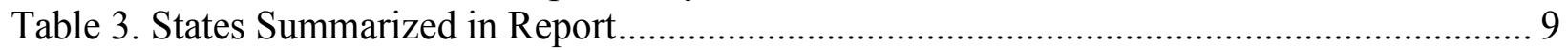

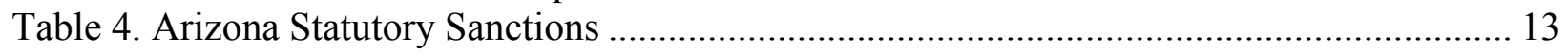

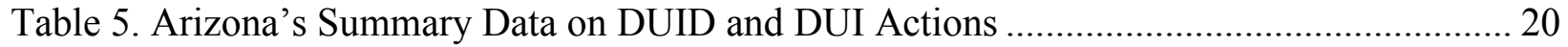

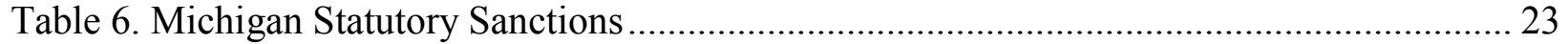

Table 7. Michigan's Summary Data on OWPD and OWI Actions ............................................ 30

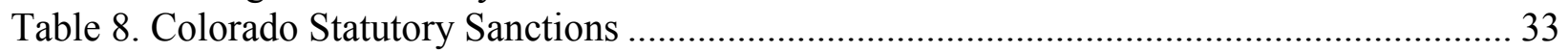

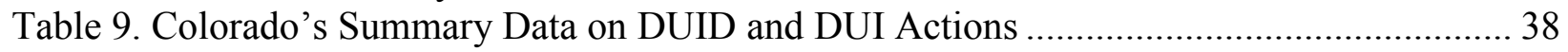

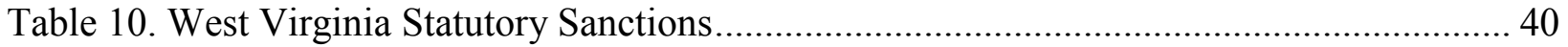

Table 11. West Virginia's Summary Data on DUID and DUI Actions........................................ 44 
Table 12. Iowa Statutory Sanctions ................................................................................ 46

Table 13. Iowa's Summary Data on OWID and OWID Actions ........................................... 52

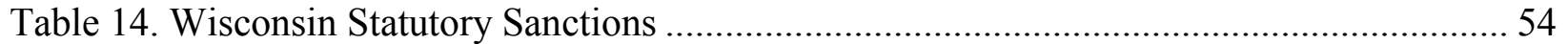

Table 15. Wisconsin's Summary Data on OUID and OUI Actions ........................................ 58

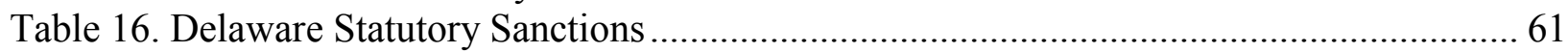

Table 17. Delaware's Summary Data on DUID and DUI-A Actions..................................... 63

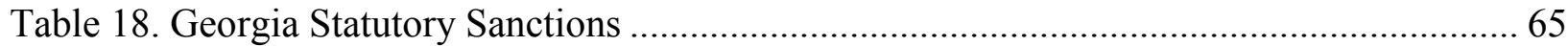

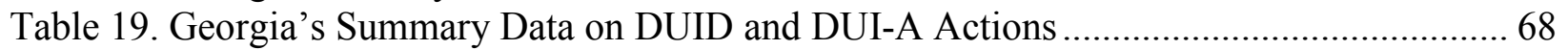

Table 20. Illinois Statutory Sanctions ............................................................................... 70

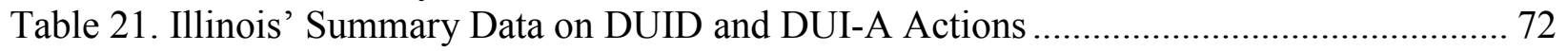

Table 22. Indiana Statutory Sanctions .............................................................................. 74

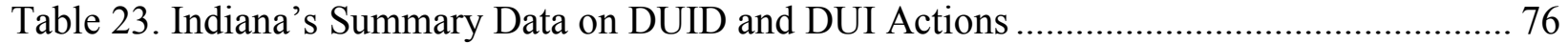

Table 24. Minnesota Statutory Sanctions ............................................................................... 78

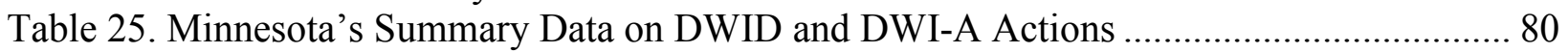

Table 26. Nevada Statutory Sanctions ................................................................................ 82

Table 27. Nevada's Summary Data on DUID and DUI-A Actions....................................... 85

Table 28. Las Vegas, Nevada's Summary Data on DUID and DUI-A Actions....................... 85

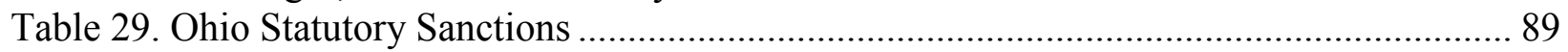

Table 30. Ohio's Summary Data on OUID and OUI Actions ............................................... 92

Table 31. Pennsylvania Statutory Sanctions .......................................................................... 94

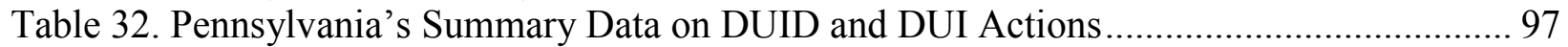

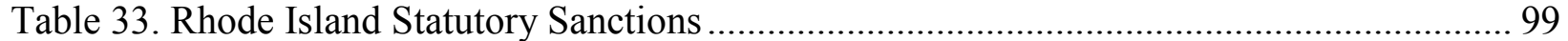

Table 34. Rhode Island's Summary Data on DUID and DUI-A Actions.............................. 101

Table 35. Utah Statutory Sanctions .................................................................................. 103

Table 36. Utah's Summary Data on DUID and DUI-A Actions ......................................... 106

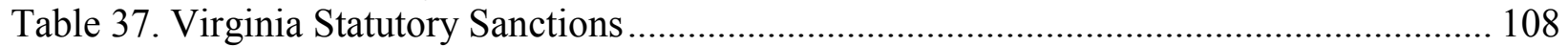

Table 38. Virginia's Summary Data on DUID and DWI Actions ........................................ 110

\section{List of Figures}

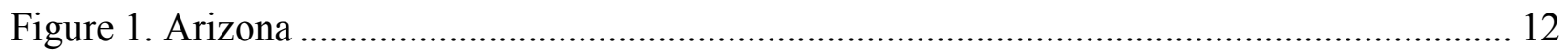

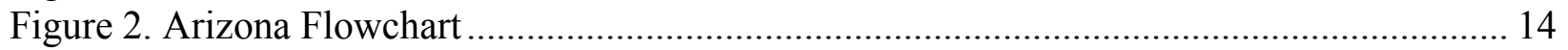

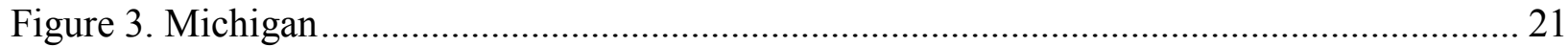

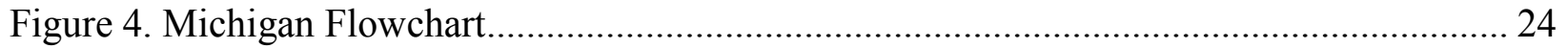

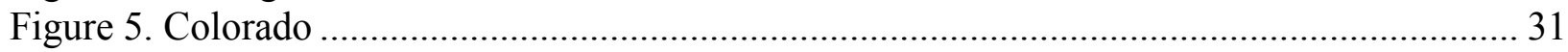

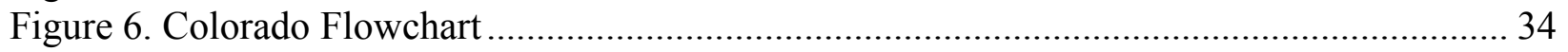

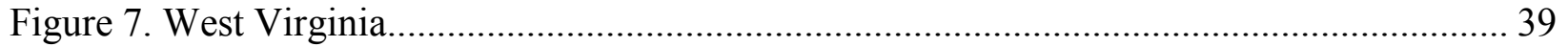

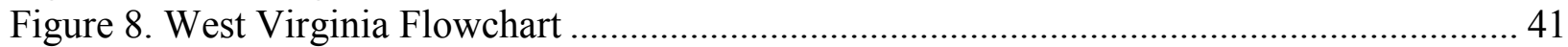

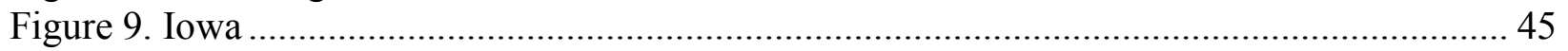

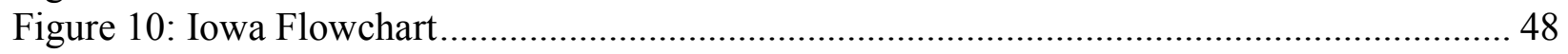

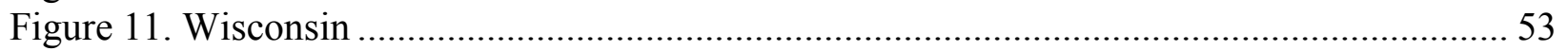

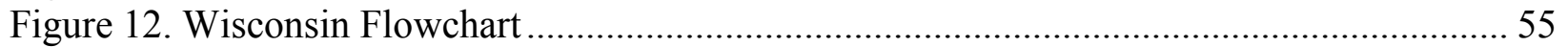

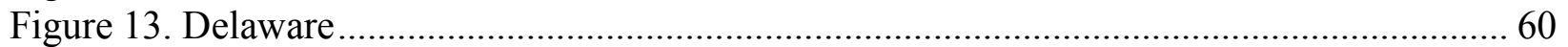

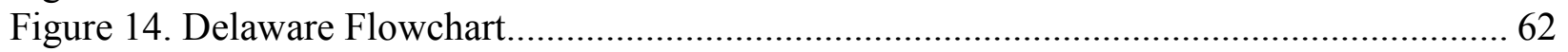

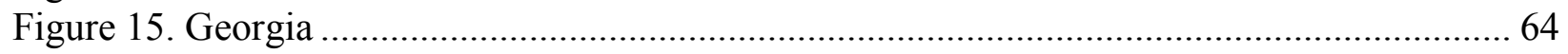

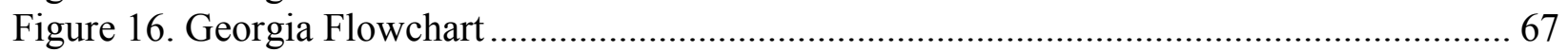

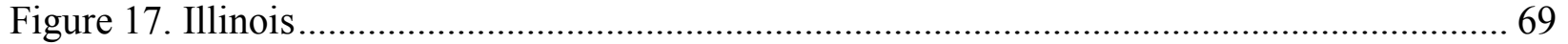




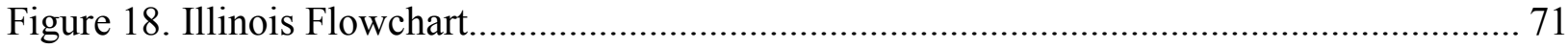

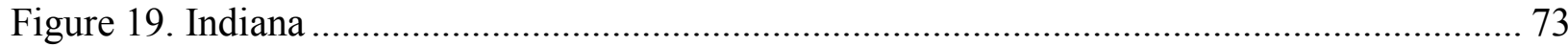

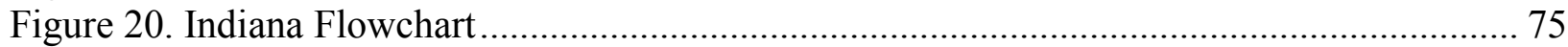

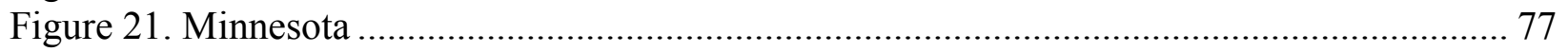

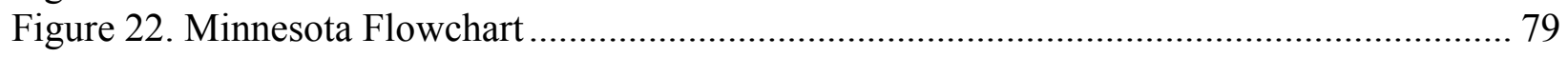

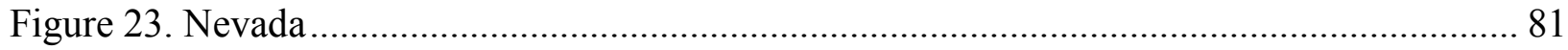

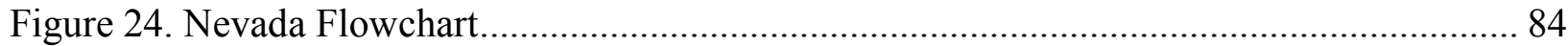

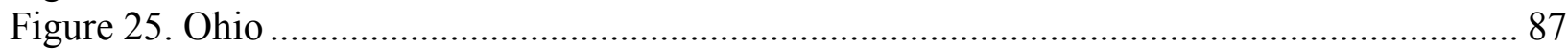

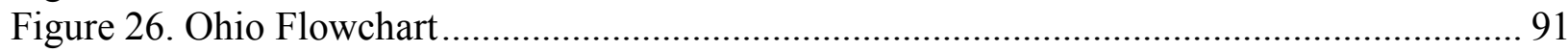

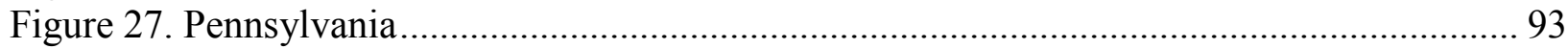

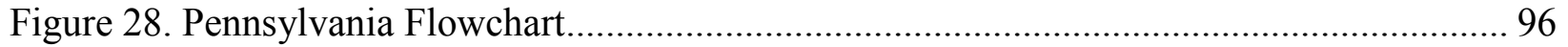

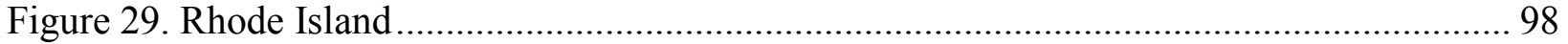

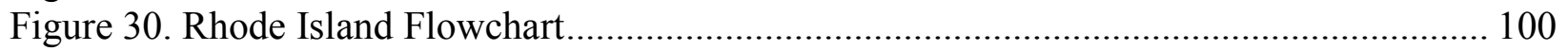

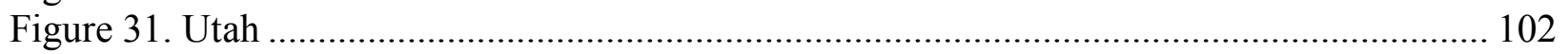

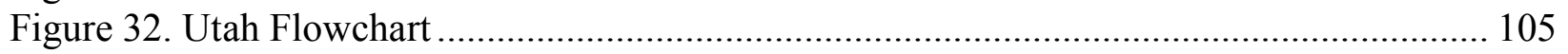

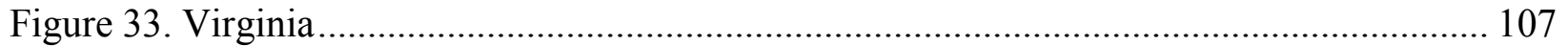

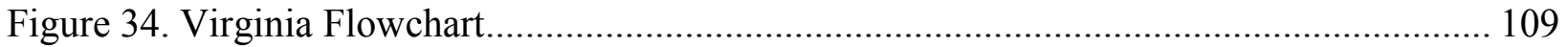




\section{Acknowledgements}

Many people helped us in the conduct of this project, but our principle contacts in each of the States where we conducted site visits were particularly helpful. They include:

- Dan Mulleneaux, Drug Recognition Expert (DRE) Coordinator, Arizona Governor's Office of Highway Safety

- Glenn Davis, DRE Coordinator, Colorado Governor's Highway Safety Program

- Denny Becker, Drug Evaluation and Classification (DEC) Program Manager, Iowa Governor's Traffic Safety Bureau

- J. Michael Laski, Director, Iowa Governor's Traffic Safety Bureau

- Jason Hamblin, Alcohol Program Coordinator, Michigan Office of Highway Safety Planning

- Bob Tipton, Coordinator, West Virginia Governor's Highway Safety Program

- J.D. Meadows, Law Enforcement Liaison, West Virginia Governor's Highway Safety Program

- Dennis Hughes, Chief, Policy Analysis and Local Programs, Wisconsin Bureau of Transportation Safety

These people were essential to our gathering information in their States; however, many others including judges, prosecutors, law enforcement, and other government officials too numerous to name were extremely helpful in this process. 


\section{Executive Summary}

This report provides the results of a study of driving under the influence of drugs (DUID) laws and how they have been implemented in the United States. The primary focus of the study was to assess the effects of adopting drugged driving per se laws. The basic approach was through document reviews, telephone conversations, and site visits to learn about implementation procedures in States with different configurations of DUID laws and enforcement training, and to assess whether there were differences in arrest and disposition patterns attributable to those configurations.

Drug per se laws are not quite analogous to the alcohol impaired-driving per se laws now in effect in every State make it illegal to operate a motor vehicle with a blood alcohol concentration (BAC) of .08 grams per deciliter or greater. Alcohol-impaired driving per se laws are based on evidence that all drivers are impaired at .08 BAC. Drug per se laws are more analogous to zero-tolerance laws that make it illegal to drive with certain drugs in the system.

Currently, there are 15 States where it is illegal per se to operate a motor vehicle with certain drugs in one's system.

Three of those States (Nevada, Ohio, and Virginia) have determined that driving with specific cutoff levels of certain prohibited drugs or substances other than alcohol is a per se violation of its DUI statute.

Of the 15 States, 12 States (Arizona, Delaware, Georgia, Illinois, Indiana, Iowa, Michigan, Minnesota, Pennsylvania, Rhode Island, Utah, and Wisconsin) do not tolerate any presence of a prohibited drug or substance in a driver's body while the person is driving. The specific drugs prohibited in these States vary (see Appendix B). In these States, any amount of prohibited drug found in the blood or urine of a driver while operating a motor vehicle is a per se violation of those States' DUI statutes. These States were the major focus of this study.

Additionally, in 5 States (California, Colorado, Idaho, Kansas, and West Virginia), it is illegal for any drug addict or habitual user of drugs to drive a vehicle in that State.

Two States (North Carolina and South Dakota) make it illegal for any people younger than 21 to drive with any amount of a prohibited drug or substance in their bodies.

The two main objectives of this study were:

- Determining the effects of drug per se laws in terms of DUID arrests and convictions.

- Determining the extent to which the laws are used, how the laws are being used, document any special concerns or problems, and describe how and if they have been resolved.

To determine whether drug per se laws have had any positive or negative impact on DUID arrests and convictions and to determine what factors (such as urine screening tests, Drug Evaluation and Classification [DEC] programs, etc.) may enhance the effectiveness of per se laws, we attempted to gather two broad categories of information. These include: (1) archival DUID arrest and conviction data, and (2) information through structured discussions and meetings with State and local officials, prosecutors, and law enforcement. 
In an effort to develop an understanding of the effects of having a drug per se law and how having a Drug Recognition Expert (DRE) program might relate to those effects, we visited States with and without drug per se laws and with and without DRE programs. This allowed us to obtain a balanced view of how DUID laws function.

Thus, we gathered more detailed information, including that obtained through structured discussions meetings, from 6 States. This included 3 States with a drug per se law and a strong DRE program (Arizona, Iowa, and Wisconsin), a State with a drug per se law and no DRE program (Michigan), a comparison State with a DRE program but no per se law (Colorado), and a State with neither (West Virginia).

Archival data we attempted to obtain consisted of records such as DUID arrests and convictions from local and State law enforcement and court agencies, and data on the number of DREs and the volume of cases in which they were engaged. We attempted to obtain data from two years prior to the implementation of the drug per se law through the present, for each. Because in virtually every State the DUID offense is unified under the basic impaired-driving statute, the information was not tracked completely separately in any of the data systems. Consequently, we had to rely primarily on anecdotal assessments of arrest and conviction patterns as developed from discussions with police and prosecutors because the lack of data made analysis of the effectiveness of the law impossible.

In the remaining drug per se States, we did not conduct site visits or structured discussions, but did summarize drug per se laws, effective dates, sanctions, drug specifics and implementation, and sought archival arrest and conviction data.

In general, the traffic safety professionals we contacted in drug per se States were supportive in having the drug per se provision in their impaired-driving law. Though law enforcement officers generally said the per se feature of the law did not appreciably change the actual enforcement process in terms of the actions they performed to make a DUID arrest, they felt the provision did make it more likely such cases would be successfully prosecuted. In general, prosecutors we had discussions with echoed those sentiments.

A difficulty encountered in obtaining objective evidence of the effectiveness of DUID per se laws was the paucity of data to substantiate the opinions expressed by the professionals with whom we had discussions. The DUID per se offense is typically incorporated into the overall impaired-driving statute and thus is, generally, the same basic offense as the alcohol-related offense. Additionally, in many instances, offenders may have consumed both alcohol and drugs and the conviction may be based on evidence of one, the other, or both. Court and State driver records systems tend not to distinguish, or make narrow distinctions, between the various charging reasons and even less so among the elements of evidence leading to the disposition. Where limited records were available, the trend appears to be that adopting a DUID per se law was a positive change that facilitated the enforcement and prosecution of drug-impaired driving offenders.

A strong recommendation is that States consider refining their data collection and reporting systems to allow them to distinguish between the different categories of impaired-driving offenses. Another recommendation is that States adopt procedures that ensure information is integrated into computerized data systems of both law enforcement agencies and courts. Together, these two recommendations can help States more effectively monitor changes in this very important public safety area. 


\section{Introduction}

This report provides the results of a study of driving under the influence of drugs (DUID) laws and how they have been implemented in the United States. The primary focus of the study was to assess the effects of adopting drugged driving per se laws. The basic approach was through document reviews, telephone conversations and site visits to learn about implementation procedures in States with different configurations of DUID laws and enforcement training, and to assess whether there were differences in arrest and disposition patterns attributable to those configurations.

\section{Background}

Although the objective evidence supporting drugs as increasing crash risk is less compelling than for alcohol (Moskowitz, 2006), in part because sound epidemiologic risk studies have not been conducted there has been a growing call, particularly from the law enforcement community, for more effective legal tools to combat drugged driving. In recent discussions we have had with officers in this study, they report an increasing number of drivers who are stopped because of erratic driving who show impairment but have very low or zero blood alcohol concentrations. Many of these officers believe these drivers are impaired by other drugs, but feel they do not have sufficient legal tools to gain convictions for DUID. The current legal framework for DUID is similar to what it was for alcohol in the early 1970s when laws making it illegal per se to operate a motor vehicle with a BAC above a certain level were first being enacted.

In recent years, there has been ever increasing interest in drug-impaired driving and its effective detection and prosecution. In the early 1980's, the National Highway Traffic Safety Administration developed the Drug Evaluation and Classification (DEC) program based on the Los Angeles Police Department's Drug Recognition Expert (DRE) program. This extensive training and certification program taught officers signs and symptoms of drug impairment that could be used to determine drug use and associate it with specific categories of drugs. This program was intended to help develop evidence of impairment and guide analyses of biological specimens when looking for the presence of drugs other than alcohol in impaired drivers, particularly those with low BACs. Field evaluations of the program have generally found it to be effective in determining drug impairment, but have also indicated evaluations are not conducted as frequently as might be desired (Compton, 1986; Preusser et al., 1992). The determination of impairment, along with evidence of the presence of drugs from laboratory tests, is used to bring charges of drug-impaired driving. Because many drugs are illegal, a natural extension of this principle might be to make it an offense per se to have certain drugs in one's system while driving. In that case, the burden of proof would be reduced to having probable cause to make the traffic stop, reasonable suspicion the driver had ingested drugs, and proof drugs were present in the driver's system. This is not quite analogous to the alcohol-impaired driving per se laws now in effect in every State that make it illegal to operate a motor vehicle with a BAC of .08 or greater. Alcohol-impaired driving per se laws are based on evidence that all drivers are impaired at .08 BAC. Drug per se laws are more analogous to zero tolerance laws that make it illegal to drive with certain drugs in the driver's system. They are also similar to zero tolerance laws for youth, which prohibit driving with a positive BAC for a person under 21 years old. 
The evolution of the elements defining the alcohol-impaired driving offense can be instructive in developing an understanding of the potential refinement of factors defining the driving under the DUID offense.

In the United States, the drunk-driving offense initially was defined in behavioral terms. The initial basis of the offense was the arresting officer's testimony a person was driving erratically and, upon being stopped, displayed drunkenness. Blood alcohol test results are now also used as evidence to support the contention the drinking driver was under the influence.

With the epidemiological evidence of the increased risk of crash involvement associated with increased driver BACs emanating from studies such as those by Holcomb (1938) and Borkenstein et al. (1964), the rationale was developed for setting presumptive and then per se levels defining the alcohol-impaired driving offense. Presumptive levels provide that the offender is presumed guilty if the driver's BAC is greater than a prescribed level, but the defendant may offer a defense that the defendant was not impaired at that level. In the late 1960s and early 1970s, States began adopting per se laws that defined the offense in terms of the BAC level. Under these laws, a defendant is guilty per se, in and of itself, of the drunk-driving offense if the defendant's BAC is at or greater than that level. Thus, the argument that the defendant was not impaired should fall on deaf ears. In practice, however, having a BAC higher than the per se level is not a guarantee of conviction, but per se laws have resulted in increased conviction rates and have helped to deter drinking and driving (Peck, 1987). Tippetts et al. (2005), in an analysis of data from 19 States, also found alcohol per se laws effective in deterring impaired driving. These findings provided some of the impetus for some States to consider similar per se laws for drugs other than alcohol.

Many advances in knowledge about the effects of alcohol on highway safety and increases in the effectiveness of driving under the influence (DUI) enforcement can be attributed to the advent of reliable, accurate, noninvasive measurement of human alcohol levels through breath-test technology. The development of the Standardized Field Sobriety Testing (SFST) program also has assisted in enhancing enforcement of these laws.

Relative to alcohol-impaired driving, both the level of scientific knowledge and the evolution of the U.S. legal framework are in early stages for drug-impaired driving. Experimental laboratory studies and closed course driving studies have detected adverse effects on skills related to driving on a wide variety of drugs (Compton, 1985).

Epidemiological research on crash involvement has been much more limited and yielded more controversial results. The frequently cited Terhune study (1992) of fatally injured drivers used a responsibility analysis technique. It found no increased crash risk associated with marijuana or cocaine alone, but multiple drug use and the use of drugs in combination with alcohol seemed to be associated with increased crash risk. Mathijssen et al. (2002) recently reported on a casecontrol study conducted in the Netherlands; preliminary results indicate an increased risk for benzodiazepines, alcohol, and combinations of drugs, but no increased risk for single drug use for other classes of drugs. Dussault et al. (2002) also used a case-control approach to study crashes in Quebec; preliminary results indicated increases in risk associated with several categories of drugs, including cannabis. Poly-drug use generally was associated with increased risk. Recently, several studies have been published offering a stronger argument for increased crash risk due to drugs other than benzodiazepines. For example, Walsh, De Gier, Christopherson, \& Verstraete (2004) examined several studies and found several other drugs 
represent a risk to traffic safety. These drugs included opioids, especially for patients with no drug use experience; amphetamines, cocaine, and other stimulant drugs, at least in high doses; cannabis use, at least for the first few hours after use; and some antidepressants, specifically tricyclic antidepressants used during early treatment periods.

Fifteen States have per se laws regarding DUID for all drivers. Three of those States (Nevada, Ohio, and Virginia) have determined that driving with specific cutoff levels of certain prohibited drugs or substances other than alcohol is a per se violation of its DUI statute.

Of these 15 States, 12 (Arizona, Delaware, Georgia, Illinois, Indiana, Iowa, Michigan, Minnesota, Pennsylvania, Rhode Island, Utah, and Wisconsin) do not tolerate any presence of a prohibited drug or substance in a driver's body while driving. The specific drugs prohibited in these States vary (see Appendix B). In these States, any amount of prohibited drug found in the blood or urine of a driver while operating a motor vehicle is a per se violation of that States' DUI statutes. These States were the major focus of this study.

Two States (North Carolina and South Dakota) make it illegal for anyone younger than 21 to drive with any amount of a prohibited drug or substance in their bodies.

Additionally, in 5 States (California, Colorado, Idaho, Kansas, and West Virginia), it is illegal for any drug addicts or habitual users of drugs to drive vehicles in their States.

In most of these per se States, the compelling argument for adoption of the drug per se statute was that, prior to the laws, a driver was far less likely to be prosecuted for impaired driving if he/she were under the influence of an illegal substance than if he/she were under the influence of a legal substance (alcohol). This dilemma existed because there was a per se level for alcohol but no practical or legal way to establish an impairment-linked per se level for controlled substances. The per se approach creates an important legal distinction between having to prove a nexus between the observed driver impairment and drug use (causal relationship) and simply demonstrating observed impaired-driving behavior was associated with specified concentrations of drug/metabolite in the individual's body while operating the motor vehicle. In essence, the per se drug statute attempts to remedy the inconsistency of dealing with alcohol and other drugs by making the per se drug limit any amount of a controlled substance, and by making this offense equivalent to the per se alcohol offense. Some officials from the States with per se statutes have indicated that the statutes are working well, but to date there are no scientific studies to demonstrate their effectiveness. An objective of this project was to seek the necessary data to objectively address this question.

Evidence-gathering technology for drugs is not as advanced in terms of ease of use and noninvasiveness as it is for alcohol. Until recently, no simple test police officers could administer to obtain an indication of drug use similar to the preliminary breath test for alcohol has been available. Rather, samples of urine or blood typically must be sent away for laboratory analysis to determine the presence of drugs and their quantification. Screening tests using urine, which can be used by officers in the police station, have been field tested by NHTSA. The technology is also developing for using saliva, sweat, and hair samples to detect drug use (Hersch, Crouch, \& Cook, 2000).

As said earlier, NHTSA has funded the Drug Evaluation and Classification (DEC) program, which equips specially trained officers, known as Drug Recognition Experts (DREs), to observe and record behavioral evidence of drug use to assess potential drug impairment among persons 
suspected of drug-impaired driving, and guide chemical testing and expert testimony for DUID trials. Currently, more than 40 States have officially adopted DEC programs to train DRE personnel.

Drug per se laws, analogous to illegal per se laws for alcohol, are a relatively new phenomenon in the United States. Arizona was the first State to adopt a drug per se law, in 1990, and Delaware was the most recent - the drug per se law went into effect in mid-2007. The drug per se States and the dates of the implementation of their drug per se laws follow:

Table 1. States With Drug Per Se Laws and Effective Dates

\begin{tabular}{lc}
\hline \multicolumn{1}{c}{ State } & Effective Date of Drug Per Se Law \\
\hline Arizona & Drug Per Se Law for All Drivers \\
Delaware & June 28, 1990 \\
Georgia & July 10, 2007 \\
Illinois & July 1, 2001 \\
Indiana & August 15, 1997 \\
lowa & July 1, 2001 \\
Michigan & July 1, 1998 \\
Minnesota & September 30, 2003 \\
Nevada ${ }^{1}$ & August 1, 2006 \\
Ohio & September 23, 2003 \\
Pennsylvania & August 17, 2006 \\
Rhode Island & February 1, 2004 \\
Utah & July 1, 2006 \\
Virginia & May 2, 1994 \\
Wisconsin & July 1, 2005 \\
\hline \multicolumn{2}{c}{ Illegal for Drivers Under Age 21 } \\
\hline North Carolina & December 19, 2003 \\
South Dakota & \\
\hline \multicolumn{2}{c}{ Illegal for Drug Addict or Habitual User to Drive } \\
\hline California & \\
Colorado & \\
Idaho & \\
Kansas & \\
West Virginia & \\
\hline
\end{tabular}

\section{Objectives}

The two main objectives of this study were:

- Determining the effects of drug per se laws in terms of DUID arrests and convictions.

- Determining the extent to which the laws are used, how the laws are being used, document any special concerns or problems, and describe how and if they have been resolved.

\footnotetext{
${ }^{1}$ Nevada law has specific cutoff levels for certain prohibited substances
} 


\section{Study Approach}

To determine whether drug per se laws have had any positive or negative impact on DUID arrests and convictions and to determine what factors such as urine screening tests, DEC programs, etc., may enhance the effectiveness of per se laws, we attempted to gather two broad categories of information. These include: (1) archival DUID arrest and conviction data, and (2) information through structured discussions and meetings with State and local officials, prosecutors, and law enforcement.

In an effort to develop an understanding of the effects of having a drug per se law and how having a DRE program might relate to those effects, we visited States with and without drug per se laws, and with and without DRE programs. This allowed us to obtain a balanced view of how DUID laws function.

Thus, we gathered more detailed information, including that obtained through structured discussions and meetings, from 6 States. These included 3 States with drug per se laws and strong DRE programs (Arizona, Iowa, and Wisconsin), a State with a drug per se law and no DRE program (Michigan), a comparison State with a DRE program but no per se law (Colorado), and a State with neither (West Virginia).

We attempted to obtain records of archival data such as DUID arrests and convictions from local and State law enforcement and court agencies, and data on the number of DREs and the volume of cases in which they were engaged. We attempted to obtain data from two years prior to the implementation of the drug per se law through the present, for each State. Because in virtually every State the DUID offense is unified under the basic impaired-driving statute, the information was not tracked completely separately in any of the data systems. Consequently, we had to rely primarily on anecdotal assessments of arrest and conviction patterns as developed from discussions with police and prosecutors.

For the second objective, we conducted structured discussions and meetings with law enforcement officers, prosecutors, judges, Department of Motor Vehicle (DMV) officials, and others to gain an understanding of how the drugged-driving arrest process worked, any problems the drug per se law may have created, and any solutions identified. We used structured discussion guides (Appendix A) to guide our conversations with prosecutors and law enforcement. When conversing with other officials such as judges and court administrators, we used the prosecutor discussion guides to help structure the discussion. Information collected during these discussions included law enforcement's understanding of what is needed to make an arrest under a drug per se law, how that may be different from previous procedures, officer training, perceptions of likelihood of conviction, and prosecutors' understanding of the laws and ability to prosecute such cases. With law enforcement and prosecutors, we introduced the discussion as being about drugged driving and not drug per se in particular, so we could develop an understanding of whether they appreciated and articulated the difference between drugged driving cases based on impairment versus per se. In all of our discussions, we avoided leading the discussion by stating what we thought, but rather we listened and gathered information from those we interviewed.

We also interacted with people such as toxicologists, judges, Governor's Highway Safety Program (GHSP) officials, DRE coordinators and the like. For State-level site visits, we coordinated appointments through an appropriate contact person at the GHSP office. We typically left some open time during our two- to three-day visits to allow for referrals to other 
informants our initial contacts suggested. The site visits also yielded leads that were followed up by phone or e-mail. One focus throughout this field data collection activity was to be alert to identify potential sources of data about drugged-driving arrests and dispositions. 


\section{Jurisdictions Studied}

Specifically, the 6 States identified that suited the needs of this study for in-depth site visits were the following:

Table 2. States Selected for In-Depth Study

\begin{tabular}{lcc}
\hline \multicolumn{1}{c}{ State } & Drug Per Se Law & DRE Program \\
\hline Arizona & Yes & Yes \\
Colorado & No & Yes \\
lowa & Yes & Yes \\
Michigan & Yes & No \\
Wisconsin & Yes & Yes \\
West Virginia & No & No \\
\hline
\end{tabular}

In the remaining drug per se States, we did not conduct site visits or structured discussions, but we did summarize those States' drug per se laws, effective dates, sanctions, and drug specifics and implementation. We also sought archival arrest and conviction data.

The following table summarizes our efforts that feed into this report:

Table 3. States Summarized in Report

\begin{tabular}{lcccc}
\hline \multicolumn{1}{c}{ State } & Site Visit & $\begin{array}{c}\text { Structured } \\
\text { Discussions }\end{array}$ & $\begin{array}{c}\text { Updated } \\
\text { Knowledge of Law }\end{array}$ & $\begin{array}{c}\text { Arrest or } \\
\text { Conviction Data }\end{array}$ \\
\hline Arizona & $\mathrm{X}$ & $\mathrm{X}$ & $\mathrm{X}$ & $\mathrm{X}$ \\
\hline Colorado & $\mathrm{X}$ & $\mathrm{X}$ & $\mathrm{X}$ & $\mathrm{X}$ \\
\hline Delaware & & & $\mathrm{X}$ & \\
\hline Georgia & & $\mathrm{X}$ & \\
\hline Illinois & $\mathrm{X}$ & $\mathrm{X}$ & $\mathrm{X}$ & $\mathrm{X}$ \\
\hline Indiana & $\mathrm{X}$ & $\mathrm{X}$ & $\mathrm{X}$ & \\
\hline lowa & & & $\mathrm{X}$ & $\mathrm{X}$ \\
\hline Michigan & & & $\mathrm{X}$ & \\
\hline Minnesota & & $\mathrm{X}$ & \\
\hline Nevada & & $\mathrm{X}$ & \\
\hline Ohio & & $\mathrm{X}$ & $\mathrm{X}$ \\
\hline Pennsylvania & & $\mathrm{X}$ & $\mathrm{X}$ & \\
\hline Rhode Island & $\mathrm{X}$ & $\mathrm{X}$ & \\
\hline Utah & $\mathrm{X}$ & & $\mathrm{X}$ & \\
\hline Virginia & & & & \\
\hline West Virginia & & & & \\
\hline Wisconsin & & & & \\
\hline
\end{tabular}




\section{How This Report Is Organized}

We first present information gathered from the 6 States where we conducted site visits. This includes a summary of the law and its effective date, followed by more detailed information about the law, the statutory sanctions, and specifics about the drugs covered by the statute. We then discuss how the law is implemented, as learned from our site visit activities, followed by a tabulation of the data we were able to obtain from that State. In instances where the list of drugs covered is very detailed and lengthy, the information is provided in Appendix B. The 6 States for which this level of information is presented are:

- Arizona,

- Colorado,

- Iowa,

- Michigan,

- West Virginia, and

- Wisconsin.

We then present information on the nature of the DUID per se laws and data available on the remainder of the States with drug per se laws, which are:

- Delaware,

- Georgia,

- Illinois,

- Indiana,

- Minnesota,

- Nevada,

- Ohio,

- Pennsylvania,

- Rhode Island,

- Utah, and

- Virginia.

We conclude with a discussion of what we learned about the implementation of drug per se laws during this study. This discussion is limited, to a certain degree, because many States do not currently track drugged driving offenses separately from alcohol-impaired driving offenses. 


\section{Descriptions of Selected Study States}

We examined the implementation of drug per se laws through site visits, interviews with key informants, and structured discussions and meetings with prosecutors and law enforcement officers in 6 States. The starting point for the detailed descriptions of the statutes and sanctions was the November 2002 report, "Driving Under the Influence of Drugs (DUID) Legislation in the United States" (Walsh, Danziger, Cangianelli, \& Koehler, 2002). We then supplemented the information by examining the current statutes in each State and through interviews with State officials. Summaries of the results of those more detailed efforts appear next on a State-by-State basis. Some of the information about States' processes (e.g., the flowcharts) repeats from State to State but this format allows for each State's description to stand alone. 


\section{Arizona}

\section{State With Drug Per Se Law and Active DRE Program}

Arizona was selected as a State for more in-depth study because it is a State with both a drug per se law and an active DRE program. Thus, it provides an opportunity to examine how the law functions where there is likely to be fairly aggressive DUID enforcement and DRE officers may be available to assist other officers in case evaluation and court testimony.

\section{Summary of Arizona's Drug Per Se Law}

Arizona has a zero tolerance per se drugged driving law enacted for any controlled substances (Arizona Revised Statutes, Section 28-1381).

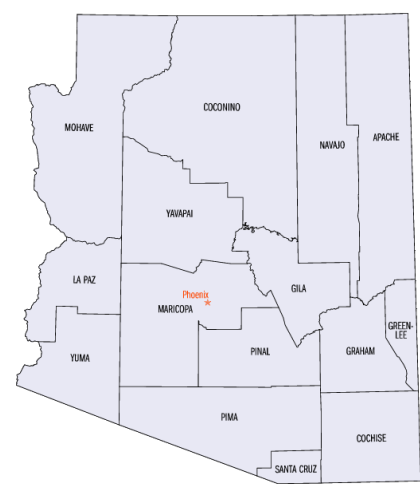

Figure 1. Arizona

Arizona law calls for a 24-hour mandatory imprisonment and not more than 6 months for a first offense. License suspension is 90 days to 1 year for a first offense.

\section{Effective Date}

Arizona's drug per se law took effect on June 28, 1990.

\section{Drug Per Se Law}

\section{A.R.S. § 28-1381.A1. Driving under the Influence}

A. It is unlawful for a person to drive or be in actual physical control of a vehicle in this State under any of the following circumstances:

1. While under the influence of intoxicating liquor, any drug, a vapor releasing substance containing a toxic substance or any combination of liquor, drugs or vapor releasing substances if the person is impaired to the slightest degree.

2. If the person has an alcohol concentration of .08 or more within two hours of driving or being in actual physical control of the vehicle and the alcohol concentration results from alcohol consumed either before or while driving or being in actual physical control of the vehicle.

3. While there is any drug defined in Section 13-3401 or its metabolite in the person's body.

B. It is not a defense to a charge of a violation of subsection A, paragraph 1 of this section that the person is or has been entitled to use the drug under the laws of this State.

C. A person who is convicted of a violation of this section is guilty of a class 1 misdemeanor.

D. A person using a drug prescribed by a medical practitioner licensed pursuant to title 32 , chapter 7,11, 13 or 17 is not guilty of violating subsection A, paragraph 3 of this section.

\section{Drug Specifics}

Any drug, any substance containing a toxic substance, or any drug (or its metabolite) defined in Section 13-3041. (See Appendix B for detailed list.) 


\section{Statutory Sanctions}

Table 4. Arizona Statutory Sanctions

\begin{tabular}{|c|c|c|c|c|c|}
\hline State & $\begin{array}{c}\text { Drug Per } \\
\text { Se Law }\end{array}$ & $\begin{array}{c}\text { DRE } \\
\text { Program }\end{array}$ & Effective Date & Law & Sanctions for First Offense \\
\hline$A Z$ & Yes & Yes & $\begin{array}{l}\text { June 28, } \\
1990\end{array}$ & $\begin{array}{l}\text { Arizona has a zero } \\
\text { tolerance per se } \\
\text { drugged driving law } \\
\text { enacted for any } \\
\text { controlled } \\
\text { substances (Arizona } \\
\text { Revised Statutes, } \\
\text { Section 28-1381). }\end{array}$ & $\begin{array}{l}\text { Criminal: Not more than } 6 \text { months } \\
\text { (mandatory } 24 \text { hours) imprisonment, } \\
\text { not more than } \$ 2,500 \text { (mandatory } \\
\$ 250 \text { ) fine for } 1^{\text {st }} \text { offense. } \\
\text { Court-Ordered Other: Court may } \\
\text { order community service, restitution, } \\
\text { completion of a driver-training course } \\
\text { probation, and/or penalty } \\
\text { assessment. } \\
\text { Administrative: Not less than } 90 \text { days } \\
\text { or more than } 1 \text {-year drivers license } \\
\text { suspension for } 1^{\text {st }} \text { offense. }\end{array}$ \\
\hline
\end{tabular}

Criminal: Not more than 6 months (mandatory 24 hours) imprisonment, not more than $\$ 2,500$ (mandatory \$250) fine for first offense; not more than 6 months (mandatory 30 days), not more than $\$ 2,500$ (mandatory $\$ 500$ ) for second offense within 60 months; $21 / 2$ to 3 years (mandatory 4 months).

Court-Ordered Other: Court may order community service, restitution, completion of a drivertraining course, probation, and/or penalty assessment. Defendants must also participate in a three-tiered process in which he/she is screened to establish whether he/she will be required to participate to court order.

Administrative: Not less than 90 days nor more than 1 year driver's license suspension for first offense (if not already suspended pursuant to implied consent law); 3 year revocation for third or subsequent offense within 60 months. Forfeiture of defendant-owned vehicle is mandatory under certain circumstances. 
Implementation and Handling of Arizona's DUID Cases

The law enforcement officer must have probable cause developed through observation of improper driving or equipment violation to make the initial stop of a driver. If, in contact with the driver, reasonable suspicion of alcohol or drug impairment is developed, further investigation is pursued.

If the driver shows physical impairment and has a low $\mathrm{BAC}$ as a result of a field sobriety test and a preliminary breath test, or if there are obvious signs of drug use (drug paraphernalia, etc.) apparent, the driver is placed under arrest, and the officer gathers further information.

A DRE may be called in to do an evaluation, or the arresting officer may gather additional information.

Typically, an officer requests a blood sample from the driver and sends the sample to the State or local agency lab for analysis; however, urine may also be requested.

In case of refusal, the law enforcement officer requests a warrant telephonically and, if granted, a blood sample is taken, usually at a hospital in metropolitan areas, but sometimes by an officer trained in phlebotomy.

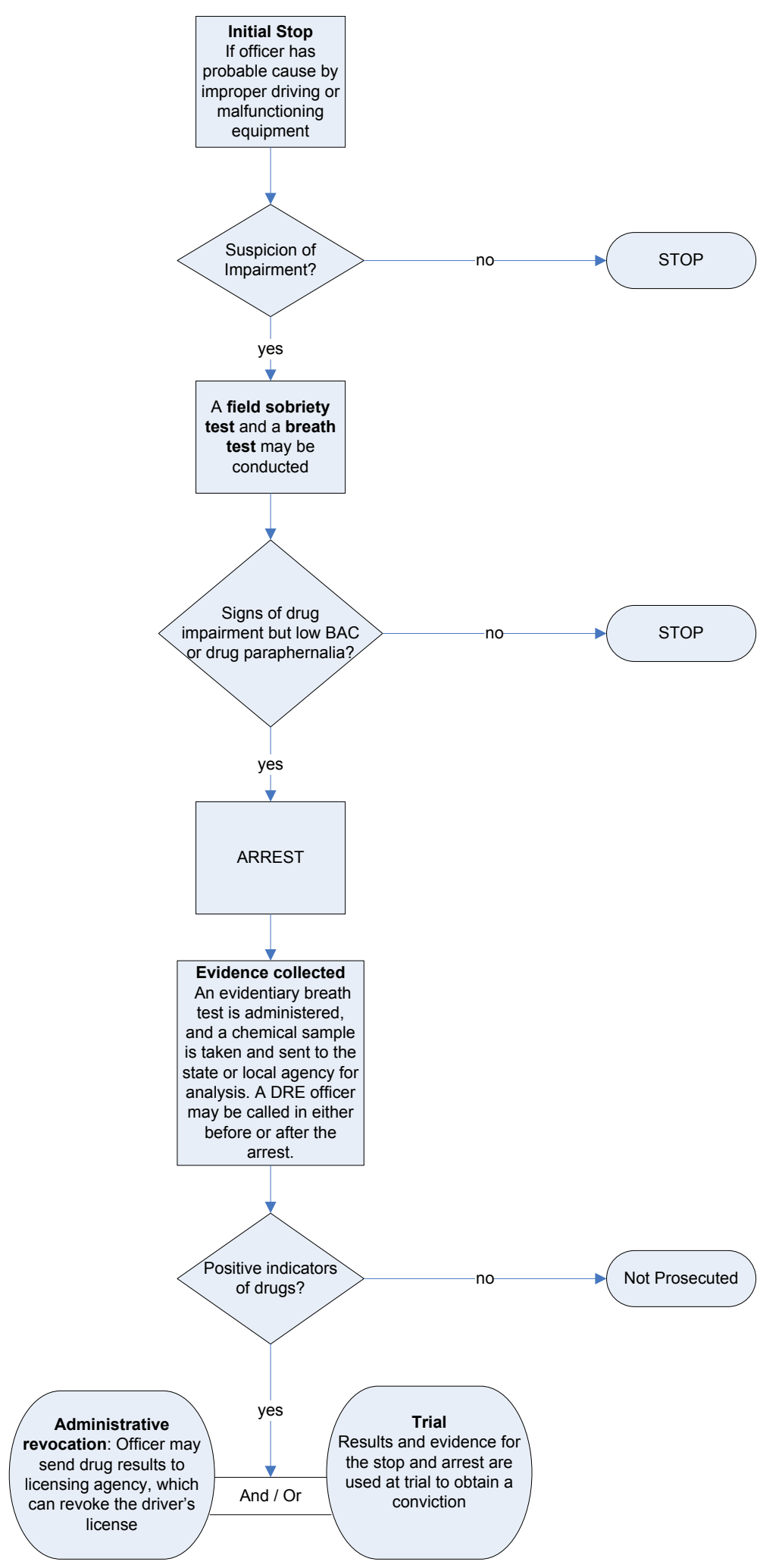

Figure 2. Arizona Flowchart 
If drug results are positive, the officer may send the results to the licensing agency, which can then administratively revoke the driver's license.

At trial, the presence of the drug, evidence for the stop, and suspicion of drug use are usually required to obtain a conviction.

Arizona's official driver history records and court disposition do not readily distinguish between the DUID and DUI-alcohol arrest and disposition. However, the Arizona Supreme Court's Administrative Office of the Courts was able to provide counts of charges by DUID and DUIalcohol.

\section{Discussions With State and Local Officials}

We met with the director of government affairs, Arizona Supreme Court, and had a general discussion about the adoption and implementation of Arizona's drug per se law. He was formerly special assistant to the Maricopa County Attorney specializing in impaired-driving issues and interaction with the legislature. He said Arizona's drug per se law is an administrative per se law in that the presence of drugs in a suspected offender's system is reported to the Motor Vehicle Division (MVD) and results in a license suspension. He said the per se provisions also apply to the criminal adjudication of the drugged-driving cases in the courts. Arizona routinely draws blood for impaired-driving offenders, whether alcohol or other drugs are suspected, and it is his impression the Department of Public Safety (DPS) operates one lab and four police agencies (in Mesa, Tucson, Scottsdale, and Chandler) operate their own labs. Arizona also has a very low test refusal rate in that most law enforcement agencies routinely request a warrant to compel the provision of a blood sample by those drivers who initially refuse to submit to tests.

We also met with both the Governor's highway safety representative and coordinator; they said an interest in DUID, and said they were in the process of automating their DRE training program in terms of monitoring maintenance of certification for DRE officers. They also said with Arizona's increased use of blood tests, the community colleges in Pima and Maricopa counties were offering phlebotomy courses police attended. They said the GHSP has also given some grants to the DPS laboratory to enhance the lab's drug analysis capabilities.

We met with the chief administrative law judge, Executive Hearing Office in the Division of Motor Vehicles, who verified the drug per se law is truly an administrative per se law. He said he was trying to moot the distinction between DUID and DUI-alcohol because there was no real distinction in terms of penalties or in how the cases were handled. Within his office, there is no internal distinction in counting the offenses or in statistical reporting. His experience was that most of the requested DUID hearings are in Phoenix or Tucson, which are the two largest jurisdictions in the State and the two counties with the largest local defense bar. Hearings are conducted in person, and are conducted in the county of arrest. Arizona has 14 counties, and the hearing office has 21 locations where hearings are conducted. It is his understanding of the process that, after the blood test results come back, if the result is positive, the officer generally serves an affidavit in person on the offender. If the offender chooses to request a hearing, it must be within 20 days from date of service for the request to be honored. It is his impression $80 \%$ of affidavits result in hearings because the defense approach is to use them to gather information during the hearing process that may inform their case in the criminal proceedings. In the previous year, they did approximately 15,000 impaired-driving hearings (both alcohol and drugs), which were conducted by the 13 administrative law judges in his office. They maintain separation and objectivity as administrative law judges, and hear cases for all matters concerning the Arizona 
Department of Transportation (DOT), including such issues as administrative license revocation (ALR), outdoor advertising issues, motor vehicle carrier issues, dealer licensing, and so forth.

We also met with a presiding city magistrate and a court administrator. It was their impression police currently receive more training about drug-impaired driving, and there are more druggeddriving cases. Urine is the primary medium for drug testing in cases they see in their court, and it takes from 90 days to 9 months for the DPS lab to provide results. They encourage police not to file a drugged-driving case until the drug test results are back, because the "clock" starts at that point (this approach is termed a "long-form complaint"). However, officers seem to resist the "long-form complaint" and file "short-form" complaints earlier. The "short-form complaints" include setting an initial court date, which, in effect, starts the clock running under the speedy trial law. The city magistrate says he seldom sees a drug per se case, and drugged-driving cases that come before him are argued based on impairment rather than per se. He sees a trend towards hearing increasing numbers of drugged-driving cases. He estimates that of the $5 \%$ of their cases that go to trial, $80 \%$ result in convictions.

\section{Summary of Law Enforcement Perspective}

We conducted three meetings with police officers in Arizona, to develop an understanding of law enforcement perspective of enforcing DUID laws. Two of the meetings were in Phoenix, and one was in Prescott Valley. One of the Phoenix meetings was with five officers from a regular evening patrol shift, not a specialized DWI enforcement unit. One officer, however, was a DRE instructor. The other Phoenix meeting was conducted with one of Phoenix' specialized DUI patrol squads. Six officers, all DREs, participated in that meeting. A third meeting was conducted in Prescott, Arizona, with officers from the Prescott Valley Police Department. Four officers participated in that group, two of whom were DREs.

The officers said a DUID stop generally starts with a routine traffic or impaired-driving stop (e.g., a traffic violation or an exhibit of erratic driving). Generally, the officer follows a standard screening of the individual, and if the driver seems impaired, requests the driver get out of the car. If there is no sign of alcohol, either through odor or other standard signs, or preliminary breath test (PBT) results, standard procedure is to call for a DRE to continue the investigation. The officers varied as to what alcohol level they might pursue just the alcohol offense, even if drugs are suspected. The DWI squad continues to pursue drugs with drivers with BACs up to .15 $\mathrm{g} / \mathrm{dL}$, whereas the other officers said if an individual's BAC was at .08 or higher, they would not pursue the drug investigation. Other than the specialized DUI patrol, the officers said waiting for a DRE was time-consuming, which often discouraged pursuing the DUID charge. This is true even in Phoenix, where records are kept of low-BAC test results, and officers are often queried as to why they did not call a DRE in those circumstances.

After the SFST in these jurisdictions, officers routinely use PBTs to administer a breath test. When a person suspected of DUID is taken to the station for an evidential breath test, an additional test (blood or urine) is requested to test for drugs. In Arizona, if an individual refuses at this point, the officer seeks a warrant to compel the individual to provide a blood sample.

The officers consistently observed that drug test results typically took quite a while. The officers reported most DUID cases did not go to trial, but were rather pled guilty once test results were available. However, they said that because of delays in obtaining chemical test results, they often did not submit paperwork to the MVD to obtain the administrative sanctions for DUID, because submitting that paperwork was dependent on having test results. Because of the delay, the 
officers chose to just pursue the criminal case and not bother with the administrative per se paperwork they associate with "night of arrest" processing for routine DUIs. The type of specimen requested is generally at the officer's discretion; however, if an individual who initially refused is compelled to submit, a blood sample is taken. Some of the department officers now conduct urinalyses. For this, the officer obtains a urine sample from the driver, and then conducts a preliminary test on a dip strip, which indicates positives for specific drug categories. They say this is quite useful, because the delays in getting laboratory results back often had resulted in cases being dismissed. With this preliminary evidence of a drug positive, they can tell the prosecutors they are likely to have an evidential test result that would be positive. Sometimes even a preliminary result and positive test will be sufficient to encourage the driver to enter a guilty plea before the laboratory analyses have been completed.

For crash-involved drivers, some officers reported they are able to obtain blood samples drawn by the emergency medical technicians (EMTs) who might draw blood while transporting the drivers to the emergency departments. Others said they had to wait to obtain a sample from the hospital; in general, however, it seemed they were able to obtain blood samples from crashinvolved drivers for whom they suspected drug or alcohol use. Interestingly, one of the officers said, since becoming a DRE, the laboratories seem to be more responsive in processing his samples quickly.

An officer said the administrative per se sanctioning system was really geared more towards alcohol offenses where the test results are generally immediately available. This observation was based on a perception the delay in getting drug test results holds up the implementation of the administrative sanction, and this delay makes it likely the criminal case would be resolved at about the same time the administrative sanction would have been applied. Additionally, his impression was the criminal conviction for the impaired-driving offense imposes a longer suspension than the administrative sanction and, thus, obviating the need for the administrative sanction.

The officers said gathering information for prescription drugs was sometimes more problematic because the laboratory requests that they specify the drug of interest. This often necessitated the driver admitting what drug may have been consumed. In that type of case, they felt it was best to obtain a blood sample rather than urine. The officers said the vast majority of the DUID cases plead guilty, particularly those with illegal drugs in their systems. They liked the fact that according to Arizona laws, a test only had to indicate metabolites rather than the active component of the drug in the test results.

The officers differed in their impression as to the frequency with which both drugs and alcohol are present in offenders. Some said it is low and others thought it is closer to half of the time. They were under the impression DUID arrest volume has been increasing over time. In general, the officers felt that because there are more DREs now than formerly, the delays are briefer in waiting for a DRE and officers are now more likely to call for a DRE than a few years ago. There was virtual unanimity among the officers that the command staff was supportive of DUI and DUID enforcement.

A problem that officers noted with the drug per se law component of the law was they could not take the license at the time of arrest and submit the administrative per se paperwork to remove the license from the offender for drug cases until they had the drug test results. 
In general, the officers were supportive of the drug per se law, particularly as it relates to criminal prosecution in that the mere presence of the drug or its metabolite is sufficient to obtain conviction.

\section{Summary of Prosecutorial Perspective}

We conducted structured discussions in separate meetings with six prosecutors in Arizona about how they prosecute DUID offenses. All of these prosecutors had experience with DUI cases, both at the felony and misdemeanor level.

The prosecutors said the majority of DUID cases do not go to trial but rather the suspects plead guilty. They said DUID cases were less likely to go to trial than DUI-alcohol cases. The one prosecutor who had been prosecuting prior to the adoption of the drug per se law in 1990 said the per se law has made prosecution of that offense much easier.

When asked about special issues related to DUID cases, the most prevalent negative issue mentioned was the need to wait for results of laboratory analyses of the blood or urine samples.

The prosecutors said few cases are contested, and those that are tend to be ones where the individual has been using a prescribed drug.

They reported no difficulties in developing probable cause, in that bad driving was sufficient to make the stop and if the officer sensed impairment, a blood or urine sample could be obtained. Some said because most drugs do not offer a smell like alcohol, the suspicion of drug use must be based on other signs.

When prosecuting a case, the prosecutors said several witnesses may be needed, including the arresting officer, the DRE (if used), and the criminalist or toxicologist who analyzed the biological sample. All of the prosecutors said a DRE was not required to make an effective prosecution; however, some did indicate having a DRE involved in the case could make it easier to prosecute.

The prosecutors said they typically pursue DUID even if there is a BAC at or above $.08 \mathrm{~g} / \mathrm{dL}$; however, they did said many officers probably do not pursue obtaining evidence supporting a DUID prosecution if the BAC is .08 or above.

The prosecutors we spoke to all said they did not plea bargain DUID cases as a means of obtaining a conviction for a drug possession or distribution offense. The point was made that sometimes separate prosecutors would be prosecuting the DUID case versus a felony possession case. Relative to straight DUI-alcohol cases, most of the prosecutors said, with the exception of prescription drug offenders, DUID offenders were more likely to plead guilty to the offense. When asked if the disposition of DUID cases had changed over time, all of the prosecutors, except the most experienced one (who felt the law had helped in obtaining convictions) who was prosecuting DUID prior to the per se law in 1990, felt the pattern of dispositions for DUID cases has remained consistent over the last several years. In terms of their perceptions of whether drugimpaired driving itself is changing over time, their general perception was the actual behavior was probably not changing much, but increased officer awareness and a greater number of DREs has lead to the offense being charged more often.

With the exception of prescription drugs, the prosecutors felt the per se aspects of the DUID statute makes it as easy, or easier, to prove than the $.08 \mathrm{~g} / \mathrm{dL}$ alcohol per se law. Prescription drug-based prosecutions were reported to be more difficult to pursue because the offender could 
argue the medical need for using the drug. Two of the six prosecutors felt DUID conviction rates have increased over time, one of whom attributed that to better quality detection and investigations. However, the others felt the conviction rates have remained relatively constant for the past several years.

The prosecutors said the per se law makes it so they have less of need to prove impairment, but one said they still tried to demonstrate impairment in case the jury dismissed the chemical test results. Only one prosecutor felt judges perceived the drug per se offense differently than the alcohol one, saying some judges think the test results may indicate drug use for some drugs up to a month prior to the offense.

Prosecutors who were familiar with the DEC program were very supportive of it. In general, the prosecutors felt the police officers were aware of the drug per se law, but some felt those with special training are more inclined to be looking for drug-impaired drivers. For the most part, prosecutors felt the public was supportive of the DUID laws and some felt the public thought that was an even more severe offense than alcohol-impaired driving.

\section{DUID Data}

Data for DRE evaluations for Arizona were obtained from the State DRE coordinator. The DRE coordinator reported there were 314 active DRE certified officers in the State as of 2004. The International Association of Chiefs of Police (IACP) reported there were 390 DREs in Arizona at the end of 2007.

DUI-alcohol charging data were obtained from the Arizona Supreme Court's Administrative Office of the Courts (AOC) and includes both alcohol and drug charges. The AOC estimates $3.5 \%$ of DUI charges are for DUID. DUID conviction data was not available. 
Table 5. Arizona's Summary Data on DUID and DUI Actions

\begin{tabular}{|c|c|c|c|c|c|}
\hline Year & $\begin{array}{c}\text { DRE } \\
\text { Evaluations } \\
\end{array}$ & $\begin{array}{c}\text { DUID } \\
\text { Charges }\end{array}$ & $\begin{array}{c}\text { DUID } \\
\text { Convictions* }\end{array}$ & $\begin{array}{l}\text { DUID Lesser } \\
\text { Offense } \\
\text { Convictions* }\end{array}$ & $\begin{array}{c}\text { DUl-Alcohol } \\
\text { Charges }^{* *}\end{array}$ \\
\hline 2005 & 3,224 & 3,099 & & & 85,448 \\
\hline 2004 & 3,034 & 3,088 & & & 85,140 \\
\hline 2003 & 2,872 & 3,001 & & & 82,725 \\
\hline 2002 & 2,147 & 2,858 & & & 78,802 \\
\hline 2001 & 1,700 & 2,417 & & & 66,645 \\
\hline 2000 & 1,619 & 2,378 & & & 65,577 \\
\hline 1999 & 1,593 & 2,328 & & & 64,196 \\
\hline 1998 & & 2,077 & & & 57,280 \\
\hline
\end{tabular}

${ }^{*}$ No available data

**This data is for the fiscal year, not the calendar year. The Arizona fiscal year is July 1 to June 30 .

*** Per Se law took effect

Arizona is one of the few States that provided data distinguishing between DUID and DUI alcohol cases. In this case, the data presented are based on information provided by the State Supreme Court's AOC. It represents their estimates of DUID charges filed. Unfortunately, they are estimates and data were available only going back to fiscal year 1998 and the drug per se law went into effect in 1990. Thus, we cannot review the data in terms of whether passage of the law influenced charging patterns. However, their estimates indicate DUID charges increased over the 8 -year period and by 2005 were nearly 1.5 times the frequency they were in 1998 . The number of DRE evaluations reported by the State DRE coordinator more than doubled over the 19992004 period. Clearly, these figures, particularly DUID charges filed, are not precise, but in the opinion of the AOC, DUID charging events have been increasing over time. 


\section{Michigan}

\section{State With Drug Per Se Law With DRE Activity}

Michigan was selected as a State for more in-depth study because it is a State with a drug per se law but without an active DRE program. This provided an opportunity examine how the law functions where the arresting officers are likely to have to make their DUID cases based on their routine training and without the likelihood of obtaining assistance from other officers such as DREs in offender evaluation and court testimony.

\section{Summary of Michigan's Drug Per Se Law}

Michigan has a zero tolerance per se drugged driving law for controlled substances. ${ }^{2}$ (Michigan Compiled Laws 257.625)

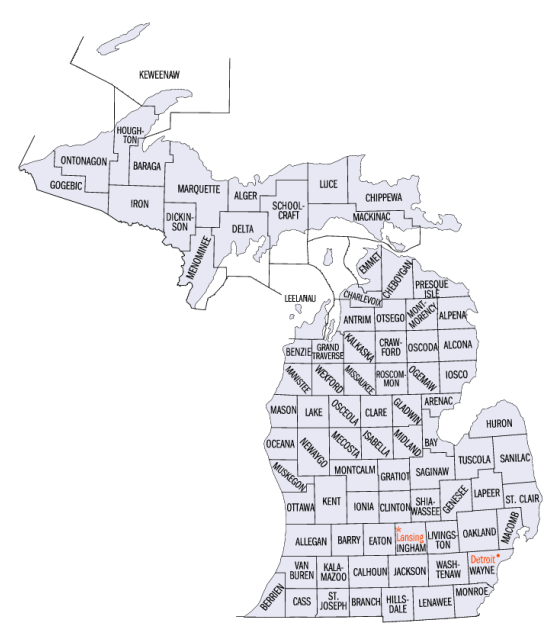

Figure 3. Michigan

Michigan's law calls for not more than 93 days (no mandatory) imprisonment and not more than $\$ 500$ fine for first offense, and not more than 180 days (no mandatory) suspension of license for first offense.

\section{Effective Date}

Michigan's drug per se law took effect on September 30, 2003.

\section{Drug Per Se Law}

\section{M.C.L. $§ 257.625$. Operating motor vehicle while intoxicated (OWI)}

(1) A person, whether licensed or not, shall not operate a vehicle upon a highway or other place open to the general public or generally accessible to motor vehicles, including an area designated for the parking of vehicles, within this State if the person is operating while intoxicated. As used in this section, "operating while intoxicated" means either of the following applies:

(a) The person is under the influence of alcoholic liquor, a controlled substance, or a combination of alcoholic liquor and a controlled substance.

(b) The person has an alcohol content of 0.08 grams or more per 100 milliliters of blood, per 210 liters of breath, or per 67 milliliters of urine, or, beginning October 1, 2013, the person has an alcohol content of 0.10 grams or more per 100 milliliters of blood, per 210 liters of breath, or per 67 milliliters of urine.

(2) The owner of a vehicle or a person in charge or in control of a vehicle shall not authorize or knowingly permit the vehicle to be operated upon a highway or other place open to the general public or generally accessible to motor vehicles, including an area designated for the parking of motor vehicles, within this State by a person if any of the following apply:

\footnotetext{
2 Although cannabis metabolites are excluded under the statutory language of the drugged driving law, MCL 257.625(8), Michigan's Supreme Court has ruled that cannabis metabolites are included as well. (Michigan v. Derror).
} 
(a) The person is under the influence of alcoholic liquor, a controlled substance, or a combination of alcoholic liquor and a controlled substance.

(b) The person has an alcohol content of 0.08 grams or more per 100 milliliters of blood, per 210 liters of breath, or per 67 milliliters of urine or, beginning October 1, 2013, the person has an alcohol content of 0.10 grams or more per 100 milliliters of blood, per 210 liters of breath, or per 67 milliliters of urine.

(c) The person's ability to operate the motor vehicle is visibly impaired due to the consumption of alcoholic liquor, a controlled substance, or a combination of alcoholic liquor and a controlled substance.

(3) A person, whether licensed or not, shall not operate a vehicle upon a highway or other place open to the general public or generally accessible to motor vehicles, including an area designated for the parking of vehicles, within this State when, due to the consumption of alcoholic liquor, a controlled substance, or a combination of alcoholic liquor and a controlled substance, the person's ability to operate the vehicle is visibly impaired. If a person is charged with violating subsection (1), a finding of guilty under this subsection may be rendered.

(8) A person, whether licensed or not, shall not operate a vehicle upon a highway or other place open to the general public or generally accessible to motor vehicles, including an area designated for the parking of vehicles, within this State if the person has in his or her body any amount of a controlled substance listed in schedule 1 under section 7212 of the public health code, 1978 PA 368, MCL 333.7212, or a rule promulgated under that section, or of a controlled substance described in section 7214(a)(iv) of the public health code, 1978 PA 368, MCL 333.7214.

\section{Drug Specifics}

Schedule I Controlled Substances (See Appendix B for detailed list). 


\section{Statutory Sanctions}

Table 6. Michigan Statutory Sanctions

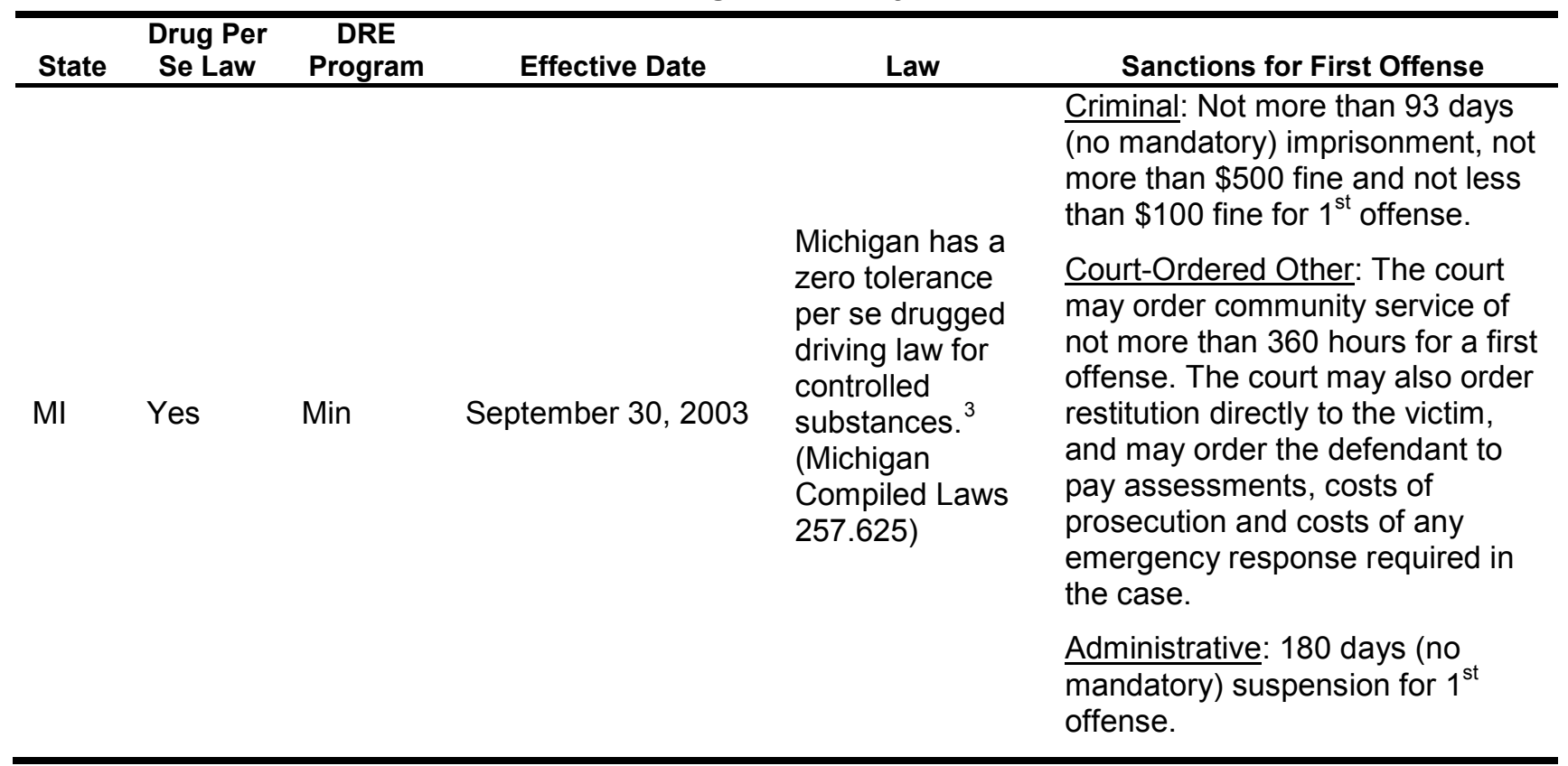

Criminal: Not more than 93 days (no mandatory) imprisonment, not more than $\$ 500$ fine and not less than $\$ 100$ fine for first offense; 5 days (mandatory) to 1 year, $\$ 200$ (mandatory) to $\$ 1,000$ for second offense within 7 years; 1 year (mandatory) to 5 years, $\$ 500$ (mandatory) to $\$ 5,000$ if violation occurs within 10 years of two or more prior convictions. These third offenses are felonies and probation will be ordered. Sanctions are the same for both the under-the-influence offense and the visibly impaired offense.

Court-Ordered Other: The court may order community service of not more than 360 hours for a first offense; not less than 30 days and not more than 90 days for a second offense in addition to or lieu of jail time with some minimum mandatory periods if done in lieu of imprisonment. The court may also order restitution directly to the victim, and may order the defendant to pay assessments, costs of prosecution and costs of any emergency response required in the case.

Administrative: 180 days (no mandatory) suspension for first offense; not less than 1 year (mandatory) revocation for second OWI offense or any serious impairment-related OWI; not less than 5 years (mandatory) for any subsequent offense within 7 years.

\footnotetext{
3 Although cannabis metabolites are excluded under the statutory language of the drugged driving law, MCL 257.625(8), Michigan's Supreme Court has ruled that cannabis metabolites are included as well. (Michigan v. Derror).
} 


\section{Implementation and Handling of Michigan's OWID Cases}

An officer must have probable cause developed by observing improper driving or an equipment violation in order to make the initial stop.

If the driver shows physical impairment and a low BAC from a field sobriety test and a preliminary breath test, or there are obvious signs of drug use (drug paraphernalia, etc.) apparent, the driver is placed under arrest and the officer gathers further information.

Michigan does not have an active DRE program (there is only one DRE officer in the State) so the assessment of the individual for drug impairment is made by the arresting officer. If the $\mathrm{BAC}$ is low and the offender seems impaired, a blood sample is requested after arrest.

In the case of refusal, a warrant is requested by an officer appearing before a magistrate and a blood sample is taken, usually at a hospital.

Typically, an officer requests a blood sample from the driver and sends the sample to the State lab for analysis. The State lab wants the officer to indicate the suspected drug if possible in order to limit the analysis costs.

If drug results are positive, the officer may send them to the licensing agency, which can then administratively revoke the driver's license.

Officers, prosecutors and judges interviewed said most

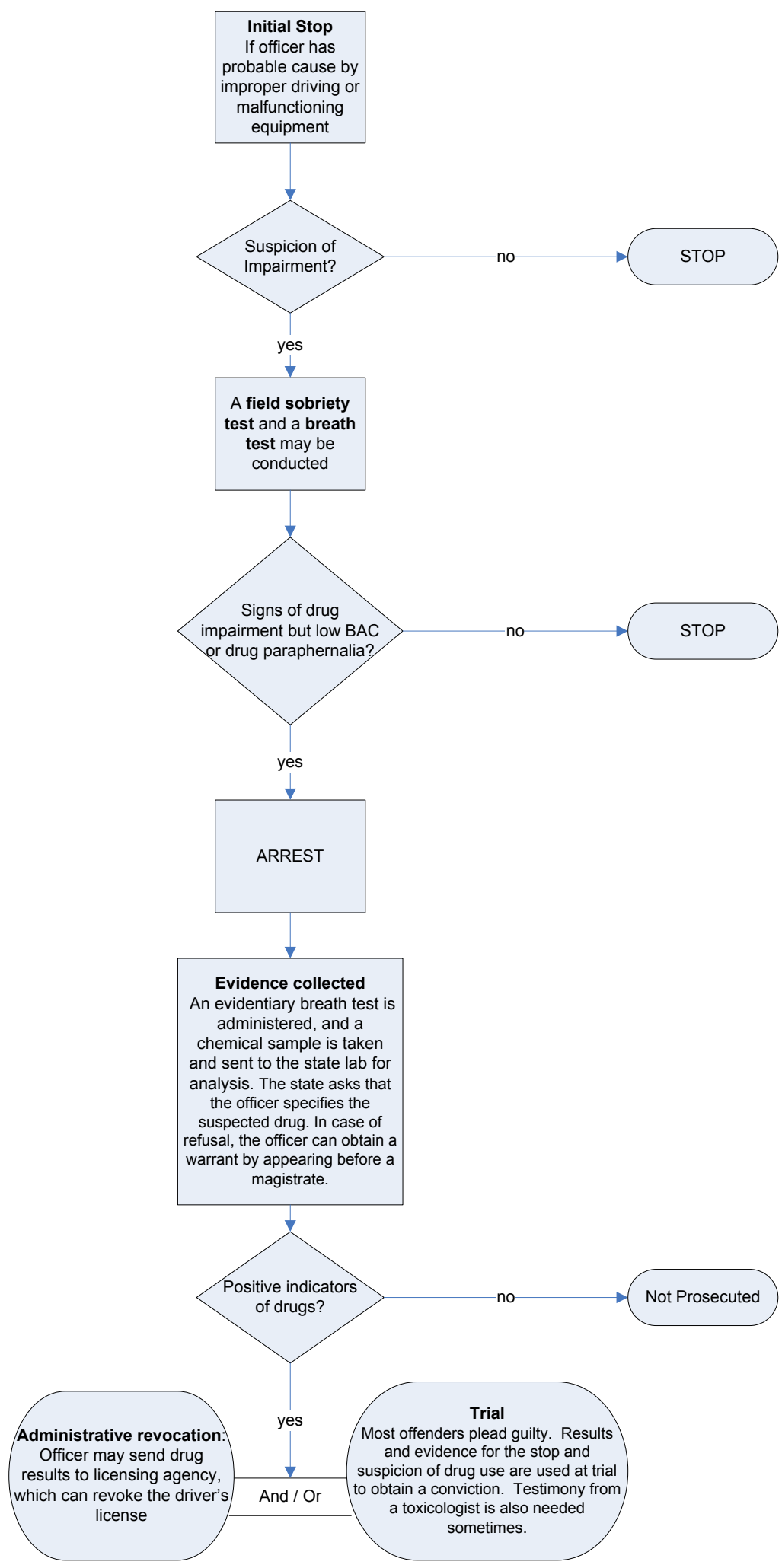

Figure 4. Michigan Flowchart 
Operating While Under the Influence of Drugs (OWID) cases plead guilty. At trial, the presence of the drug and evidence for the stop and impairment are usually required to obtain a conviction. Sometimes, testimony from a toxicologist is required.

Official records do not readily distinguish between the OWID and OWI-alcohol arrest and disposition, except for an offense associated with causing serious or fatal injury while having drugs in one's system.

\section{Discussions With State and Local Officials}

We met with the manager of the Planning and Program Operations Section, the Alcohol Program coordinator, and the Law Enforcement Liaison coordinator, all of the Office of Highway Safety Planning (OHSP) housed within the State Police. When asked about perceptions of awareness of the drug per se law, these State officials said the State Police do an excellent job of making officers aware of any impaired-driving law changes, and their office does periodic training, including sending law enforcement liaison personnel to individual agencies to train them on the new laws. There are 83 county sheriffs in Michigan.

They said most police officers are aware of the new drug per se law and large or mid-size departments were made aware of it and did training about the change in the law when the per se law went into effect.

Their impression was the general public probably has some general awareness they should not do drugs and drive. However, the public probably does not associate the same penalties for alcoholimpaired driving and drug-impaired driving. It was their opinion that outside of the general medical community, the public probably does not really know what controlled substances are.

They said a reluctance to invest in a DRE program maintaining a cadre of DRE-trained officers. They reported that in the early 1980s the founders of DRE came to Michigan and implemented a similar program having to do with the horizontal gaze nystagmus test, one of three parts of what is now the Standard Field Sobriety Test. However, the State Police found when they trained officers, the officers would then transfer to another shift, and the training time and costs went out the window. In their opinion, the cost was excessive and keeping up training certification was difficult. Thus, they abandoned the program.

They said, in Michigan, if there is a stop for OWI and if the officer suspects drugs other than alcohol, the officer can request a blood sample from the driver. If the suspect refuses, the officer requests a search warrant that takes about 20 minutes to obtain, and the officer then takes the offender to a medical facility to have blood drawn. With that process, if there are drugs involved, they are likely to be detected. They feel that is a good system.

They said with low BACs, police are requesting drug screens for a number of drugs and that, with the per se law, they perceive a significant rise in drug screening in the past two years. That has been a challenge for the State toxicologist because it places the burden of screening a larger number of samples than before the per se law was implemented.

They also felt prosecutors seem more comfortable with alcohol charges than OWID, perhaps because they are more accustomed to prosecuting the alcohol offense.

They also said it is reasonable to assume if a person is charged and convicted of a drugged driving charge, and if alcohol was present, the alcohol level would have been less than .08. That 
is, if an arrestee was at or above the alcohol per se level, the drug per se case would not be pursued.

They said the courts are currently undergoing a significant data warehouse project, and other departments of the State government are also undergoing a significant update. They estimated that in 2009 the data system would be significantly updated, at which time more detailed information on OWID cases might be available.

We also met with a manager and analyst from the Driver Assessment and License Appeal Division of the Michigan DMV to discuss the availability of OWID data at the Michigan Secretary of State's Office. They said data specifically addressing OWI-drugs was not available in their system, with the exception of cases where offenders are found guilty of a specific lesser included offense for drugged driving called Operating With Presence of Drugs (OWPD). In some instances, people are initially charged with that offense, and in others they are initially charged with Operating While Intoxicated or Operating While Impaired. Thus, summary data relating to that offense tend to show greater numbers of people convicted of the OWPD offense than are originally charged with it.

We also met with two district court judges, one of whom was an OWI/drug court judge. The OWI court judge started one of the first such courts in the Nation in 1997 in Michigan. OWI courts treat impaired drivers instead of just punishing them, and are typically for multiple or felony offenders. He believes jail time provides only a short period of public safety, but addiction intervention treatment actually treats underlying substance abuse and addiction issues.

He also said he has not seen a major impact as a result of the drug per se law (of the OWID law). He estimates he has probably had five or six contested impaired-driving trials in the last few years - much less than when he was first on the bench - because the offenders all plead guilty and go in a treatment program rather than incarceration for multiple offenders. He said the per se law has had little effect on the courts as there are not many trials because most offenders plead guilty and go into the program.

He said Michigan has major budget problems, and no drugged or drunk drivers go to prison until their third or fourth offense, because the State prisons are full and cannot take them, and county jails are not reimbursed for their expenses.

He was not aware of any jury trial on OWI-Drugs in the area.

The second judge formerly worked for the Michigan Senate, and has served as an assistant prosecuting attorney working in the district circuit and probate courts. She has been a district court judge since 2001. She presides over the specialized sobriety court.

When asked how the drug per se system is operating, she said public awareness has grown, even for the drug per se crime.

She said she had little experience with drugged driving cases. She has not had even one case of operating under the influence of drugs in her community. She was not sure if police either are not identifying them, or are labeling them as OWI-alcohol, although it seems easier or more common to arrest for an alcohol-related offense than a drug-related one. When asked if cases get onto her calendar that had been pled before trial, she said she has to sign off on any kind of plea bargain or dismissal if it is on her calendar. If a subject pleads impaired (lesser included offense) prior to reaching the calendar, she has to accept the plea. 
When asked if she would treat a drugged driving case differently than an alcohol case, she said she would treat them the same, with either a weekend treatment program with a victim impact panel or an alcohol/drug safety course.

We met with a management analyst at the Michigan State Court Administrative Office who said office did not have a way in their data system to identify OWID cases specifically.

We also met with the supervisor of the Michigan State Toxicology Unit. The State toxicology laboratory handles a mix of driving-related and homicide cases. She believes the State laboratory handles the vast majority of toxicology cases, because agencies do not have to pay to use them. Private labs, on the other hand, charge about $\$ 150$ dollars per analysis.

She said when a blood sample comes in, it is contained in a box the laboratory provides. The laboratory packages and distributes pre-packed lab boxes to appropriate agencies (e.g., police departments and hospitals throughout Michigan), containing everything a phlebotomist needs to draw blood, including a chain of custody (COC) form. Police departments and hospitals call the lab's warehouse for additional kits. Each boxed kit has blood tubes, stickers, and forms. All the phlebotomist at the hospital has to do is use the kit, seal the sample, and mail it. She said she has never experienced a problem with COC issues.

The laboratory does an immuno-assay screen on the blood samples and then confirms the positives; if there are multiple hits for various drugs, they conduct a GC/MS (gas chromatography-mass spectrometry) test on every positive. The laboratory does an alcohol test on every sample, but tests drugs only on request, totaling about $30 \%$ of all samples submitted. She estimated the laboratory did between 5,000 to 6,000 toxicology cases last year, and will do about the same this year; of these, about 3,000 contain marijuana.

Michigan's law added blood to the options for biological specimens in 2001. She said at that time, the toxicology caseload tripled and "went through the roof" with a huge volume and demand increase, partly due to blood analysis of marijuana. A driving force for that increase may have been that it was easy to send the samples for analysis to the State laboratory, and to check multiple boxes on the form, requesting tests for multiple drugs.

In 2003, Michigan's drug per se law took effect, and the illegal per se limit for alcohol was reduced from .10 BAC to .08 , but she said the lab's caseload did not change appreciably.

She said the laboratory prefers arresting officers specify what drugs they would like to have screened, but sometimes the arresting officers do not provide drug names. There is a box on the form the officer checks. The laboratory will screen for drugs if the BAC is less than .12. If the arresting officer requests a screen for marijuana and the analysis comes back negative for marijuana, then the laboratory sends back the results without searching for other drugs.

All samples get tested for alcohol. Most (80\% to 90\%) of the incoming samples are blood, but a few are urine samples. Officers may be motivated to request blood samples because it is easier to get blood than urine. She said agencies might prefer urine testing because it takes less time to get the results back. However, she also said she tries to educate the police agencies that prosecuting for OWID is best done with a blood sample.

In her opinion, the drug per se law did not have marked effect on the laboratory's volume.

She said she receives about 500 subpoenas for OWI cases per year and out of those 500 subpoenas, only about $10 \%$ of them require testifying. For the most senior toxicologists at the 
laboratory, the subpoena usually involves a technical issue; however, for other staff, it is more of a game, with the defense wanting to see if the toxicology staff will show up for the court date.

\section{Summary of Law Enforcement Perspective}

In an effort to develop an appreciation of the perceptions of law enforcement about enforcing the drug per se law in Michigan, we conducted meetings with officers in the Detroit metropolitan area and another meeting with officers in Auburn Hills, Michigan. Both meetings included local police officers and State patrol officers. Eight officers participated, including Michigan's DRE officer.

The officers reported a typical OWID arrest starts with development of probable cause for the stop through a traffic violation or erratic driving. If the driver exhibits signs of impairment, they administer the SFST battery. Generally, the officers said if the breath test result indicates a level less than .08, they pursue the OWID investigation; otherwise they rely on pursuing the alcohol component of the offense. Interestingly, even though the statute describes a unified offense of alcohol, drugs, or a combination thereof, some officers said filing charges as either alcohol or drugs separately. They may indicate this because of a reported wait time of from two to eight months before test results are obtained.

Evidently, the distinction between OWID and the OWI-alcohol, in terms of the charging, is created by a Michigan rule requiring that once charged, the cases must be prosecuted within a certain period of time. In the OWID cases, the test results are handled in a different manner than the regular OWI cases because of the long wait, even though the actual charge is the same under the statute. The officers reported the prosecutor encouraged them to file only complaint warnings (notice that charges would later be filed) for the OWID cases, and the prosecutors would file charges when the blood test results were available, and thus start the clock on a timely prosecution of the criminal case.

The officers said blood was the biological medium of choice for the drug-related charges, and if the offender refused, they could obtain a warrant to draw the blood. In one jurisdiction, it was said officers needed the assistance of both prosecutors and judges to obtain a warrant, while in another jurisdiction, a warrant required only the judge. Some officers thought it was costly to have blood drawn at hospitals and others said obtaining blood samples and their results from hospitals, where they typically draw the blood for medical purposes, was often difficult because of the hospital personnel's perception they would be liable if they share information with police. Other officers reported obtaining the blood samples from the hospitals was fairly routine. The officers reported cost was often an issue in terms of both the drawing of the blood and in the cost of having the chemical analyses conducted, and they said the lab would like them to indicate what drug to look for. Michigan is a non-DRE State with only one DRE officer in the entire State, according to the officers. However, they said they frequently asked the offender what drug they were taking, and the officer then reported the drug to the laboratory when sending in the analysis request.

In the Auburn Hills area, police said the district court attempts to recover costs associated with impaired-driving arrests and even charges the offender more for a refusal or for a blood test case, because it is more time consuming and because there are costs associated with the laboratory analyses. Though there was some discussion of court proceedings and the need to have people from the laboratory available to testify in contested cases, the officers generally said trials for OWID are relatively rare. One officer said his county prosecutor required the officer to jump 
through a lot of hoops before the prosecutor would go to court. There was some indication that in Detroit, a very large jurisdiction, many cases are dismissed because of prosecutor caseload. Officers said when they did testify, testimony was very similar for drugs as for alcohol, in terms of establishing probable cause and in demonstrating impairment through SFSTs to justify the blood or urine test.

The officers generally said there was no noticeable change for them brought on by the adoption of the drug per se law in 2003. However, there was a change in the OWI alcohol component of the law from .10 to .08 at the same time and they said it made their jobs more difficult because of increased cases and greater willingness of prosecutors to dismiss lower BAC cases, and that lower BAC cases were more likely to be contested.

\section{Summary of Prosecutorial Perspective}

We held individual structured discussions with six Michigan prosecutors about their handling of OWID cases and perceptions thereof. These prosecutors said drugged driving cases accounted for about $10 \%$ of the OWI cases they prosecuted. When asked about special issues related to those cases, one prosecutor said secondhand smoke was sometimes raised in jury trials as an argument. In other words, defendants would claim they had not directly consumed marijuana, but rather had been close proximity to someone who had. Another said OWID cases arise from crashes might present special issues, in terms of dealing with hospital test procedures. This problem does not present with police-collected blood. Prosecutors offered mixed opinions as to whether OWID cases were more or less likely to be contested. The Michigan prosecutors had mixed opinions on whether it was more or less difficult to develop probable cause for OWID cases, some indicating it was more difficult because there was no odor, except for marijuana. Prosecutors generally said there was a need for a laboratory expert as well as the arresting officer as witnesses. For contested cases, they said timeliness of obtaining laboratory test results is generally a problem in terms of delaying prosecution of the case, but not necessarily in obtaining convictions.

They universally said they did not need a DRE to testify at the case. They also said there was a recent Michigan Supreme Court decision said metabolites of marijuana were sufficient to obtain conviction for OWID.

Prosecutors generally said even if there was a BAC above .08, they pursued the OWID component of the case as well. Only one prosecutor said he would plea bargain the OWID case for possession or distribution pleading, and then only if it was a higher level of offense. The general reaction of the prosecutors was that the OWID cases and OWI-alcohol cases were pled guilty at about the same rate. They said there is no enhanced sanction for the OWID offense relative to the OWI-alcohol offense.

When asked if there had been changes over time in the patterns of dispositions of OWID, the reaction was mixed amongst the prosecutors. One said in some counties, OWID was now taken more seriously in terms of pleading down than in the past. Another said he felt the judges were getting tougher. However, a third prosecutor said offenders were now being allowed to go through the drug court process in lieu of serving jail time. Two of the prosecutors said they felt since the per se law was passed, more OWID cases are being brought. Some thought the per se law made it easier to obtain convictions, but others thought it did not change prosecution procedures and conviction patterns appreciably. Ironically, they almost universally felt the conviction rates have changed as a result of the per se law, and they generally said very few 
OWID cases resulted in jury trials, which is quite similar to their perception of OWI-alcohol cases. Most of the prosecutors felt it was now easier to prosecute OWID cases, and they universally said they no longer needed to prove impairment.

In general, the prosecutors did not feel there were recent increases in the volume of OWID cases, though they said they thought officers were more sensitive to the drugged driving issue because of the per se law.

\section{Data}

Data for OWPD arrests, OWPD convictions, OWI-alcohol arrests, OWI-alcohol convictions, impaired-driving arrests, and impaired-driving convictions for Michigan were provided by the Michigan Drunk Driving Audit. As said earlier, there is only one DRE certified officer in the State, which was confirmed by the IACP as of the end of 2007.

Table 7. Michigan's Summary Data on OWPD and OWI Actions

\begin{tabular}{|c|c|c|c|c|c|}
\hline Year & $\begin{array}{c}\text { DRE } \\
\text { Evaluations* }\end{array}$ & $\begin{array}{l}\text { OWPD } \\
\text { Arrests }^{* *}\end{array}$ & $\begin{array}{c}\text { OWPD } \\
\text { Convictions** }\end{array}$ & $\begin{array}{c}\text { OWI } \\
\text { Arrests }^{* * *}\end{array}$ & $\begin{array}{c}\text { OWI } \\
\text { Convictions }^{* * *}\end{array}$ \\
\hline 2006 & & 226 & 572 & 51,601 & 21,381 \\
\hline 2005 & & 215 & 676 & 52,235 & 22,631 \\
\hline 2004 & & 63 & 537 & 53,292 & 23,869 \\
\hline $2003^{* * * *}$ & & 1 & 26 & 53,354 & 25,127 \\
\hline 2002 & & & & 55,227 & 29,330 \\
\hline 2001 & & & & 54,857 & 26,591 \\
\hline
\end{tabular}

In Michigan, the State data systems do not distinguish between OWID and OWI alcohol except for the special category of cases involve operating a motor vehicle in the presence of drugs, which may be charged as such or may be the conviction offense for some individuals originally charged with the Operating While Intoxicated offense. Presumably, fewer people are initially arrested for this offense than eventually convicted because charges are amended after the outcome of the chemical test (presence of drugs) is known. However, many offenders who are arrested based on suspicion of impairment due to drugs are both charged and convicted under the more general category that may include either alcohol or other drugs and for which the data system provides no distinction between the two. However, there is a clear pattern of increases in charges and convictions for the OWPD offense over time though they still represent only a small fraction of the overall impaired-driving arrests and convictions overall. This is in the face of a slight decline in the volume of OWI arrests in general. 


\section{Colorado}

\section{State Without Drug Per Se Law but With Active DRE Program}

Colorado was identified as the State to be visited in conjunction with developing and understanding of the operations of States that have no drug per se law, yet have an active drug evaluation and classification (DEC) program. This could provide insight into the perceptions of those in a State that had a clear institutional interest in addressing DUID as evidenced by the DEC program, but had not yet adopted a drug per se law.

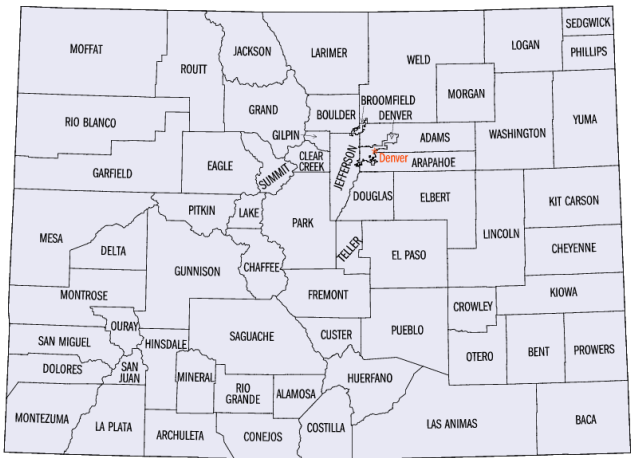

Figure 5. Colorado

\section{Summary of Colorado's Drug Law}

It is a misdemeanor for a person to drive who is impaired by one or more drugs, or if one is a habitual user of any controlled substance. Penalties are: DUI ${ }^{4}$ first offense - five days to 12 months imprisonment, $\$ 300$ to $\$ 1,000$ fine, license suspension for one year; $\mathrm{DWAI}^{5}-2$ days to 180 days imprisonment, $\$ 300$ to $\$ 1,000$ fine for first offense.

\section{Law}

\section{Colorado Revised Statutes§ 42-4-1301}

(1)(a) It is a misdemeanor for any person who is under the influence of alcohol or one or more drugs, or a combination of both alcohol and one or more drugs, to drive any vehicle in this State. (b) It is a misdemeanor for any person who is impaired by alcohol or by one or more drugs, or by a combination of alcohol and one or more drugs, to drive any vehicle in this State.

(c) It is a misdemeanor for any person who is an habitual user of any controlled substance defined in section 12-22-303(7), C.R.S., to drive any vehicle in this State.

(d) For the purposes of this subsection (1), one or more drugs shall mean all substances defined as a drug in section 12-22-303(13), C.R.S., and all controlled substances defined in section 1222-303(7), C.R.S., and glue-sniffing, aerosol inhalation, and the inhalation of any other toxic vapor or vapors.

(e) The fact that any person charged with a violation of this subsection (1) is or has been entitled to use one or more drugs under the laws of this State, including, but not limited to, the medical use of marijuana pursuant to section 18-18-406.3, C.R.S., shall not constitute a defense against any charge of violating this subsection (1).

(f) "Driving under the influence" means driving a vehicle when a person has consumed alcohol or one or more drugs, or a combination of alcohol and one or more drugs, which alcohol alone, or one or more drugs alone, or alcohol combined with one or more drugs affects the person to a degree that the person is substantially incapable, either mentally or physically, or both mentally and physically, to exercise clear judgment, sufficient physical control, or due care in the safe operation of a vehicle.

(g) "Driving while ability impaired" means driving a vehicle when a person has consumed

\footnotetext{
${ }^{4}$ DUI $=$ Driving under the influence of alcohol, drugs, or a combination of the two.

${ }^{5}$ DWAI $=$ Driving while ability impaired.
} 
alcohol or one or more drugs, or a combination of both alcohol and one or more drugs, which alcohol alone, or one or more drugs alone, or alcohol combined with one or more drugs, affects the person to the slightest degree so that the person is less able than the person ordinarily would have been, either mentally or physically, or both mentally and physically, to exercise clear judgment, sufficient physical control, or due care in the safe operation of a vehicle.

(h) Pursuant to section 16-2-106, C.R.S., in charging the offense of DUI, it shall be sufficient to describe the offense charged as "drove a vehicle under the influence of alcohol or drugs or both."

(i) Pursuant to section 16-2-106, C.R.S., in charging the offense of DWAI, it shall be sufficient to describe the offense charged as "drove a vehicle while impaired by alcohol or drugs or both." (5) Notwithstanding the provisions of section 18-1-408, C.R.S., during a trial of any person accused of both DUI and DUI per se, the court shall not require the prosecution to elect between the two violations. The court or a jury may consider and convict the person of either DUI or DWAI, or DUI per se, or both DUI and DUI per se, or both DWAI and DUI per se. If the person is convicted of more than one violation, the sentences imposed shall run concurrently. (6)(a) In any prosecution for DUI or DWAI, the defendant's BAC at the time of the commission of the alleged offense or within a reasonable time thereafter gives rise to the following presumptions or inferences:

(I) If at such time the defendant's BAC was 0.05 or less, it shall be presumed that the defendant was not under the influence of alcohol and that the defendant's ability to operate a vehicle was not impaired by the consumption of alcohol.

(II) If at such time the defendant's BAC was in excess of 0.05 but less than 0.08 , such fact gives rise to the permissible inference that the defendant's ability to operate a vehicle was impaired by the consumption of alcohol, and such fact may also be considered with other competent evidence in determining whether or not the defendant was under the influence of alcohol.

(III) If at such time the defendant's BAC was 0.08 or more, such fact gives rise to the permissible inference that the defendant was under the influence of alcohol.

(b) The limitations of this subsection (6) shall not be construed as limiting the introduction, reception, or consideration of any other competent evidence bearing upon the question of whether or not the defendant was under the influence of alcohol or whether or not the defendant's ability to operate a vehicle was impaired by the consumption of alcohol.

(c) In all actions, suits, and judicial proceedings in any court of this State concerning alcohol related or drug-related traffic offenses, the court shall take judicial notice of methods of testing a person's alcohol or drug level and of the design and operation of devices, as certified by the department of public health and environment, for testing a person's blood, breath, saliva, or urine to determine such person's alcohol or drug level. The department of public health and environment may, by rule, determine that, because of the reliability of the results from certain devices, the collection or preservation of a second sample of a person's blood, saliva, or urine or the collection and preservation of a delayed breath alcohol specimen is not required. This paragraph (c) shall not prevent the necessity of establishing during a trial that the testing devices used were working properly and that such testing devices were properly operated. Nothing in this paragraph (c) shall preclude a defendant from offering evidence concerning the accuracy of testing devices.

(d) If a person refuses to take or to complete, or to cooperate with the completing of, any test or tests as provided in section 42-4-1301.1 and such person subsequently stands trial for DUI or 
DWAI, the refusal to take or to complete, or to cooperate with the completing of, any test or tests shall be admissible into evidence at the trial, and a person may not claim the privilege against self-incrimination with regard to admission of refusal to take or to complete, or to cooperate with the completing of, any test or tests.

\section{Drug Specifics}

All substances defined as a drug, all controlled substances (See details in Appendix B) and glue sniffing, aerosol inhalation, and the inhalation of any other toxic vapor or vapors.

\section{Statutory Sanctions}

Table 8. Colorado Statutory Sanctions

\begin{tabular}{|c|c|c|c|c|c|}
\hline State & $\begin{array}{l}\text { Drug Per } \\
\text { Se Law }\end{array}$ & $\begin{array}{c}\text { DRE } \\
\text { Program }\end{array}$ & Effective Date & Law & Sanctions for First Offense \\
\hline \multirow{3}{*}{$\mathrm{CO}$} & \multirow{3}{*}{ No } & \multirow{3}{*}{ Yes } & & \multirow{3}{*}{$\begin{array}{l}\text { It is a misdemeanor } \\
\text { for a person to } \\
\text { drive who is } \\
\text { impaired by one or } \\
\text { more drugs, or if } \\
\text { one is a habitual } \\
\text { user of any } \\
\text { controlled } \\
\text { substance. }\end{array}$} & $\begin{array}{l}\text { Criminal: DUI: minimum } 5 \text { days to } 12 \\
\text { months imprisonment, } \$ 300 \text { to } \$ 1000 \\
\text { fine for } 1^{\text {st }} \text { offense; DWAI: minimum } 2 \\
\text { days up to } 180 \text { days, } \$ 100 \text { to } \$ 500 \\
\text { fine for first offense. }\end{array}$ \\
\hline & & & & & $\begin{array}{l}\text { Court-Ordered Other: The court must } \\
\text { order public service as follows for } \\
\text { DUI: not less than } 48 \text { to } 96 \text { hours ( } 48 \\
\text { mandatory) of useful public service } \\
\text { for } 1^{\text {st }} \text { offense. Additional fees will be } \\
\text { imposed for victim's compensation } \\
\text { fund and programs to address } \\
\text { persistent drunk drivers, among other } \\
\text { fees. For DWAl: } 24 \text { to } 48 \text { hours of } \\
\text { useful public service for first offense. }\end{array}$ \\
\hline & & & & & $\begin{array}{l}\text { Administrative: DUI: license } \\
\text { suspension for one year for first } \\
\text { offense; DWAl: points assessed for } \\
\text { first offense. }\end{array}$ \\
\hline
\end{tabular}

Criminal: DUI: Minimum 5 days to 12 months imprisonment, $\$ 300$ to $\$ 1,000$ fine for first offense; 90 days to 12 months, 500 to $\$ 1,500$ for second offense within 5 years; DWAI: minimum 2 days up to 180 days, $\$ 100$ to $\$ 500$ fine for first offense; 45 days to 1 year maximum imprisonment, $\$ 300$ to 1,000 fine for second offense in 5 years.

Court-Ordered Other: The court must order public service as follows for DUI: not less than 48 to 96 hours (48 mandatory) of useful public service for first offense; 60 to 120 hours for second offense in 5 years. Additional fees will be imposed for victim's compensation fund and programs to address persistent drunk drivers, among other fees. For DWAI: 24 to 48 hours of useful public service for first offense; 48 to 96 hours of useful public service for second offense in 5 years.

Administrative: DUI: license suspension for one year for first offense, license revocation for 1 year for second offense in 5 years; DWAI points assessed for first offense, for second offense in 5 years, license revoked for 1 year. 


\section{Implementation and Handling of Colorado's DUID Cases}

An officer must have probable cause developed by observing improper driving or equipment violation in order to make the initial stop. If, in contact with the driver, the officer develops reasonable suspicion of alcohol or drug impairment, further investigation is pursued.

Preliminary breath testers are sometimes used to determine $\mathrm{BAC}$ in the field. If a high BAC is present, the DUID charge is generally not pursued.

If the driver shows physical impairment and a low BAC, or there are obvious signs of drug use (drug paraphernalia, etc.) apparent, the driver is placed under arrest and further information is gathered.

A DRE may be called in to do an evaluation or the arresting officer may gather additional information.

Typically, the officer requests blood or urine tests from the driver and sends the sample to the State or local agency lab for analysis.

Results are usually available in five days to a month.

If drug results are positive, the officer may send them to the licensing agency, which can then administratively revoke the driver's license.

Police and prosecutors report

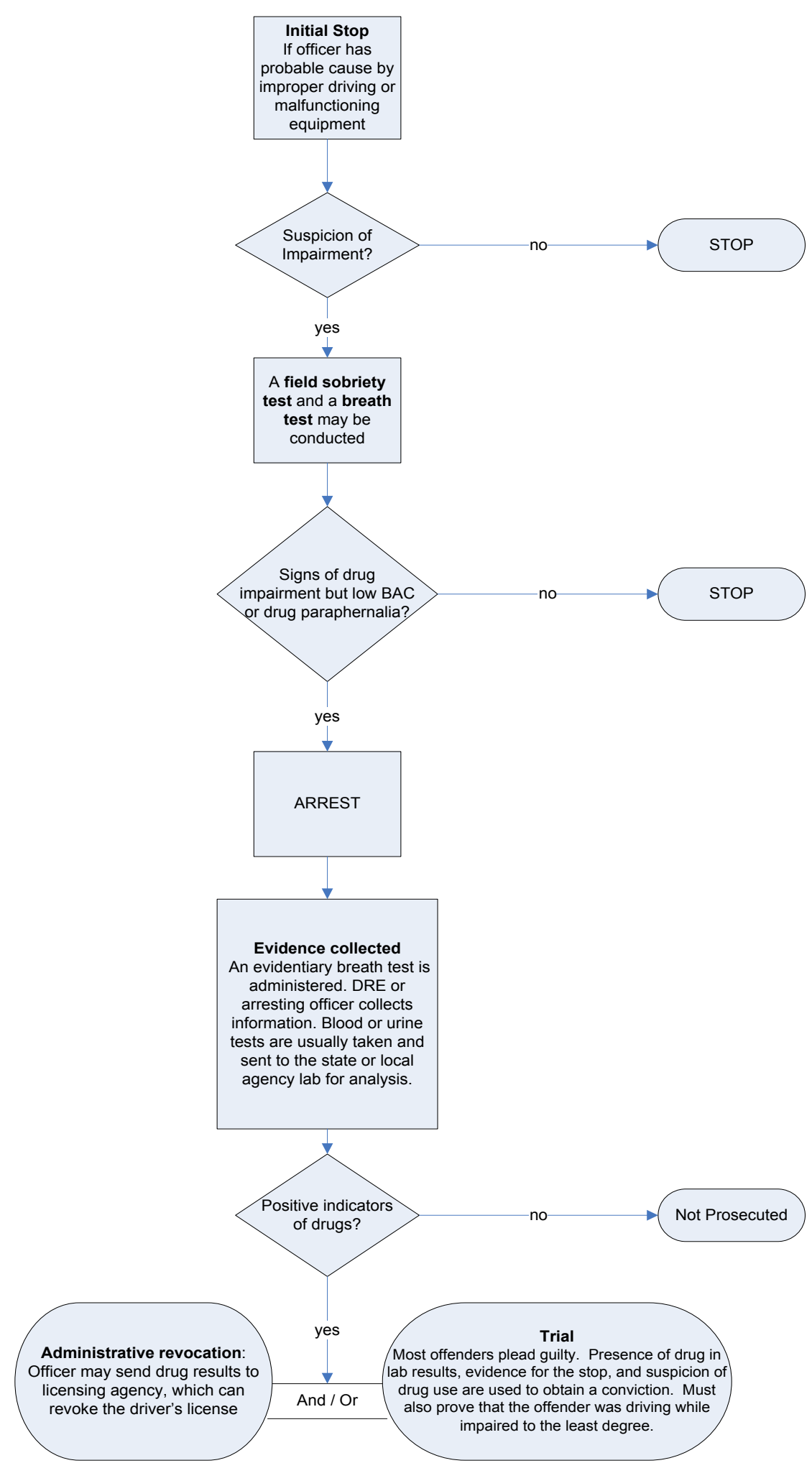

Figure 6. Colorado Flowchart 
most cases result in a guilty plea.

At trial, the presence of the drug in the offender and evidence for the stop and suspicion of drug use are usually required to obtain a conviction. In addition, it must be proven the offender was driving (while impaired to the least degree).

Colorado's official records do not readily distinguish between the DUID and DUI-alcohol arrest and disposition.

\section{Discussions With State and Local Officials}

We met with the State DRE and impaired-driving coordinator of the Colorado Department of Transportation, who is housed in the Governor's Highway Safety Program. He was our principal point of contact in identifying interviewees and arranging to meet with them. He said Colorado has an active and effective DRE program with 85 certified officers. The IACP reported there were 125 DREs in the State at the end of 2007.

We met with the manager of administration and the operations director of the Colorado DMV to ascertain how the DMV records and handles DUID offenses. They said that within Colorado's DMV record system DUID offenses are recorded under the same statute code as DUI-alcohol, and thus are not treated differently from a DUI-alcohol offense. Therefore a DUID offender listed under the DUI umbrella statute code would be eligible for the same sanctions as a DUIalcohol offender, including having an alcohol ignition interlock device installed in his or her vehicle. The interlock provision is interesting in that the device prevents operating a vehicle above a certain level of alcohol, but does not measure drugs other than alcohol. Thus it is conceivable offenders whose offense did not involve alcohol at all might still receive an alcohol interlock device. It is unlikely the Colorado DMV system would be very useful in identifying trends in DUID offenses over time.

We also met with a management analyst and a data analyst from the Division of Probation Services to discuss if and how DUID cases are recorded within the probation and court system. They said, statewide, cases are handled in 23 judicial districts, to which Probation Services provides support. According to their records, Colorado has approximately 30,000 DUI offenders on probation at any given time. Its office deals with monitoring cases that come through the State Court Administrator's Office. Offenders receive a drug and alcohol evaluation using the Adult Substance Use and Driving Survey (ASUDS) and subsequently receive treatment when appropriate. They said the statute for DUI-alcohol and DUID is not separate; rather impairment, whether by alcohol, drugs, or both, are treated as one. Treatment provided by Probation Services, however, is tailored for the specific offense: DUI-alcohol treatment is BAC-driven, whereas DUID requires the use of probation officers with special training. However, their data system does not distinguish between DUI-alcohol and DUID offenders. A potential issue brought up was the possibility that deferred cases may never make it to the DMV for their records and for the imposition of licensing sanctions.

In addition to sentencing differences depending on number of prior offenses, they said a large number of cases are pled down, most typically to a DWAI (Driving While Ability Impaired) or a Baby DUI, ${ }^{6}$ which has fewer points (8 rather than 12), allowing some offenders to get their

\footnotetext{
6 "Baby DUI" is a term commonly used for underage drivers with a limited BAC. It means driving a vehicle when blood or breath alcohol concentration is at least .02 but not more than $.05 \mathrm{~g} / \mathrm{dL}$ or 210 liters of breath; tested within 2
} 
license back more quickly. They explained, however, that all DUI cases go to the State court, and offenders and defense prosecutors are not allowed to plea down to a non-alcohol offense. They said the courts benefit tremendously from pled down cases, as this allows cases to move quickly through the system. Colorado has about a 2 to $4 \%$ trial rate on roughly 30,000 cases per year. Denver County Court, which handles about 2,000 cases, is outside the State system.

We also met with the chief hearing officer and the deputy chief hearing officer of the Colorado DMV to discuss any potential data sources for DUID cases. They confirmed what had been indicated by others - that Colorado's DMV records were unlikely to be able provide separate information on DUID cases. The Hearing Office department of the DMV deals specifically with DUI cases that have additional hearings. For example, at the expressed consent (their term for implied consent refusals) hearings, there is no record available to distinguish between alcohol and drugs. They are only made aware of whether it is a DUI-alcohol or DUID case based on the original officer write-up; however, that has no effect on the DMV case. They explained that based on the DMV history, there is no way to know what kind of case they are dealing with, because both DUI-alcohol and DUID fall under the same statute.

\section{Summary of Law Enforcement Perspective}

In order to develop an understanding of Colorado law enforcement officers' perspective on DUID enforcement, we conducted three meetings in different jurisdictions, with a total of 19 participants, and one structured discussion with two law enforcement officers together.

According to officers, the typical DUID case begins with a stop based on some form of probable cause such as a traffic infraction or evidence of driving associated with impaired driving such as wide turns or swerving. Once a stop is made, the officer then determines whether the driver is impaired. The consensus among the officers was that a normal DUI-alcohol investigation proceeds from that point. In other words, if alcohol or drug impairment is suspected, the officer gets the driver out of the vehicle and performs the SFST. There was variation amongst the officers in terms of whether they used a preliminary breath test in the field, some indicating they used it, and others not, but generally indicating it was at the discretion of the officer. Typically, a drug investigation does not ensue unless impairment is evident and there is no indication of alcohol. At that juncture, officers may call for a DRE, but that is dependent on the availability of DREs in the jurisdiction as well as the level of comfort the individual officer may have in pursuing a DUID case on his or her own. Some officers may suspect drugs but not be comfortable with pursuing the DUID investigation. This is understandable, in that, for example, one officer said that in the Denver area, there are only four DRE officers, and thus, even though they are on call, some DUID offenders are not charged with that offense by officers who feel the wait time is too long for a DRE and who are not comfortable with the DUID process. However, another jurisdiction, Colorado Springs, has regular patrol officers trained to process DUID cases, and there are specialized officers who may take those cases over from street officers.

If impairment is suspected, the officer asks for a blood or urine sample, or both, and a driver's failure to provide a sample constitutes a refusal. Again, as in many other jurisdictions, the officers said if there is a high BAC on the breath tests, typically the alcohol violation is pursued and the drug-impaired driving violation is not pursued. Conversely, if an impaired person has a low BAC, they will then ask for a urine or blood sample. It is the officers' general impression

hours from time of driving. CRS 42-4-1301(2)(a.5) "Baby DUI" is a class A traffic infraction with adverse license consequences. 
that as the offense is a unified offense, the prosecutors feel if there is a good case for the alcohol, it is not necessary to pursue the drug violation; however, some officers still gather information for both and leave it to the prosecutor to decide how to argue the case.

The officers said turnaround time for having a sample analyzed ranged from five days to four weeks, and as Colorado does not have an administrative per se provision for drugs, that turnaround time is adequate. Some officers said samples would be analyzed first for alcohol, and if the BAC was .08 or higher, further analyses for drugs typically are not conducted. Samples may be sent to a State laboratory, a local department laboratory, or even some private providers. Some offices said a urine sample is preferred by the department because the cost of analysis is considerably less than for blood.

Officers generally felt there was no need for a drug per se law in Colorado, saying most DUID cases, particularly ones that involve a DRE or involve an experienced officer, are plead guilty and testimony is seldom required at trial. They say their current law allows for drug-impaired drivers to be prosecuted for driving "while impaired to the least degree."

When asked whether DUID cases were dropped in favor of more serious charges, such as drug possession at the felony level, some officers generally said both charges would be pursued; however, other officers said both charges would be handled in the courts on the same day, and often the DUID component would be dropped if a guilty plea was obtained for the felony drug possession charge. In the rare case that is contested, testimony from toxicologists is often required. The officers in general were quite supportive of the DRE program, and said they felt the volume of drugged driving cases was increasing and attributed that partly to increased availability of DREs.

\section{Summary of Prosecutorial Perspective}

Structured discussions were conducted with six prosecutors through four individual interviews and one involving two prosecutors in Colorado in an effort to develop an understanding of how DUID cases are handled in the courts. Colorado has an active DRE program, but does not have a drug per se law.

Generally, the prosecutors said DUID cases are relatively rare compared to DUI-alcohol cases and the majority of both categories of cases plead guilty prior to trial. When asked whether there were any special issues related to DUID cases, some saw no difference from alcohol cases, but others said proving drug impairment is more problematic. They felt developing probable cause for testing for drugs was not necessarily more difficult than alcohol, though they did say if a case goes to trial, they typically would need a toxicologist or DRE, if one participated in the investigation, to testify. They said the typical biological specimen obtained was urine, and test results generally arrived in time for the adjudication of criminal cases.

The prosecutors were mixed in their opinion as to whether a DRE was required to effectively make a case, though they universally said having a DRE evaluation made it easier to obtain a guilty plea. Most prosecutors said if a BAC above .08 was obtained, they did not bother with prosecuting the DUID component because either component is a violation of the same statute; however, some said they did pursue both components, particularly if it is in conjunction with a felony charge of distribution or possession of drugs. In that instance, the DUID offense would be typically plead away except for habitual traffic offenders. 
When asked about the general attitude of the court (judges) about the DUID offense, the prosecutors varied in their response. Some said it was the same as for the alcohol offense and others said specific drugs might make the judge take the case more seriously, and another said there were judges who were less concerned about marijuana. They felt conviction rates were similar between drug and alcohol cases. The prosecutors were very universally supportive of the DRE program and most felt it was an important component of dealing with drugged driving. One prosecutor felt having a drug per se law in Colorado would be helpful, but others were ambivalent about the need for such a statute.

\section{Data}

Data for DRE Evaluations for the State of Colorado were obtained from the National DRE Database. ${ }^{7}$ DUI arrest data were obtained from the FBI Arrest Statistics.

Table 9. Colorado's Summary Data on DUID and DUI Actions

\begin{tabular}{|c|c|c|c|c|c|}
\hline Year & $\begin{array}{c}\text { DRE } \\
\text { Evaluations }\end{array}$ & $\begin{array}{c}\text { DUID } \\
\text { Arrests* }^{*}\end{array}$ & $\begin{array}{c}\text { DUID } \\
\text { Convictions* }\end{array}$ & $\begin{array}{l}\text { DUID Lesser } \\
\text { Offense } \\
\text { Convictions }\end{array}$ & $\begin{array}{l}\text { DUI** } \\
\text { Arrests }\end{array}$ \\
\hline 2005 & 440 & & & & \\
\hline 2004 & 111 & & & & 24,848 \\
\hline 2003 & 23 & & & & \\
\hline 2002 & 5 & & & & \\
\hline 2001 & 2 & & & & 28,422 \\
\hline 2000 & 10 & & & & \\
\hline 1999 & & & & & 37,981 \\
\hline 1998 & & & & & 28,807 \\
\hline 1997 & & & & & 27,994 \\
\hline \multicolumn{6}{|l|}{1996} \\
\hline \multicolumn{6}{|l|}{1995} \\
\hline 1994 & & & & & 34,853 \\
\hline
\end{tabular}

Though available data is sparse, it appears that overall the number of DUI arrests is declining in the State, while the number of DRE evaluations is increasing in recent years. The lack of comprehensive statewide data on DUID is not surprising since, as in most States, the offense is integrated into the overall impaired-driving statute and the State and local record systems do not distinguish between alcohol and drug-impaired-driving offenses or convictions.

\footnotetext{
7 The database is currently maintained by PIRE for NHTSA under contract DNH22-02-D-9512, Task Order \#2.
} 


\section{West Virginia}

\section{State Without Drug Per Se Law and Without DRE Program}

West Virginia was a selected as a State without a drug per se statute or an active DRE program. Having a State that has neither of these specialized drugged driving features in its impaired-driving control system provides a basis of comparison with States with these features in their system.

\section{Summary of West Virginia's Drug Law}

Driving under the influence of any controlled substance or any drug or a combination of alcohol and any controlled substance or any drug is guilty of a misdemeanor. First offense is punishable by

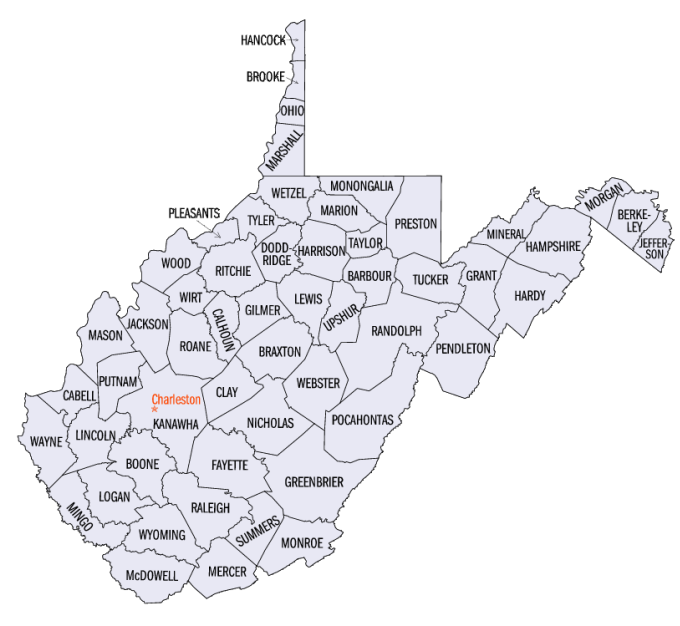

Figure 7. West Virginia 24 hours to 6 months imprisonment, $\$ 100$ to $\$ 500$ fine. License revocation for up to six months.

\section{Law}

West Virginia Code $§$ 17C-5-2.

(a) Any person who:

(1) Drives a vehicle in this State while he or she:

(A) Is under the influence of alcohol; or

(B) Is under the influence of any controlled substance; or

(C) Is under the influence of any other drug; or

(D) Is under the combined influence of alcohol and any controlled substance or any other drug; or

(E) Has an alcohol concentration in his or her blood of eight hundredths of one percent or more, by weight.

\section{Drug Specifics}

Any controlled substance or any drug combination of alcohol and any controlled substance or drug. 


\section{Statutory Sanctions}

Table 10. West Virginia Statutory Sanctions

\begin{tabular}{|c|c|c|c|c|c|}
\hline State & $\begin{array}{l}\text { Drug Per } \\
\text { Se Law } \\
\end{array}$ & $\begin{array}{c}\text { DRE } \\
\text { Program } \\
\end{array}$ & Effective Date & Law & Sanctions for First Offense \\
\hline \multirow{3}{*}{ WV } & \multirow{3}{*}{ No } & \multirow{3}{*}{ No } & & \multirow{3}{*}{$\begin{array}{l}\text { Driving under the } \\
\text { influence of any } \\
\text { controlled } \\
\text { substance or any } \\
\text { or drug or a } \\
\text { combination of } \\
\text { alcohol and any } \\
\text { controlled } \\
\text { substance or any } \\
\text { or drug is guilty of } \\
\text { a misdemeanor. }\end{array}$} & $\begin{array}{l}\text { Criminal: Minimum } 24 \text { hours to } 6 \\
\text { months imprisonment, } \$ 100 \text { to } \$ 500 \\
\text { fine for } 1 \text { st offense; } 6 \text { months to } 12 \\
\text { months, } \$ 1,000 \text { to } \$ 3,000 \text { for } 2 \text { nd } \\
\text { offense. }\end{array}$ \\
\hline & & & & & $\begin{array}{l}\text { Court-Ordered Other: Court costs and } \\
\text { surcharges may be imposed. }\end{array}$ \\
\hline & & & & & $\begin{array}{l}\text { Administrative: License revocation for } \\
\text { up to six months first offense, license } \\
\text { revocation for up to } 10 \text { years for } \\
\text { second offense and revocation for life } \\
\text { for third offense. }\end{array}$ \\
\hline
\end{tabular}

Criminal: Minimum 24 hours to 6 months imprisonment, $\$ 100$ to $\$ 500$ fine for first offense; 6 months to 12 months, $\$ 1,000$ to $\$ 3,000$ for second offense.

Court-Ordered Other: Court costs and surcharges may be imposed.

Administrative: License revocation for up to 6 months first offense, license revocation for up to 10 years for second offense and revocation for life for third offense. 


\section{Implementation and Handling of West Virginia's DUID Cases}

An officer must have probable cause developed by observing improper driving or an equipment violation in order to make the initial stop. If, in contact with the driver, reasonable suspicion of alcohol or drug impairment is developed, the officer pursues further investigation.

If the driver shows physical impairment and a low BAC, or there are obvious signs of drug use (drug paraphernalia, etc.) apparent, the driver is placed under arrest and the officer gathers further information.

Typically, the officer requests a blood sample from the driver and sends it to the State or local agency lab for analysis.

If drug results are positive, the officer may send them to the licensing agency, which can then administratively revoke the driver's license.

In case of refusal, the officer generally does not request a warrant to compel a test. The driver is cited and sanctioned for a chemical test refusal.

Prosecutors and police report most offenders plead guilty.

At trial, the presence of the drug and evidence for the stop and suspicion of drug use as well as proof of impairment are usually required to obtain a conviction.

Official records do not readily distinguish between the DUID and DUI-alcohol arrest and disposition.

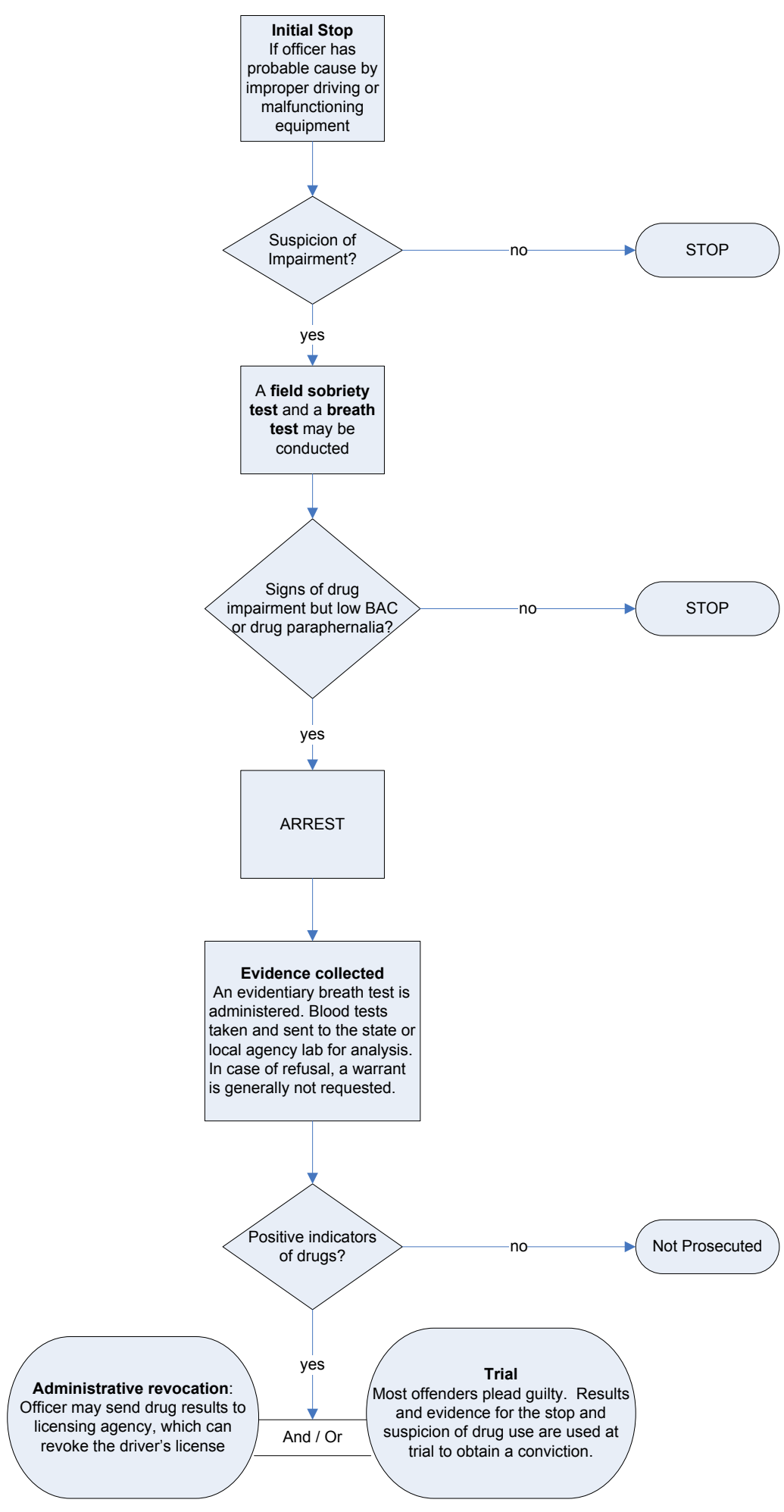

Figure 8. West Virginia Flowchart 


\section{Discussions With State and Local Officials}

The Governor's highway safety coordinator and a law enforcement liaison with the West Virginia Governor's Highway Safety Program were our principal points of contact and helped identify State and local officials who could provide information for this study.

We spoke with the director of driver services and the manager of driver improvement at the West Virginia DMV, who said their system is set up to handle the DUI-alcohol offense, but they are not aware of a code in the system for drugs. They said though their statute sets the alcohol administrative per se BAC at $.08 \mathrm{~g} / \mathrm{dL}$, they take administrative action on all those with BACs higher than .05. They also said they take administrative action on cases involving drugs alone.

We also met with two representatives from the State Police Forensic Lab, who reported its toxicology division does approximately 250 analyses per year for DUID. It primarily receives blood samples but also a few urine samples. The trend in recent years has been slightly fewer samples overall (either alcohol or drugs) coming in for analyses. However, the number of cases coming in for drug screen analyses has been on a reasonably steady increase. It currently has an approximate two-month turnaround to give analysis results to law enforcement, up from approximately a one-month turnaround in 2005. Its practice is to do the blood alcohol test first, and if the BAC is higher than .08, not to proceed with further drug testing.

\section{Summary of Law Enforcement Perspective}

We conducted two meetings in West Virginia with 14 police officers from Morgantown and Beckley. Additionally, we held a structured discussion with three other officers in Charleston. These discussions were held to develop an understanding of how the DUID laws were being implemented by law enforcement in West Virginia, which has no drug per se law or active DRE program. Participants involved officers from local police departments, sheriff's departments, and State police.

When asked to describe how a typical DUID case was developed, the officers said it was very similar to a DUI-alcohol case. First, they develop probable cause for the stop, either from erratic driving or other traffic violation. During the interview with the driver, they look for signs of impairment as they develop a reasonable suspicion. After having a driver get out of the car, they do SFST tests; impairment is determined through that process. They said in certain areas of the State, they encounter drivers who seem to be drug-impaired fairly frequently, and when they request a blood sample for a drug test, it is very seldom refused. Some officers reported using preliminary breath testers in the arrest process. Often drug use is suspected because the officer observes drug paraphernalia or because of the suspect's reaction during the arrest process. Also, seemingly impaired drivers who test low on the breath alcohol test trigger a more thorough investigation of drug use.

Officers generally said they could not compel people to give blood tests. Some officers said many other officers were reluctant to pursue DUID charges because they are not well trained in that area and might be embarrassed in court. Most offenders seemed to cooperate in providing a blood sample. One officer said in his county, the Circuit Court judge authorized obtaining search warrants to get blood draws for DUID offenses from offenders who refuse. Another officer said procedure is followed in about 21 of the 55 counties in the State. One State Police officer said if an offender refused, because the law required taking the test within 2 hours, he would generally 
just try to find a safe ride home for the individual rather than seek a warrant because he could not get the blood draw done quickly enough. A municipal police officer said the 2-hour time period was not a problem for him because backup officers would take care of other aspects of the arrest procedure such as towing the vehicle while he prepared the warrant, contacted the judge and got the blood drawn done. The officers' estimate of the turnaround time for blood test results from the State laboratory varied from 3 to 6 months. Those who said 3 months said timing was in synch with the court schedule and not a problem. Some officers reported they were able to get the hospital test results of blood and use as evidence in trials as well. The officers generally reported if a person tested at .08 or above they did not pursue the drug aspect of the case even for those they suspected of having drugs involved. The officers varied in the extent to which they thought DUID cases pled guilty, some indicating DUID was more likely to result in a trial than DUI-alcohol and others saying most defenders pled guilty to either offense. One officer said in terms of evidence videotaping of the arrest process is probably the best thing one could have. For people who refused and for whom the officer did not obtain a warrant, it demonstrated the impairment. The officers uniformly said even if there are frustrations with the courts, the DMV applied administrative sanctions to DUID offenders as well as DUI-alcohol offenders. The officers felt DUID arrests have been rising over time, predominantly in the southern and western part of the State where the officers perceive there are more drug problems. As in many other States, he officers said DUID and DUI-alcohol offenses appear under the same section of the law, and the computerized records do not distinguish between alcohol and drug cases.

\section{Summary of Prosecutorial Perspective}

Discussions were held individually with six West Virginia prosecutors about the handling of DUID cases. They said drugged driving cases were relatively rare. When asked if there were any special issues related to DUID cases, one prosecutor said a DRE was needed; however, he said West Virginia has none. Others said evidence of drugs from crash-involved drivers was difficult to obtain because of chain of custody issues when obtaining samples from hospitals.

Most prosecutors felt DUID cases were no more likely to be contested by the offender than DUIalcohol cases. They were mixed in their response as to whether it was more difficult to develop probable cause. In general, the prosecutors said in contested cases expert testimony from a lab specialist was necessary. Generally, they felt there were delays in obtaining laboratory test results.

The general feeling was if a BAC above .08 was obtained, drugs were either not pursued by the officers or not pursued in the prosecution because both components of the offense are within the same statute.

Most prosecutors said a DUID case would not be dismissed to obtain a plea for a drug possession or distribution offense, except one prosecutor said a felony drug offense would be pursued over a misdemeanor DUID. One prosecutor felt DUID offenders were much less likely to plead guilty to the offense than DUI-alcohol. The others said they had so few cases they had no opinion on issue. The prosecutors did not indicate awareness of any changes in the patterns of disposition of DUID cases in recent history. In terms of police officers looking for DUID offenders, one prosecutor felt because there are difficulties with prescription drug abuse in the southern part of West Virginia, officers there are more attuned to the DUID case. Others did not think there was a special interest in issue on the part of police officers. 


\section{Data}

West Virginia does not distinguish in its data systems between DUI arrests or convictions based on the presence of drugs, alcohol, or the combination thereof. Thus it is not possible to objectively address the extent to which DUID arrests or convictions may have changed in recent years. DUI arrest statistics were obtained from the West Virginia DMV 2007 Annual Report.

Table 11. West Virginia's Summary Data on DUID and DUI Actions

\begin{tabular}{|c|c|c|c|c|c|}
\hline Year & $\begin{array}{c}\text { DRE } \\
\text { Evaluations* }\end{array}$ & $\begin{array}{c}\text { DUID } \\
\text { Arrests* }\end{array}$ & $\begin{array}{c}\text { DUID } \\
\text { Convictions* }\end{array}$ & $\begin{array}{l}\text { DUID Lesser } \\
\text { Offense } \\
\text { Convictions* }\end{array}$ & $\begin{array}{c}\text { DUI } \\
\text { Arrests }\end{array}$ \\
\hline 2007 & & & & & 10,004 \\
\hline 2006 & & & & & 10,010 \\
\hline 2005 & & & & & 9,666 \\
\hline 2004 & & & & & 8,813 \\
\hline 2003 & & & & & 8,206 \\
\hline 2002 & & & & & 8,973 \\
\hline 2001 & & & & & 9,546 \\
\hline \multicolumn{6}{|l|}{2000} \\
\hline 1999 & & & & & \\
\hline
\end{tabular}




\section{lowa}

\section{State With Drug Per Se Law and DRE Program}

Iowa was selected as a State for more in-depth study because it has both a drug per se law and an active DRE program, thus providing an opportunity examine how the law functions where there is likely to be fairly aggressive DUID enforcement and DRE officers may be available to assist other officers in case evaluation and court testimony. Iowa reported having approximately 125 active DRE officers.

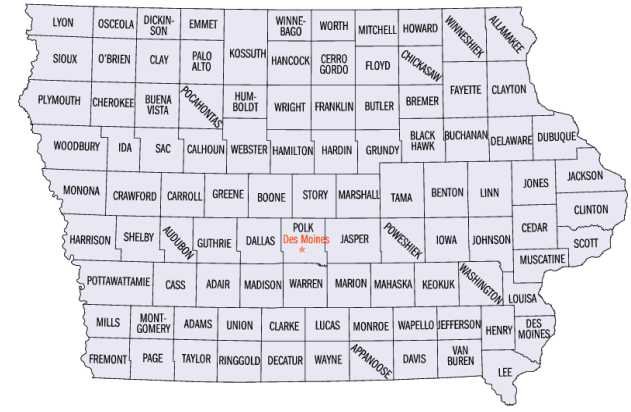

Figure 9. lowa

\section{Summary of lowa's Drug Per Se Law}

Iowa has a zero tolerance per se drugged driving law enacted for any drug or controlled substance (cannabis metabolites are excluded under the law) (Iowa Code Section 321J.2).

Iowa's law calls for not more than 1 year (48-hour mandatory imprisonment), and 180 days (90 days mandatory) license revocation for first per se offense.

\section{Effective Date}

Iowa's drug per se law took effect on July 1, 1998.

\section{Drug Per Se Law}

\section{Iowa Code § 321J.2. Operating while under the influence of alcohol or a drug or while having an alcohol concentration of .08 or more (OWI).}

1. A person commits the offense of operating while intoxicated if the person operates a motor vehicle in this State in any of the following conditions:

a. While under the influence of an alcoholic beverage or other drug or a combination of such substances.

b. While having an alcohol concentration of .08 or more.

c. While any amount of a controlled substance is present in the person, as measured in the person's blood or urine.

7a. This section does not apply to a person operating a motor vehicle while under the influence of a drug if the substance was prescribed for the person and was taken under the prescription and in accordance with the directions of a medical practitioner as defined in chapter $155 \mathrm{~A}$ or if the substance was dispensed by a pharmacist without a prescription pursuant to the rules of the board of pharmacy examiners, if there is no evidence of the consumption of alcohol and the medical practitioner or pharmacist had not directed the person to refrain from operating a motor vehicle.

b. When charged with a violation of subsection 1, paragraph "c," a person may assert, as an affirmative defense, that the controlled substance present in the person's blood or urine was prescribed or dispensed for the person and was taken in accordance with the 
directions of a practitioner and the labeling directions of the pharmacy, as that person and place of business are defined in section 155A.3.

\section{Drug Specifics}

Any drug or controlled substance.

\section{Statutory Sanctions}

Table 12. lowa Statutory Sanctions

\begin{tabular}{|c|c|c|c|c|c|}
\hline State & $\begin{array}{l}\text { Drug Per } \\
\text { Se Law }\end{array}$ & $\begin{array}{c}\text { DRE } \\
\text { Program }\end{array}$ & $\begin{array}{c}\text { Effective } \\
\text { Date }\end{array}$ & Law & Sanctions for First Offense \\
\hline IA & Yes & Yes & July 1, 1998 & $\begin{array}{l}\text { lowa has a zero } \\
\text { tolerance per se } \\
\text { drugged driving law } \\
\text { enacted for any drug } \\
\text { or controlled } \\
\text { substance (cannabis } \\
\text { metabolites are } \\
\text { excluded under the } \\
\text { law) (lowa Code } \\
\text { Section 321J.2). }\end{array}$ & $\begin{array}{l}\text { Criminal: For the } 1 \text { st offense: serious } \\
\text { misdemeanor. Not more than } 1 \text { year in } \\
\text { jail, with } 48 \text { hours mandatory; } \$ 1,000 \\
\text { mandatory fine, with possibility of } \\
\text { waiving } \$ 500 \text { if no injury to people or } \\
\text { property and the possibility of waiving } \\
\text { the remaining } \$ 500 \text { if the defendant } \\
\text { proves installation of an ignition } \\
\text { interlock device after the initial "hard" } \\
\text { suspension. In addition, defendants } \\
\text { must submit to a substance abuse } \\
\text { evaluation and treatment and complete } \\
\text { a course for drinking drivers. } \\
\text { Court-ordered Other: Community } \\
\text { service may be ordered in lieu of fines. } \\
\text { Deferred judgment is possible for a } 1 \text { st } \\
\text { offense. Restitution and surcharge on } \\
\text { fines imposed and drug education } \\
\text { course may be imposed. } \\
\text { Administrative: License revocation: } 180 \\
\text { days ( } 90 \text { days mandatory) revocation } \\
\text { for } 1 \text { st per se offense; } 180 \text { days ( } 30 \\
\text { days mandatory) to } 1 \text { year revocation } \\
\text { for } 1 \text { st DUl offense. }\end{array}$ \\
\hline
\end{tabular}

Iowa makes no distinction between "under the influence" per se alcohol or per se controlled substances for criminal sentencing. As a result, even drug cases require the use of an ignition interlock by convicted offenders. In addition, any prior offense (whether, under the influence, per se alcohol, or per se controlled substances) which has occurred within the 12-year look-back period may be used to enhance a pending offense. Therefore, a prior "alcohol" case makes a current "per se controlled substances" case a second offense.

Criminal: For the first offense- serious misdemeanor. Not more than 1 year in jail, with 48 hours mandatory; $\$ 1,000$ mandatory fine, with possibility of waiving $\$ 500$ if no injury to people or property and the possibility of waiving the remaining $\$ 500$ if the defendant proves installation of an ignition interlock device after the initial "hard" suspension. In addition, defendants must submit to a substance abuse evaluation and treatment and complete a course for drinking drivers. 
Second offense within 12 years- aggravated misdemeanor. Not more than 2 years in prison or 1 year in jail, with 7 days mandatory; $\$ 1,500$ mandatory fine, with a maximum fine of $\$ 5,000$ and no "waiver" provision. In addition, defendants must submit to a substance abuse evaluation and treatment and complete a course for drinking drivers.

Third and subsequent offense within 12 years- class D felony. Not more than 5 years in prison or, if prison term is suspended, not less than 30 days in jail; $\$ 2,500$ mandatory fine, with a maximum fine of $\$ 7,500$ with no "waiver" provision. In addition, defendants must submit to a substance abuse evaluation and treatment and complete a course for drinking drivers.

Court-ordered other: Community service may be ordered in lieu of fines. Deferred judgment is possible for a first offense. Restitution and surcharge on fines imposed and drug education course may be imposed.

Administrative: license revocation- 180 days (90 days mandatory) revocation for first per se offense; 1 year (mandatory) revocation for second or subsequent offense within 12 years; 180 days (30 days mandatory) to 1 year revocation for first OWI offense; 2 years ( 1 year mandatory) revocation for second offense within 12 years; 6 years (1 year mandatory) for third or subsequent offense. $^{8}$

\footnotetext{
${ }^{8}$ Adapted from Walsh, Danziger, Cangianelli, \& Koehler, 2002; see References. Modified by authors of this
} document on December 7, 2006. 


\section{Implementation and Handling of lowa's OWID Cases}

An officer must have probable cause developed by observing improper driving or equipment violation in order to make the initial stop. If, in contact with the driver, reasonable suspicion of alcohol or drug impairment is developed, the officer gathers further investigation.

If the driver shows physical impairment and a low BAC, or there are obvious signs of drug use (drug paraphernalia, etc.) apparent, the driver is arrested and further information is gathered. The low BAC is generally determined through the results of a preliminary breath test (PBT) administered after the field sobriety test.

A DRE may be called in to do an evaluation or the arresting officer may gather additional information.

Drug investigations are generally not conducted if the BAC is above $.08 \mathrm{~g} / \mathrm{dL}$.

Typically, urine samples are obtained at the evidential testing facility and sent to the State or local agency lab for analysis. The officer requests blood samples if inhalants or hallucinogens are suspected.

If drug results are positive, the officer may send them to the licensing agency, which can then administratively revoke the driver's license.

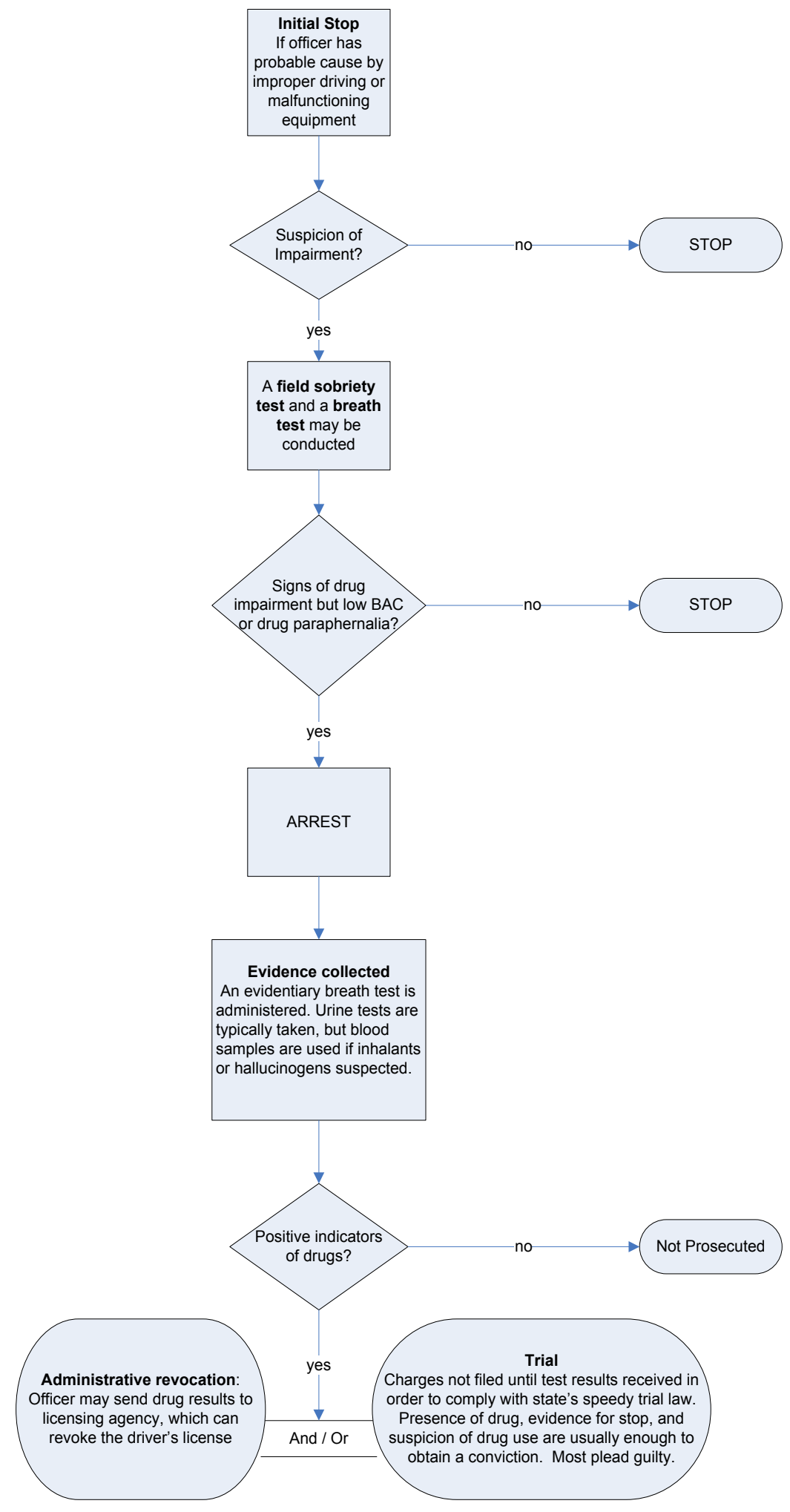

Figure 10: lowa Flowchart 
Administrative per se documents and criminal charges are not filed until the test results are received in order to comply with Iowa's speedy trial law.

At trial, the presence of the drug and evidence for the stop and suspicion of drug use are usually required to obtain a conviction. However, in most cases defendants plead guilty. Some prosecutors are reluctant to pursue prescription drug cases unless impairment is evident.

OWI-D charging and conviction data are available through the Iowa Justice Data Warehouse.

\section{Discussions With State and Local Officials}

To obtain a statewide perspective of Iowa's drug per se law and its implementation, we held a discussion with the Governors Traffic Safety Bureau, the State DRE coordinator, and two law enforcement officers. This group said Iowa had an active DRE program and, since 1991, 180 officers had been trained. The group felt the adoption of the drug per se law in 1998 had been a positive move in that the per se facet of the law worked well for drugs, both in terms of obtaining convictions in court, and in ensuring appropriate license sanctions were applied through the administrative per se procedures. We spoke to the Assistant Attorney General, who also serves as the Prosecuting Attorneys Training Coordinator. He reiterated that the drug per se law is a true per se law, and any amount of a per se drop triggers the same level of sanction as the illegal alcohol level of .08. He did indicate that, though it was a per se law, an officer needs to be able to establish grounds for impairment to validly request a test. Iowa has a speedy indictment rule that calls for filing an information "charge" within 45 days of arrest. After charging, the clock begins a 90-day period within which the trial must be conducted under the speedy trial rule. Since it sometimes takes a long period of time to obtain the analysis results on drug specimens, prosecutors are encouraged to delay filing the information until near the end of the initial 45-day period so test results will be available at the time of trial. It was his opinion the DRE program and the per se law were complementary in nature, because the DRE can help provide reasonable grounds of impairment to request a test. He reported warrants for compelling chemical tests are only issued for crash cases involving death or serious injury. He also reported that though there is a strong DRE program in Iowa, the majority of the OWID arrests are still made by non-DRE officers. He said the OWID offense was the same as the other impaired-driving offenses, in terms of where they reside in the statutes, and the conviction data for the drug offense alone may be difficult to identify. It was his opinion the proportion of drugged-driving cases that went to trial was much lower than that for alcohol-based cases. Conversations were also held with personnel in the DMV Records Division. They said that though they have an excellent data system, it is currently not geared towards discriminating between OWID and OWIA cases.

\section{Summary of Law Enforcement Perspective}

In order to develop an understanding of law enforcement officers' perspective of enforcing the OWID per se law in Iowa, we conducted two meetings - one in Cedar Rapids and one in Des Moines - that involved a total of 9 officers representing local police departments, sheriff's offices, and the State patrol. Several of these officers were DRE trained. Iowa had 123 DREs as of 2004 and, according to the IACP, 112 DREs at the end of 2007.

A typical arrest sequence involved a stop based on probable cause for a traffic violation, followed by the officer developing a suspicion of impairment and conducting field sobriety tests. Most arrests involved the officer administering a breath test after the SFSTs. If the BAC is low, 
yet impairment has been demonstrated, the officer will call for a DRE officer and if one is close by, the DRE will come to the scene, though more frequently the officer would meet the DRE at the police station. If a DRE is not available, officers do pursue the OWID arrest on their own. It is their impression the majority of OWID arrests are made without benefit of DREs. They said DRE-handled arrests had a confirmation rate of approximately $95 \%$ from the lab tests, whereas non-DRE arrests had approximately a 50-percent confirmation rate.

With the exception of cases where the use of inhalants or hallucinogens is suspected by the DRE, they almost exclusively rely on urinalysis to determine the presence of illegal drugs. Blood samples are used in those cases involving suspected use of inhalants or hallucinogens. In most jurisdictions, urine samples are sent to the State lab, though some larger jurisdictions use the local hospital lab. In those instances, the officers reported test results were available within 1 to 7 days, whereas tests sent to the State lab may not come back for up to 60 days. Iowa has a speedytrial law, so charges are not filed for the OWID offense until the test results are available.

Iowa is an administrative drug per se State, but the officers reported they do not confiscate the license until they know the result of laboratory tests for arrestees who are below $.08 \mathrm{~g} / \mathrm{dL}$ but have been tested for drugs. Several officers reported that, in that case, they would release the individual, saying they would call when test results came back to the officer. At that time, the officer would have the individual come in and finish paperwork for the administrative procedures. The officers reported this procedure worked well and most people did come back in. If not, the paperwork is sent to the DMV and the DMV sends a notice of revocation to the offender. The offender's license is then revoked by the State so that if stopped later, the offender's suspended license is discovered by the stopping officer.

The officers, even DRE officers, said if an offender had an illegal BAC, it was unlikely investigation of the drug component of the offense would take place. They also said OWID cases were much less likely to result in trials than OWI-alcohol cases. The officers reported they routinely receive notification of the toxicology test results and case disposition.

The officers reported there was a 1-day course offered to them to sensitize them to drugged driving issues. They felt the course would be more helpful if it lasted at least 2 days and had components in it that involved testing the officers on their knowledge about OWID. They said prosecutors generally did not plea-bargain away OWID cases in favor of drug possession or distribution charges. However, they said in a situation like that, the prosecutor would typically consult with the arresting officer.

\section{Summary of Prosecutorial Perspective}

Structured discussions were held by telephone with six Iowa prosecutors from across the State to gain an understanding of how they prosecute OWID offenses. They all said OWID cases constituted a fraction of their impaired-driving cases, generally $10 \%$ or less. One prosecutor said the OWID cases the prosecutors handled were more likely to involve death or serious circumstances crashes. In addition, another said the officers' field tests were different for OWID cases than for OWI-alcohol cases. Generally, the prosecutors felt OWID cases were less likely to be contested than alcohol cases, though some felt it was more difficult to develop probable cause when arguing those cases. Typically, they report the need to have the officer available for prosecution and chain of custody for biological samples, and more rarely a laboratory specialist. DRE officers were mentioned by two of the six prosecutors as being important for prosecuting the case in court. 
There were mixed responses in terms of whether laboratory test results were available in a timely manner, with one prosecutor reporting persistent problems in that regard, another indicating they use a local laboratory to obviate the problem, and the others feeling currently they get the test results quickly enough to be able to meet Iowa's 90-day deadline after charging for conducting the trial. They generally reported the test results only needed to indicate the detectable level of the presence of the substances, but for jury cases quantification would be helpful. Most said urine was the most frequently used specimen for these tests.

In terms of the use of DREs, two of the six prosecutors said they really needed one to obtain convictions, but the others said DRE testimony was not necessary. In general, the prosecutors said if a BAC of .08 or above was obtained, the drug aspect would not be pursued, particularly because both alcohol and drugs are components of the same statutory offense.

When asked whether OWID cases were plea-bargained away for possession or drug distribution guilty pleas, only two of the prosecutors said it happened, and rarely at that. In general, the prosecutors said OWID cases were as likely or slightly less likely to plead guilty than alcohol cases.

When asked if a drug driving offense results in an enhanced sanction over alcohol offenses, one prosecutor said for a BAC less than .15, deferred judgment was available, but not for the OWID component of the offense. None of the prosecutors indicated knowledge of any changes over time in patterns of dispositions of the OWID offense. When asked if the per se law resulted in changes in conviction patterns, the general reaction of the prosecutors was it had increased the charging and conviction for OWID in that urine samples were more likely to be requested now, unless the presence of alcohol was overwhelming. Prosecutors varied in their estimate of the proportion of OWID cases that result in a trial. One said possibly 10 to $25 \%$ did, whereas the rest said it was very low, less than $5 \%$. Two of the prosecutors said the per se law has made it easier to prosecute the OWID cases, but three said it had not effected any change. They generally said there was less of a need to prove impairment, but one said one needs to prove it in order to request the test. They unanimously agreed there are no lesser-included offenses. Generally, the prosecutors felt the DEC program was a positive one, and in general felt police officers were more sensitive to drugged driving since the passage of the per se law, and officers were well aware of the legislation, and the general public less so.

\section{Data}

Data for DRE evaluations in Iowa were obtained from the National DRE Database. Iowa's DRE coordinator indicated that there were 123 certified DREs active in the State in 2004. The IACP indicated that in 2007, there were 112 active DREs in the State. DRE data were only available from 2001 to the present. OWI-Alcohol (OWI-A) arrest and conviction data were obtained from the Iowa Justice Data Warehouse. OWI-Drug (OWI-D) arrests are an estimate based on biological samples submitted to the Iowa Division of Criminal Investigation (DCI) for analysis. 
Table 13. lowa's Summary Data on OWID and OWID Actions

\begin{tabular}{|c|c|c|c|c|c|}
\hline Year & $\begin{array}{c}\text { DRE } \\
\text { Evaluations }\end{array}$ & $\begin{array}{c}\text { OWID } \\
\text { Arrests* }\end{array}$ & $\begin{array}{c}\text { OWID } \\
\text { Convictions }\end{array}$ & $\begin{array}{l}\text { OWI-A } \\
\text { Arrests }\end{array}$ & $\begin{array}{c}\text { OWI-A } \\
\text { Convictions }\end{array}$ \\
\hline 2005 & 49 & 1,265 & & 17,254 & 13,673 \\
\hline 2004 & 297 & 1,054 & & 17,398 & 13,435 \\
\hline 2003 & 483 & 1,234 & & 15,064 & 11,756 \\
\hline 2002 & 714 & 1,160 & & 15,544 & 12,703 \\
\hline 2001 & 513 & 964 & & 14,929 & 12,248 \\
\hline 2000 & & 1,153 & & 15,892 & 12,790 \\
\hline 1999 & & 880 & & 16,945 & 13,439 \\
\hline $1998^{* * *}$ & & 686 & & & \\
\hline 1997 & & 368 & & & \\
\hline 1996 & & 586 & & & \\
\hline
\end{tabular}

Data presented in Table 13 shows the volume of samples submitted to the DCI from OWID arrests have increased since the effective date of Iowa's drug per se law on July 1, 1998. In FYs 1996 and 1997 together, the two years before the law took effect, 954 OWID arrests were reported, and 600 of these samples $(62.9 \%)$ tested positive for prohibited drugs. For the first two years after the law went into effect (FYs 1998 and 1999), 1,566 samples resulted in 1,069 positive test results (68.3\%). OWI-A data were only available for 1999 to the present, so we were not able to assess the difference in OWI-A rates before and after the drug per se law went into effect. 


\section{Wisconsin}

\section{State with Drug Per Se Law and DRE Program}

Wisconsin was selected as a State for more in-depth study because it is a State with both a drug per se law and an active DRE program, thus providing an opportunity to examine how the law functions where there is likely to be fairly aggressive OUID enforcement and DRE officers may be available to assist other officers in case evaluation and court testimony.

\section{Summary of Wisconsin's Drug Per Se Law}

Wisconsin has a zero tolerance per se drugged-driving law enacted for any detectable amount of a restricted controlled substance in the person's blood (Wisconsin Statutes Section

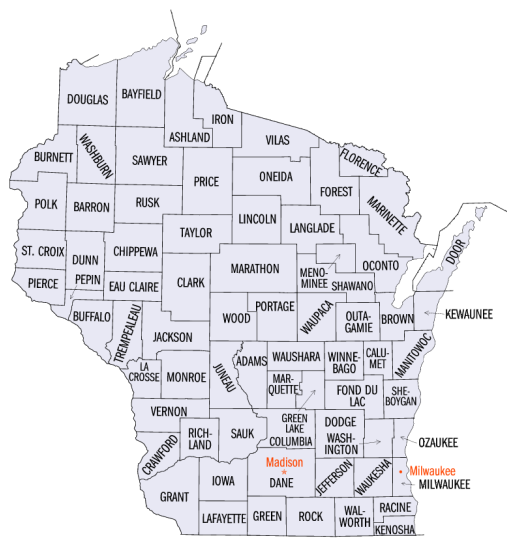

Figure 11. Wisconsin 346.63). Restricted controlled substances are defined as Schedule I controlled substances (cannabis metabolites are excluded), methamphetamine and cocaine (cocaine metabolites are included). A valid prescription for methamphetamine or one of its metabolic precursors, gammahydroxybutyric acid or delta-9-tetrahydrocannabinol, can be an affirmative defense.

For a first offense, Wisconsin law calls for no imprisonment but up to a $\$ 300$ fine ( $\$ 150$ mandatory) for first offense, and 6 to 9 months license revocation.

\section{Effective Date}

Wisconsin's drug per se law took effect on December 19, 2003.

\section{Drug Per Se Law}

\section{Wis. Stat. § 346.63(1)(a). Operating under influence of intoxicant or other drug}

(1) No person may drive or operate a motor vehicle while:

(a) Under the influence of an intoxicant, a controlled substance, a controlled substance analog or any combination of an intoxicant, a controlled substance and a controlled substance analog, or under the influence of any other drug to a degree which renders him or her incapable of safely driving, or under the combined influence of an intoxicant and any other drug to a degree which renders him or her incapable of safely driving; or

\section{Wis. Stat. $\$ 346.63(1)(\mathrm{am})$. Operating with a restricted controlled substance.}

(1) No person may drive or operate a motor vehicle while:

(am) The person has a detectable amount of a restricted controlled substance in his or her blood.

\section{Drug Specifics}

Restricted controlled substances are defined as Schedule I controlled substances (cannabis metabolites are excluded), methamphetamine and cocaine (cocaine metabolites are included). A valid prescription for methamphetamine or one of its metabolic precursors, gammahydroxybutyric acid or delta-9-tetrahydrocannabinol can be an affirmative defense. 


\section{Statutory Sanctions}

Table 14. Wisconsin Statutory Sanctions

\begin{tabular}{|c|c|c|c|c|c|}
\hline State & $\begin{array}{l}\text { Drug Per } \\
\text { Se Law }\end{array}$ & $\begin{array}{c}\text { DRE } \\
\text { Program } \\
\end{array}$ & Effective Date & Law & Sanctions for First Offense \\
\hline WI & Yes & Yes & $\begin{array}{l}\text { December 19, } \\
2003\end{array}$ & $\begin{array}{l}\text { Wisconsin has a } \\
\text { zero tolerance per } \\
\text { se drugged driving } \\
\text { law enacted for } \\
\text { controlled } \\
\text { substances, } \\
\text { controlled } \\
\text { substance analogs } \\
\text { or any other drug } \\
\text { (cannabis } \\
\text { metabolites are } \\
\text { excluded) } \\
\text { (Wisconsin } \\
\text { Statutes Section } \\
346.63 \text { ). A } \\
\text { prescription for } \\
\text { cannabis, } \\
\text { methamphetamine } \\
\text { or GHB can be an } \\
\text { affirmative defense. }\end{array}$ & $\begin{array}{l}\text { Criminal: No imprisonment, } \$ 150 \\
\text { (mandatory) to } \$ 300 \text { fine for } 1 \text { st offense. A } \\
\$ 350 \text { surcharge is added on all OWI } \\
\text { offenses. Penalties are enhanced if great } \\
\text { bodily harm under sec } 940-25(1) \text { is } \\
\text { involved. } \\
\text { Court-Ordered Other: The court may order } \\
\text { intermittent periods of confinement or } \\
\text { electronically monitored home detention in } \\
\text { lieu of imprisonment, and/or community } \\
\text { service in lieu of or in addition to jail and } \\
\text { fines. The court may also order a } \\
\text { defendant to pay restitution directly to a } \\
\text { victim or to participate in a visitation } \\
\text { program, and must assess certain } \\
\text { surcharges against the defendants. } \\
\text { Administrative: } 6 \text { months to } 9 \text { months } \\
\text { revocation for } 1 \text { st offense; } 1 \text { year ( } 60 \text { days } \\
\text { mandatory) to } 2 \text { years revocation for an } \\
\text { injury-related DUl offense; } 2 \text { years (120 } \\
\text { days mandatory) revocation for a great } \\
\text { injury-related DUl offense. }\end{array}$ \\
\hline
\end{tabular}

Criminal: No imprisonment, $\$ 150$ (mandatory) to $\$ 300$ fine for first offense (first offense is civil, not criminal); 5 days (mandatory) to 6 months, $\$ 350$ (mandatory) to $\$ 1,100$ for second offense within 10 years; 30 days (mandatory) to 1 year, $\$ 600$ (mandatory) to $\$ 2,000$ for third offense; 60 days (mandatory) to 1 year, $\$ 600$ (mandatory) to $\$ 2,000$ for fourth offense; 6 months (mandatory) to 5 years, $\$ 600$ (mandatory) to $\$ 2,000$ for fifth and subsequent offenses. A $\$ 350$ surcharge is added on all OWI offenses. Penalties are enhanced if great bodily harm under sec 940-25(1) is involved.

Court-Ordered Other: The court may order intermittent periods of confinement or electronically monitored home detention in lieu of imprisonment, and/or community service in lieu of or in addition to jail and fines. The court may also order a defendant to pay restitution directly to a victim or to participate in a visitation program, and must assess certain surcharges against the defendants.

Administrative: 1 year revocation (after 30 days, driver is eligible for a restricted license) for first refusal; 2 years revocation (after 90 days, a restricted license is possible) for second refusal within 10 years; 3 years (after 120 days, a restricted license is possible) revocation and possible vehicle forfeiture for third or subsequent refusals. 


\section{Implementation and Handling of Wisconsin's OUID Cases}

An officer must develop probable cause by improper driving or equipment violation in order to make the initial stop. If, in contact with the driver, reasonable suspicion of alcohol or drug impairment or use of a restricted controlled substance is developed, the officer gathers further information.

If the driver shows physical impairment and a low BAC, or there are obvious signs of drug use (drug paraphernalia, etc.) apparent, the driver is arrested and the officer gathers further information.

A DRE may be called in to do an evaluation or the arresting officer may gather additional information.

Blood samples are taken and sent to the State or local agency lab for analysis. If drug testing is requested and the $\mathrm{BAC}$ is above .10 , analysis for drugs is typically not conducted.

If drug results are positive for one or more restricted controlled substances, the officer may send them to the licensing agency, which can then administratively revoke the driver's license.

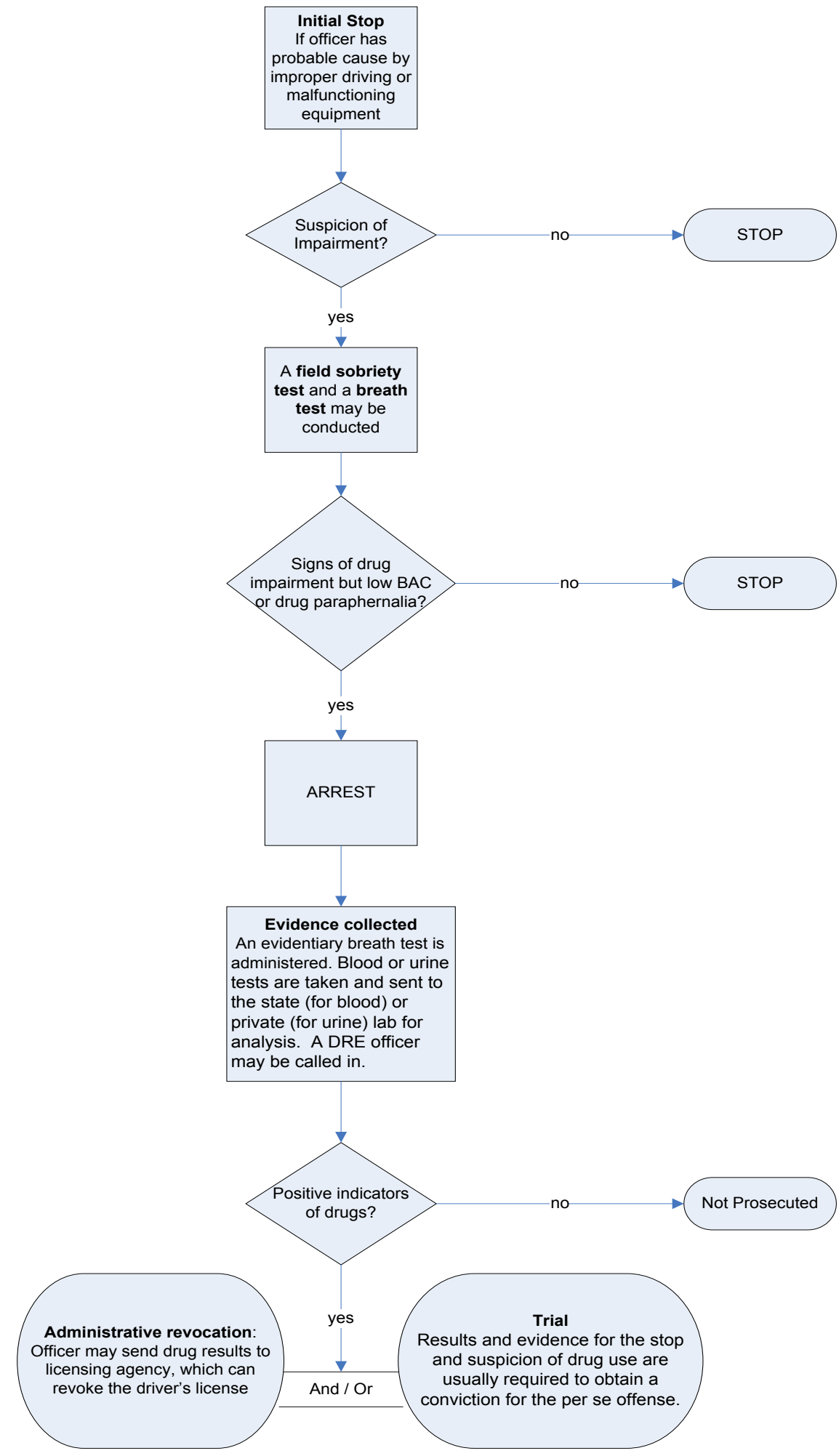

Figure 12. Wisconsin Flowchart 
At trial, the presence of the restricted controlled substance and evidence for the stop and suspicion of drug use are usually required to obtain a conviction, though in some cases, they still are required to prove impairment. Evidence of impairment and testimony regarding the drugs found and their ability to cause impairment are needed for non-restricted controlled substance OUID cases.

Wisconsin's official records do not readily distinguish between the OUID and OUI-alcohol arrest and disposition.

\section{Summary of Law Enforcement Perspective}

Three discussion groups were held with law enforcement officers near Milwaukee and Madison, Wisconsin. The discussion that took place at the Waukesha State Patrol Post included four people: a shift command sergeant, the two Wisconsin State Patrol officers with the highest OUID arrests, and a community police officer from the Waukesha Police Department. The Brookfield Police Department group consisted of five officers and a sergeant. Only two of those five had done OUID arrests before. The Deforest Post discussion group had five participants: four from the Wisconsin State Patrol and one from the Dane County Sheriff's Department.

The participants said a typical OUID case begins with the observation of a vehicle driving in suspicious manner, such as erratic driving, speeding, weaving, or slowing down. The cause for this could be bad vision, age, a medical problem, or impairment. After the initial assessment and observations, the officer proceeds to a SFST. The results of this test determine whether a preliminary breath test is given. If the PBT indicates a presence of alcohol, then the suspect is arrested and taken to the patrol station for an Intoximeter test. The suspect is then taken to jail or released to a responsible party. If no alcohol is present, the officer must determine if drugs are present. This can be done by questioning and talking to the individual, checking the eyes, observing an odor from drug use, observing eyelid or body tremors, or observing a white or green coating on the tongue, among other indicators.

DREs are sometimes called in after the arrest to conduct physical and psychomotor tests. Some interviewed officers had experience as DREs. Their evaluation is helpful because it tells the toxicology lab which drug classes to test for, but a DRE is not essential in making the drug arrest. Possession or distribution charges can result from the officer finding drugs, pill bottles, or paraphernalia in the car. Officers do not drop one charge for another, but pursue both the OUID and possession/distribution charges. None of the participants of this discussion had ever been to court on an OUID.

The charge can be for prescription, over-the-counter, or illegal drugs. In the experience of the interviewed officers, people are generally very forthcoming about their prescription drug use because they believe it is legal to drive while using them.

Blood is the only true test for drug impairment, and is preferred by these officers over other sample types for testing alcohol impairment as well. Blood collection is done at the nearest hospital by a trained technician or phlebotomist. Some districts may force blood collection from suspects, but this depends on each individual district attorney. There are four laboratories around the State, but all the officers in this discussion said their samples were sent to the Wisconsin State Laboratory of Hygiene, in Madison. There is an option on the transmittal form the officer may select, indicating not to test for drugs if the BAC is above a certain level, usually between .08 and .14. Blood results are slow to get back; officers report waiting between two and six 
months to get the results of blood drug tests from their arrests, but only two to six weeks to get results for alcohol tests.

\section{Summary of Prosecutorial Perspective}

In order to develop an understanding of prosecutors' perspective on Wisconsin's drug per se law, we conducted structured individual discussions with nine prosecutors with experience prosecuting OUID cases.

In general, the prosecutors felt OUID cases were somewhat more likely to be contested, particularly those which involve prescription drugs because the offenders feel the use is justified and claim they may not have been warned the drug is a potential problem. The prosecutors said little difficulty in developing probable cause for drawing the blood sample, which is the only biological medium used for drug analysis in Wisconsin, though they said cases involving DREs or experienced officers went more smoothly in that regard. They said if a case is contested in court, they often needed the phlebotomist as well as the lab analyst and the arresting officer for testimony. Their estimates of how long it takes to get the blood test results varied from two to six months, but did not say this presents a problem in terms of prosecution. A DRE was not reported to be necessary to make a case; however, it was said they were helpful.

When asked if they prosecuted both the drug component and the alcohol component of cases above .08, the prosecutors said the lab did not test for drugs other than alcohol if the BAC was above .10 unless specially requested, but if evidence on both drugs and alcohol were available, they were both presented. An example might be special circumstances such as a homicide or great bodily harm case. Both alcohol and drugs are components of the same general offense, so the motivation for trying the case on each element is just to ensure conviction. The penalty is the same for both alcohol and drugs.

The prosecutors said unanimously they do not dismiss an OUID case in favor of a guilty plea of possession or distribution of drugs. No clear pattern appeared in their report of whether OUID cases were more or less likely to plead guilty than alcohol cases.

When asked whether the per se law may have resulted in increased OUID cases, some prosecutors said more cases were being brought but attributed part of that to increased drug use and officer training. Others, however, felt the volume remained fairly stable. Responses were again mixed in their perception of whether the per se law has made it easier to obtain convictions, though in general, they reported conviction rates for OUID have increased over time. They also reported the vast majority of OUID cases pled guilty and did not result in trials. They reported the law had not changed the way they prosecuted cases demonstrably, but then also said there was a reduced need to prove impairment. However, for some judges, establishment of impairment is necessary to develop probable cause to request the test. The prosecutors were generally supportive of the DRE program and felt most police officers are aware of the DUID law.

\section{Data}

Data for DRE evaluations in Wisconsin were obtained from the National DRE Database. OUIalcohol conviction data were obtained from the Wisconsin Department of Transportation's 2003 Alcohol Traffic Facts book. Data estimating OUID arrests are based on reports from the Wisconsin State Laboratory of Hygiene, which performs the vast majority of OUID drug sample analyses, and are based on samples submitted to it for analysis. Wisconsin's DRE coordinator 
said there were 99 active, certified DRE officers in the State in 2004. The IACP reported there were 113 DREs in Wisconsin at the end of 2007.

Table 15. Wisconsin's Summary Data on OUID and OUI Actions

\begin{tabular}{|c|c|c|c|c|c|c|}
\hline Year & $\begin{array}{c}\text { DRE } \\
\text { Evaluations } \\
\end{array}$ & $\begin{array}{c}\text { OUID } \\
\text { Arrests }\end{array}$ & $\begin{array}{c}\text { OUID } \\
\text { Convictions* }\end{array}$ & $\begin{array}{c}\text { OWI } \\
\text { Convictions } \\
\end{array}$ & $\begin{array}{l}\text { OWl } I^{* * *} \\
\text { Arrests } \\
\end{array}$ & $\begin{array}{c}\text { OWI }{ }^{* * *} \\
\text { Convictions }\end{array}$ \\
\hline 2005 & 372 & 2,350 & & & & \\
\hline 2004 & 327 & 1,868 & & & & \\
\hline $2003^{* *}$ & 234 & 1,452 & & & 39,037 & 31,055 \\
\hline 2002 & 188 & 1,309 & & 35,160 & 37,775 & 33,983 \\
\hline 2001 & 60 & 1,144 & & 34,686 & 38,731 & 33,164 \\
\hline
\end{tabular}

Wisconsin reported approximately 40,000 OWI arrests per year, leading up to implementation of the drug per se law. Drug-related arrests as measured by number of drug analyses requested amounted to approximately $3.4 \%$ of all impaired-driving arrests. Since the drug per se law was implemented, drug per se arrests account for approximately $5.2 \%$ of arrests. Though the percentage change is not dramatic, the absolute number of drug tests requested rose in the first two years after the law was implemented from 1,452 in the year the law went into effect to 1,868 in 2004 and 2,350 in 2005. So it appears implementation of the law has resulted in a growing number of drug-related violations of the impaired-driving statute in Wisconsin. 


\section{Descriptions of Other Drug Per Se States}

The information presented in this section is based on a review of the laws, extensive Internet, email, and telephone inquiries with potential key informants in the States, but did not involve site visits to the States. 


\section{Delaware}

\section{State with Drug Per Se Law and Active DRE Program}

\section{Summary of Delaware's Drug Per Se Law}

The provisions of Delaware law apply only to illicit or recreational drugs defined as the class of drugs that are per se illegal (e.g., cocaine or heroin) or certain controlled substances designated in the State or Federal uniform controlled substances acts (21 Delaware Code 4177) and are known to be regularly abused. Designer drugs and inhalants as defined under Delaware law are also included in this act.

A first offender can receive 60 days to 6 months imprisonment and fines ranging from $\$ 230$ to $\$ 1,150$. The offender's license will also be revoked for 12 months.

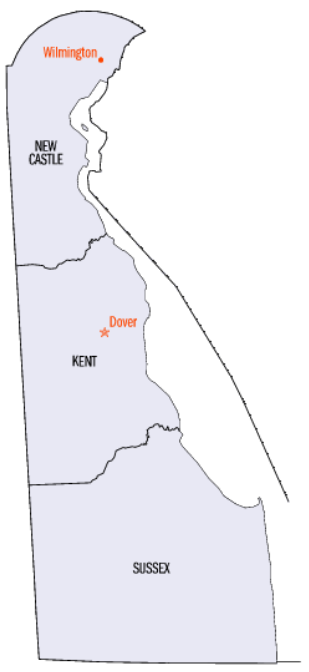

Figure 13. Delaware

\section{Effective Date}

Delaware's drug per se law took effect on July 10, 2007.

\section{Drug Per Se Law}

(a) No person shall drive a vehicle:

(1) When the person is under the influence of alcohol;

(2) When the person is under the influence of any drug;

(3) When the person is under the influence of a combination of alcohol and any drug;

(4) When the person's alcohol concentration is .08 or more; or

(5) When the person's blood contains, within 4 hours of driving, any amount of an illicit or recreational drug that is the result of the unlawful use or consumption of such illicit or recreational drug or any amount of a substance or compound that is the result of the unlawful use or consumption of an illicit or recreational drug prior to or during driving.

(6) When the person's blood contains, within 4 hours of driving, any amount of an illicit or recreational drug that is the result of the unlawful use or consumption of such illicit or recreational drug or any amount of a substance or compound that is the result of the unlawful use or consumption of an illicit or recreational drug prior to or during driving.

(b) In a prosecution for a violation of subsection (a) of this section:

(1) Except as provided in subparagraph (3)b. of this subsection, the fact that any person charged with violating this section is, or has been, legally entitled to use alcohol or a drug shall not constitute a defense.

(3)a. No person shall be guilty under subsection (a)(6) of this section when the person has not used or consumed an illicit or recreational drug prior to or during driving but has only used or consumed such drug after the person has ceased driving and only such use or consumption after driving caused the person's blood to contain an amount of the drug or an amount of a substance 
or compound that is the result of the use or consumption of the drug within 4 hours after the time of driving.

b. No person shall be guilty under subsection (a)(6) of this section when the person has used or consumed the drug or drugs detected according to the directions and terms of a lawfully obtained prescription for such drug or drugs.

\section{Statutory Sanctions}

Table 16. Delaware Statutory Sanctions

\begin{tabular}{|c|c|c|c|c|c|}
\hline State & $\begin{array}{c}\text { Drug Per } \\
\text { Se Law }\end{array}$ & $\begin{array}{c}\text { DRE } \\
\text { Program }\end{array}$ & Effective Date & Law & Sanctions for First Offense \\
\hline $\mathrm{DE}$ & Yes & Yes & July 10, 2007 & $\begin{array}{l}\text { The provisions of } \\
\text { Delaware law apply } \\
\text { only to illicit or } \\
\text { recreational drugs } \\
\text { defined as the class } \\
\text { of drugs that are per } \\
\text { se illegal (e.g., } \\
\text { cocaine or heroin) or } \\
\text { certain controlled } \\
\text { substances } \\
\text { designated in the } \\
\text { State or Federal } \\
\text { uniform controlled } \\
\text { substances acts ( } 21 \\
\text { Delaware Code } \\
4177) \text {. }\end{array}$ & $\begin{array}{l}\text { Criminal: Not more than } 60 \text { days (no } \\
\text { mandatory) imprisonment nor more } \\
\text { than } 6 \text { months, not more than } \$ 230 \text { or } \\
\text { more than } \$ 1,150 \text { fine for } 1 \text { st offense. } \\
\text { Court-Ordered Other: The court may } \\
\text { order the defendant to pay } \\
\text { compensation to a victim; the Court } \\
\text { may order defendant to and complete } \\
\text { a program of education or } \\
\text { rehabilitation. } \\
\text { Administrative: For a first offense, } \\
\text { licenses revoked for } 12 \text { months. }\end{array}$ \\
\hline
\end{tabular}

Criminal: Not more than 60 days (no mandatory) imprisonment nor more than 6 months, not more than $\$ 230$ or more than $\$ 1,150$ fine for first offense; not less than 60 days nor more than 18 months with 5 days (mandatory) imprisonment, not less than $\$ 575$ nor more than $\$ 2,300$ for second offense within 5 years; 1 year to 2 years imprisonment and $\$ 1,000$ to $\$ 3,000$ fine for third offense with 3 months mandatory; 2 to 5 years imprisonment with 6 months mandatory and $\$ 2,000$ to $\$ 6,000$ in fines for fourth or subsequent offense.

Court-Ordered Other: The court may order the defendant to pay compensation to a victim; the Court may order defendant to and complete a program of education or rehabilitation.

Administrative: For a first offense, licenses revoked for 12 months; for a second offense, revocation is 24 months; for a third offense, revocation is for 24 months; for a fourth or further subsequent offenses, revocation is for 60 months. 


\section{Implementation and Handling of Delaware's DUID Cases}

Probable cause must be developed by improper driving or equipment violation in order to make the initial stop. If, in contact with the driver, reasonable suspicion of alcohol or drug impairment is developed, further investigation is pursued.

\section{If, through SFST}

examination and observation, the driver shows physical impairment and a low BAC, or there are obvious signs of drug use (drug paraphernalia, etc.) apparent, the driver is arrested and further information is gathered.

A DRE may be called in to do an evaluation or the arresting officer may gather additional information on his or her own.

Typically, blood or urine samples are taken and sent to the State lab (for blood) or a private lab (for urine) for analysis. If a DRE is called the sample is likely to be urine and those test results are usually available within weeks. If a non-DRE officer conducts the full investigation, a blood sample is more likely to be requested and the analysis time is often on the order of six months.

If drug results are positive, the officer may send them to the licensing agency, which

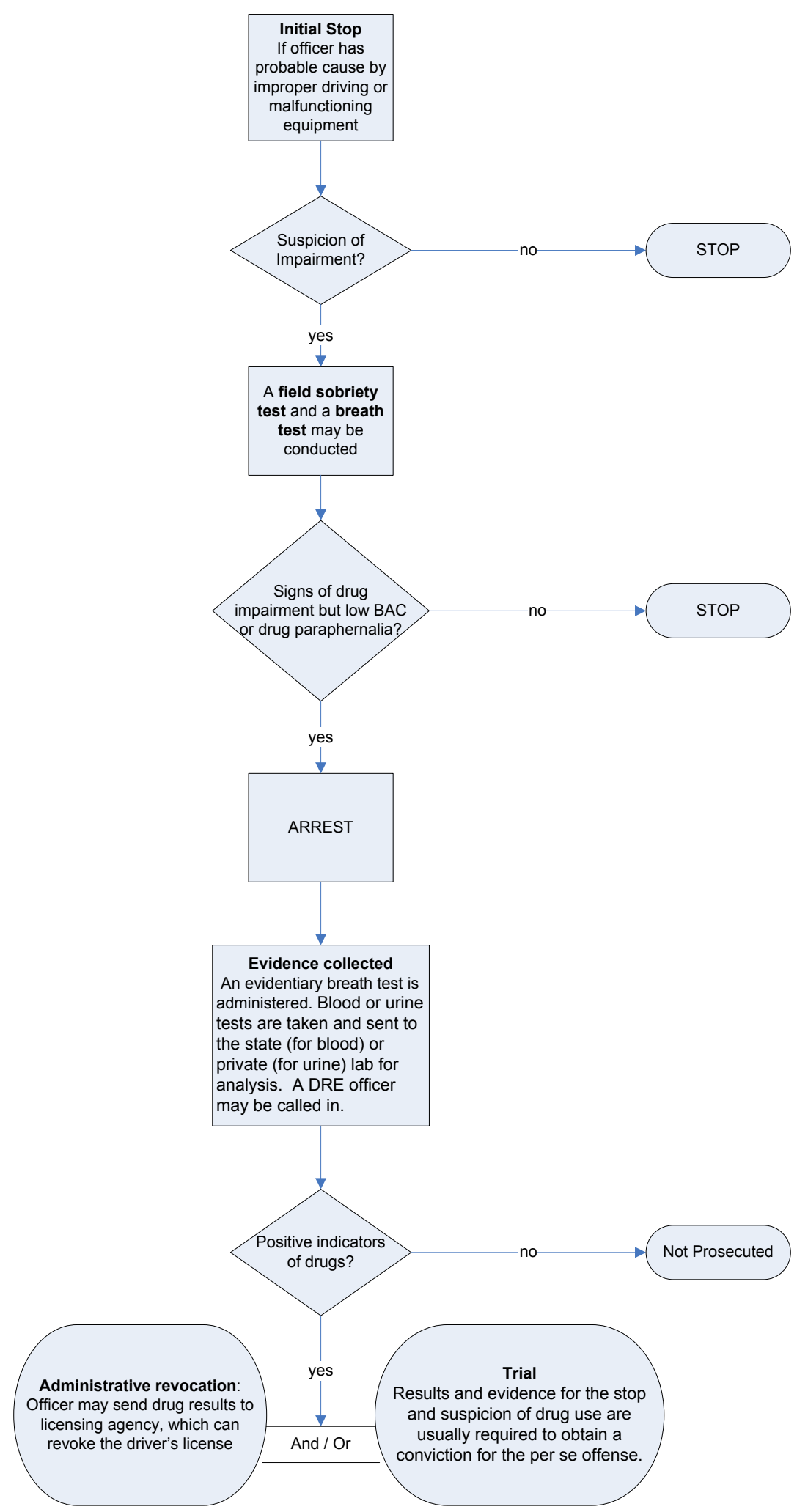

Figure 14. Delaware Flowchart 
can then administratively revoke the driver's license.

At trial, the presence of the drug and evidence for the stop and suspicion of drug use are usually required to obtain a conviction.

Delaware's official records do not readily distinguish between the DUID and DUI-alcohol arrest and disposition.

\section{Data}

Data for DRE Evaluations for the State of Delaware were obtained from the National DRE Database, maintained by PIRE under a separate project with NTHSA (DTNH22-02-D-95121Task order \#2). DUI-Alcohol (DUI-A) arrest data were obtained from the Delaware State DRE coordinator, who reported there were 8 certified DRE officers in the State as of 2004. The IACP confirmed this number for the end of 2007.

Table 17. Delaware's Summary Data on DUID and DUI-A Actions

\begin{tabular}{|c|c|c|c|c|c|}
\hline Year & $\begin{array}{c}\text { DRE } \\
\text { Evaluations }\end{array}$ & $\begin{array}{c}\text { DUID } \\
\text { Arrests* }^{*}\end{array}$ & $\begin{array}{c}\text { DUID } \\
\text { Convictions* }\end{array}$ & $\begin{array}{l}\text { DUID Lesser } \\
\text { Offense } \\
\text { Convictions* }\end{array}$ & $\begin{array}{c}\text { DUI-A } \\
\text { Arrests }\end{array}$ \\
\hline 2005 & 6 & & & & 6,061 \\
\hline 2004 & & & & & 5,981 \\
\hline 2003 & & & & & 5,964 \\
\hline 2002 & & & & & 5,840 \\
\hline
\end{tabular}

Because Delaware's law has only recently been implemented, information about the potential effects of the law is not yet available. 


\section{Georgia}

\section{State with Drug Per Se Law and Active DRE}

Program

\section{Summary of Georgia's Drug Per Se Law}

Georgia has a zero tolerance per se drugged driving law for marijuana, or any other controlled substances (Georgia Code Section 40-6-391).

Georgia law calls for a 24-hour mandatory imprisonment and a sentence of up to 12 months imprisonment, and up to $12-$ month suspension of license (no mandatory minimum) for a first offense.

\section{Effective Date}

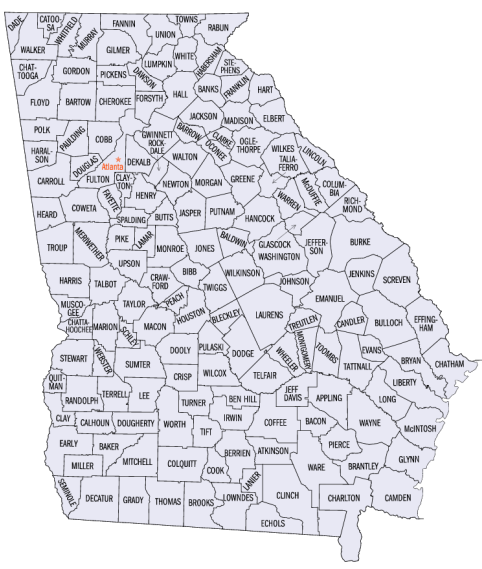

Figure 15. Georgia

Georgia's drug per se law took effect on July 1, 2001.

\section{Drug Per Se Law}

\section{Georgia Code $§ 40-6-391$}

(a) A person shall not drive or be in actual physical control of any moving vehicle while:

(1) Under the influence of alcohol to the extent that it is less safe for the person to drive;

(2) Under the influence of any drug to the extent that it is less safe for the person to drive;

(3) Under the intentional influence of any glue, aerosol, or other toxic vapor to the extent that it is less safe for the person to drive;

(4) Under the combined influence of any two or more of the substances specified in paragraphs (1) through (3) of this subsection to the extent that it is less safe for the person to drive;

(5) The person's alcohol concentration is 0.08 grams or more at any time within three hours after such driving or being in actual physical control from alcohol consumed before such driving or being in actual physical control ended; or

(6) Subject to the provisions of subsection (b) of this Code section, there is any amount of marijuana or a controlled substance, as defined in Code Section 16-1321 , present in the person's blood or urine, or both, including the metabolites and derivatives of each or both without regard to whether or not any alcohol is present in the person's breath or blood.

(b) The fact that any person charged with violating this Code section is or has been legally entitled to use a drug shall not constitute a defense against any charge of violating this Code section; provided, however, that such person shall not be in violation of this Code section unless such person is rendered incapable of driving safely as a result of using a drug other than alcohol which such person is legally entitled to use. 


\section{Drug Specifics}

The per se portion of the law applies to marijuana and its metabolites as well as controlled substance, which means a drug, substance, or immediate precursor in Schedules I through V of Code Sections 16-13-25 through 16-13-29 and Schedules I through V of 21 C.F.R. Part 1308. More detailed information on specific drugs appears in Appendix B.

\section{Statutory Sanctions}

Table 18. Georgia Statutory Sanctions

\begin{tabular}{|c|c|c|c|c|c|}
\hline State & $\begin{array}{c}\text { Drug Per } \\
\text { Se Law }\end{array}$ & $\begin{array}{c}\text { DRE } \\
\text { Program }\end{array}$ & Effective Date & Law & Sanctions for First Offense \\
\hline \multirow{3}{*}{ GA } & \multirow{3}{*}{ Yes } & \multirow{3}{*}{ Yes } & \multirow{3}{*}{ July 1, 2001} & \multirow{3}{*}{$\begin{array}{l}\text { Georgia has a } \\
\text { zero-tolerance per } \\
\text { se drugged driving } \\
\text { law for marijuana, } \\
\text { or any other } \\
\text { controlled } \\
\text { substances } \\
\text { (Georgia Code } \\
\text { Section 40-6-391). }\end{array}$} & $\begin{array}{l}\text { Criminal: } 10 \text { days ( } 24 \text { hours } \\
\text { mandatory) to } 12 \text { months } \\
\text { imprisonment, } \$ 300 \text { (mandatory) to } \\
\$ 1,000 \text { fine for } 1 \text { st offense; } 7 \text { to } 15 \\
\text { years for DUI with a severe injury } \\
\text { (felony conviction). }\end{array}$ \\
\hline & & & & & $\begin{array}{l}\text { Court-Ordered Other: The court must } \\
\text { order community service as follows: } \\
\text { not less than } 40 \text { hours ( } 40 \\
\text { mandatory) for } 1 \text { st offense. } \\
\text { Restitution may be ordered. Various } \\
\text { fees and assessments must be } \\
\text { assessed. The name, address and } \\
\text { photo of } 2 \text { nd and subsequent } \\
\text { offenders shall be published in the } \\
\text { appropriate county. Probation is } \\
\text { mandatory if the jail sentence is less } \\
\text { than } 1 \text { year. }\end{array}$ \\
\hline & & & & & $\begin{array}{l}\text { Administrative: } 12 \text { months (no } \\
\text { mandatory minimum) suspension for } \\
\text { 1st offense; } 3 \text { years (mandatory) } \\
\text { suspension of a DUI with a serious } \\
\text { injury. Forfeiture is mandatory for } \\
\text { habitual offenders. }\end{array}$ \\
\hline
\end{tabular}

Criminal: 10 days (24 hours mandatory) to 12 months imprisonment, $\$ 300$ (mandatory) to $\$ 1,000$ fine for first offense; 90 days (48 hours mandatory) to 12 months, $\$ 600$ (mandatory) to $\$ 1,000$ for second offense within 5 years; 120 days (10 days mandatory) to 12 months, $\$ 1,000$ (mandatory or $\$ 500$ plus a drug treatment program) to $\$ 5,000$ for third or subsequent offense within 5 years; 7 to 15 years for DUI with a severe injury (felony conviction).

Court-Ordered Other: The court must order community service as follows: not less than 40 hours (40 mandatory) for first offense; not less than 80 hours mandatory) for second offense within 5 years; not less than 20 days ( 20 days mandatory) for third or subsequent offense within 5 years. Restitution may be ordered. Various fees and assessments must be assessed. The name, address and photo of second and subsequent offenders shall be published in the appropriate county. Probation is mandatory if the jail sentence is less than 1 year. 
Administrative: 12 months (no mandatory minimum) suspension for first offense; 3 years (120 days mandatory) suspension for second offense; 5 years ( 2 years mandatory) revocation for third offense within 5 years; 3 years ( 2 years mandatory) revocation for third offense within 5 years; 3 years (mandatory) suspension of a DUI with a serious injury. Forfeiture is mandatory for habitual offenders (Walsh, Danziger, Cangianelli, \& Koehler, 2002). 


\section{Implementation and Handling of Georgia's DUID Cases}

An officer must develop

probable cause by

improper driving or

equipment violation in order to make the initial stop. If, in contact with the driver, reasonable suspicion of alcohol or drug impairment is developed, the officer investigates further.

If, through SFST

examination and observation, the driver shows physical impairment and a low BAC, or there are obvious signs of drug use (drug paraphernalia, etc.) apparent, the driver is arrested and the officer gathers further information.

A DRE may be called in to do an evaluation or the arresting officer may gather additional information on his or her own.

Typically, the officer requests blood or urine samples, which are taken and sent to the State or local agency lab for analysis. Blood is preferred.

If drug results are positive, the officer may send them to the licensing agency, which can then administratively revoke the driver's license.

At trial, the presence of the drug and evidence for the stop and suspicion of drug

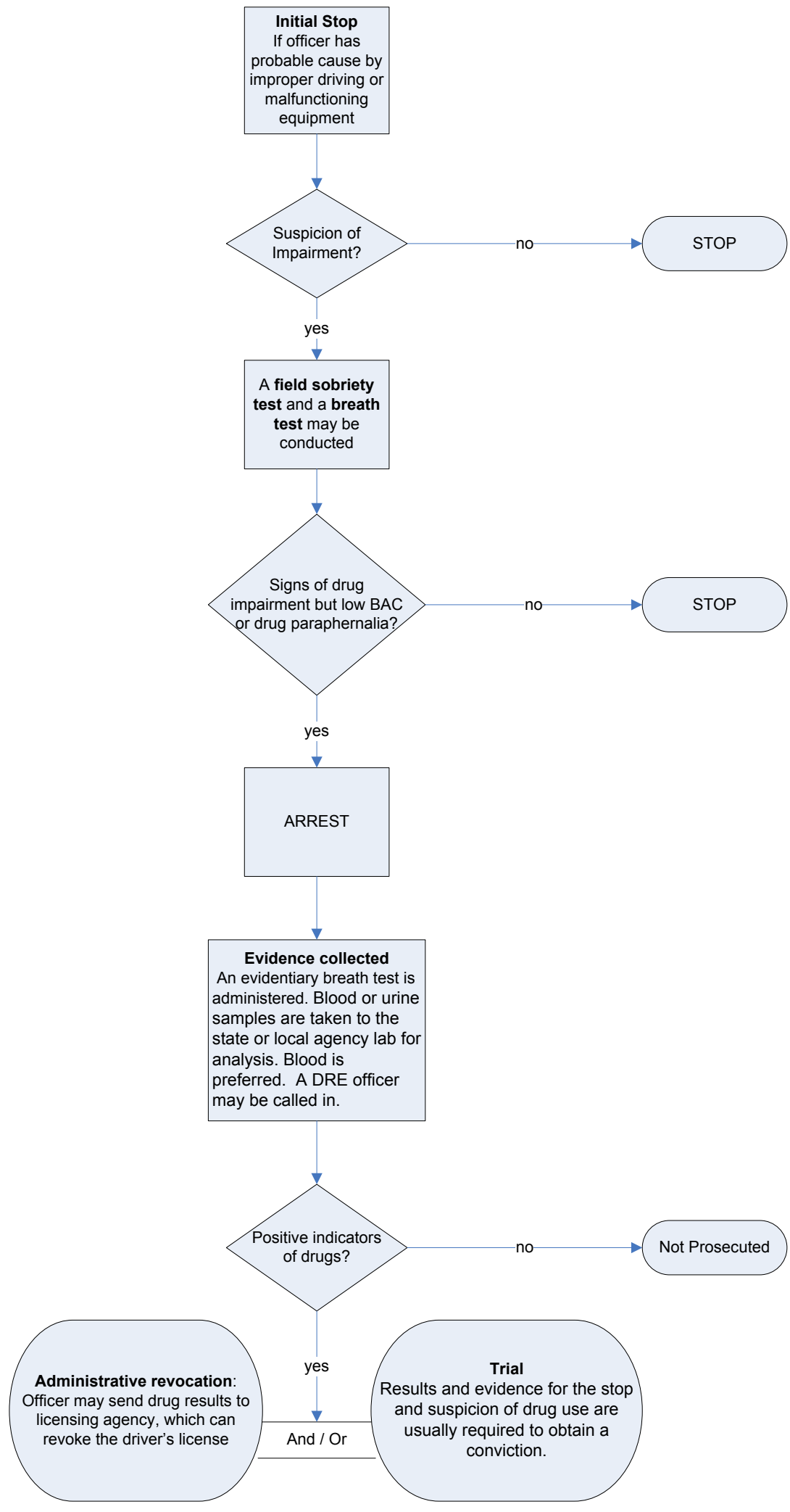

Figure 16. Georgia Flowchart 
use are usually required to obtain a conviction.

Georgia's official records do not readily distinguish between the DUID and DUI-alcohol arrest and disposition.

\section{Data}

Data for DRE evaluations for Georgia were obtained from the National DRE Database. The Georgia DRE coordinator reports in 2004 there were 105 active DRE officers. The IACP reported there were 47 DREs in Georgia at the end of 2007. DUID and DUI-Alcohol (DUI-A) data were provided by the Georgia Bureau of Investigation (Christine Stover, Georgia Bureau of Investigation, personal communication, 2008).

Table 19. Georgia's Summary Data on DUID and DUI-A Actions

\begin{tabular}{lcrlrr|r}
\hline & & & & & \\
Year & $\begin{array}{c}\text { DRE } \\
\text { Evaluations }\end{array}$ & $\begin{array}{c}\text { DUID } \\
\text { Arrests }\end{array}$ & $\begin{array}{c}\text { DUID } \\
\text { Convictions }\end{array}$ & $\begin{array}{c}\text { DUID Lesser } \\
\text { Offense } \\
\text { Convictions* }\end{array}$ & $\begin{array}{c}\text { DUI-A } \\
\text { Arrests }\end{array}$ & $\begin{array}{r}\text { DUI Alcohol } \\
\text { Convictions }\end{array}$ \\
\hline $\mathbf{2 0 0 5}$ & 152 & 3,118 & 1,027 & 49,103 & 28,618 \\
\hline $\mathbf{2 0 0 4}$ & 256 & 2,905 & 1,182 & 51,085 & 32,170 \\
\hline $\mathbf{2 0 0 3}$ & 125 & 2,996 & 1,194 & 52,287 & 34,587 \\
\hline $\mathbf{2 0 0 2}$ & 163 & 2,860 & 1,225 & 57,526 & 39,692 \\
\hline $\mathbf{2 0 0 1 * *}$ & 169 & 2,497 & 1,122 & 57,347 & 39,597 \\
\hline $\mathbf{2 0 0 0}$ & 74 & 2,385 & 893 & 55,791 & 37,708 \\
\hline $\mathbf{1 9 9 9}$ & 64 & 3,187 & 1,253 & 56,341 & 39,056 \\
\hline
\end{tabular}

* Data not available

** Per Se law went into effect

Examination of the DUID arrest information in Table 19 shows the volume of DUID arrests has increased in Georgia subsequent to the implementation of the law in 2001. In 2005, the fourth full year after implementation of the law there were 3,118 DUID arrests reported, a 25\% increase over 2001, the year of implementation of the law. 


\section{Illinois}

\section{State with Drug Per Se Law and DRE Activity}

\section{Summary of Illinois' Drug Per Se Law}

Illinois has a zero-tolerance per se drugged driving law enacted for intoxicating compounds, other drugs, cannabis, and controlled substances (Illinois Compiled Statutes 625 ILCS 5/11-501).

Illinois law calls for up to 12 months imprisonment (no mandatory), and a 3-month license suspension (no mandatory) for a first offense.

\section{Effective Date}

Illinois' drug per se law took effect on August 15, 1997.

\section{Drug Per Se Law}

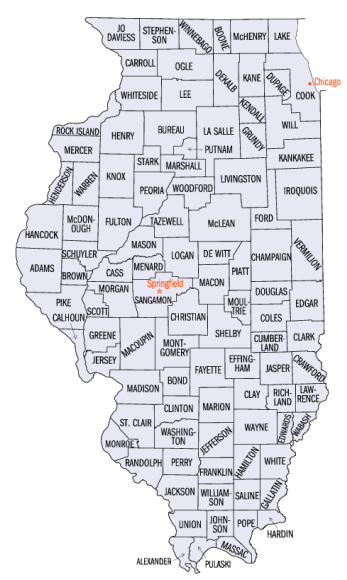

\section{ILCS 5/11-501}

(a) A person shall not drive or be in actual physical control of any vehicle within this State while:

(1) The alcohol concentration in the person's blood or breath is 0.08 or more based on the definition of blood and breath units in Section 11-501.2;

(2) Under the influence of alcohol;

(3) Under the influence of any intoxicating compound or combination of intoxicating compounds to a degree that renders the person incapable of driving safely;

(4) Under the influence of any other drug or combination of drugs to a degree that renders the person incapable of safely driving;

(5) Under the combined influence of alcohol, other drug or drugs, or intoxicating compound or compounds to a degree that renders the person incapable of safely driving; or

(6) There is any amount of a drug, substance, or compound in the person's breath, blood, or urine resulting from the unlawful use or consumption of cannabis listed in the Cannabis Control Act, a controlled substance listed in the Illinois Controlled Substances Act, or an intoxicating compound listed in the Use of Intoxicating Compounds Act.

(b) The fact that any person charged with violating this Section is or has been legally entitled to use alcohol, other drug or drugs, or intoxicating compound or compounds, or any combination thereof, shall not constitute a defense against any charge of violating this Section.

\section{Drug Specifics}

Drugs covered are intoxicating compounds, cannabis, controlled substances, and other drugs. 


\section{Statutory Sanctions}

\section{Table 20. Illinois Statutory Sanctions}

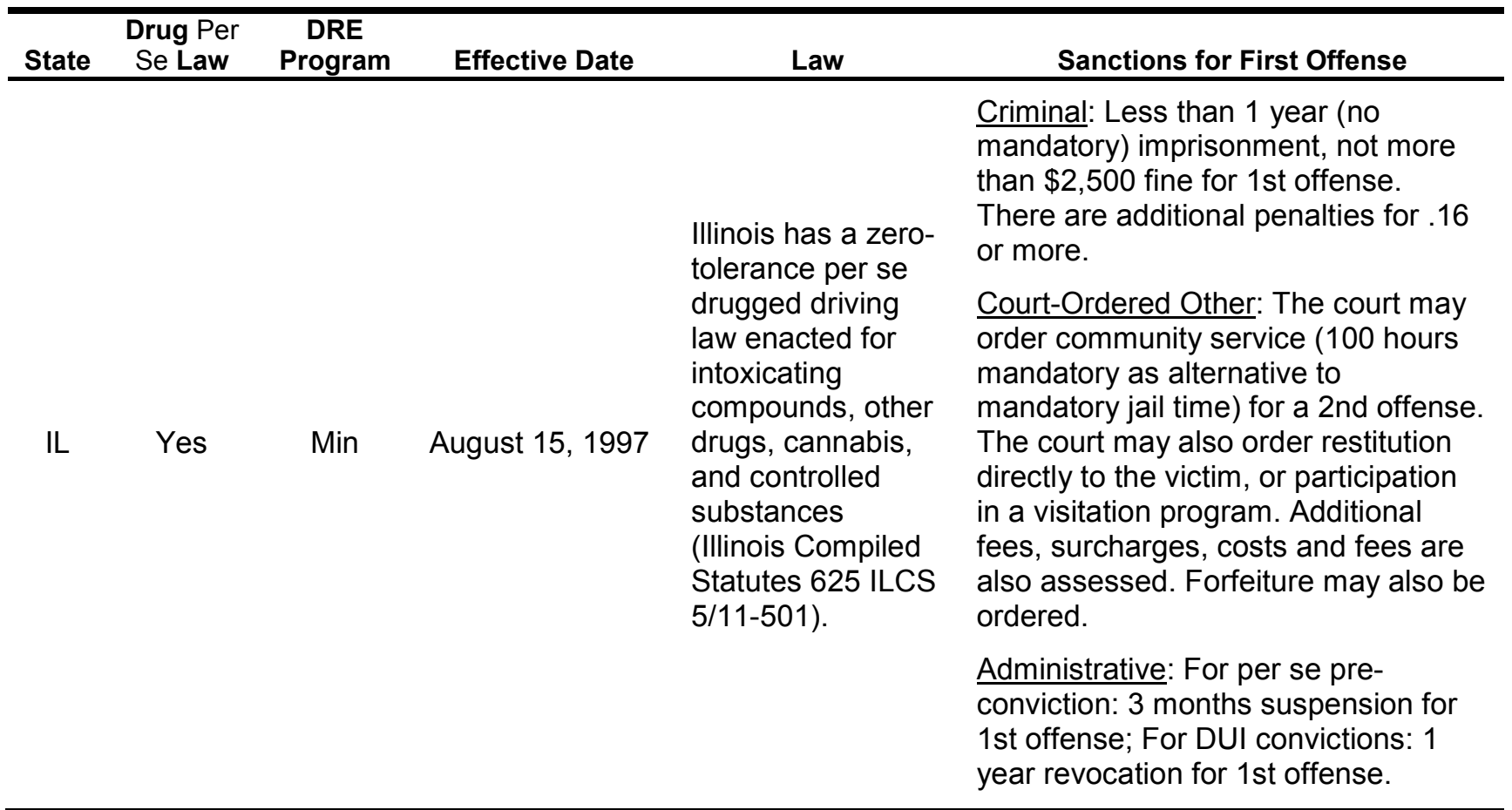

Criminal: Less than 1 year (no mandatory) imprisonment, not more than $\$ 2,500$ fine for first offense; less than 1 year (48 hours mandatory), not more than $\$ 2,500$ for second offense; 1 year (48 hours mandatory) to 3 years, not more than $\$ 25,000$ for third or subsequent offenses is a felony.

Second offense should be 5 days.

Third offense should be 10 days.

There are additional penalties for .16 or more.

Note: After third offense it is a felony regardless of how much time has lapsed.

Court-Ordered Other: The court may order community service (100 hours mandatory as alternative to mandatory jail time) for a second offense; 30 days mandatory in lieu of mandatory jail time) for third or subsequent offense. The court may also order restitution directly to the victim, or participation in a visitation program. Additional fees, surcharges, costs and fees are also assessed. Forfeiture may also be ordered.

Administrative: For per se pre conviction: 3 months suspension for first offense; 1 year (90 days mandatory) suspension for subsequent offense within 5 years. For DUI convictions: 1 year revocation for first offense; 5 years revocation for second offense within 20 years; 10 years revocation for third offense; permanent revocation for subsequent offenses. 


\section{Implementation and Handling of IIlinois' DUID Cases}

An officer must develop probable cause by improper driving or equipment violation in order to make the initial stop. Other circumstances, such as observations at a roadside safety check or the result of a traffic crash investigation, may also be used to help develop probable cause. If, in contact with the driver, the officer has reasonable suspicion of alcohol or drug impairment, he or she investigates the situation further.

If the driver shows physical impairment and a low BAC, or there are obvious signs of drug use (drug paraphernalia, etc.) apparent, the driver is arrested and further information is gathered.

Typically, the arresting officer gathers additional information to support the charge.

Typically, a urine sample is obtained and sent to the State or local agency lab for drug analysis. Blood is sometimes used for alcohol analyses.

If drug results are positive, the officer may send them to the licensing agency, which can then administratively revoke the driver's license.

At trial, the presence of the drug and evidence for the stop and suspicion of drug

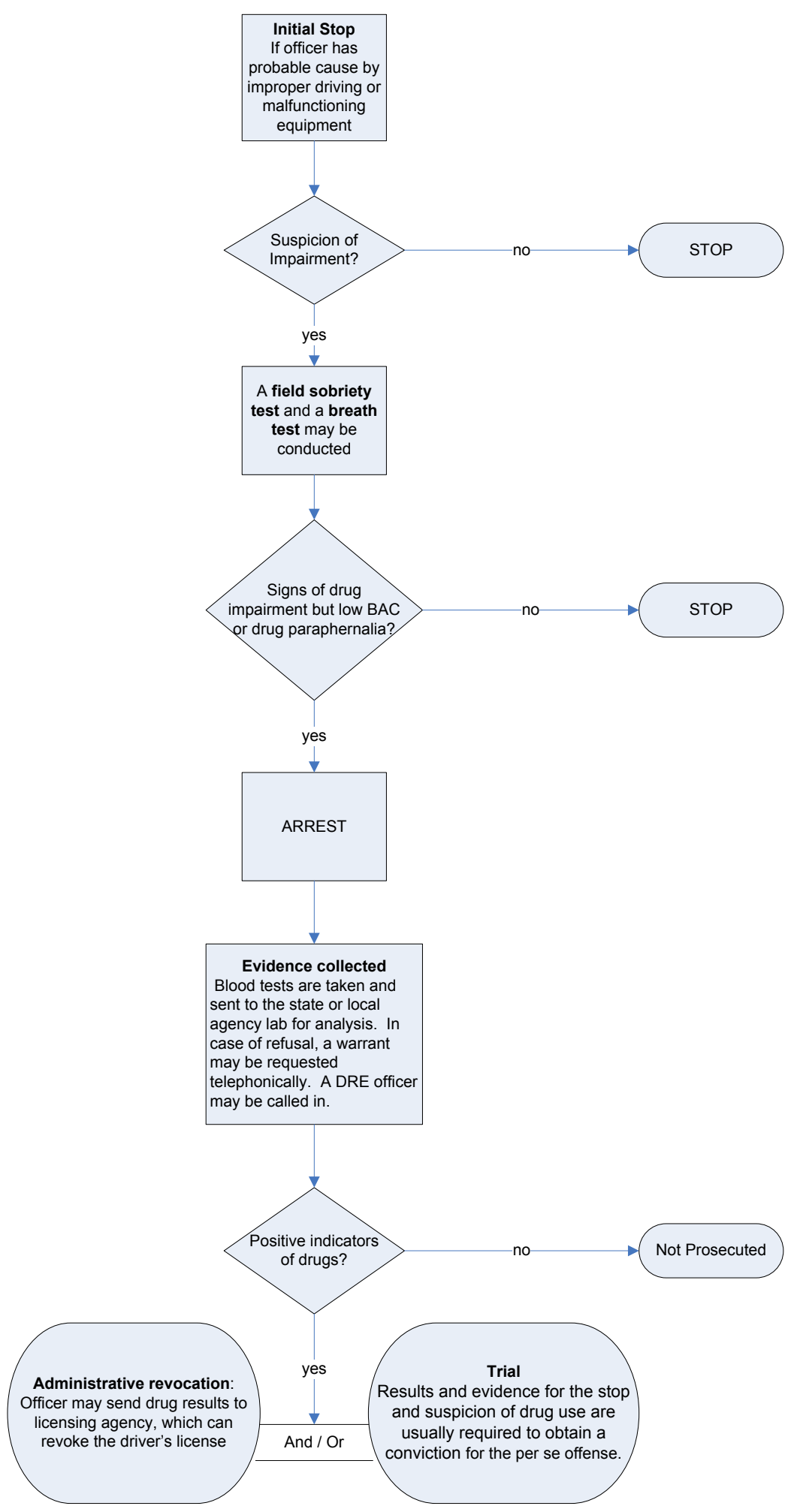

Figure 18. Illinois Flowchart 
use are usually required to obtain a conviction.

Illinois official records do not readily distinguish between the DUID and DUI-alcohol arrest and disposition

\section{Data}

DUI-Alcohol (DUI-A) arrest data for Illinois were obtained from the Illinois Secretary of State's "DUI Fact Book" (2008). The Illinois DRE coordinator reports he is the only certified DRE in the State. The IACP also reported there was one DRE in Illinois at the end of 2007.

Table 21. Illinois' Summary Data on DUID and DUI-A Actions

\begin{tabular}{|c|c|c|c|c|c|}
\hline Year & $\begin{array}{c}\text { DRE } \\
\text { Evaluations* }\end{array}$ & $\begin{array}{c}\text { DUID } \\
\text { Arrests* }\end{array}$ & $\begin{array}{c}\text { DUID } \\
\text { Convictions* }\end{array}$ & $\begin{array}{c}\text { DUID Lesser } \\
\text { Offense } \\
\text { Convictions* }\end{array}$ & $\begin{array}{c}\text { DUI-A } \\
\text { Arrests }\end{array}$ \\
\hline \multicolumn{6}{|l|}{2005} \\
\hline 2004 & & & & & 50,147 \\
\hline 2003 & & & & & 49,569 \\
\hline 2002 & & & & & 51,649 \\
\hline 2001 & & & & & 49,676 \\
\hline 2000 & & & & & 51,358 \\
\hline 1999 & & & & & 48,587 \\
\hline 1998 & & & & & 49,547 \\
\hline $1997^{* *}$ & & & & & 47,034 \\
\hline 1996 & & & & & 44,433 \\
\hline 1995 & & & & & \\
\hline
\end{tabular}




\section{Indiana}

\section{State with Drug Per Se Law and Active DRE Program}

\section{Summary of Indiana's Drug Per Se Law}

Indiana has a zero-tolerance per se drugged driving law enacted for controlled substances listed in schedules I and II of Section 35-48-2, and their metabolites (Indiana Statutes Section 9-30-51). Prescription use is an affirmative defense.

Indiana law calls for up to 60 days imprisonment, and up to 2year license suspension (30-day mandatory) for first per se offense.

\section{Effective Date}

Indiana's drug per se law took effect on July 1, 2001.

\section{Drug Per Se Law}

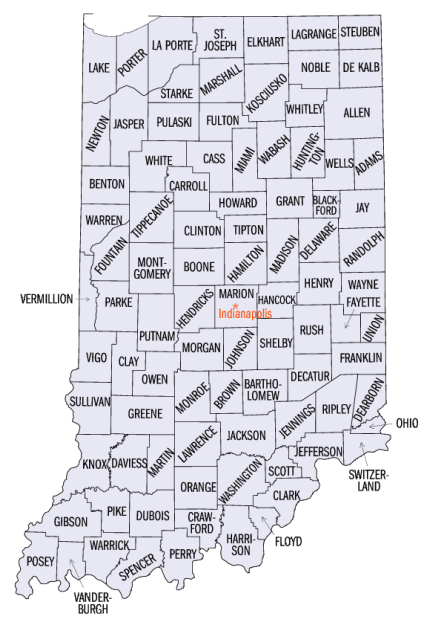

Ind. Code Ann. $\$$ 9-30-5-1

Figure 19. Indiana

(a) A person who operates a vehicle with an alcohol concentration equivalent to at least eight-hundredths (0.08) gram of alcohol but less than fifteen-hundredths $(0.15)$ gram of alcohol per:

(1) one hundred (100) milliliters of the person's blood; or

(2) two hundred ten (210) liters of the person's breath; commits a Class C misdemeanor.

(b) A person who operates a vehicle with an alcohol concentration equivalent to at least fifteen-hundredths (0.15) gram of alcohol per:

(1) one hundred (100) milliliters of the person's blood; or

(2) two hundred ten (210) liters of the person's breath; commits a Class A misdemeanor.

(c) A person who operates a vehicle with a controlled substance listed in schedule I or II of IC 35-48-2 or its metabolite in the person's body commits a Class $\mathrm{C}$ misdemeanor.

(d) It is a defense to subsection (c) that the accused person consumed the controlled substance under a valid prescription or order of a practitioner (as defined in IC 35-48-1) who acted in the course of the practitioner's professional practice.

\section{Drug Specifics}

Drugs covered include controlled substances listed in schedules I and II of Section 35-48-2, and drugs other than alcohol or controlled substances (see Appendix B for more details). 


\section{Statutory Sanctions}

Table 22. Indiana Statutory Sanctions

\begin{tabular}{|c|c|c|c|c|c|}
\hline State & $\begin{array}{c}\text { Drug Per } \\
\text { Se Law }\end{array}$ & $\begin{array}{c}\text { DRE } \\
\text { Program } \\
\end{array}$ & Effective Date & Law & Sanctions for First Offense \\
\hline \multirow{3}{*}{ IN } & \multirow{3}{*}{ Yes } & \multirow{3}{*}{ Yes } & \multirow{3}{*}{ July 1, 2001} & \multirow{3}{*}{$\begin{array}{l}\text { Indiana has a } \\
\text { zero-tolerance per } \\
\text { se drugged driving } \\
\text { law enacted for } \\
\text { controlled } \\
\text { substances listed } \\
\text { in schedules I and } \\
\text { II of Section } 35- \\
48-2 \text {, and their } \\
\text { metabolites } \\
\text { (Indiana Statutes } \\
\text { Section 9-30-5-1). } \\
\text { Prescription use is } \\
\text { an affirmative } \\
\text { defense. }\end{array}$} & $\begin{array}{l}\text { Criminal: Not more than } 60 \text { days } \\
\text { imprisonment, not more than } \$ 500 \\
\text { fine for } 1 \text { st per se offense; not more } \\
\text { than } 1 \text { year, not more than } \$ 500 \text { fine } \\
\text { for } 1 \text { st DUI offense. }\end{array}$ \\
\hline & & & & & $\begin{array}{l}\text { Court-Ordered Other: The court may } \\
\text { order community service, restitution of } \\
\text { not more than } \$ 1,000 \text { to the victim, } \\
\text { various fees and assessments, } \\
\text { participation in a victim impact } \\
\text { program, and home detention. }\end{array}$ \\
\hline & & & & & $\begin{array}{l}\text { Administrative: } 90 \text { days ( } 30 \text { days } \\
\text { mandatory) to } 2 \text { years suspension for } \\
\text { 1st offense. }\end{array}$ \\
\hline
\end{tabular}

Criminal: Not more than 60 days imprisonment, not more than $\$ 500$ fine for first per se offense; not more than 1 year, not more than $\$ 500$ fine for first DUI offense; not more than $1 \frac{1}{2}$ years (5 days mandatory), not more than $\$ 10,000$ for any second offense within 5 years (felony); not more than $1 \frac{1}{2}$ years (10 days mandatory), not more than $\$ 10,000$ for third offense within 5 years (felony); fixed term of 2 years, not more than $\$ 10,000$ for serious injury DUI offense (felony); fixed term of 4 years, not more than $\$ 10,000$ for subsequent serious injury DUI offense (felony).

Court-Ordered Other: The court may order community service, restitution of not more than $\$ 1,000$ to the victim, various fees and assessments, participation in a victim impact program, and home detention.

Administrative: 90 days (30 days mandatory) to 2 years suspension for first offense; 180 days (mandatory) to 2 years suspension for second or subsequent offense within 5 years; 2 years (mandatory) to 5 years suspension for an injury related per se or DUI offense. 


\section{Implementation and Handling of Indiana's OWID Cases}

An officer must develop probable cause by improper driving or equipment violation in order to make the initial stop. If, in contact with the driver, reasonable suspicion of alcohol or drug impairment is developed, further investigation is pursued.

If the driver shows physical impairment and a low BAC, or there are obvious signs of drug use (drug paraphernalia, etc.) apparent, the driver is arrested and further information is gathered.

A DRE may be called in to do an evaluation or the arresting officer may gather additional information.

Typically, blood samples are taken and sent to the State or local agency lab for analysis.

If drug results are positive, the officer may send them to the licensing agency, which can then administratively revoke the driver's license.

In case of refusal, the officer telephonically requests a warrant and takes a blood sample, usually administered at a hospital in metropolitan areas, but sometimes by an officer who has had phlebotomy training.

At trial, the presence of the drug and evidence for the stop and suspicion of drug use are usually required to obtain a conviction.

Indiana's official records do not readily distinguish between the

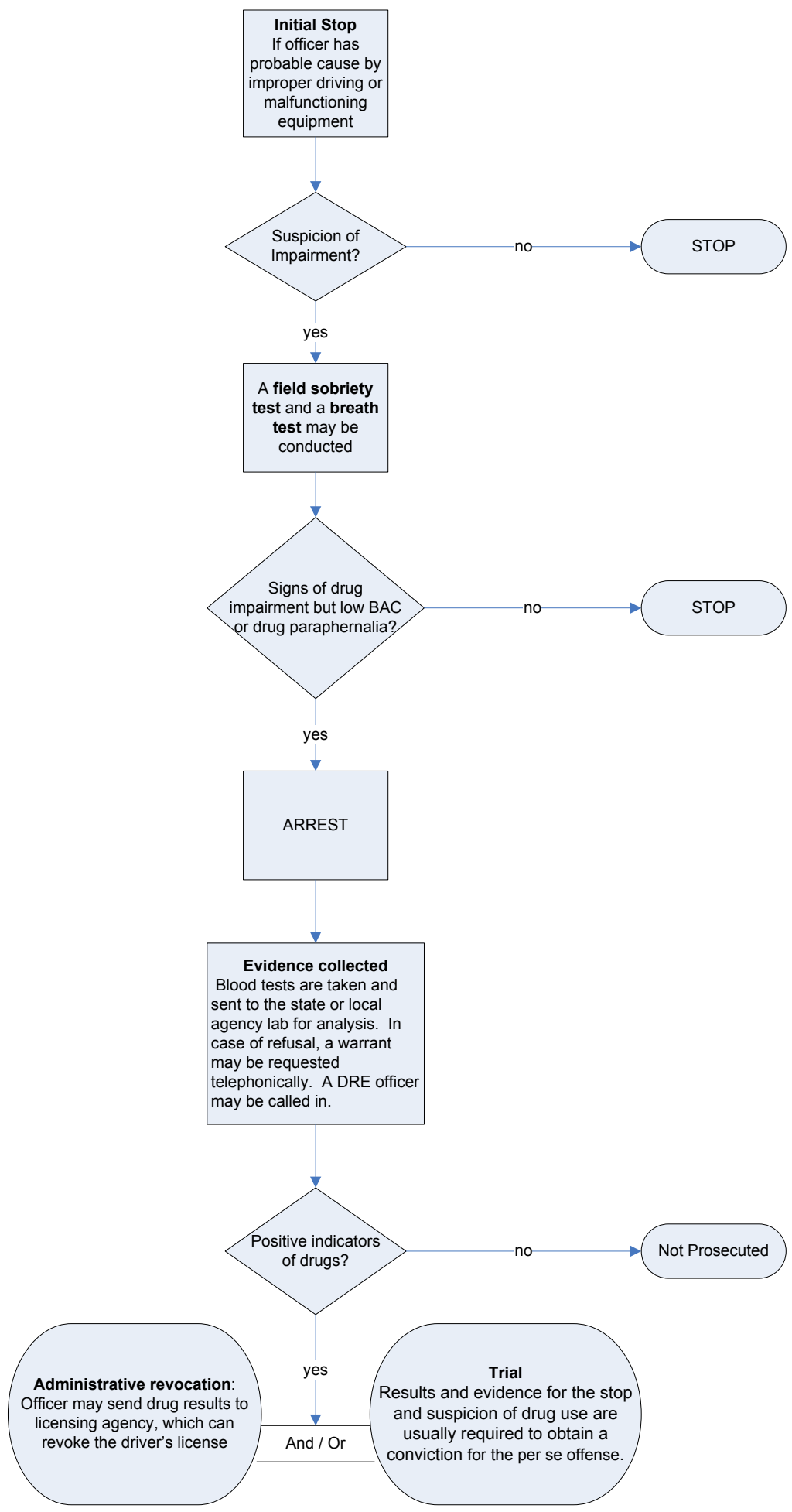

Figure 20. Indiana Flowchart 
DUID and DUI-alcohol arrest and disposition.

\section{Data}

Data for DRE evaluations for Indiana were obtained from the National DRE Database. Indiana reported having 154 active DRE officers in 2004. The IACP reported there were 125 DREs in Indiana at the end of 2007.

Table 23. Indiana's Summary Data on DUID and DUI Actions

\begin{tabular}{|c|c|c|c|c|c|}
\hline Year & $\begin{array}{c}\text { DRE } \\
\text { Evaluations } \\
\end{array}$ & $\begin{array}{c}\text { DUID } \\
\text { Arrests* }\end{array}$ & $\begin{array}{c}\text { DUID } \\
\text { Convictions* }\end{array}$ & $\begin{array}{l}\text { DUID Lesser } \\
\text { Offense } \\
\text { Convictions* }\end{array}$ & $\begin{array}{c}\text { DUI-A } \\
\text { Arrests* }\end{array}$ \\
\hline 2005 & 371 & & & & \\
\hline 2004 & 330 & & & & \\
\hline 2003 & 294 & & & & \\
\hline 2002 & 225 & & & & \\
\hline $2001^{*}$ & 59 & & & & \\
\hline 2000 & 50 & & & & \\
\hline 1999 & 17 & & & & \\
\hline
\end{tabular}

Though data on DUID arrests in Indiana are not available, there is a marked increase in the number of DRE evaluations were conducted in the years following implementation of the drug per se law. 


\section{Minnesota}

\section{State with Drug Per Se Law and Active DRE Program}

\section{Summary of Minnesota's Drug Per Se Law}

Minnesota has a zero tolerance per se drugged driving law enacted for Schedule I or II controlled substances or their metabolites (Minnesota Statutes 169A.20). Impairment needs to be established for other controlled substances and hazardous substances.

Minnesota law calls for up to 90 days imprisonment (48 hours mandatory), and 90 days (15 days no limited license) revocation for first offense.

\section{Effective Date}

Minnesota's drug per se law took effect on August 1, 2006.

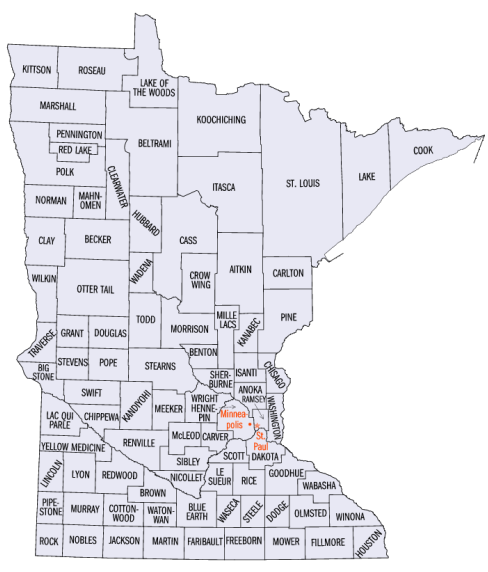

\section{Drug Per Se Law}

\section{Minn. Stat. § 169A.20. Driving while impaired.}

Subdivision 1 Driving while impaired crime. It is a crime for any person to drive, operate, or be in physical control of any motor vehicle within this State or on any boundary water of this State:

(1) When the person is under the influence of alcohol;

(2) When the person is under the influence of a controlled substance;

(3) When the person is knowingly under the influence of a hazardous substance that affects the nervous system, brain, or muscles of the person so as to substantially impair the person's ability to drive or operate the motor vehicle;

(4) When the person is under the influence of a combination of any two or more of the elements named in clauses (1), (2), and (3);

(5) When the person's alcohol concentration at the time, or as measured within two hours of the time, of driving, operating, or being in physical control of the motor vehicle is 0.08 or more;

(6) When the vehicle is a commercial motor vehicle and the person's alcohol concentration at the time, or as measured within two hours of the time, of driving, operating, or being in physical control of the commercial motor vehicle is 0.04 or more; or

(7) When the person's body contains any amount of a controlled substance listed in schedule I or II, or its metabolite, other than marijuana or tetrahydrocannabinols.

\section{Drug Specifics}

When the person's body contains any amount of a controlled substance listed in schedule I or II other than marijuana or tetrahydrocannabinols. 


\section{Statutory Sanctions}

Table 24. Minnesota Statutory Sanctions

\begin{tabular}{|c|c|c|c|c|c|}
\hline State & $\begin{array}{l}\text { Drug Per } \\
\text { Se Law }\end{array}$ & $\begin{array}{c}\text { DRE } \\
\text { Program }\end{array}$ & Effective Date & Law & Sanctions for First Offense \\
\hline MN & Yes & Yes & August 1, 2006 & $\begin{array}{l}\text { Minnesota has a } \\
\text { zero tolerance per } \\
\text { se drugged driving } \\
\text { law enacted for } \\
\text { Schedule I or II } \\
\text { controlled } \\
\text { substances or their } \\
\text { metabolites } \\
\text { (Minnesota Statutes } \\
\text { 169A.20). }\end{array}$ & $\begin{array}{l}\text { Criminal: Up to } 90 \text { days ( } 48 \text { hours } \\
\text { mandatory) imprisonment, not more } \\
\text { than } \$ 1,000 \text { fine for misdemeanor } \\
\text { (first offense within ten years driving } \\
\text { under the influence of a controlled } \\
\text { substance). } \\
\text { Court-Ordered Other: The court may } \\
\text { order community service in lieu of } \\
\text { jail time, restitution to the victim } \\
\text { directly or to the Victim's Fund, } \\
\text { assessments and surcharges, and } \\
\text { participation in a chemical use } \\
\text { dependency treatment program. } \\
\text { Administrative: } 90 \text { days (15 days no } \\
\text { limited license) revocation for } 1 \text { st } \\
\text { offense. }\end{array}$ \\
\hline
\end{tabular}

Criminal: Up to 90 days (48 hours mandatory) imprisonment, not more than $\$ 1,000$ fine for misdemeanor (first offense within ten years driving under the influence of a controlled substance); not more than 1 year (30 days mandatory), not more than $\$ 3,000$ fine for second or third offense within 10 years for gross misdemeanors (driving under the influence of a controlled substance). Fourth offense within 10 years is a felony with a penalty of up to 7 years in prison with a 5-year conditional release to follow and a $\$ 14,000$ fine. Subsequent offenses are also felonies.

Court-Ordered Other: The court may order community service in lieu of jail time, restitution to the victim directly or to the Victim's Fund, assessments and surcharges, and participation in a chemical use dependency treatment program.

Administrative: First Offense, 90 days (15 days no limited license) revocation for first offense, 180 days ( 90 days no limited license) revocation for second or subsequent offense within 10 years and minimum 1 year license revocation for a third offense. 


\section{Implementation and Handling of Minnesota's DWID Cases}

An officer must have articulable suspicion developed by observing improper driving or an equipment violation in order to make the initial stop. If, in contact with the driver, reasonable suspicion of alcohol or drug impairment is developed, further investigation is pursued.

If the driver shows physical impairment and a low BAC, or there are obvious signs of drug use (drug paraphernalia, etc.) apparent, the driver is arrested and the officer gathers further information.

A DRE may be called in to do an evaluation or the arresting officer may gather additional information.

Typically, the officer requests a blood or urine sample from the driver and sends it to the State or local agency lab for analysis.

If drug results are positive for Schedule I or II controlled substances, the officer may send them to the licensing agency, which can then administratively revoke the driver's license.

At trial, the presence of the drug and evidence for the stop and suspicion of drug use are usually required to obtain a conviction.

Minnesota's official records do not readily distinguish between the DWID and DWI-alcohol arrest and disposition.

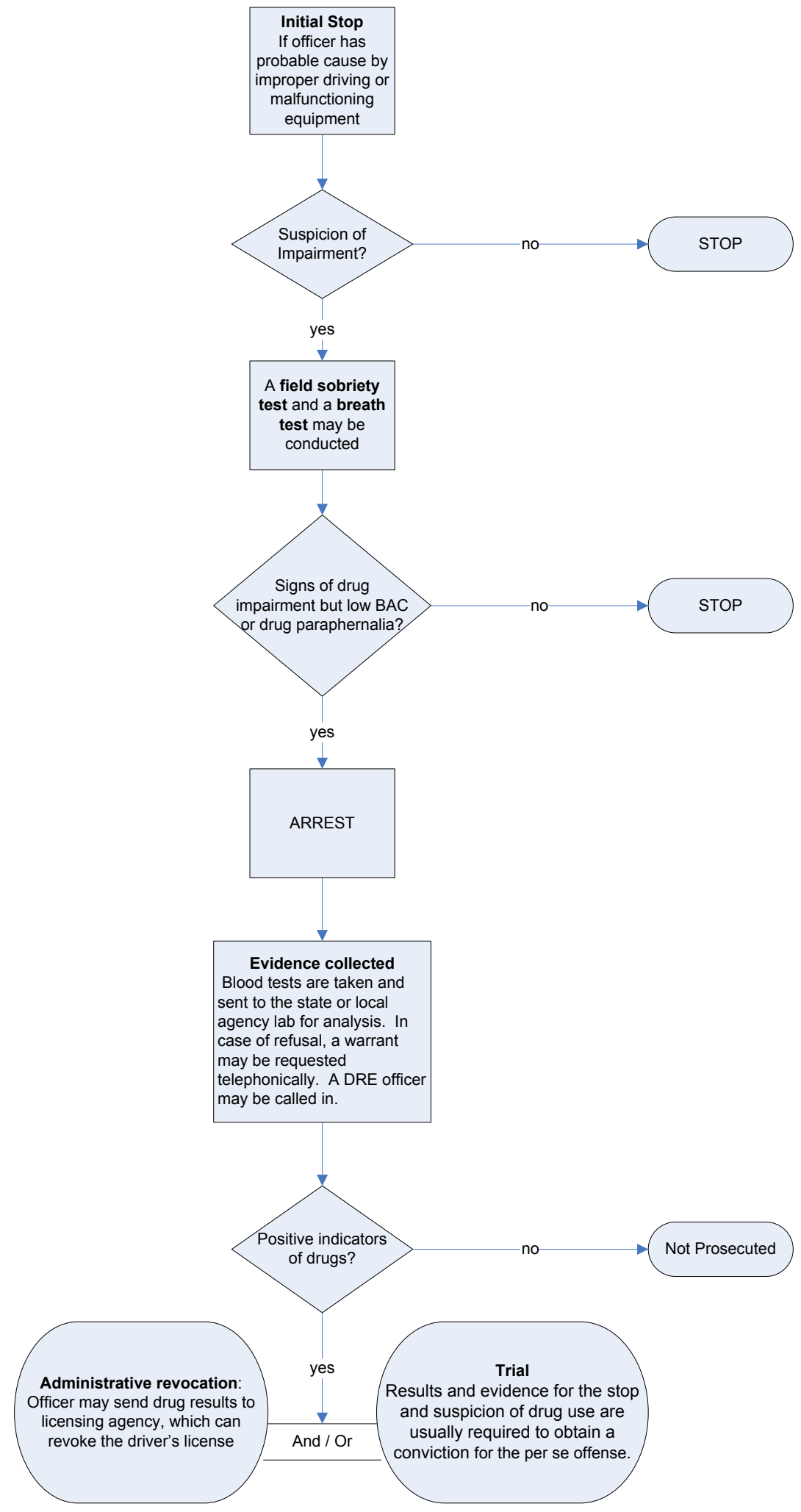

Figure 22. Minnesota Flowchart 


\section{Data}

Data for DRE Evaluations for the State of Minnesota were obtained from the National DRE Database. The IACP reported there were 164 DREs in Minnesota at the end of 2007. DWIalcohol arrest data, DWI-Alcohol (DWI-A) conviction data, and DWID conviction data were obtained from the Minnesota Office of Traffic Safety's Impaired Driving Facts Report.

Table 25. Minnesota's Summary Data on DWID and DWI-A Actions

\begin{tabular}{|c|c|c|c|c|c|c|}
\hline Year & $\begin{array}{c}\text { DRE } \\
\text { Evaluations }\end{array}$ & $\begin{array}{c}\text { DWID } \\
\text { Arrests }^{*}\end{array}$ & $\begin{array}{c}\text { DWID } \\
\text { Convictions }\end{array}$ & $\begin{array}{l}\text { DWID Lesser } \\
\text { Offense } \\
\text { Convictions* }\end{array}$ & $\begin{array}{c}\text { DWI-A } \\
\text { Arrests }\end{array}$ & $\begin{array}{c}\text { DWI-A } \\
\text { Convictions }\end{array}$ \\
\hline 2005 & 350 & & & & & \\
\hline 2004 & 292 & & 681 & & 36,888 & 27,907 \\
\hline 2003 & 246 & & 528 & & 35,012 & 26,210 \\
\hline 2002 & 365 & & 404 & & 36,339 & 27,447 \\
\hline 2001 & 549 & & 397 & & 36,833 & 27,981 \\
\hline 2000 & 566 & & 334 & & 38,656 & 29,292 \\
\hline 1999 & 316 & & 207 & & 38,278 & 29,314 \\
\hline 1998 & 203 & & 218 & & 35,688 & 27,136 \\
\hline 1997 & 299 & & 128 & & 34,260 & 26,269 \\
\hline 1996 & 168 & & 50 & & 33,122 & 25,718 \\
\hline 1995 & 94 & & 25 & & 32,030 & 25,139 \\
\hline 1994 & 89 & & 14 & & 31,154 & 24,834 \\
\hline 1993 & 97 & & 10 & & 30,690 & 25,107 \\
\hline 1992 & 105 & & 10 & & 30,861 & 25,338 \\
\hline 1991 & 53 & & 6 & & 32,439 & 25,860 \\
\hline
\end{tabular}

* Data not available

Minnesota reports DWID convictions separate from alcohol-related DWI cases, as shown in the table above. Data subsequent to its 2006 adoption of a drug per se law are not yet available, but there is a clear ascending trend in DWID convictions from 1991 through 2004 and DWID conviction numbers are rising much more quickly than those for DWI alcohol. 


\section{Nevada}

\section{State with Drug Per Se Law and Active DRE Program}

\section{Summary of Nevada's Drug Per Se Law}

Nevada has a per se drugged driving law enacted for controlled substances, certain chemicals, poisons, organic solvents and compounds (Nevada Revised Statutes 484.379).

Nevada law calls for 6 months imprisonment (2 days mandatory), $\$ 1,000$ fine ( $\$ 400$ mandatory), and 90 days (45 days mandatory) revocation for first offense.

\section{Effective Date}

Nevada's drug per se law took effect on September 23, 2003

\section{Drug Per Se Law}

Nev. Rev. Stat. $\S 484.379$. Driving under the influence of intoxicating liquor or controlled or prohibited substance.

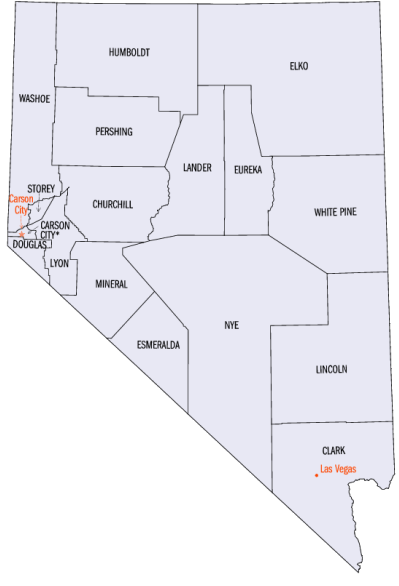

Figure 23. Nevada

(1.) It is unlawful for any person who:

(a) Is under the influence of intoxicating liquor;

(b) Has a concentration of alcohol of 0.08 or more in his blood or breath; or

(c) Is found by measurement within 2 hours after driving or being in actual physical control of a vehicle to have a concentration of alcohol of 0.08 or more in his blood or breath, to drive or be in actual physical control of a vehicle on a highway or on premises to which the public has access.

(2.) It is unlawful for any person who:

(a) Is under the influence of a controlled substance;

(b) Is under the combined influence of intoxicating liquor and a controlled substance; or

(c) Inhales, ingests, applies or otherwise uses any chemical, poison or organic solvent, or any compound or combination of any of these, to a degree which renders him incapable of safely driving or exercising actual physical control of a vehicle, to drive or be in actual physical control of a vehicle on a highway or on premises to which the public has access. The fact that any person charged with a violation of this subsection is or has been entitled to use that drug under the laws of this State is not a defense against any charge of violating this subsection.

(3.)It is unlawful for any person to drive or be in actual physical control of a vehicle on a highway or on premises to which the public has access with an amount of a prohibited substance in his blood or urine that is equal to or greater than: 
Prohibited Substance

(a) Amphetamine

(b) Cocaine

(c) Cocaine metabolite

(d) Heroin

(e) Heroin metabolite

(1) Morphine

(2) 6-monoacetyl Morphine

(f) Lysergic Acid Diethylamide 25

(g) Marijuana

(h) Marijuana Metabolite

(i) Methamphetamine

(j) Phencycladine
Urine

Nanograms Per Milliliter

500

150

150

2,000

2,000

10

25

10

15

500

25
Blood

Nanograms Per Milliliter

100

50

50

50

50

10

10

2

5

100

10

\section{Drug Specifics}

Drugs covered include specific controlled substances, certain chemicals, poisons, organic solvents and compounds at specific minimum concentrations. A detailed list appears in Appendix B.

Statutory Sanctions

Table 26. Nevada Statutory Sanctions

\begin{tabular}{|c|c|c|c|c|c|}
\hline State & $\begin{array}{c}\text { Drug Per } \\
\text { Se Law }\end{array}$ & $\begin{array}{c}\text { DRE } \\
\text { Program } \\
\end{array}$ & Effective Date & Law & Sanctions for First Offense \\
\hline \multirow{3}{*}{ NV } & \multirow{3}{*}{ Yes } & \multirow{3}{*}{ Yes } & \multirow{3}{*}{$\begin{array}{l}\text { September 23, } \\
2003\end{array}$} & \multirow{3}{*}{$\begin{array}{l}\text { Nevada has a per } \\
\text { se drugged } \\
\text { driving law } \\
\text { enacted for } \\
\text { controlled } \\
\text { substances, } \\
\text { certain chemicals, } \\
\text { poisons, organic } \\
\text { solvents and } \\
\text { compounds } \\
\text { (Nevada Revised } \\
\text { Statutes 484.379). }\end{array}$} & $\begin{array}{l}\text { Criminal: } 2 \text { days (mandatory) to } 6 \text { months } \\
\text { imprisonment, } \$ 400 \text { (mandatory) to } \\
\$ 1,000 \text { fine for } 1 \text { st offense. }\end{array}$ \\
\hline & & & & & $\begin{array}{l}\text { Court-Ordered Other: The court may } \\
\text { order participation in a drug treatment } \\
\text { program ( } 6 \text { months mandatory for } 1 \text { st } \\
\text { offense. The court may order community } \\
\text { service (of varying mandatory lengths) in } \\
\text { lieu of or in addition to jail time. The court } \\
\text { may also order restitution either directly to } \\
\text { a victim or to the Victim's Compensation } \\
\text { Fund, and residential confinement with or } \\
\text { without electronic monitoring. The } \\
\text { defendant must be ordered to pay various } \\
\text { fines, fees, and assessments and to } \\
\text { attend a meeting with DUI victims to } \\
\text { discuss the impact of DUI on victims. }\end{array}$ \\
\hline & & & & & $\begin{array}{l}\text { Administrative: Unspecified revocation } \\
\text { authorized for zero tolerance violations; } \\
90 \text { days ( } 45 \text { days mandatory) revocation } \\
\text { for } 1 \text { st } D U \text { Ul offense. }\end{array}$ \\
\hline
\end{tabular}


Criminal: 2 days (mandatory) to 6 months imprisonment, $\$ 400$ (mandatory) to $\$ 1,000$ fine for first offense; 10 days (mandatory) to 6 months, $\$ 750$ (mandatory) to $\$ 1,000$ for second offense within 7 years; 1 year (mandatory) to 6 years, $\$ 2,000$ (mandatory) to $\$ 5,000$ for third and subsequent offense within 7 years (felony).

Court-Ordered Other: The court may order participation in a drug treatment program (6 months mandatory for first offense, 1 year mandatory for second offense) in exchange for a suspended sentence. The court may order community service (of varying mandatory lengths) in lieu of or in addition to jail time. The court may also order restitution either directly to a victim or to the Victim's Compensation Fund, and residential confinement with or without electronic monitoring. The defendant must be ordered to pay various fines, fees, and assessments and to attend a meeting with DUI victims to discuss the impact of DUI on victims.

Administrative: Unspecified revocation authorized for zero-tolerance violations; 90 days (45 days mandatory) revocation for first DUI offense; 1 year (mandatory) revocation for second DUI offense within 7 years; 3 years (18 months mandatory) revocation for third DUI and subsequent DUI offenses within 7 years. 
Implementation and Handling of Nevada's DUID Cases

An officer must have reasonable suspicion developed by observing improper driving or an equipment violation in order to make the initial stop. If, in contact with the driver, reasonable grounds of alcohol or drug impairment is developed, the officer pursues further investigation.

If the driver shows physical impairment and a low BAC, or there are obvious signs of drug use (drug paraphernalia, etc.) apparent, the driver is arrested and the officer takes the subject to an evidential testing facility.

A DRE may be called in to do an evaluation or the arresting officer may gather additional information. The IACP reported there were 104 DREs in Nevada at the end of 2007.

Typically, blood samples are taken and sent to the State or local agency lab for analysis.

If drug results are positive, the officer may send them to the licensing agency, which can then administratively revoke the driver's license.

In Nevada, there is no right to refuse the chemical test. If a subject attempts to refuse, the officer may compel the subject to submit to a breath, urine, or blood test at the officer's discretion.

At trial, the presence of the drug and evidence for the stop and suspicion of drug use are usually

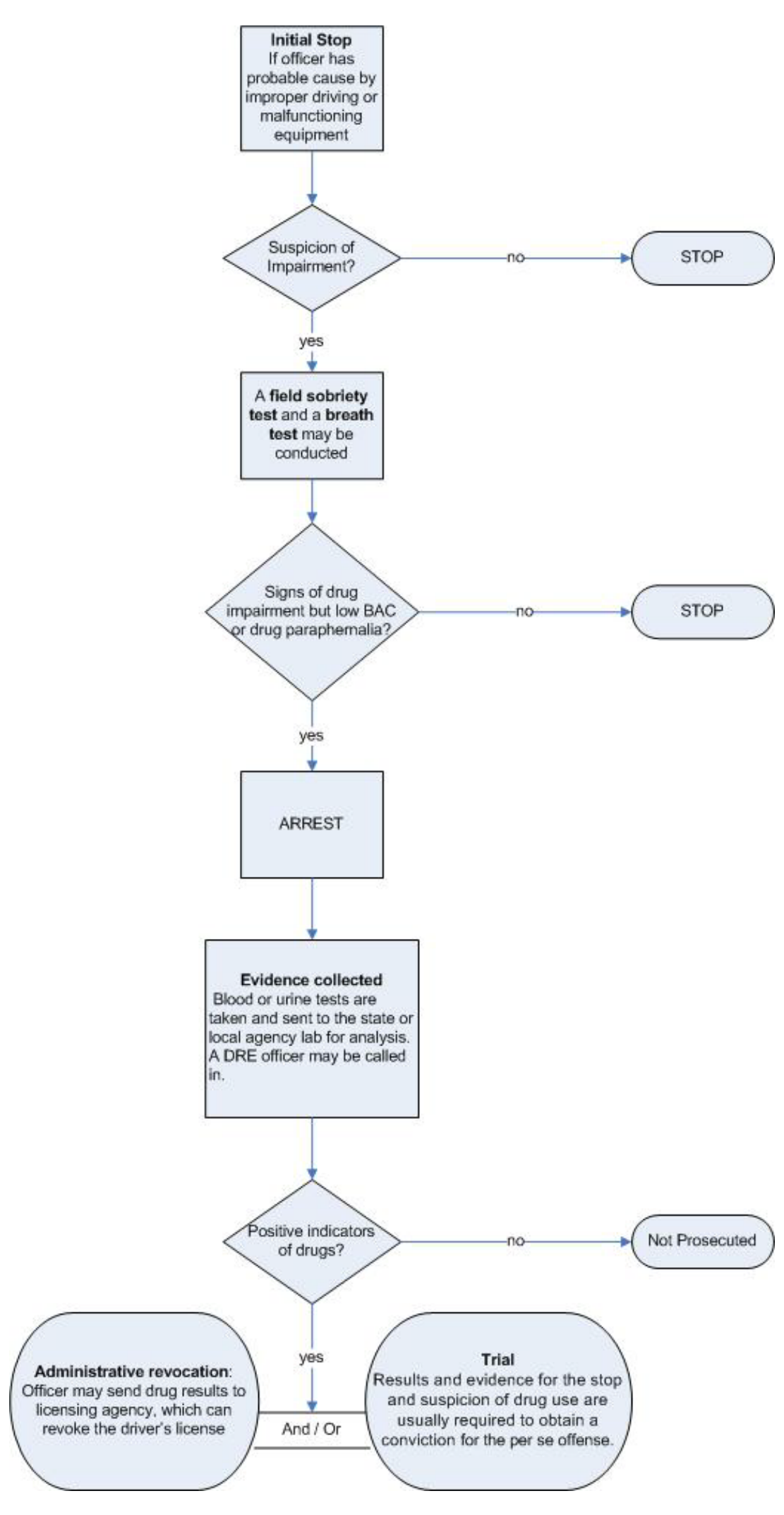

Figure 24. Nevada Flowchart 
required to obtain a conviction.

Nevada's official records do not readily distinguish between the DUID and DUI-alcohol arrest and disposition.

\section{Data}

In Nevada, statewide data on DUID arrests is not available. However, the Las Vegas Metropolitan Police Department maintains a database that can distinguish between DUID, DUI alcohol, and DUI for the combination of both alcohol and other drugs. The drug per se law took effect September 23, 2003. Nevada DUI-Alcohol (DUI-A) arrest data were obtained from the FBI Arrest Statistics.

Table 27. Nevada's Summary Data on DUID and DUI-A Actions

\begin{tabular}{|c|c|c|c|c|c|}
\hline Year & $\begin{array}{c}\text { DRE } \\
\text { Evaluations* }\end{array}$ & $\begin{array}{c}\text { DUID } \\
\text { Arrests* }\end{array}$ & $\begin{array}{c}\text { DUID } \\
\text { Convictions* }\end{array}$ & $\begin{array}{l}\text { DUID Lesser } \\
\text { Offense } \\
\text { Convictions* }\end{array}$ & $\begin{array}{r}\text { DUI-A } \\
\text { Arrests }\end{array}$ \\
\hline \multicolumn{6}{|l|}{2005} \\
\hline 2004 & & & & & 9,551 \\
\hline 2003* & & & & & 8,397 \\
\hline 2002 & & & & & 9,159 \\
\hline 2001 & & & & & 8,990 \\
\hline
\end{tabular}

DUID and DUI-alcohol arrest data for Las Vegas were obtained from the Las Vegas Metropolitan Police Department's TARGET/DUI Database, a locally maintained database on impaired-driving arrests.

Table 28. Las Vegas, Nevada's Summary Data on DUID and DUI-A Actions

\begin{tabular}{|c|c|c|c|c|c|c|}
\hline Year & $\begin{array}{c}\text { DRE } \\
\text { Evaluations* } \\
\end{array}$ & $\begin{array}{c}\text { DUID } \\
\text { Arrests } \\
\end{array}$ & $\begin{array}{c}\text { DUID } \\
\text { Convictions* } \\
\end{array}$ & $\begin{array}{l}\text { DUID Lesser } \\
\text { Offense } \\
\text { Convictions* }\end{array}$ & $\begin{array}{l}\text { Arrests } \\
\text { for both } \\
\text { DUI-A } \\
\text { and } \\
\text { DUID } \\
\end{array}$ & $\begin{array}{r}\text { DUI-A } \\
\text { Arrests } \\
\end{array}$ \\
\hline 2006 & & 313 & & & 117 & 4,629 \\
\hline 2005 & & 231 & & & 103 & 3,913 \\
\hline 2004 & & 214 & & & 150 & 3,584 \\
\hline $2003^{* *}$ & & 217 & & & 128 & 3,136 \\
\hline 2002 & & 206 & & & 85 & 2,925 \\
\hline 2001 & & 134 & & & 53 & 1,953 \\
\hline
\end{tabular}

As can be seen in Table 28, the Las Vegas Metropolitan Police Department tracks DUID cases which also involve alcohol separately from the drugs-alone cases. It appears the volume of drugrelated cases has been increasing gradually. In Las Vegas, there was not a dramatic rise in either category of drug per se arrest until 2006, when the number of arrests for the drugs-alone charge increased. For the combination offense of both DUID and DUI-A, there was an increase in 2004 
followed by lower levels of activity in 2004 and 2005. Comparing 2006 with 2002, the last full year before the implementation of the law, there were nearly 52\% more DUID (drugs alone) arrests made in 2006 , and nearly $38 \%$ more cases combining alcohol and other drugs. This compared with a $58 \%$ increase in DUI alcohol arrests. Therefore, there is a marked increase in DUID arrest activity, but it is paralleled by a similar, if not greater, increase in DUI alcohol arrests. 


\section{Ohio}

\section{State with Drug Per Se Law and DRE Activity}

\section{Summary of Ohio's Drug Per Se Law}

Ohio has a per se drugged driving law enacted for controlled substances (Ohio Revised Code Section 4511.19).

OUID first offense is the same as for OUI first offense. Ohio law calls for a 72-hour mandatory imprisonment, up to six months in jail, a $\$ 1,000$ fine, and license suspension of 6 months (mandatory) up to three years.

\section{Effective Date}

Ohio's drug per se law took effect on August 17, 2006.

\section{Drug Per Se Law}

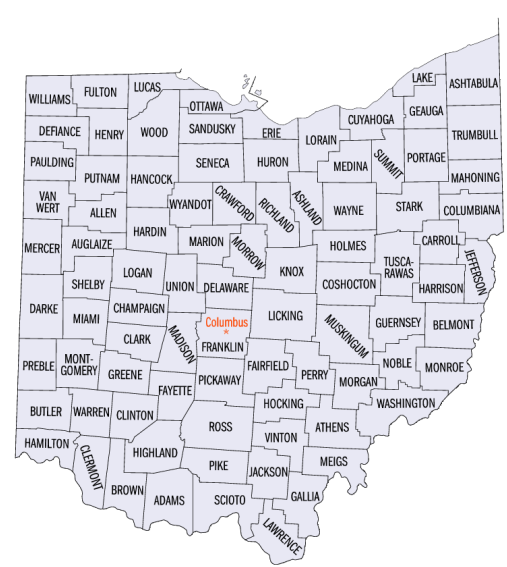

Figure 25. Ohio

\section{Ohio Rev. Code $§$ 4511.19(A)}

(1) No person shall operate any vehicle, streetcar, or trackless trolley within this State, if, at the time of the operation, any of the following apply:

(a) The person is under the influence of alcohol, a drug of abuse, or a combination of them.

(b) The person has a concentration of eight-hundredths of one per cent or more but less than seventeen-hundredths of one per cent by weight per unit volume of alcohol in the person's whole blood.

(c) The person has a concentration of ninety-six-thousandths of one per cent or more but less than two hundred four-thousandths of one per cent by weight per unit volume of alcohol in the person's blood serum or plasma.

(d) The person has a concentration of eight-hundredths of one gram or more but less than seventeen-hundredths of one gram by weight of alcohol per two hundred ten liters of the person's breath.

(e) The person has a concentration of eleven-hundredths of one gram or more but less than two hundred thirty-eight-thousandths of one gram by weight of alcohol per one hundred milliliters of the person's urine.

(f) The person has a concentration of seventeen-hundredths of one per cent or more by weight per unit volume of alcohol in the person's whole blood.

(g) The person has a concentration of two hundred four-thousandths of one per cent or more by weight per unit volume of alcohol in the person's blood serum or plasma.

(h) The person has a concentration of seventeen-hundredths of one gram or more by weight of alcohol per two hundred ten liters of the person's breath.

(i) The person has a concentration of two hundred thirty-eight-thousandths of one gram or more by weight of alcohol per one hundred milliliters of the person's urine. 
(j) Except as provided in division $(\mathrm{K})$ of this section, the person has a concentration of any of the following controlled substances or metabolites of a controlled substance in the person's whole blood, blood serum or plasma, or urine that equals or exceeds any of the following:

(i) The person has a concentration of amphetamine in the person's urine of at least five hundred nanograms of amphetamine per milliliter of the person's urine or has a concentration of amphetamine in the person's whole blood or blood serum or plasma of at least one hundred nanograms of amphetamine per milliliter of the person's whole blood or blood serum or plasma.

(ii) The person has a concentration of cocaine in the person's urine of at least one hundred fifty nanograms of cocaine per milliliter of the person's urine or has a concentration of cocaine in the person's whole blood or blood serum or plasma of at least fifty nanograms of cocaine per milliliter of the person's whole blood or blood serum or plasma.

(iii) The person has a concentration of cocaine metabolite in the person's urine of at least one hundred fifty nanograms of cocaine metabolite per milliliter of the person's urine or has a concentration of cocaine metabolite in the person's whole blood or blood serum or plasma of at least fifty nanograms of cocaine metabolite per milliliter of the person's whole blood or blood serum or plasma.

(iv) The person has a concentration of heroin in the person's urine of at least two thousand nanograms of heroin per milliliter of the person's urine or has a concentration of heroin in the person's whole blood or blood serum or plasma of at least fifty nanograms of heroin per milliliter of the person's whole blood or blood serum or plasma.

(v) The person has a concentration of heroin metabolite (6-monoacetyl morphine) in the person's urine of at least ten nanograms of heroin metabolite (6-monoacetyl morphine) per milliliter of the person's urine or has a concentration of heroin metabolite (6-monoacetyl morphine) in the person's whole blood or blood serum or plasma of at least ten nanograms of heroin metabolite (6-monoacetyl morphine) per milliliter of the person's whole blood or blood serum or plasma.

(vi) The person has a concentration of L.S.D. in the person's urine of at least twenty-five nanograms of L.S.D. per milliliter of the person's urine or a concentration of L.S.D. in the person's whole blood or blood serum or plasma of at least ten nanograms of L.S.D. per milliliter of the person's whole blood or blood serum or plasma.

(vii) The person has a concentration of marihuana in the person's urine of at least ten nanograms of marihuana per milliliter of the person's urine or has a concentration of marihuana in the person's whole blood or blood serum or plasma of at least two nanograms of marihuana per milliliter of the person's whole blood or blood serum or plasma.

(viii) Either of the following applies:

(I) The person is under the influence of alcohol, a drug of abuse, or a combination of them, and, as measured by gas chromatography mass 
spectrometry, the person has a concentration of marihuana metabolite in the person's urine of at least fifteen nanograms of marihuana metabolite per milliliter of the person's urine or has a concentration of marihuana metabolite in the person's whole blood or blood serum or plasma of at least five nanograms of marihuana metabolite per milliliter of the person's whole blood or blood serum or plasma.

(II) As measured by gas chromatography mass spectrometry, the person has a concentration of marihuana metabolite in the person's urine of at least thirty-five nanograms of marihuana metabolite per milliliter of the person's urine or has a concentration of marihuana metabolite in the person's whole blood or blood serum or plasma of at least fifty nanograms of marihuana metabolite per milliliter of the person's whole blood or blood serum or plasma.

(ix) The person has a concentration of methamphetamine in the person's urine of at least five hundred nanograms of methamphetamine per milliliter of the person's urine or has a concentration of methamphetamine in the person's whole blood or blood serum or plasma of at least one hundred nanograms of methamphetamine per milliliter of the person's whole blood or blood serum or plasma.

(x) The person has a concentration of phencyclidine in the person's urine of at least twenty-five nanograms of phencyclidine per milliliter of the person's urine or has a concentration of phencyclidine in the person's whole blood or blood serum or plasma of at least ten nanograms of phencyclidine per milliliter of the person's whole blood or blood serum or plasma.

\section{Drug Specifics}

The specific drugs covered are detailed in the summary of the law above.

\section{Statutory Sanctions}

Table 29. Ohio Statutory Sanctions

\begin{tabular}{|c|c|c|c|c|c|}
\hline State & $\begin{array}{c}\text { Drug Per } \\
\text { Se Law }\end{array}$ & $\begin{array}{c}\text { DRE } \\
\text { Program }\end{array}$ & Effective Date & Law & Sanctions for First Offense \\
\hline & & & & $\begin{array}{l}\text { Ohio has a per se } \\
\text { drugged driving } \\
\text { law enacted for } \\
\text { controlled }\end{array}$ & $\begin{array}{l}\text { Criminal: Not more than } 6 \text { months ( } 3 \\
\text { consecutive days mandatory) } \\
\text { imprisonment or education program } \\
\text { and } \$ 250 \text { (mandatory) to } \$ 1,000 \text { fine } \\
\text { for } 1 \text { st offense. }\end{array}$ \\
\hline OH & Yes & Yes & August 11,2006 & $\begin{array}{l}\text { substances (Ohio } \\
\text { Revised Code } \\
\text { Section 4511.19). }\end{array}$ & $\begin{array}{l}\text { Administrative: } 6 \text { months (mandatory } \\
\text { to } 3 \text { years for } 1 \text { st offense. In addition, } \\
\text { attendance at a drivers "intervention" } \\
\text { program and a drug and alcohol } \\
\text { treatment program may be required. }\end{array}$ \\
\hline
\end{tabular}

Criminal: Not more than 6 months ( 3 consecutive days mandatory) imprisonment or education program and $\$ 250$ (mandatory) to $\$ 1,000$ fine for first offense; 10 days (mandatory) 
imprisonment or home detention to 6 months and $\$ 350$ (mandatory) to $\$ 1,000$ for second offense within 6 years; 30 days (mandatory) imprisonment or home detention to 1 year imprisonment and $\$ 550$ (mandatory) to $\$ 2,500$ for third and subsequent offense within 6 years.

Administrative: 6 months (mandatory) to 3 years for first offense; 1 year (mandatory) to 5 years suspension for second offense; 1 year (mandatory) to 10 years suspension for third offense. In addition, attendance at a drivers "intervention" program and a drug and alcohol treatment program may be required. 


\section{Implementation and Handling of Ohio's OUID Cases}

An officer must develop probable cause by observing improper driving or an equipment violation in order to make the initial stop. If, in contact with the driver, the officer develops reasonable suspicion of alcohol or drug impairment, then the officer pursues further investigation.

If the driver shows physical impairment and a low BAC, or there are obvious signs of drug use (drug paraphernalia, etc.) apparent, the driver is arrested and the officer gathers further information.

A DRE may be called in to do an evaluation or the arresting officer may gather additional information. The IACP reported there were 4 DREs in Ohio at the end of 2007.

Typically, the officer requests blood samples and they are sent to the State or local agency lab for analysis.

In case of refusal, an officer requests a warrant telephonically and a sample is taken, usually at a hospital in metropolitan areas, but sometimes by an officer who has had phlebotomy training.

If drug results are positive, the officer may send them to the licensing agency, which can then administratively revoke the driver's license.

At trial, the presence of the drug and evidence for the stop and suspicion of drug use are

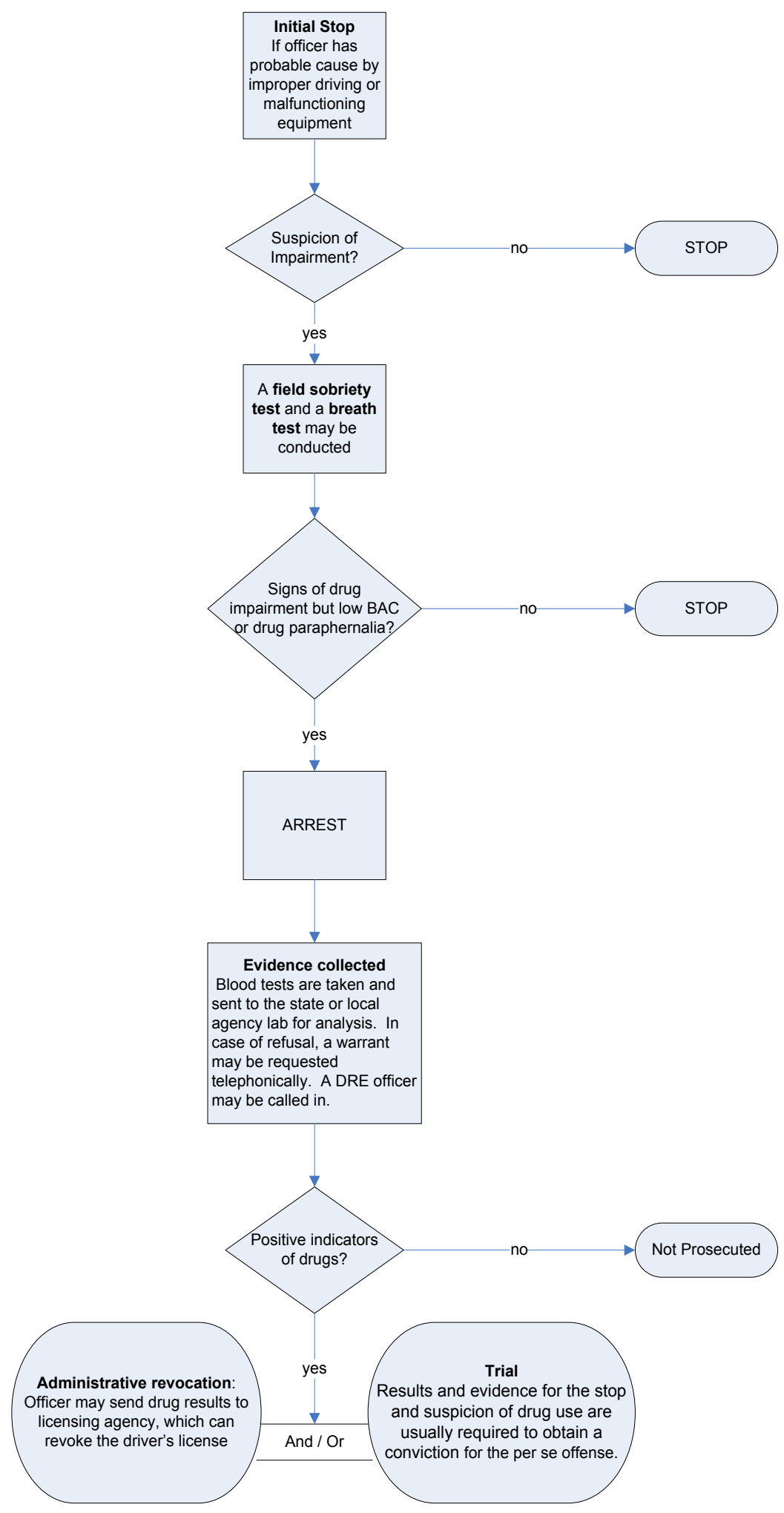

Figure 26. Ohio Flowchart 
usually required to obtain a conviction.

Ohio's official records do not readily distinguish between the OUID and OUI-alcohol arrest and disposition.

\section{Data}

The OUI-alcohol (OUI-A) arrest data was obtained from the 2004 and 2006 Ohio Courts Summaries, which are published by the Supreme Court of Ohio.

Table 30. Ohio's Summary Data on OUID and OUI Actions

\begin{tabular}{|c|c|c|c|c|c|}
\hline Year & $\begin{array}{c}\text { DRE } \\
\text { Evaluations* }\end{array}$ & $\begin{array}{c}\text { OUID } \\
\text { Arrests* }\end{array}$ & $\begin{array}{c}\text { OUID } \\
\text { Convictions* }\end{array}$ & $\begin{array}{l}\text { OUID Lesser } \\
\text { Offense } \\
\text { Convictions* }\end{array}$ & $\begin{array}{c}\text { OUI-A } \\
\text { Arrests }^{*}\end{array}$ \\
\hline 2005 & & & & & 62,170 \\
\hline 2004 & & & & & 61,784 \\
\hline 2003 & & & & & 64,360 \\
\hline 2002 & & & & & 65,376 \\
\hline 2001 & & & & & 63,574 \\
\hline 2000 & & & & & 65,620 \\
\hline
\end{tabular}

The currently available data do not provide any potential insight into the effects of Ohio's drug per se law because the law implementation date, August 17th, 2006, was subsequent to the last data currently available and OUI-D cases are not distinguished from other impaired-driving cases. 


\section{Pennsylvania}

\section{State With Drug Per Se Law and Active}

DRE Program

\section{Summary of Pennsylvania's Drug Per Se Law}

Pennsylvania has a per se drugged driving law enacted for controlled substances that prohibits driving with Schedule I and unprescribed Schedule II or III substances or their metabolites (75 Pennsylvania Consolidated Statutes 3802).

Up to 6 months probation and $\$ 300$ mandatory

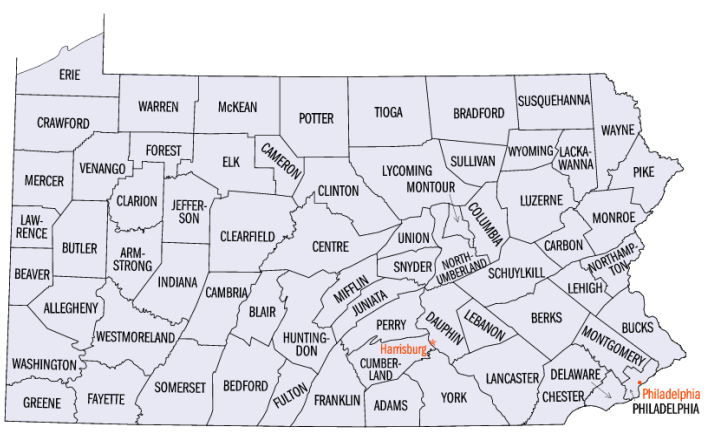
fine for first offense as well as attendance at a drug education program. Community service and attendance at a treatment program may be ordered.

\section{Effective Date}

Pennsylvania's drug per se law took effect on February 1, 2004.

\section{Drug Per Se Law}

\section{P.A. C.S. $§ 3802$}

(a) General impairment.

(1) An individual may not drive, operate or be in actual physical control of the movement of a vehicle after imbibing a sufficient amount of alcohol such that the individual is rendered incapable of safely driving, operating or being in actual physical control of the movement of the vehicle.

(2) An individual may not drive, operate or be in actual physical control of the movement of a vehicle after imbibing a sufficient amount of alcohol such that the alcohol concentration in the individual's blood or breath is at least 0.08 percent but less than 0.10 percent within two hours after the individual has driven, operated or been in actual physical control of the movement of the vehicle.

(b) High rate of alcohol.--An individual may not drive, operate or be in actual physical control of the movement of a vehicle after imbibing a sufficient amount of alcohol such that the alcohol concentration in the individual's blood or breath is at least 0.10 percent but less than 0.16 percent within two hours after the individual has driven, operated or been in actual physical control of the movement of the vehicle.

(c) Highest rate of alcohol.--An individual may not drive, operate or be in actual physical control of the movement of a vehicle after imbibing a sufficient amount of alcohol such that the alcohol concentration in the individual's blood or breath is 0.16 percent or higher within two hours after the individual has driven, operated or been in actual physical control of the movement of the vehicle.

(d) Controlled substances.--An individual may not drive, operate or be in actual physical control of the movement of a vehicle under any of the following circumstances: 
(1) There is in the individual's blood any amount of a:

(i) Schedule I controlled substance, as defined in the act of April 14, 1972 (P.L. 233, No. 64), known as The Controlled Substance, Drug, Device and Cosmetic Act;

(ii) Schedule II or Schedule III controlled substance, as defined in The Controlled Substance, Drug, Device and Cosmetic Act, which has not been medically prescribed for the individual; or

(iii) Metabolite of a substance under subparagraph (i) or (ii).

(2) The individual is under the influence of a drug or combination of drugs to a degree that impairs the individual's ability to safely drive, operate or be in actual physical control of the movement of the vehicle.

(3) The individual is under the combined influence of alcohol and a drug or combination of drugs to a degree that impairs the individual's ability to safely drive, operate or be in actual physical control of the movement of the vehicle.

(4) The individual is under the influence of a solvent or noxious substance in violation of 18 Pa.C.S. $§ 7303$ (relating to sale or illegal use of certain solvents and noxious substances).

\section{Drug Specifics}

Drugs covered by the include Schedule I controlled substances, non-prescribed Schedule II or III controlled substances, or their metabolites. A detailed listing appears in Appendix B.

\section{Statutory Sanctions}

Table 31. Pennsylvania Statutory Sanctions

\begin{tabular}{|c|c|c|c|c|c|}
\hline State & $\begin{array}{c}\text { Drug Per } \\
\text { Se Law }\end{array}$ & $\begin{array}{c}\text { DRE } \\
\text { Program }\end{array}$ & Effective Date & Law & Sanctions for First Offense \\
\hline PA & Yes & Yes & $\begin{array}{l}\text { February 1, } \\
2004\end{array}$ & $\begin{array}{l}\text { Pennsylvania has } \\
\text { a per se drugged } \\
\text { driving law } \\
\text { enacted for } \\
\text { controlled } \\
\text { substances } \\
\text { prohibits driving } \\
\text { with Schedule I } \\
\text { and unprescribed } \\
\text { Schedule II or III } \\
\text { substances or } \\
\text { their metabolites } \\
\text { (75 Pennsylvania } \\
\text { Consolidated } \\
\text { Statutes 3802). }\end{array}$ & $\begin{array}{l}\text { Criminal: Up to } 6 \text { months probation } \\
\text { and } \$ 300 \text { (mandatory) fine for } 1 \text { st } \\
\text { offense. } \\
\text { Court-Ordered Other: Up to } 150 \\
\text { hours of community service. The } \\
\text { court may order attendance at a } \\
\text { victim impact panel program and may } \\
\text { order "the restoration of the victim to } \\
\text { preoffense status or the protection of } \\
\text { the public." } \\
\text { Administrative: no suspension for first } \\
\text { offense if driver meets certain criteria; } \\
12 \text { month license suspension for } \\
\text { second or subsequent offense. In } \\
\text { addition, attendance at a drug } \\
\text { education is required and a treatment } \\
\text { program may be ordered. }\end{array}$ \\
\hline
\end{tabular}

Criminal: Up to 6 months probation and $\$ 300$ (mandatory) fine for first offense; 5 days (mandatory) to 6 months and $\$ 300$ (mandatory) to $\$ 2,000$ fine for second offense; 10 days (mandatory) to 2 years and $\$ 500$ (mandatory) to $\$ 5,000$ fine for third subsequent offense 
Court-Ordered Other: Up to 150 hours of community service. The court may order attendance at a victim impact panel program and may order "the restoration of the victim to preoffense status for the protection of the public."

Administrative: no suspension for first offense if driver meets certain criteria; 12-month license suspension for second or subsequent offense. In addition, attendance at a drug education is required and a treatment program may be ordered. 


\section{Implementation and Handling of Pennsylvania's DUID Cases}

An officer must develop probable cause by observing improper driving or an equipment violation in order to make the initial stop. If, in contact with the driver, the officer develops reasonable suspicion of alcohol or drug impairment, then the officer pursues further investigation.

If the driver shows physical impairment and a low BAC, or there are obvious signs of drug use (drug paraphernalia, etc.) apparent, the driver is arrested and the officer gathers further information.

A DRE may be called in to do an evaluation or the arresting officer may gather additional information.

Typically, the officer requests a blood sample from the driver and sends it to the State or local agency lab for analysis.

If drug results are positive, the officer may send them to the licensing agency, which can then administratively revoke the driver's license.

In case of refusal, a warrant is requested telephonically and a sample is taken, usually at a hospital in metropolitan areas, but sometimes by an officer who has had phlebotomy training.

At trial, the presence of the drug and evidence for the stop and suspicion of drug use are usually required to obtain a conviction.

Pennsylvania's official records do not readily distinguish between the DUID and DUI-alcohol arrest and

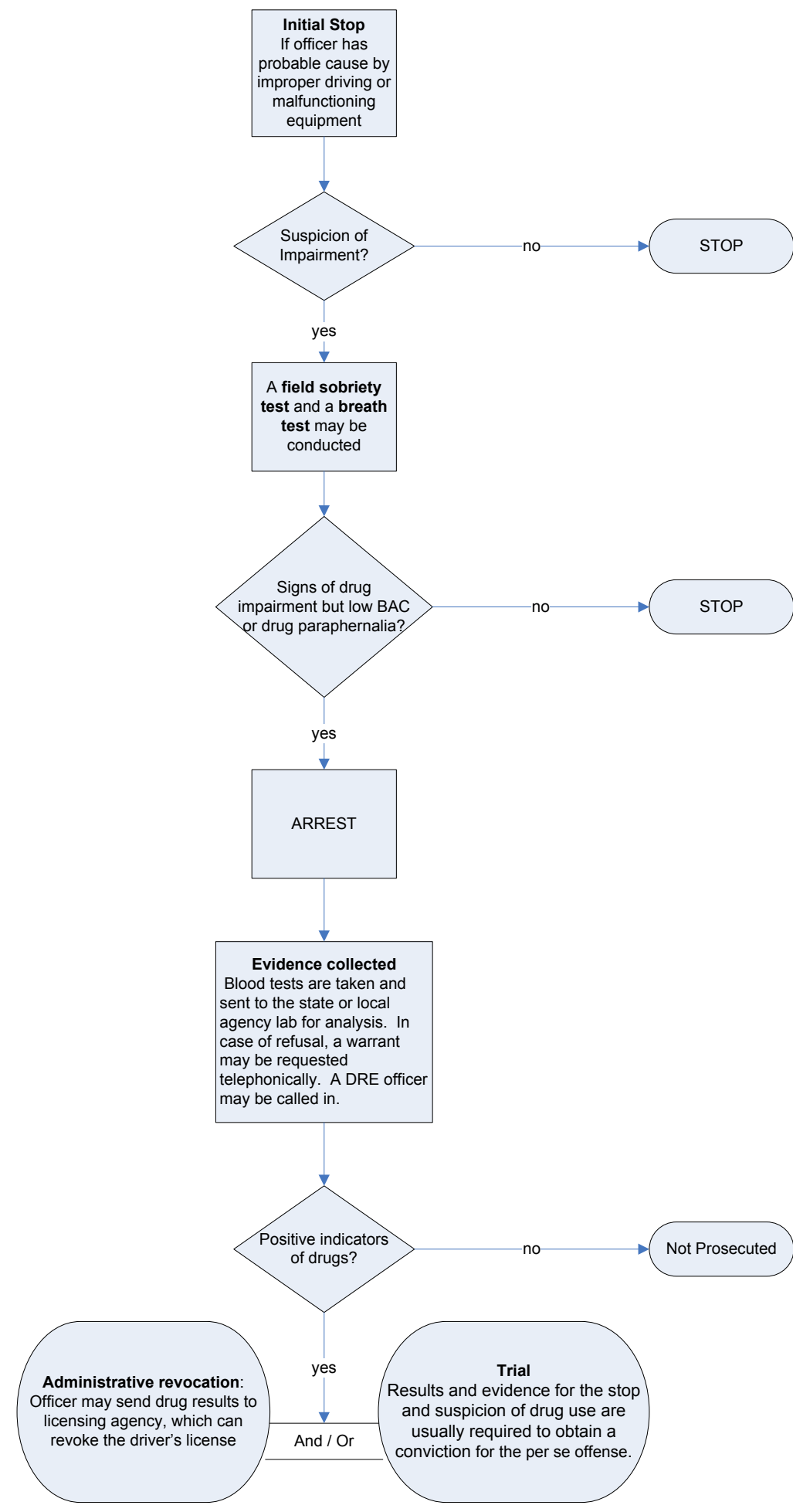

Figure 28. Pennsylvania Flowchart 
disposition.

\section{Data}

Data for DRE Evaluations for the State of Pennsylvania were obtained from the National DRE Database. DUI-Alcohol (DUI-A) arrest data were obtained from the State Uniform Crime Reporting System. DUID arrest data were obtained from the Administrative Office of Pennsylvania Courts. The IACP reported there were 35 DREs in Pennsylvania at the end of 2007.

Table 32. Pennsylvania's Summary Data on DUID and DUI Actions

\begin{tabular}{|c|c|c|c|c|c|}
\hline Year & $\begin{array}{c}\text { DRE } \\
\text { Evaluations }\end{array}$ & $\begin{array}{c}\text { DUID } \\
\text { Arrests* }\end{array}$ & $\begin{array}{c}\text { DUID } \\
\text { Convictions* }\end{array}$ & $\begin{array}{c}\text { DUID Lesser } \\
\text { Offense } \\
\text { Convictions* }\end{array}$ & $\begin{array}{c}\text { DUI-A } \\
\text { Arrests }\end{array}$ \\
\hline 2005 & 55 & 6,515 & & & 44,930 \\
\hline $2004^{* *}$ & & 5,529 & & & 44,156 \\
\hline 2003 & & & & & 42,054 \\
\hline 2002 & & & & & 42,095 \\
\hline
\end{tabular}




\section{Rhode Island}

\section{State with Drug Per Se Law and Active DRE Program}

\section{Summary of Rhode Island's Drug Per Se Law}

Rhode Island has a zero tolerance per se drugged driving law enacted for any drug, toluene, or any scheduled controlled substance (General Laws of Rhode Island, Section 31-27-2).

Rhode Island law calls or up to 12 months (no mandatory) imprisonment, a $\$ 100$ - $\$ 300$ fine (\$100 mandatory), and 30 - 100 days license suspension (30 days mandatory) for first offense.

\section{Effective Date}

Rhode Island's drug per se law took effect on July 1, 2006

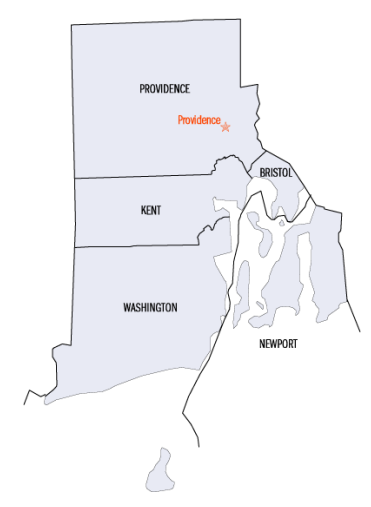

Figure 29. Rhode Island

\section{Drug Per Se Law}

\section{R.I. Gen. Laws § 31-27-2. Driving under the influence of alcohol or drugs.}

(a) Whoever drives or otherwise operates any vehicle in the State while under the influence of any intoxicating liquor, drugs, toluene, or any controlled substance as defined in chapter 28 of title 21, or any combination of these, shall be guilty of a misdemeanor except as provided in subdivision (d)(3) and shall be punished as provided in subsection (d) of this section.

(b) (1) Any person charged under subsection (a) of this section whose blood alcohol concentration is eight one-hundredths of one percent $(.08 \%)$ or more by weight as shown by a chemical analysis of a blood, breath, or urine sample shall be guilty of violating subsection (a) of this section. This provision shall not preclude a conviction based on other admissible evidence. Proof of guilt under this section may also be based on evidence that the person charged was under the influence of intoxicating liquor, drugs, toluene, or any controlled substance defined in chapter 28 of title 21 , or any combination of these, to a degree that rendered the person incapable of safely operating a vehicle. The fact that any person charged with violating this section is or has been legally entitled to use alcohol or a drug shall not constitute a defense against any charge of violating this section.

(b) (2) Whoever drives or otherwise operates any vehicle in the State with a blood presence of any scheduled controlled substance as defined within chapter 28 of title 21 , as shown by analysis of a blood or urine sample, shall be guilty of a misdemeanor and shall be punished as provided in subsection (d) of this section.

\section{Drug Specifics}

Any drug, toluene, or any scheduled controlled substance. 


\section{Statutory Sanctions}

Table 33. Rhode Island Statutory Sanctions

\begin{tabular}{|c|c|c|c|c|c|}
\hline State & $\begin{array}{c}\text { Drug Per } \\
\text { Se Law }\end{array}$ & $\begin{array}{c}\text { DRE } \\
\text { Program }\end{array}$ & Effective Date & Law & Sanctions for First Offense \\
\hline \multirow{2}{*}{ RI } & \multirow{2}{*}{ Yes } & \multirow{2}{*}{ Yes } & \multirow{2}{*}{ July 1, 2006} & \multirow{2}{*}{$\begin{array}{l}\text { Rhode Island has } \\
\text { a zero tolerance } \\
\text { per se drugged } \\
\text { driving law } \\
\text { enacted for any } \\
\text { drug, toluene, or } \\
\text { any scheduled } \\
\text { controlled } \\
\text { substance } \\
\text { (General Laws of } \\
\text { Rhode Island, } \\
\text { Section 31-27-2). }\end{array}$} & $\begin{array}{l}\text { Criminal: Not more than } 1 \text { year (no } \\
\text { mandatory) imprisonment and } \$ 100 \\
\text { (mandatory) to } \$ 300 \text { fine for } 1 \text { st } \\
\text { offense. } \\
\text { Court-Ordered Other: } 10 \text { to } 60 \text { hours } \\
\text { of community service must be } \\
\text { ordered for 1st offense. The court } \\
\text { must order restitution payable to the } \\
\text { Victim's Compensation Fund. } \\
\text { Forfeiture may also be ordered. }\end{array}$ \\
\hline & & & & & $\begin{array}{l}\text { Administrative: } 30 \text { days (mandatory) } \\
\text { to } 180 \text { days suspension for } 1 \text { st } \\
\text { offense. } 1 \text { year revocation for } \\
\text { conviction of a DUI Controlled } \\
\text { Substance offense; up to } 2 \text { years } \\
\text { revocation for } 1 \text { st Serious Injury DUI } \\
\text { offense. In addition, attendance at a } \\
\text { driver's education course and/or a } \\
\text { drug education or treatment program } \\
\text { may be required. }\end{array}$ \\
\hline
\end{tabular}

Criminal: Not more than 1 year (no mandatory) imprisonment and $\$ 100$ (mandatory) to $\$ 300$ fine for first offense; 10 days (mandatory) to 1 year and $\$ 400$ (mandatory) for second offense within 5 years; 6 months (mandatory) to 1 year (mandatory) to 3 years imprisonment and $\$ 400$ (mandatory) for third subsequent offense within 5 years.

Court-Ordered Other: 10 to 60 hours of community service must be ordered for first offense. The court must order restitution payable to the Victim's Compensation Fund. Forfeiture may also be ordered.

Administrative: 30 days (mandatory) to 180 days suspension for first offense; 1 year (mandatory) to 2 years suspension for second offense; 2 year (mandatory) to 3 years suspension for third offense. 1 year revocation for conviction of a DUI controlled substance offense; up to 2 years revocation for first serious injury DUI offense; up to 4 years revocation for second serious injury DUI offense; In addition, attendance at a driver education course and/or a drug education or treatment program may be required. 


\section{Implementation and Handling of Rhode Island's DUID Cases}

The officer must develop probable cause by observing improper driving or an equipment violation in order to make the initial stop. If, in contact with the driver, the officer develops reasonable suspicion of alcohol or drug impairment, then the officer pursues further investigation.

If the driver shows physical impairment and a low BAC, or there are obvious signs of drug use (drug paraphernalia, etc.) apparent, the driver is arrested and further information is gathered.

A DRE may be called in to do an evaluation or the arresting officer may gather additional information.

Typically, blood samples are taken and sent to the State or local agency lab for analysis.

If drug results are positive, the officer may send them to the licensing agency, which can then administratively revoke the driver's license.

In case of refusal, an officer requests a warrant telephonically and requests a sample, usually at a hospital in metropolitan areas, but sometimes by an officer who has had phlebotomy training.

At trial, the presence of the drug and evidence for the stop and suspicion of drug use are usually required to obtain a conviction.

Rhode Island's official records do not readily distinguish between the DUID and DUI-alcohol arrest and disposition.

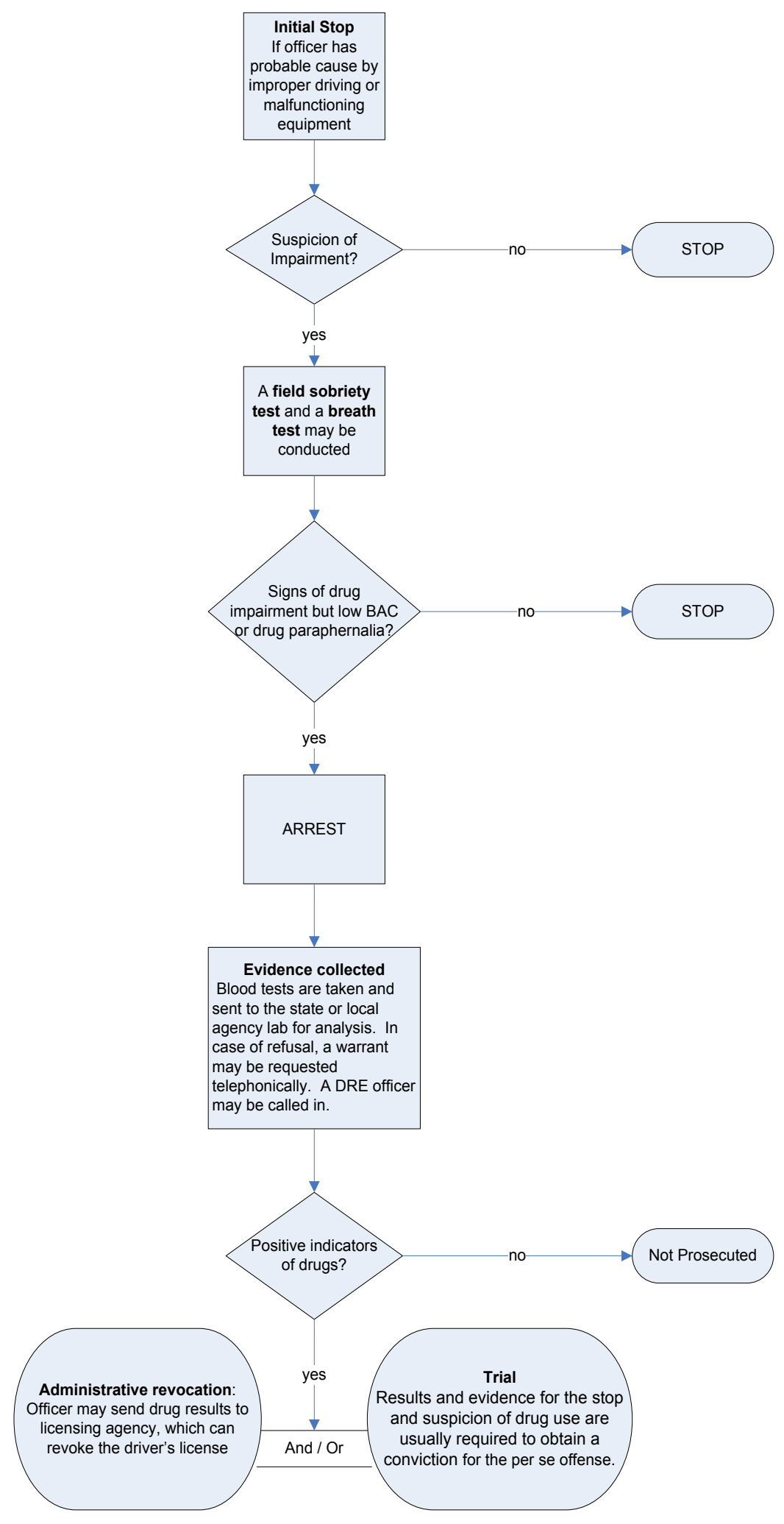

Figure 30. Rhode Island Flowchart 


\section{Data}

Rhode Island's DRE coordinator reported in 2004 there were 45 active DRE officers. The IACP reported there were 7 active DREs in Rhode Island at the beginning of 2007, but zero at the end of the year. The State coordinator has said they are in the process of recertifying some of the DREs. DUI-Alcohol (DUI-A) arrest data were obtained from the FBI Arrest Statistics.

Table 34. Rhode Island's Summary Data on DUID and DUI-A Actions

\begin{tabular}{|c|c|c|c|c|c|}
\hline Year & $\begin{array}{c}\text { DRE } \\
\text { Evaluations }\end{array}$ & $\begin{array}{c}\text { DUID } \\
\text { Arrests }^{*}\end{array}$ & $\begin{array}{c}\text { DUID } \\
\text { Convictions }\end{array}$ & $\begin{array}{l}\text { DUID Lesser } \\
\text { Offense } \\
\text { Convictions* }\end{array}$ & $\begin{array}{c}\text { DUI-A } \\
\text { Arrests }\end{array}$ \\
\hline \multicolumn{6}{|l|}{$2005^{* *}$} \\
\hline 2004 & & & & & 2,366 \\
\hline 2003 & & & & & 2,022 \\
\hline 2002 & & & & & 2,015 \\
\hline 2001 & & & & & 1,941 \\
\hline 2000 & & & & & 1,748 \\
\hline 1999 & & & & & 1,841 \\
\hline 1998 & & & & & 2,017 \\
\hline 1997 & & & & & 2,083 \\
\hline 1996 & & & & & 1,982 \\
\hline 1995 & & & & & 1,929 \\
\hline 1994 & & & & & 1,972 \\
\hline
\end{tabular}

Rhode Island's drug per se law took effect in 2005 and data are not yet available to potentially assess any effect the law may be having. Currently available data do not distinguish between DUID and DUI-alcohol offenses. 


\section{Utah}

\section{State With Drug Per Se Law and Active DRE Program}

\section{Summary of Utah's Drug Per Se Law}

Utah has a zero-tolerance per se drugged driving law enacted for any controlled substances or metabolite thereof. (Utah Code Section 41-6a-502, Section 41-6a-517). Involuntary or prescribed use is an affirmative defense.

Utah law calls for mandatory imprisonment of 48 hours and not more than 6 months upon conviction for a first offense. License suspension is 90 days for first offense.

\section{Effective Date}

Utah's drug per se law took effect on May 2, 1994.

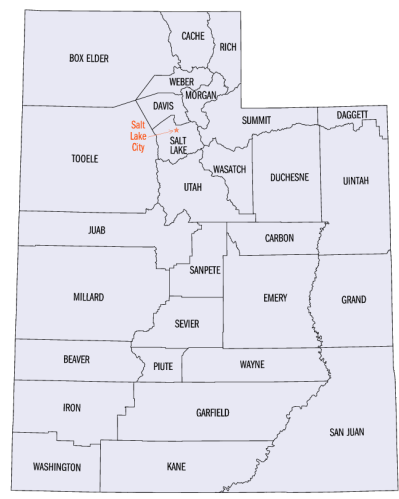

\section{Drug Per Se Law}

Utah Code Ann. $\$$ 41-6a-502

(1) A person may not operate or be in actual physical control of a vehicle within this State if the person:

(a) has sufficient alcohol in the person's body that a subsequent chemical test shows that the person has a blood or breath alcohol concentration of .08 grams or greater at the time of the test;

(b) is under the influence of alcohol, any drug, or the combined influence of alcohol and any drug to a degree that renders the person incapable of safely operating a vehicle; or

(c) has a blood or breath alcohol concentration of .08 grams or greater at the time of operation or actual physical control.

(2) Alcohol concentration in the blood shall be based upon grams of alcohol per 100 milliliters of blood, and alcohol concentration in the breath shall be based upon grams of alcohol per 210 liters of breath.

\section{Utah Code Ann. § 41-6a-517}

Definitions-Driving with any measurable controlled substance in the body

(1) As used in this section:

a. "Controlled substance" means any substance scheduled under Section 58- 37-4.

b. "Practitioner" has the same meaning as provided in Section 58-37-2.

c. "Prescribe" has the same meaning as provided in Section 58-37-2.

d. "Prescription" has the same meaning as provided in Section 58-37-2.

(2) In cases not amounting to a violation of Section 41-6a-502, a person may not operate or be in actual physical control of a motor vehicle within this State if the person has any measurable controlled substance or metabolite of a controlled substance in the person's body. 
(3) It is an affirmative defense to prosecution under this section that the controlled substance was involuntarily ingested by the accused or prescribed by a practitioner for use by the accused.

\section{Drug Specifics}

Any controlled substance or metabolite thereof.

\section{Statutory Sanctions}

Table 35. Utah Statutory Sanctions

\begin{tabular}{|c|c|c|c|c|c|}
\hline State & $\begin{array}{l}\text { Drug Per } \\
\text { Se Law }\end{array}$ & $\begin{array}{c}\text { DRE } \\
\text { Program }\end{array}$ & Effective Date & Law & Sanctions for First Offense \\
\hline UT & Yes & Yes & May 2, 1994 & $\begin{array}{l}\text { Utah has a zero- } \\
\text { tolerance per se } \\
\text { drugged driving } \\
\text { law enacted for } \\
\text { any controlled } \\
\text { substances or } \\
\text { metabolite thereof. } \\
\text { (Utah Code } \\
\text { Section } 41-6 a- \\
502, \text { Section } 41- \\
6 a-517) \text {. } \\
\text { Involuntary or } \\
\text { prescribed use is } \\
\text { an affirmative } \\
\text { defense. }\end{array}$ & $\begin{array}{l}\text { Criminal: Not more than } 6 \text { months (48 } \\
\text { hours mandatory) imprisonment, not } \\
\text { more than } \$ 1,000 \text { ( } \$ 700 \text { mandatory) } \\
\text { fine for } 1 \text { st offense; not more than } 6 \\
\text { months (no mandatory), not more } \\
\text { than } \$ 1,000 \text { (no mandatory) for a per } \\
\text { se offense; not more than } 1 \text { year, not } \\
\text { more than } \$ 1,000 \text { for a } 1 \text { st or } 2 \text { nd } \\
\text { injury related DUl offense; not more } \\
\text { than } 5 \text { years, not more than } \$ 5,000 \\
\text { for any serious injury DUl offense } \\
\text { (felony). } \\
\text { Court-Ordered Other: The court may } \\
\text { order community service in lieu of } \\
\text { imprisonment, restitution either to a } \\
\text { victim directly or to a Victims' } \\
\text { Compensation Fund, electronic home } \\
\text { monitoring as an alternative to } \\
\text { imprisonment or community service, } \\
\text { and participation in a drug education } \\
\text { program. } \\
\text { Administrative: } 90 \text { days suspension } \\
\text { for } 1 \text { st per se offense; } 1 \text { year } \\
\text { suspension for } 2 \text { nd per se offense; } \\
180 \text { days (mandatory) suspension for } \\
1 \text { st DUI offense. All drivers must } \\
\text { complete a drug education or } \\
\text { treatment program prior to } \\
\text { reinstatement. }\end{array}$ \\
\hline
\end{tabular}

Criminal: Not more than 6 months (48 hours mandatory) imprisonment, not more than $\$ 1,000$ (\$700 mandatory) fine for first offense; not more than 6 months (240 hours mandatory), not more than $\$ 1,000$ (\$800 mandatory) for second offense within 6 years; not more than 6 months (no mandatory), not more than $\$ 1,000$ (no mandatory) for a per se offense; not more than 5 years (1,000 hours mandatory), not more than $\$ 5,000$ ( $\$ 1,500$ mandatory) for third or subsequent offense within 6 years (felony); not more than 1 year, not more than $\$ 1,000$ for a first or second injury related DUI offense; not more than 5 years, not more than $\$ 5,000$ for any serious injury DUI offense (felony). 
Court-Ordered Other: The court may order community service in lieu of imprisonment, restitution either to a victim directly or to a Victims' Compensation Fund, electronic home monitoring as an alternative to imprisonment or community service, and participation in a drug education program.

Administrative: 90 days suspension for first per se offense; 1 year suspension for second per se offense; 180 days (mandatory) suspension for first DUI offense; 2 years (mandatory) revocation for subsequent DUI offenses within 6 years. All drivers must complete a drug education or treatment program prior to reinstatement. 


\section{Implementation and Handling of Utah's DUID Cases}

An officer develops probable cause by improper driving or equipment violation in order to make the initial stop. If, in contact with the driver, the officer develops reasonable suspicion of alcohol or drug impairment, then the officer pursues further investigation.

If the driver shows physical impairment and a low BAC, or there are obvious signs of drug use (drug paraphernalia, etc.) apparent, the driver is arrested and officer gathers further information.

A DRE may be called in to do an evaluation or the arresting officer may gather additional information on his or her own.

Typically, the officer requests a blood sample from the driver and sends it to the State or local agency lab for analysis.

If drug results are positive, the officer may send them to the licensing agency, which can then administratively revoke the driver's license.

In case of refusal, the officer requests a warrant telephonically or in person from the magistrate or judge, and a sample is taken, usually at a hospital in metropolitan areas, but sometimes by an officer

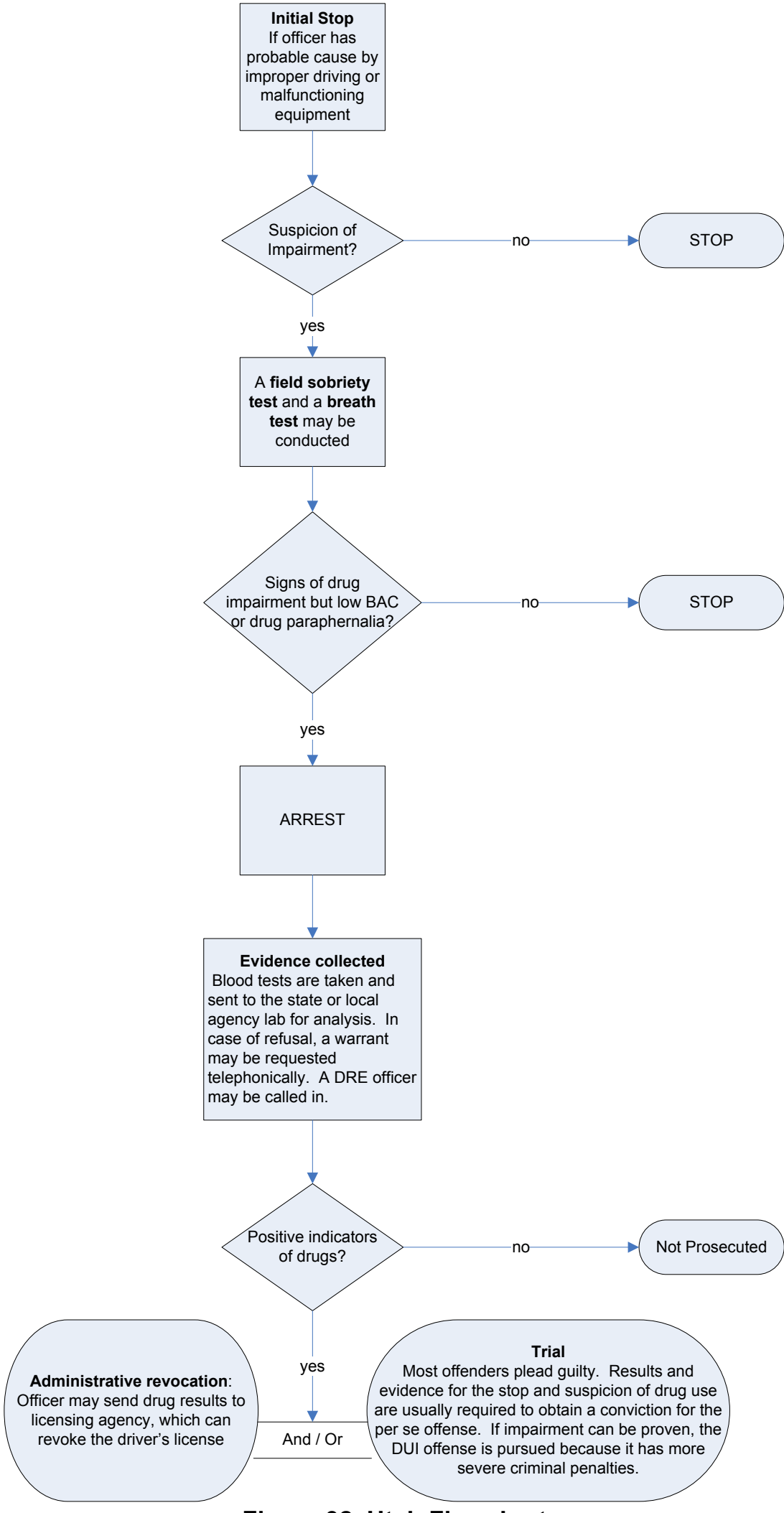

Figure 32. Utah Flowchart 
who has had phlebotomy training. Requesting warrants is a growing trend but not yet pervasive throughout the State.

Most cases are reported to be pled guilty.

At trial, the presence of the drug and evidence for the stop and suspicion of drug use are usually required to obtain a conviction for the per se offense. However, if impairment can be proven, the DUI offense is pursued because it has more severe criminal penalties.

Utah's official records do distinguish between the DUID and DUI-alcohol arrest and disposition.

\section{Data}

Data for DRE Evaluations for the State of Utah were obtained from the National DRE Database. The Utah DRE coordinator reported Utah had 204 active DRE certified officers in 2004. The IACP reported there were 115 DREs in the State at the end of 2007.

Data for DUID arrests, DUID convictions, DUID lesser offense convictions, DUI-Alcohol (DUIA) convictions, and DUI-A lesser offense convictions for the State of Utah were provided by the Utah Department of Public Safety (personal communication with Sherry Stark).

Table 36. Utah's Summary Data on DUID and DUI-A Actions

\begin{tabular}{lrrrrrr}
\hline Year & $\begin{array}{c}\text { DRE } \\
\text { Evaluations }\end{array}$ & $\begin{array}{c}\text { DUID } \\
\text { Arrests }\end{array}$ & $\begin{array}{c}\text { DUID } \\
\text { Convictions }\end{array}$ & $\begin{array}{c}\text { DUID Lesser } \\
\text { Offense } \\
\text { Convictions }\end{array}$ & $\begin{array}{c}\text { DUI-A } \\
\text { Arrests }\end{array}$ & $\begin{array}{c}\text { DUI-A } \\
\text { Convictions }\end{array}$ \\
\hline $\mathbf{2 0 0 5}$ & 295 & 1,022 & 806 & 113 & 14,330 & 8,004 \\
\hline $\mathbf{2 0 0 4}$ & 249 & 1,158 & 992 & 75 & 14,268 & 7,976 \\
\hline $\mathbf{2 0 0 3}$ & 222 & 1,043 & 886 & 67 & 14,551 & 8,503 \\
\hline $\mathbf{2 0 0 2}$ & & 1,154 & 1,012 & 80 & 14,650 & 8,512 \\
\hline $\mathbf{2 0 0 1}$ & & 1,395 & 1,186 & 138 & 16,531 & 9,179 \\
\hline $\mathbf{2 0 0 0}$ & & 922 & 775 & 95 & 15,224 & 8,320 \\
\hline $\mathbf{1 9 9 9}$ & & 708 & 584 & 83 & 14,311 & 7,967 \\
\hline
\end{tabular}

Utah's drug per se law took effect in 1994 and historical data are not available to discern any changes in DUID dispositions, which may have come about with its passage. However, examination of Table 36 shows that in recent years DUID conviction rates have averaged over $80 \%$ for the originally charged offense, which is a higher rate than observed for DUI-Alcohol (in the range of $55 \%$ to $58 \%$ ). Additionally, it appears on average, about $6.5 \%$ of impaired-driving arrests in Utah are for drugged driving. 


\section{Virginia}

\section{State with Drug Per Se Law and}

\section{DRE Activity}

\section{Summary of Virginia's Drug Per Se Law}

Virginia has a per se drugged driving law enacted for illegal controlled substances, not including cannabis or cannabis metabolites (Virginia Code 18.2-266). Included are cocaine, methamphetamine, phencyclidine and 3,4methylenedioxymethamphetamine.

Virginia law calls for a $\$ 250$ minimum fine,

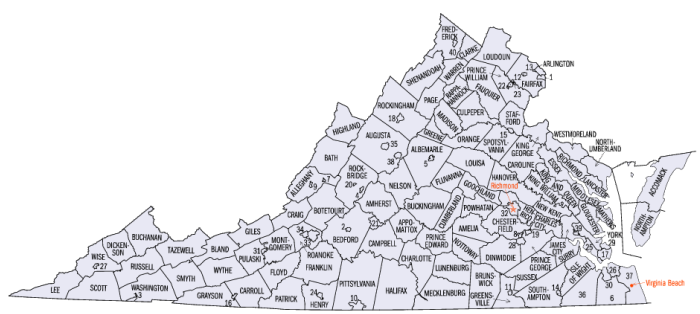

Figure 33. Virginia alcohol/drug assessment and treatment and a one-year license revocation for first offense.

\section{Effective Date}

Virginia's drug per se law took effect on July 1, 2005.

\section{Drug Per Se Law}

Va. Code Ann. $§ 18.2-266$. Driving motor vehicle, engine, etc., while intoxicated, etc.

It shall be unlawful for any person to drive or operate any motor vehicle, engine or train:

i. while such person has a blood alcohol concentration of 0.08 percent or more by weight by volume or 0.08 grams or more per 210 liters of breath as indicated by a chemical test administered as provided in this article,

ii. while such person is under the influence of alcohol,

iii. while such person is under the influence of any narcotic drug or any other selfadministered intoxicant or drug of whatsoever nature, or any combination of such drugs, to a degree which impairs his ability to drive or operate any motor vehicle, engine or train safely, iv. while such person is under the combined influence of alcohol and any drug or drugs to a degree which impairs his ability to drive or operate any motor vehicle, engine or train safely, or

v. while such person has a blood concentration of any of the following substances at a level that is equal to or greater than:

a. 0.02 milligrams of cocaine per liter of blood,

b. 0.1 milligrams of methamphetamine per liter of blood,

c. 0.01 milligrams of phencyclidine per liter of blood, or

d. 0.1 milligrams of 3,4-methylenedioxymethamphetamine per liter of blood. A charge alleging a violation of this section shall support a conviction under clauses (i), (ii), (iii), (iv), or $(v)$. 


\section{Drug Specifics}

Drugs covered include cocaine, methamphetamine, phencyclidine, and 3,4methylenedioxymethamphetamine.

\section{Statutory Sanctions}

Table 37. Virginia Statutory Sanctions

\begin{tabular}{|c|c|c|c|c|c|}
\hline State & $\begin{array}{l}\text { Drug Per } \\
\text { Se Law }\end{array}$ & $\begin{array}{c}\text { DRE } \\
\text { Program }\end{array}$ & $\begin{array}{c}\text { Effective } \\
\text { Date }\end{array}$ & Law & Sanctions for First Offense \\
\hline VA & Yes & No & $\begin{array}{l}\text { July } 1, \\
2005\end{array}$ & $\begin{array}{l}\text { Virginia has a per se drugged } \\
\text { driving law enacted for illegal } \\
\text { controlled substances, not } \\
\text { including cannabis or cannabis } \\
\text { metabolites (Virginia Code 18.2- } \\
\text { 266). Included are cocaine, } \\
\text { methamphetamine, phencyclidine } \\
\text { and } 3,4- \\
\text { methylenedioxymethamphetamine. }\end{array}$ & $\begin{array}{l}\text { Criminal: No minimum jail } \\
\text { term, but a mandatory } \\
\text { minimum fine of } \$ 250 \text { for } 1 \text { st } \\
\text { offense. } \\
\text { Court-Ordered Other: The } \\
\text { court may order participation in } \\
\text { an alcohol safety action } \\
\text { program and assessment and } \\
\text { treatment. } \\
\text { Administrative: License } \\
\text { revocation for } 1 \text { year for } 1 \text { st } \\
\text { offense; } 3 \text { years for second } \\
\text { offense, and three years for } \\
\text { third or subsequent offense. }\end{array}$ \\
\hline
\end{tabular}

Criminal: No minimum jail term, but a mandatory minimum fine of $\$ 250$ for first offense; a mandatory minimum fine of $\$ 500$ and 1 month imprisonment (with 10 days mandatory) for second offense within 5 to 10 years; mandatory minimum of six months and $\$ 1,000$ fine for third offense within five years; for third offense within 10 years mandatory minimum imprisonment of 90 days and $\$ 1,000$. Mandatory minimum of one year imprisonment and $\$ 1,000$ for fourth or subsequent offense.

Court-Ordered Other: The court may order participation in an alcohol safety action program and assessment and treatment.

Administrative: License revocation for 1 year for first offense; 3 years for second offense, and three years for third or subsequent offense. 


\section{Implementation and Handling of Virginia's DUID Cases}

An officer may make a stop based on reasonable suspicion (weaving within the lane, wide turns, slower than normal speeds, etc.) and/or probably cause if a violation of Virginia code is observed (equipment violation, speeding, failure to dim lights, etc.).

Investigation into impairment may lead to probable cause for arrest.

A DRE may be called in to assist with an evaluation or the arresting officer may gather additional information.

Typically, the officer requests a blood sample from the driver and sends it to the State lab for analysis.

In case of refusal, an additional charge is placed against the operator, and if convicted will result in the suspension of his/her driver's license.

If drug results are positive, the officer may send them to the licensing agency, which can then administratively revoke the driver's license.

At trial, reason for the stop and evidence of impairment are required to obtain a conviction.

Virginia's official records do not readily distinguish between the DUID and DWIalcohol arrest and disposition.

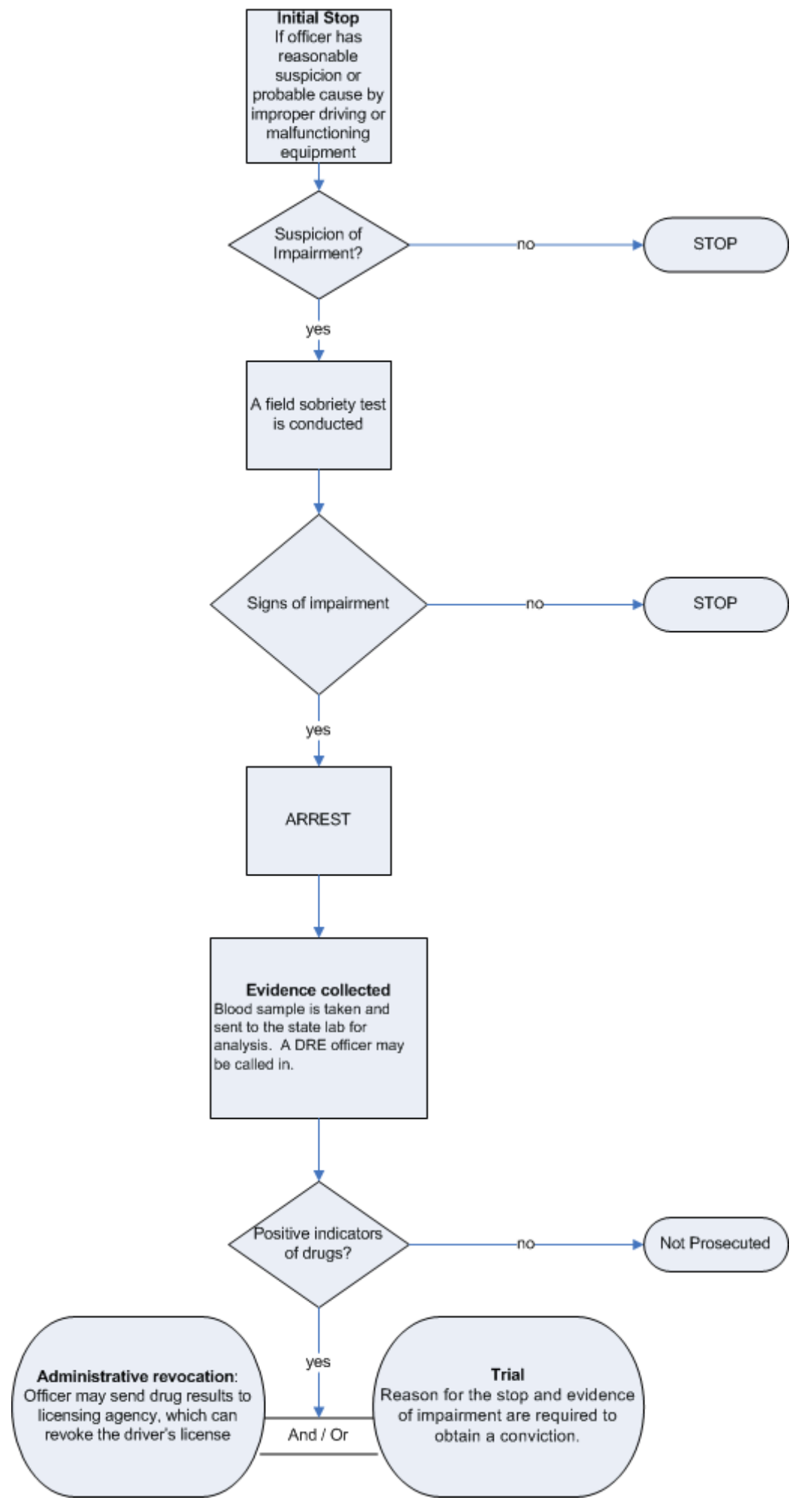

Figure 34. Virginia Flowchart 


\section{Data}

Virginia's DRE coordinator reported there were two active DRE certified officers in Virginia in 2004. DUI-Alcohol (DWI-A) arrest data was obtained from the FBI Arrest Statistics.

Table 38. Virginia's Summary Data on DUID and DWI Actions

\begin{tabular}{|c|c|c|c|c|c|}
\hline Year & $\begin{array}{c}\text { DRE } \\
\text { Evaluations* }\end{array}$ & $\begin{array}{c}\text { DUID } \\
\text { Arrests* }\end{array}$ & $\begin{array}{c}\text { DUID } \\
\text { Convictions* }\end{array}$ & $\begin{array}{c}\text { DUID Lesser } \\
\text { Offense } \\
\text { Convictions* }\end{array}$ & $\begin{array}{r}\text { DWI-A } \\
\text { Arrests } \\
\end{array}$ \\
\hline \multicolumn{6}{|l|}{$2005^{\star *}$} \\
\hline 2004 & & & & & 25,920 \\
\hline 2003 & & & & & 25,101 \\
\hline
\end{tabular}

Data are not yet available to assess the potential effects of Virginia's drug per se law. 


\section{Conclusions and Recommendations}

This study was an attempt to develop an understanding of the effects of adopting and implementing drug per se laws for impaired driving. Though State officials, law enforcement officers, and prosecutors were all very helpful in describing the implementation of these laws, it was difficult to obtain objective data on the volume of DUID cases arrested and adjudicated before and after adoption of the laws. This makes it difficult to objectively assess whether the law changed patterns of arrests and conviction for drug-impaired driving. However, fragmentary data were available from a few States.

The general perspective of officials contacted in the impaired-driving control system in the several States we studied was that adopting a drug per se provision was a positive move for traffic safety. People in States with DRE programs were supportive of having that capability, and in some instances, prosecutors had a perception that having a DRE officer made it more likely to obtain a guilty plea. However, whether with or without a DRE, prosecutors generally felt DUID cases had very high conviction rates with very few cases actually going to trial. It is clear, however, that even in States with large and active DRE programs, because there are a limited number of DRE officers relative to the volume of potential drugged driving cases, the vast majority of these cases are investigated and taken through the evidential and adjudicative process by the initial arresting officer, reportedly in a generally successful manner. This is not an indictment of the DRE program, but rather an observation that with the growing sensitivity to drugged driving cases, patrol officers have been forced to and have been successful in investigating a number of "routine" drugged driving cases on their own.

One frustration of this study was the paucity of objective data to bolster the perceptions reported above. Because the DUID offense (per se or not) is typically a component of the basic impaireddriving offense, most data systems have not been structured to separately identify DUID cases, whether within arrest records, court records, or motor vehicle department records. Additionally, many people who are charged with DUID also have alcohol in their system and may potentially be convicted based on the alcohol evidence alone, the drug evidence alone, or the combination thereof. Court and motor vehicle record systems do not tend to record the rationale for a conviction, but rather the fact of the conviction itself. In all likelihood, most court records systems would encounter a problem making this type of distinction.

That is not to say, however, that record systems should not be improved to permit gaining additional knowledge about the volume and disposition patterns of DUID offenses. For example, at the level of arrest, it should be possible for police agencies to identify whether it was the suspicion of alcohol, other drugs, or the combination thereof, which triggered the arrest decision. In fact, much of this type of information is currently collected during the arrest process. Some of it is in narrative form, but many aspects are recorded through checkboxes and the like. With the ever more widespread adoption of electronic reporting of arrest and crash information by officers, it is important these sorts of issues be kept in mind and that the data systems capture this level of detail. Similarly, court records systems are also becoming more computerized and steps to integrate a whole case from arrest through disposition and sanctioning are being taken. It is important to the understanding of issues such as the ones addressed in this study that the data systems be designed to not only track single cases, but also to be able to summarize data across a whole spectrum of cases, such as impaired driving. 
It is recommended States develop procedures where citations indicate not only drugs, alcohol, or both, but also adopt procedures that ensure information is integrated into computerized data systems of arresting agencies, courts, and motor vehicles departments.

This study was initially intended to be one of the effectiveness of the adoption of drug per se laws as a countermeasure against drug-impaired driving. The issues discussed above highlight the difficulty in accomplishing this objective. Information from the few States where some data on drug-impaired driving and arrests were available and information gleaned from practitioners in different areas or the traffic law system, indicate drug per se laws show promise in generating more drug-related impaired-driving arrests and may help insure conviction and sanctioning where appropriate. However, more complete and accurate data will be necessary to more conclusively answer this question. 


\section{References}

Borkenstein, R. F., Crowther, R. F., Shumante, R. P., Ziel, W. B., \& Zylman, R. (1964). The role of the drinking driver in traffic accidents. Bloomington, IN: Department of Police Administration, Indiana University.

Compton, R. (1986). Field evaluation of the Los Angeles police department drug detection program. DOT HS 807 012. Washington, DC: National Highway Traffic Safety Administration.

Compton, R. P., \& Anderson, T. E. (1985). The incidence of driving under the influence of drugs 1985: An update of the state of knowledge. Staff Technical Report. DOT HS 806900. Washington, DC: National Highway Traffic Safety Administration.

Dussault, C., Lemire, A. M., Bouchard, J., \& Brault, M. (2000). Drug use among Quebec drivers: The 1999 roadside survey. In H. Laurell \& F. Schlyter (Eds.), Alcohol, Drugs and Traffic Safety - T 2000: Proceedings of the 15th International Conference on Alcohol, Drugs and Traffic Safety, May 22-26, 2000. Stockholm, Sweden: ICADTS.

Hersch, R. K., Crouch, D. J., \& Cook, R. F. (2000). Field test of on-site drug detection devices DOT HS 809 192. Washington, DC: National Highway Traffic Safety Administration.

Holcomb, R. L. (1938). Alcohol in relation to traffic accidents. Journal of the American Medical Association, 111, 1076-1085.

Mathijssen, M. P., Movig, K. L., de Gier, J. J., Nagel, P. H., van Egmond, T., \& Egberts, A. C. (2002). Use of psychoactive medicines and drugs as a cause of road trauma. In D. R. Mayhew \& C. Dussault (Eds.), Proceedings of Alcohol, Drugs \& Traffic Safety - T 2002: 16th International Conference on Alcohol, Drugs \& Traffic Safety, August 4-9, 2002 (Vol. 2, pp. 451-457). Montreal, Canada: ICADTS.

Moskowitz, H. (2006). Commentary on Variability among Epidemiological Studies of Drugs and Driving. Transportation Research Circular No. E-C096: Drugs and Traffic: A Symposium, June 20-21, 2005. Woods Hole, MA, Transportation Research Board of the National Academies: 36-40.

Peck, R. C. (1987). An evaluation of the California drunk driving countermeasure system: An overview of study findings and policy implications. In R. C. Peck (Ed.), California Department of Motor Vehicles Research Studies: A summary of findings and conclusions. Sacramento, CA: California Department of Motor Vehicles.

Preusser, D. F., Ulmer, R. G., \& Preusser, C. W. (1992). Evaluation of the impact of the drug evaluation and classification system on enforcement and adjudication. Final Report. DOT HS 808 058. Washington, DC: National Highway Traffic Safety Administration.

State of Illinois. (May 2008) 2008 Illinois DUI Fact Book. Accessed online at: http://www.duiillinois-attorney.com/CM/Articles/2008_Illinois_DUI_Fact_Book.pdf

Terhune, K. W., Ippolito, C. A., Hendricks, D. L., Michalovic, J. G., Bogema, S. C., Santinga, P., Blomberg, R., \& Preusser, D. F. (1992). The incidence and role of drugs in fatally injured drivers. DOT HS 808 065. Washington, DC: National Highway Traffic Safety Administration. 
Tippetts, A. S., Voas, R. B., Fell, J. C., \& Nichols, J. L. (2005). A meta-analysis of .08 BAC laws in 19 jurisdictions in the United States. Accident Analysis and Prevention, 37(1), 149-161.

Walsh, J., De Gier, J., Christopherson, A., \& Verstraete, A. (2004). Drugs and driving. Traffic Injury Prevention, 5, 241-253.

Walsh, J. M., Danziger, G., Cangianelli, L., \& Koehler, D. B. (2002, November). Driving under the influence of drugs [DUID] legislation in the United States: Report to Robert Woods Johnson Foundation under Grant \#040023. Bethesda, Maryland: The Walsh Group. 


\section{Appendix A}

\section{Questions for Structured Discussions with Prosecutors and Judges}

\section{Please get prosecutor's name, affiliation, phone number.}

\section{Be sure to give ground rules on speaking their mind, anonymity, and if you are recording} the conversation. Do not lead questions or insert opinions.

INTRO: We are conducting a study for NHTSA that focuses on DUI and DUID laws. We want to get your perspective on the law and your experience in implementing the law from the prosecutorial perspective.

(If the person has met with John Lacey already...) I know you met with John Lacey and answered his questions when he was in (State) in (Date) . He's asked me to call you to ask a few more questions about drug per se in your state. Some of these questions you've probably already answered with John, but I'm asking each person he interviewed the same set of questions to clarify and summarize responses. In addition, I'm not as familiar with the drug per se area, so please excuse my ignorance.

The first question is...

1. How frequently do you prosecute DUID cases?

2. Are there special issues related to those cases?

3. Do they seem to be more likely to be contested than alcohol-based results?

4. Is it more difficult to develop probable cause than alcohol-based results?

5. What are the typical prosecution witnesses you need?

6. Do you get test results in a timely enough manner?

a. What types of test results are necessary to obtain a conviction?

7. Is a drug recognition expert (DRE) required to make a case?

8. Are there any special court rulings we should be aware of?

9. If there is a BAC above .08 do you pursue the drug case?

a. Are charges being filed for both alcohol and drug impairment against the same offender? If not, why aren't both charges being filed?

10. Do you sometimes deal the DUID case for a possession or a distribution plea?

11. Are DUID cases more or less likely to plead that regular DUI cases?

12. Are there administrative sanctions for DUID as there are for alcohol? 
13. Does a drugged driving offense result in an enhanced sanction over alcohol offense, i.e., is the sanction more severe? In addition, if you have alcohol and drugs, is the sanction more severe?

14. Have there been changes over time the pattern of dispositions for DUID cases?

15. Since the per se law, do you think DUID are increasing, decreasing, or staying about the same over time?

16. How do you view the DUID offense? (Is it a per se offense like for alcohol?)

a. If per se route, when did the law go into effect?

17. Did the per se law result in changes in procedures and conviction patterns?

18. What is the general attitude of the courts towards the DUID law?

19. Do you feel the conviction rates for DUID have changed over time?

a. What changes have occurred?

20. About what proportion of DUID cases result in trial? (jury trials)

a. Is that different from DUI cases?

21. Has the change in the law to DUID per se resulted in changes in the way you prosecute the offense?
a. Different witnesses needed?
b. Different documentation of test results?
c. Reduced need to prove impairment?
d. Different perspective on the offense from judges?

22. Is it any easier to obtain a conviction?

23. Are there any new lesser included offenses?

24. In your records, do you distinguish between DUID cases and DUI-alcohol cases? Can you provide us with data on DUID cases and dispositions over time? Who is the custodian of these data?

25. Does the statute distinguish between DUID and DUI-alcohol?

\section{General Questions}

26. What are your feelings regarding the DEC (Drug Evaluation \& Classification) Program?
a. Do you believe that the DEC program is effective?
b. Do you think the State government supports the DEC program?
c. Do you think the DEC program plays an important role in dealing with drugged driving in this State?


27. Have there been recent changes...
a. With regard to the number of arrests/cases filed/adjudication results?
b. The public awareness of the per se laws among licensed drivers in this State?
c. Impact on traffic safety [i.e., fewer crashes, etc.]?
d. Opinion of police officers about looking for Drugged Drivers?

28. Do you believe that the general public is aware of the DUID legislation?

29. Do you believe that most police officers are aware of the DUID legislation?

30. What do you believe is the general attitude in your state towards DUID? (In comparison to DUI?)

Be sure that you:

Gain understanding of how the process works

Detect any problems the drug per se laws may have created

Identify solutions

Get a clear picture of prosecutor's understanding of what is needed to make an arrest under a drugged driving law, and if it is different in a drug per se law State

Identify data sources and contracts on arrests and dispositions of DUID cases 


\section{Questions for Structured Discussions with Law Enforcement}

\section{Please have officers sign in on a Roster of Attendees with name, affiliation, phone number.}

Put name tents on the table.

INTRO:

A. Moderator welcomes participants and introduces self. Explain what PIRE is.

B. Explain the study and the purpose of the group discussion (e.g., We are conducting a study for NHTSA that focuses on DUI and DUID laws. We want to get your perspective on the law and your experience implementing the law from stop through dispositions.

C. We're going to talk for an hour and a half. Please turn off cell phones.

D. We are interested in your opinions. There are no right or wrong answers. Please be open and honest. We are sincerely interested in learning what you think.

E. Information we collect will be summarized only for this project. What you say will be kept totally private. We will not use any names or quote anyone by name. So that we can remember what you said and not miss anything, I'd like to turn on this recorder. If you want to say something off the record, just let me know and I'll turn off the recorder.

\section{GROUND RULES FOR GROUP DISCUSSION:}

A. This will be an informal discussion.

B. We will talk for 1 and $1 / 2$ hours. There will be no formal breaks, but please feel free to get up at any time to stretch, go to the bathroom (provide location), or get something to eat or drink (indicate table with refreshments).

C. We would like only one person to talk at a time. It's very important so that we can get a clear recording. If more than one person starts talking at one time, I will need to ask you to take turns so we can hear everyone. We hope that each of you will speak up, and tell us your thoughts and feelings, even if they are different from what others have said. We are interested in both negative and positive comments.

D. We appreciate your input very much.

E. Any questions? (Pause)

\section{(Pause) TURN ON RECORDER}

\section{Icebreaker}

This first question helps highlight the common characteristics of the participants and that they all have some basis for sharing information.

You all probably know each other, but I don't. Let's start by going around the room. Say your first name only, and what your current assignment is. 


\section{Be sure to give ground rules on speaking their mind, anonymity, and recording the conversation.}

31. Please describe how a typical DUID case develops from stop through disposition.

32. How is initial suspicion of DUID typically developed? (Drugs, paraphernalia, low BAC?)

33. Must a DRE officer be called in?

a. At what point is the DRE called in?

b. Are there many cases that rely just on the regular patrol officer's judgment, where he or she just does it all by him or herself?

34. What biological samples are taken? (urine, blood, oral fluid, breath)

a. Who chooses?

b. Are there problems obtaining those samples? And transporting them?

c. Is there a set sequence for which samples are requested? (blood first? Injury cases different?)

d. Where are samples sent for analysis?

e. Do you receive results back? How long does it take to get these results?

f. Does that pose a problem for the courts and/or DMV?

g. When you do get results, do you need expert witnesses in court?

35. Do you use screening tests? If so, what kind?

36. What typically happens if the BAC exceeds .08? (Does the DUID case continue to be prosecuted/pursued?)

37. Are you more likely to have to appear in court for DUID than for a regular DUI?

a. Describe how the testimony goes.

b. Does the DUID case sometimes require more testimony from other persons as well, like the toxicologist, etc?

38. Do DUID arrests sometime result in possession or distribution charges?

a. Which takes precedence?

39. Do you find out about the disposition of DUID cases and is that different from regular DUI cases?

40. Are there administrative sanctions for DUID as there are for alcohol?

41. Is your command staff supportive of DUI and DUID enforcement?

a. What about other officers?

42. How do you view the DUID offense?

a. Is it a per se offense like for alcohol? 
b. Once it is established that it is a per se State, query about whether the change to per se status affected how they enforce drugged driving.

43. Has the volume of DUID arrests changed over time? And how?

44. In your jurisdiction, are separate records kept on DUI and DUID? We're having trouble finding this data in (this State) - do you have any idea where we might find it?

Be sure that you:

Gain understanding of how the process works

Detect any problems the drug per se laws may have created

Identify solutions

Get a clear picture of peoples' understanding of what is needed to make an arrest under a drugged driving law, and if it is different from a non-per se State, and different from a DUI arrest.

Identify data sources and contracts on arrests and dispositions of DUID cases, if possible 


\section{Appendix B: Drug Specifics}

\section{Arizona}

\section{Drug Specifics}

Any drug, any substance containing a toxic substance, or any drug (or its metabolite) defined in Section 13-3401.

1. "Amidone" means any substance identified chemically as (4-4-diphenyl-6-dimethylamineheptanone-3), or any salt of such substance, by whatever trade name designated.

2. "Cannabis" means the following substances under whatever names they may be designated:

(a) The resin extracted from any part of a plant of the genus cannabis, and every compound, manufacture, salt, derivative, mixture or preparation of such plant, its seeds or its resin. Cannabis does not include oil or cake made from the seeds of such plant, any fiber, compound, manufacture, salt, derivative, mixture or preparation of the mature stalks of such plant except the resin extracted from the stalks or any fiber, oil or cake or the sterilized seed of such plant which is incapable of germination.

(b) Every compound, manufacture, salt, derivative, mixture or preparation of such resin or tetrahydrocannabinol.

3. "Coca leaves" means cocaine, its optical isomers and any compound, manufacture, salt, derivative, mixture or preparation of coca leaves, except derivatives of coca leaves which do not contain cocaine, ecgonine or substances from which cocaine or ecgonine may be synthesized or made.

3. "Dangerous drug" means the following by whatever official, common, usual, chemical or trade name designated:

(a) Any material, compound, mixture or preparation which contains any quantity of the following hallucinogenic substances and their salts, isomers and salts of isomers, unless specifically excepted, whenever the existence of such salts, isomers and salts of isomers is possible within the specific chemical designation:

(i) Alpha-ethyltryptamine.

(ii) Aminorex.

(iii) 4-bromo-2, 5-dimethoxyphenethylamine.

(iv) 4-bromo-2, 5-dimethoxyamphetamine.

(v) Bufotenine.

(vi) Diethyltryptamine.

(vii) 2, 5-dimethoxyamphetamine.

(viii) Dimethyltryptamine.

(ix) 5-methoxy-3, 4-methylenedioxyamphetamine.

(x) 4-methyl-2, 5-dimethoxyamphetamine.

(xi) Ibogaine.

(xii) Lysergic acid amide.

(xiii) Lysergic acid diethylamide.

(xiv) Mescaline.

(xv) 4-methoxyamphetamine.

(xvi) Methoxymethylenedioxyamphetamine (MMDA).

(xvii) Methylenedioxyamphetamine (MDA).

(xviii) 3, 4-methylenedioxymethamphetamine. 
(xix) 3, 4-methylenedioxy-N-ethylamphetamine.

(xx) N-ethyl-3-piperidyl benzilate (JB-318).

(xxi) N-hydroxy-3, 4-methylenedioxyamphetamine.

(xxii) N-methyl-3-piperidyl benzilate (JB-336).

(xxiii) N-(1-phenylcyclohexyl) ethylamine (PCE).

(xxiv) Nabilone.

(xxv) 1-(1-phenylcyclohexyl) pyrrolidine (PHP).

(xxvi) 1-(1-(2-thienyl)-cyclohexyl) piperidine (TCP).

(xxvii) 1-(1-(2-thienyl)-cyclohexyl) pyrrolidine.

(xxviii) Para-methoxyamphetamine (PMA).

(xxix) Psilocybin.

(xxx) Psilocyn.

(xxxi) Synhexyl.

(xxxii) Trimethoxyamphetamine (TMA).

(b) Any material, compound, mixture or preparation which contains any quantity of the following substances and their salts, optical isomers, and salts of optical isomers having a potential for abuse associated with a stimulant effect on the central nervous system:

(i) Amphetamine.

(ii) Benzphetamine.

(iii) Butorphanol.

(iv) Cathine ((+)-norpseudoephedrine).

(v) Chlorphentermine.

(vi) Clortermine.

(vii) Diethylpropion.

(viii) Fencamfamin.

(ix) Fenethylline.

(x) Fenproporex.

(xi) Mazindol.

(xii) Mefenorex.

(xiii) Methamphetamine.

(xiv) Methcathinone.

(xv) 4-methylaminorex.

(xvi) Methylphenidate.

(xvii) Modafinil.

(xviii) N-ethylamphetamine.

(xix) N, N-dimethylamphetamine.

(xx) Pemoline.

(xxi) Phendimetrazine.

(xxii) Phenmetrazine.

(xxiii) Phentermine.

(xxiv) Pipradol.

(xxv) Propylhexedrine.

(xxvi) Pyrovalerone.

(xxvii) Sibutramine.

(xxviii) Spa ((-)-1-dimethylamino-1,2-diphenylethane). 
(c) Any material, compound, mixture or preparation which contains any quantity of the following substances having a potential for abuse associated with a depressant effect on the central nervous system:

(i) Any substance which contains any quantity of a derivative of barbituric acid, or any salt of a derivative of barbituric acid, unless specifically excepted.

(ii) Alprazolam.

(iii) Bromazepam.

(iv) Camazepam.

(v) Carisoprodol.

(vi) Chloral betaine.

(vii) Chloral hydrate.

(viii) Chlordiazepoxide.

(ix) Chlorhexadol.

(x) Clobazam.

(xi) Clonazepam.

(xii) Clorazepate.

(xiii) Clotiazepam.

(xiv) Cloxazolam.

(xv) Delorazepam.

(xvi) Diazepam.

(xvii) Dichloralphenazone.

(xviii) Estazolam.

(xix) Ethchlorvynol.

(xx) Ethinamate.

(xxi) Ethyl loflazepate.

(xxii) Fenfluramine.

(xxiii) Fludiazepam.

(xxiv) Flunitrazepam.

(xxv) Flurazepam.

(xxvi) Gamma hydroxy butyrate.

(xxvii) Glutethimide.

(xxviii) Halazepam.

(xxix) Haloxazolam.

(xxx) Ketamine.

(xxxi) Ketazolam.

(xxxii) Loprazolam.

(xxxiii) Lorazepam.

(xxxiv) Lormetazepam.

(xxxv) Lysergic acid.

(xxxvi) Mebutamate.

(xxxvii) Mecloqualone.

(xxxviii) Medazepam.

(xxxix) Meprobamate.

(xl) Methaqualone.

(xli) Methohexital.

(xlii) Methyprylon. 
(xliii) Midazolam.

(xliv) Nimetazepam.

(xlv) Nitrazepam.

(xlvi) Nordiazepam.

(xlvii) Oxazepam.

(xlviii) Oxazolam.

(xlix) Paraldehyde.

(l) Petrichloral.

(li) Phencyclidine.

(lii) Pinazepam.

(liii) Prazepam.

(liv) Scopolamine.

(lv) Sulfondiethylmethane.

(lvi) Sulfonethylmethane.

(lvii) Sulfonmethane.

(lviii) Quazepam.

(lix) Temazepam.

(lx) Tetrazepam.

(lxi) Tiletamine.

(lxii) Triazolam.

(lxiii) Zaleplon.

(lxiv) Zolazepam.

(lxv) Zolpidem.

(d) Any material, compound, mixture or preparation which contains any quantity of the following anabolic steroids and their salts, isomers or esters:

(i) Boldenone.

(ii) Clostebol (4-chlorotestosterone).

(iii) Dehydrochloromethyltestosterone.

(iv) Drostanolone.

(v) Ethylestrenol.

(vi) Fluoxymesterone.

(vii) Formebulone (formebolone).

(viii) Mesterolone.

(ix) Methandriol.

(x) Methandrostenolone (methandienone).

(xi) Methenolone.

(xii) Methyltestosterone.

(xiii) Mibolerone.

(xiv) Nandrolone.

(xv) Norethandrolon.

(xvi) Oxandrolone.

(xvii) Oxymesterone.

(xviii) Oxymetholone.

(xix) Stanolone (4-dihydrotestosterone).

(xx) Stanozolol.

(xxi) Testolactone. 
(xxii) Testosterone.

(xxiii) Trenbolone.

4. "Isoamidone" means any substance identified chemically as (4-4-diphenyl-5-methyl6-dimethylaminohexanone-3), or any salt of such substance, by whatever trade name designated.

5. "Isonipecaine" means any substance identified chemically as (1-methyl-4-phenylpiperidine-4-carboxylic acid ethyl ester), or any salt of such substance, by whatever trade name designated.

6. "Ketobemidone" means any substance identified chemically as (4-(3hydroxyphenyl)-1-methyl-4-piperidylethyl ketone hydrochloride), or any salt of such substance, by whatever trade name designated.

7. "Marijuana" means all parts of any plant of the genus cannabis, from which the resin has not been extracted, whether growing or not, and the seeds of such plant. Marijuana does not include the mature stalks of such plant or the sterilized seed of such plant which is incapable of germination.

8. "Narcotic drugs" means the following, whether of natural or synthetic origin and any substance neither chemically nor physically distinguishable from them:

(a) Acetyl-alpha-methylfentanyl.

(b) Acetylmethadol.

(c) Alfentanil.

(d) Allylprodine.

(e) Alphacetylmethadol.

(f) Alphameprodine.

(g) Alphamethadol.

(h) Alpha-methylfentanyl.

(i) Alpha-methylthiofentanyl.

(j) Alphaprodine.

(k) Amidone (methadone).

(l) Anileridine.

(m) Benzethidine.

(n) Benzylfentanyl.

(o) Betacetylmethadol.

(p) Beta-hydroxyfentanyl.

(q) Beta-hydroxy-3-methylfentanyl.

(r) Betameprodine.

(s) Betamethadol.

(t) Betaprodine.

(u) Bezitramide.

(v) Buprenorphine and its salts.

(w) Cannabis.

(x) Carfentanil.

(y) Clonitazene.

(z) Coca leaves.

(aa) Dextromoramide.

(bb) Dextropropoxyphene.

(cc) Diampromide. 
(dd) Diethylthiambutene.

(ee) Difenoxin.

(ff) Dihydrocodeine.

(gg) Dimenoxadol.

(hh) Dimepheptanol.

(ii) Dimethylthiambutene.

(ji) Dioxaphetyl butyrate.

(kk) Diphenoxylate.

(11) Dipipanone.

(mm) Ethylmethylthiambutene.

(nn) Etonitazene.

(oo) Etoxeridine.

(pp) Fentanyl.

(qq) Furethidine.

(rr) Hydroxypethidine.

(ss) Isoamidone (isomethadone).

(tt) Pethidine (meperidine).

(uu) Ketobemidone.

(vv) Levomethorphan.

(ww) Levomoramide.

(xx) Levophenacylmorphan.

(yy) Levorphanol.

(zz) Metazocine.

(aaa) 3-methylfentanyl.

(bbb) 1-methyl-4-phenyl-4-propionoxypiperidine (MPPP).

(ccc) 3-methylthiofentanyl.

(ddd) Morpheridine.

(eee) Noracymethadol.

(fff) Norlevorphanol.

(ggg) Normethadone.

(hhh) Norpipanone.

(iii) Opium.

(jjj) Para-fluorofentanyl.

(kkk) Pentazocine.

(111) Phenadoxone.

(mmm) Phenampromide.

(nnn) Phenazocine.

(ooo) 1-(2-phenethyl)-4-phenyl-4-acetoxypiperidine (PEPAP).

(ppp) Phenomorphan.

(qqq) Phenoperidine.

(rrr) Piminodine.

(sss) Piritramide.

(ttt) Proheptazine.

(uuu) Properidine.

(vvv) Propiram.

(www) Racemethorphan. 
(xxx) Racemoramide.

(yyy) Racemorphan.

(zzz) Remifentanil.

(aaaa) Sufentanil.

(bbbb) Thenylfentanyl.

(cccc) Thiofentanyl.

(dddd) Tilidine.

(eeee) Trimeperidine.

9. "Opium" means any compound, manufacture, salt, isomer, salt of isomer, derivative, mixture or preparation of the following, but does not include apomorphine or any of its salts:

(a) Acetorphine.

(b) Acetyldihydrocodeine.

(c) Benzylmorphine.

(d) Codeine.

(e) Codeine methylbromide.

(f) Codeine-N-oxide.

(g) Cyprenorphine.

(h) Desomorphine.

(i) Dihydromorphine.

(j) Drotebanol.

(k) Ethylmorphine.

(l) Etorphine.

(m) Heroin.

(n) Hydrocodone.

(o) Hydromorphinol.

(p) Hydromorphone.

(q) Levo-alphacetylmethadol.

(r) Methyldesorphine.

(s) Methyldihydromorphine.

(t) Metopon.

(u) Morphine.

(v) Morphine methylbromide.

(w) Morphine methylsulfonate.

(x) Morphine-N-oxide.

(y) Myrophine.

(z) Nalorphine.

(aa) Nicocodeine.

(bb) Nicomorphine.

(cc) Normorphine.

(dd) Oxycodone.

(ee) Oxymorphone.

(ff) Pholcodine.

(gg) Thebacon.

(hh) Thebaine. 
10. "Ordinary ephedrine, pseudoephedrine, (-)-norpseudoephedrine or phenylpropanolamine product" means a product that contains ephedrine, pseudoephedrine, (-)-norpseudoephedrine or phenylpropanolamine and that is all of the following:

(a) Approved for sale under the federal act.

(b) Labeled, advertised and marketed only for an indication that is approved by the federal food and drug administration.

(c) Either:

(i) A nonliquid that is sold in package sizes of not more than three grams of ephedrine, pseudoephedrine, (-)-norpseudoephedrine or phenlypropanolamine and that is packaged in blister packs containing not more than two dosage units or, if the use of blister packs is technically infeasible, that is packaged in unit dose packets or pouches.

(ii) A liquid that is sold in package sizes of not more than three grams of ephedrine, pseudoephedrine, (-)-norpseudoephedrine or phenylpropanolamine.

11. "Peyote" means any part of a plant of the genus lophophora, known as the mescal button.

12. "Precursor chemical I" means any material, compound, mixture or preparation which contains any quantity of the following substances and their salts, optical isomers or salts of optical isomers:

(a) $\mathrm{N}$-acetylanthranilic acid.

(b) Anthranilic acid.

(c) Ephedrine.

(d) Ergotamine.

(e) Isosafrole.

(f) Lysergic acid.

(g) Methylamine.

(h) N-ethylephedrine.

(i) N-ethylpseudoephedrine.

(j) N-methylephedrine.

(k) N-methylpseudoephedrine.

(l) Norephedrine.

(m) (-)-Norpseudoephedrine.

(n) Phenylacetic acid.

(o) Phenylpropanolamine.

(p) Piperidine.

(q) Pseudoephedrine.

27. "Precursor chemical II" means any material, compound, mixture or preparation which contains any quantity of the following substances and their salts, optical isomers or salts of optical isomers:

(a) 4-cyano-2-dimethylamino-4, 4-diphenyl butane.

(b) 4-cyano-1-methyl-4-phenylpiperidine.

(c) Chlorephedrine.

(d) Chlorpseudoephedrine.

(e) Ethyl-4-phenylpiperidine-4-carboxylate.

(f) 2-methyl-3-morpholino-1, 1-diphenylpropane-carboxylic acid. 
(g) 1-methyl-4-phenylpiperidine-4-carboxylic acid.

(h) N-formyl amphetamine.

(i) N-formyl methamphetamine.

(j) Phenyl-2-propanone.

(k) 1-piperidinocyclohexane carbonitrile.

(1) 1-pyrrolidinocyclohexane carbonitrile.

28. "Prescription-only drug" does not include a dangerous drug or narcotic drug but means:

(a) Any drug which because of its toxicity or other potentiality for harmful effect, or the method of its use, or the collateral measures necessary to its use, is not generally recognized among experts, qualified by scientific training and experience to evaluate its safety and efficacy, as safe for use except by or under the supervision of a medical practitioner.

(b) Any drug that is limited by an approved new drug application under the federal act or section 32-1962 to use under the supervision of a medical practitioner.

(c) Every potentially harmful drug, the labeling of which does not bear or contain full and adequate directions for use by the consumer.

(d) Any drug required by the federal act to bear on its label the legend "Caution:

Federal law prohibits dispensing without prescription" or "RX only".

29. "Produce" means grow, plant, cultivate, harvest, dry, process or prepare for sale.

30. "Regulated chemical" means the following substances in bulk form that are not a useful part of an otherwise lawful product:

(a) Acetic anhydride.

(b) Hypophosphorous acid.

(c) Iodine.

(d) Sodium acetate.

(e) Red phosphorus.

(f) Gamma butyrolactone (GBL).

(g) 1, 4-butanediol.

(h) Butyrolactone.

(i) 1, 2 butanolide.

(j) 2-oxanalone.

(k) Tetrahydro-2-furanone.

(l) Dihydro-2(3H)-furanone.

(m) Tetramethylene glycol.

31. "Vapor-releasing substance containing a toxic substance" means paint or varnish dispensed by the use of aerosol spray, or any glue, which releases vapors or fumes containing acetone, volatile acetates, benzene, butyl alcohol, ethyl alcohol, ethylene dichloride, isopropyl alcohol, methyl alcohol, methyl ethyl ketone, pentachlorophenol, petroleum ether, toluene, volatile ketones, isophorone, chloroform, methylene chloride, mesityl oxide, xylene, cumene, ethylbenzene, trichloroethylene, methyl isobutyl ketone (mibk), methyl isoamyl ketone (miak), methyl ethyl ketone (mek) or diacetone alcohol or isobutyl nitrite. 


\section{Michigan}

\section{Drug Specifics}

CHAPTER 333 HEALTH

PUBLIC HEALTH CODE

ARTICLE 7. CONTROLLED SUBSTANCES

PART 72. STANDARDS AND SCHEDULES

MCLS $\S 333.7212(2008)$

MCL $\S 333.7212$

$\S$ 333.7212. Schedule 1; controlled substances included.

Sec. 7212. (1) The following controlled substances are included in schedule 1:

(a) Any of the following opiates, including their isomers, esters, the ethers, salts, and salts of isomers, esters, and ethers, unless specifically excepted, when the existence of these isomers, esters, ethers, and salts is possible within the specific chemical designation:

Acetylmethadol Difenoxin Noracymethadol

Allylprodine Dimenoxadol Norlevorphanol

Alpha-acetylmethadol Dimepheptanol Normethadone

Alphameprodine Dimethylthiambutene Norpipanone

Alphamethadol Dioxaphetyl butyrate Phenadoxone

Benzethidine Dipipanone Phenampromide

Betacetylmethadol Ethylmethylthiambutene Phenomorphan

Betameprodine Etonitazene Phenoperidine

Betamethadol Etoxeridine Piritramide

Betaprodine Furethidine Proheptazine

Clonitazene Hydroxypethidine Properidine

Dextromoramide Ketobemidone Propiram

Diampromide Levomoramide Racemoramide

Diethylthiambutene Levophenacylmorphan Trimeperidine

Morpheridine

(b) Any of the following opium derivatives, their salts, isomers, and salts of isomers, unless specifically excepted, when the existence of these salts, isomers, and salts of isomers is possible within the specific chemical designation:

Acetorphine Drotebanol Morphine-N-Oxide

Acetyldihydrocodeine Etorphine Myrophine

Benzylmorphine Heroin Nicocodeine

Codeine methylbromide Hydromorphinol Nicomorphine

Codeine-N-Oxide Methyldesorphine Normorphine

Cyprenorphine Methyldihydromorphine Pholcodine

Desomorphine Morphine methylbromide Thebacon

Dihydromorphine Morphine methylsulfonate 
(c) Any material, compound, mixture, or preparation which contains any quantity of the following hallucinogenic substances, their salts, isomers, and salts of isomers, unless specifically excepted, when the existence of these salts, isomers, and salts of isomers is possible within the specific chemical designation:2-Methylamino-1-phenylpropan-1-one

Some trade and other names:

Methcathinone

Cat

Ephedrone3, 4-methylenedioxy amphetamine

5-methoxy-3, 4-methylenedioxy

amphetamine3, 4, 5-trimethoxy amphetamine

Bufotenine

Some trade and other names:

3-(B-dimethylaminoethyl)-5 hydrozyindole

3-(2-dimethylaminoethyl)-5 indolol

N,N-dimethylserotonin; 5-hydroxy-N-dimethyltryptamine

Mappine2, 5-Dimethoxyamphetamine

Some trade or other names:2, 5-Dimethoxy-a-methylphenethylamine; 2,5-DMA4-Bromo-2, 5-

Dimethoxyamphetamine

Some trade or other names:

4-bromo-2, 5 dimethoxy-a-methylphenethylamine; 4-bromo

2,5-DMADiethyltryptamine

Some trade and other names:

N,N-Diethyltryptamine; DETDimethyltryptamine

Some trade or other names:

DMT4-methyl-2, 5-dimethoxyamphetamine

Some trade and other names:

4-methyl-2, 5-dimethoxy-a-methyl-phenethylamine

DOM, STP4-methoxyamphetamine

Some trade or other names:

4-methoxy-a-methylphenethylamine; paramethoxy amphetamine;

PMAIbogaine

Some trade and other names:

7-Ethyl-6,6a, 7,8,9,10,12,13

Octahydro-2-methoxy-6,9-methano-5H-

pyrido $(1,2: 1,2$ azepino $4,5-b)$ indole

tabernanthe ibogaLysergic acid diethylamideMarihuana, except as otherwise provided in subsection (2)MecloqualoneMescalinePeyoteN-ethyl-3 piperidyl benzilateN-methyl-3 piperidyl benzilatePsilocybinPsilocynThiophene analog of phencyclidine

Some trade or other names:

1-(1-(2-thienyl)cyclohexyl) piperidine)

2-thienyl analog of phencyclidine; TPCP

(d) Except as provided in subsection (2), synthetic equivalents of the substances contained in the plant, or in the resinous extractives of cannabis and synthetic substances, derivatives, and their isomers with similar chemical structure or pharmacological activity, or both, such as the following, are included in schedule 1:

(i) [triangle] $<1>$ cis or trans tetrahydrocannabinol, and their optical isomers. 
(ii) [triangle] $<6>$ cis or trans tetrahydrocannabinol, and their optical isomers.

(iii) [triangle] $<3><,><4>$, cis or trans tetrahydrocannabinol, and their optical isomers.

(e) Compounds of structures of substances referred to in subdivision (d), regardless of numerical designation of atomic positions, are included.

(f) Gamma-hydroxybutyrate and any isomer, salt, or salt of isomer of gamma-hydroxybutyrate.

Some trade and other names:

Sodium oxybate

4-hydroxybutanoic acid monosodium salt

(g) 3,4-methylenedioxymethamphetamine.

Some trade and other names:

Ecstasy

MDMA

(2) Marihuana and the substances described in subsection (1)(d) and (e) in schedule 1 shall be regulated as provided in schedule 2 , if they are dispensed in the manner provided in sections 7335 and 7336.

(3) For purposes of subsection (1), "isomer" includes the optical, position, and geometric isomers.

HISTORY: Act 368, 1978, p 865; imd eff July 25, 1978, by § 25211(1) eff September 30, 1978.

Pub Acts 1978, No. 368, Art. 7, Part 72, § 7212, imd eff July 25, 1978, by § 25211(1) eff September 30, 1978; amended by Pub Acts 1979, No. 125, imd eff October 22, 1979; reenacted without change by Pub Acts 1982, No. 352, imd eff December 21, 1982; amended by Pub Acts 1993, No. 25, imd eff April 20, 1993, by $\S 2$ eff May 1, 1993; 1998, No. 248, imd eff July 9, 1998; 2002, No. 710, imd eff December 30, 2002, by enacting $\S 1$ eff April 1, 2003.

\section{NOTES:}

This section has been reprinted due to a correction in the text.

Effect of amendment notes:

The 1993 amendment in subsection (1) paragraph (c), added "2-Methylamino-1phenylpropan-1-one (trade or other names: methcathinoine; Cat; Ephedrone)" to the schedule.

The 1998 amendment in subsection (1), added paragraph (f).

The 2002 amendment in subsection (1), added paragraph (g).

Statutory references:

Sections 7335 and 7336, above referred to, are $\S \S 333.7335$ and 333.7336 .

LEXIS Publishing Michigan analytical references:

Michigan Law and Practice, Automobiles and Motor Vehicles § 414

Michigan Law and Practice, Public Health and Welfare $\S 171$

\section{CASE NOTES}

Eleven-carboxy-THC, a "metabolite" or byproduct of metabolism created when the body breaks down THC (tetrahydrocannabinol), the psychoactive ingredient of marijuana, is a schedule one controlled substance under MCL $\S$ 333.7212 of the Public Health Code. Thus, a 
person operating a motor vehicle with 11-carboxy-THC in his or her system may be prosecuted under MCL $\S 257.625(8)$, which prohibits the operation of a motor vehicle with any amount of a schedule one controlled substance in the body. People v Derror (2006) 475 Mich 316, 715 NW2d 822.

In a consolidated appeal from two cases involving violations of MCL $\S 257.625(8)$, the trial courts properly ruled that carboxyl tetrahydrocannabinol (THC) was not a schedule 1 controlled substance as it was a benign substance and, therefore, did not meet the criteria for classification as a schedule 1 controlled substance. People v Derror (2005) 268 Mich App 67, 706 NW2d 451, app gr sub nom People v Kurts (2005) 474 Mich 887, 704 NW2d 704 and motion gr, app gr, in part, stay den (2005) 474 Mich 886, 704 NW2d 704. 


\section{Colorado}

\section{Drug Specifics}

All substances defined as a drug (below) and all controlled substances defined below, and gluesniffing, aerosol inhalation, and the inhalation of any other toxic vapor or vapors.

"Cocaine" means coca leaves, except coca leaves and extracts of coca leaves from which cocaine, ecgonine, and derivatives of ecgonine or their salts have been removed; cocaine, its salts, optical and geometric isomers, and salts of isomers; ecgonine, its derivatives, their salts, isomers, and salts of isomers; or any compound, mixture, or preparation which contains any quantity of any of the substances referred to in this subsection (6.5).

"Controlled substance" shall have the same meaning as in section 18-18-102(5), C.R.S.

"Controlled substance analog" means a substance the chemical structure of which is substantially similar to the chemical structure of a controlled substance in schedule I or II and:

Which has a stimulant, depressant, or hallucinogenic effect on the central nervous system substantially similar to the stimulant, depressant, or hallucinogenic effect on the central nervous system of a controlled substance included in schedule I or II; or

With respect to a particular individual, which that individual represents or intends to have a stimulant, depressant, or hallucinogenic effect on the central nervous system substantially similar to the stimulant, depressant, or hallucinogenic effect on the central nervous system of a controlled substance included in schedule I or

"Controlled substance analog" does not include:

A controlled substance;

Any substance for which there is an approved new drug application;

With respect to a particular person, any substance, if an exemption is in effect for investigational use, for that person, under section 505 of the "Federal Food, Drug, and Cosmetic Act", 21 U.S.C. 355 , as amended, to the extent that conduct with respect to the substance is pursuant to the exemption; or

Any substance to the extent not intended for human consumption before such an exemption takes effect with respect to the substance.

"Drug" means any of the substances:

Recognized as drugs in the official United States pharmacopoeia, national formulary, or the official homeopathic pharmacopoeia of the United States, or a supplement thereof;

Intended for use in the diagnosis, cure, mitigation, treatment, or prevention of disease in individuals or animals;

Other than food, intended to affect the structure or any function of the body of individuals or animals; or

Intended for use as a component of any substance specified in subparagraph (I), , or (III) of this paragraph (a).

"Drug" does not include devices or their components, parts, or accessories. 
"Marihuana" or "marijuana" means all parts of the plant cannabis sativa L., whether growing or not, the seeds thereof, the resin extracted from any part of the plant, and every compound, manufacture, salt, derivative, mixture, or preparation of the plant, its seeds, or its resin. It does not include fiber produced from the stalks, oil or cake made from the seeds of the plant, or sterilized seed of the plant which is incapable of germination, if these items exist apart from any other item defined as "marihuana" in this subsection (17). "Marihuana" does not include marihuana concentrate as defined in subsection (18) of this section.

"Marihuana concentrate" means hashish, tetrahydrocannabinols, or any alkaloid, salt, derivative, preparation, compound, or mixture, whether natural or synthesized, of tetrahydrocannabinols.

"Narcotic controlled substance" means any of the following, whether produced directly or indirectly by extraction from substances of vegetable origin, or independently by means of chemical synthesis, or by a combination of extraction and chemical synthesis:

Opium or any opiate or any salt, compound, derivative, or preparation of opium or any opiate;

Any salt, compound, isomer, derivative, or preparation thereof which is chemically equivalent to or identical with any of the substances referred to in paragraph (a) of this subsection (19) but not including the isoquinoline alkaloids of opium;

Any opium poppy or poppy straw.

"Opiate" means any substance having an addiction-forming or addiction-sustaining liability similar to morphine or being capable of conversion into a drug having an addiction-forming or addiction-sustaining liability. "Opiate" does not include, unless specifically designated as controlled under this part 3, the dextrorotatory isomer of 3-methoxy-n-methyl-morphinan and its salts (dextromethorphan). The term does include its racemic and levorotatory forms.

"Opium poppy" means the plant of the species papaver somniferum L., except its seeds.

"Peyote" means all parts of the plant presently classified botanically as lophophora williamsii lemaire, whether growing or not, the seeds thereof, any extraction from any part of such plant, and every compound, manufacture, salt, derivative, mixture, or preparation of such plant or its seeds or extracts.

"Poppy straw" means all parts, except the seeds, of the opium poppy, after mowing.

"Tetrahydrocannabinols" means synthetic equivalents of the substances contained in the plant, or in the resinous extractives of, cannabis, sp., or synthetic substances, derivatives, and their isomers with similar chemical structure and pharmacological activity, such as the following:

cis or trans tetrahydrocannabinol, and their optical isomers;

cis or trans tetrahydrocannabinol, and their optical isomers;

cis or trans tetrahydrocannabinol, and their optical isomers.

Since the nomenclature of the substances listed in paragraph (a) of this subsection (32) is not internationally standardized, compounds of these structures, regardless of the numerical designation of atomic positions, are included in this definition. 


\section{West Virginia}

\section{Drug Specifics}

Any controlled substance or any drug or a combination of alcohol and any controlled substance or drug. 


\section{lowa}

\section{Drug Specifics}

Any drug or controlled substance. 


\section{Wisconsin}

\section{Drug Specifics}

Controlled substances, controlled substance analogs or any other drug.

In an action under par. (am) that is based on the defendant allegedly having a detectable amount of methamphetamine, gamma-hydroxybutyric acid, or delta-9-tetrahydrocannabinol in his or her blood, the defendant has a defense if he or she proves by a preponderance of the evidence that at the time of the incident or occurrence he or she had a valid prescription for methamphetamine or one of its metabolic precursors, gamma-hydroxybutyric acid, or delta-9-tetrahydrocannabinol. 


\section{Delaware}

\section{Drug Specifics}

The provisions of the Act apply only to "illicit or recreational drugs" which under the Act are defined as the class of drugs that are per se illegal (e.g., cocaine or heroin) or certain controlled substances that are designated in the State or federal uniform controlled substances acts and are known to be regularly abused. Designer drugs and inhalants as defined under Delaware law are also included in this Act. 


\section{Georgia}

\section{Drug Specifics}

The per se portion of the law applies to marijuana and its metabolites as well as controlled substance, which means a drug, substance, or immediate precursor in Schedules I through V of Code Sections 16-13-25 through 16-13-29 and Schedules I through V of 21 C.F.R. Part 1308.

TITLE 16. CRIMES AND OFFENSES

CHAPTER 13. CONTROLLED SUBSTANCES

\section{ARTICLE 2. REGULATION OF CONTROLLED SUBSTANCES}

\section{O.C.G.A. § 16-13-25 (2007)}

$\S$ 16-13-25. Schedule I

The controlled substances listed in this Code section are included in Schedule I:

(1) Any of the following opiates, including their isomers, esters, ethers, salts, and salts of isomers, esters, and ethers, unless specifically excepted, pursuant to this article, whenever the existence of these isomers, esters, ethers, and salts is possible within the specific chemical designation:
(A) Acetylmethadol;
(B) Allylprodine;
(C) Reserved;
(D) Alphameprodine;
(E) Alphamethadol;
(F) Benzethidine;
(G) Betacetylmethadol;
(H) Betameprodine;
(I) Betamethadol;
(J) Betaprodine;
(K) Clonitazene;
(L) Dextromoramide;
(M) Dextromorphan;
(N) Diampromide;
(O) Diethylthiambutene;
(P) Dimenoxadol;
(Q) Dimetheptanol;
(R) Dimethylthiambutene;
(S) Dioxaphetyl butyrate;
(T) Dipipanone;
(U) Ethylmethylthiambutene;
(V) Etonitazene;
(W) Etoxeridene;
(X) Furethidine;
(Y) Hydroxypethidine;
(Z) Ketobemidone;
(AA) Levomoramide;
(BB) Levophenacylmorphan; 
(CC) Morpheridine;

(DD) Noracymethadol;

(EE) Norlevorphanol;

(FF) Normethadone;

(GG) Norpipanone;

(HH) Phenadoxone;

(II) Phenampromide;

(JJ) Phenomorphan;

(KK) Phenoperidine;

(LL) Piritramide;

(MM) Proheptazine;

(NN) Properidine;

(OO) Propiram;

(PP) Racemoramide;

(QQ) Trimeperidine;

(2) Any of the following opium derivatives, their salts, isomers, and salts of isomers, unless specifically excepted, whenever the existence of these salts, isomers, and salts of isomers is possible within the specific chemical designation:
(A) Acetorphine;
(B) Acetyldihydrocodeine;
(C) Benzylmorphine;
(D) Codeine methylbromide;
(E) Codeine-N-Oxide;
(F) Cyprenorphine;
(G) Desomorphine;
(H) Dihydromorphine;
(I) Etorphine;
(J) Heroin;
(K) Hydromorphinol;
(L) Methyldesorphine;
(M) Methyldihydromorphine;
(N) Morphine methylbromide;
(O) Morphine methylsulfonate;
(P) Morphine-N-Oxide;
(Q) Myrophine;
(R) Nicocodeine;
(S) Nicomorphine;
(T) Normorphine;
(U) Pholcodine;
(V) Thebacon;

(3) Any material, compound, mixture, or preparation which contains any quantity of the following hallucinogenic substances, their salts, isomers (whether optical, position, or geometrics), and salts of isomers, unless specifically excepted, whenever the existence of these salts, isomers, and salts of isomers is possible within the specific chemical designation:

(A) 3, 4-methylenedioxyamphetamine;

(B) 5-methoxy-3, 4-methylenedioxyamphetamine; 
(C) 3, 4, 5-trimethoxyamphetamine;

(D) Bufotenine;

(E) Diethyltryptamine;

(F) Dimethyltryptamine;

(G) 4-methyl-2, 5-dimethoxyamphetamine;

(H) Ibogaine;

(I) Lysergic acid diethylamide;

(J) Mescaline;

(K) Peyote;

(L) N-ethyl-3-piperidyl benzilate;

(M) N-methyl-3-piperidyl benzilate;

(N) Psilocybin;

(O) Psilocyn (Psilocin);

(P) Tetrahydrocannabinols which shall include, but are not limited to:

(i) All synthetic or naturally produced samples containing more than 15 percent by weight of tetrahydrocannabinols; and

(ii) All synthetic or naturally produced tetrahydrocannabinol samples which do not contain plant material exhibiting the external morphological features of the plant cannabis;

(Q) 2, 5-dimethoxyamphetamine;

(R) 4-bromo-2, 5-dimethoxyamphetamine;

(S) 4-methoxyamphetamine;

(T) Cyanoethylamphetamine;

(U) (1-phenylcyclohexyl) ethylamine;

(V) 1-(1-phenylcyclohexyl) pyrrolidine;

(W) Phencyclidine;

(X) 1-piperidinocyclohexanecarbonitrile;

(Y) 1-phenyl-2-propanone (phenylacetone);

(Z) 3, 4-Methylenedioxymethamphetamine (MDMA);

(AA) 1-methyl-4-phenyl-4-propionoxypiperidine;

(BB) 1-(2-phenylethyl)-4-phenyl-4-acetyloxypiperidine;

(CC) 3-methylfentanyl;

(DD) N-ethyl-3, 4-methylenedioxyamphetamine;

(EE) Para-flurofentanyl;

(FF) 2,5-Dimethoxy-4-Ethylamphetamine;

(GG) Cathinone;

(HH) MPPP (1-Methyl-4-Phenyl-4-Propionoxypiperidine);

(II) PEPAP (1-(2-phenethyl)-4 phenyl-4-acetoxypiperide);

(JJ) Alpha-Methylthiofentanyl;

(KK) Acetyl-Alpha-Methylfentanyl;

(LL) 3-Methylthiofentanyl;

(MM) Beta-Hydroxyfentanyl;

(NN) Thiofentanyl;

(OO) 3,4-Methylenedioxy-N-Ethylamphetamine;

(PP) 4-Methylaminorex;

(QQ) N-Hydroxy-3,4-Methylenedioxyamphetamine;

(RR) Beta-Hydroxy-3-Methylfentanyl; 
(SS) Reserved;

(TT) N, N-Dimethylamphetamine;

(UU) 1-(1-(2-thienyl)cyclohexy)pyrrolidine;

(VV) 4-Bromo-2,5-Dimethoxyphenethylamine (DMPE);

(WW) Alpha-Ethyltryptamine;

(XX) Methcathinone;

(YY) Aminorex;

(4) Any material, compound, mixture, or preparation which contains any of the following substances having a stimulant effect on the central nervous system, including its salts, isomers, and salts of isomers, unless specifically excepted, whenever the existence of these salts, isomers, and salts of isomers is possible within the specific chemical designation:

(A) Fenethylline;

(B) N-(1-benzyl-4-piperidyl)-N-phenylpropanamide (benzyl-fentanyl);

(C) N-(1-(2-thienyl)methyl-4-piperidyl)-N-phenylpropanamide (thenylfentanyl);

(5) Any material, compound, mixture, or preparation which contains any quantity of the following substances, their salts, isomers (whether optical, position, or geometrics), and salts of isomers, unless specifically excepted, whenever the existence of these substances, their salts, isomers, and salts of isomers is possible within the specific chemical designation:

(A) Gamma hydroxybutyric acid (gamma hydroxy butyrate); provided, however, that this does not include any amount naturally and normally occurring in the human body; and

(B) Sodium oxybate, when the FDA approved form of this drug is not:

(i) In a container labeled in compliance with subsection (a) or (b) of Code Section 26-38 ; and

(ii) In the possession of:

(I) A registrant permitted to dispense the drug;

(II) Any person other than to whom the drug was prescribed; or

(III) Any person who attempts to or does unlawfully possess, sell, distribute, or give this drug to any other person;

(6) Notwithstanding the fact that Schedule I substances have no currently accepted medical use, the General Assembly recognizes certain of these substances which are currently accepted for certain limited medical uses in treatment in the United States but have a high potential for abuse. Accordingly, unless specifically excepted or unless listed in another schedule, any material, compound, mixture, or preparation which contains any quantity of methaqualone, including its salts, isomers, optical isomers, salts of their isomers, and salts of these optical isomers, is included in Schedule I;

(7) 2,5-Dimethoxy-4-(n)-propylthiophenethylamine (2C-T-7);

(8) 1-(3-Trifluromethylphenyl) Piperazine (TFMPP);

(9) N-Benzylpiperazine (BZP);

(10) 5-Methoxy-N,N-Diisopropyltryptamine (5-MeO-DIPT);

(11) Alpha-Methyltryptamine (AMT). 
HISTORY: Code 1933, § 79A-806, enacted by Ga. L. 1974, p. 221, § 1; Ga. L. 1978, p. 1668, § 6; Ga. L. 1979, p. 859, § 5; Ga. L. 1980, p. 1746, § 4; Ga. L. 1981, p. 557, § 3; Ga. L. 1982, p. 2403, §§ 11, 16; Ga. L. 1984, p. 22, § 16; Ga. L. 1984, p. 1019, § 1; Ga. L. 1985, p. 1219, § 2; Ga. L. 1986, p. 1555, § 3; Ga. L. 1987, p. 261, § 1; Ga. L. 1989, p. 233, § 1; Ga. L. 1990, p. 8, § 16; Ga. L. 1990, p. 640, § 1; Ga. L. 1992, p. 1131, § 1; Ga. L. 1994, p. 169, §§ 1-3, 3.1; Ga. L. 1996, p. 356, § 1; Ga. L. 2001, p. 816, § 1; Ga. L. 2002, p. 415, § 16; Ga. L. 2003, p. 349, § 2; Ga. L. 2005, p. 1028, § 1/SB 89; Ga. L. 2006, p. 219, § 1/HB 1054.

\section{NOTES:}

THE 2005 AMENDMENT, effective May 9, 2005, substituted a semicolon for the period at the end of paragraph (9) and added paragraphs (10) and (11).

THE 2006 AMENDMENT, effective April 19, 2006, added "(Psilocin)" at the end of subparagraph (3)(O); added "(MDMA)" at the end of subparagraph (3)(Z); and in subparagraph (3)(SS), substituted "Reserved" for "MDMA (3, 4 Methylene Dioxymethamphetamine)".

CODE COMMISSION NOTES. --Pursuant to Code Section 28-9-5, in 1986, in subparagraph (3)(DD) "N-ethyl-3" was substituted for "n-ethyl-3".

ADMINISTRATIVE RULES AND REGULATIONS. --Definition of narcotic drugs, Official Compilation of Rules and Regulations of State of Georgia, Rules of Georgia State Board of Pharmacy, Chapter 480-17. Exemptions from Georgia Controlled Substances Act, Official Compilation of Rules and Regulations of State of Georgia, Rules of Georgia State Board of Pharmacy, Chapter 480-18. Registration requirements, Official Compilation of Rules and Regulations of State of Georgia, Rules of Georgia State Board of Pharmacy, Chapter 480-20.

LAW REVIEWS. --For survey article on criminal law and procedure, see 34 Mercer L. Rev. 89 (1982).

\section{JUDICIAL DECISIONS}

"MARIJUANA" DEFINED. --Construction of $\S 16-13-21(16)$ with O.C.G.A. § 16-13-25(3) as to what constitutes marijuana. Osborn v. State, 161 Ga. App. 132, 291 S.E.2d 22 (1982).

MARIJUANA AND THC. --Any sample containing tetrahydrocannabinols (THC) which would otherwise fall under the definition of marijuana shall be considered marijuana unless it either contains more than 15 percent by weight of THC or does not exhibit the external morphological features of the plant cannabis. Osborn v. State, 161 Ga. App. 132, 291 S.E.2d 22 (1982).

Since a prosecution for misdemeanor possession of marijuana cannot be instituted on the basis of a blood or urine test which shows "positive" for marijuana, because such positive showings will be based upon the presence of THC "without the morphological features" of the marijuana plant and are thus excluded from the definition of "marijuana" under the Georgia Controlled Substances Act, O.C.G.A. $§ 16-13-20$ et seq., prosecutions for possession of marijuana based upon positive blood or urine samples must be brought as a felony prosecution for possession of a Schedule I drug, i.e. THC. Cronan v. State, 236 Ga. App. 374, 511 S.E.2d 899 (1999). 
Despite the defendant's contrary claim, the state was not required to prove the tetrahydrocannabinol (THC) content of the plant material seized in a prosecution for trafficking in marijuana; further, THC was treated separately in the criminal code as a Schedule I drug under O.C.G.A. § 16-13-25(3)(P). Trujillo v. State, 286 Ga. App. 438, 649 S.E.2d 573 (2007).

HEROIN IS A SCHEDULE I DRUG. --Fatal variance between the allegations of the indictment and the evidence presented at defendant's trial for trafficking in heroin did not exist as the trial court was able to take judicial notice of the rules promulgated by the State Board of Pharmacy under the Administrative Procedures Act; pursuant to O.C.G.A. § 16-13-25(2)(J), heroin was a Schedule I drug. Bailey v. State, 259 Ga. App. 293, 576 S.E.2d 668 (2003).

STATE MUST PROVE THC WAS SYNTHETICALLY DERIVED TO SUSTAIN CHARGE OF POSSESSION OR DISTRIBUTION. --Any substance which is a resin, compound, manufacture, salt, derivative mixture, or preparation of the cannabis plant shall be treated as marijuana, even though it may contain a high percentage of tetrahydrocannabinols (THC). For the state to sustain a charge of possession or distribution of THC under O.C.G.A. $\S$ 16-1325(3)(P)(i), it must prove that the THC is not a compound, derivative, or preparation of the cannabis plant; that is, it must prove that the THC is synthetically derived. Aycock v. State, 146 Ga. App. 489, 246 S.E.2d 489 (1978).

\section{INDICTMENT CHARGING DEFENDANT WITH SELLING "PHENYLCYCLOHEXYL} ETHYLAMINE" INSTEAD OF "1-PHENYLCYCLOHEXYL ETHYLAMINE," WAS

SUFFICIENT because it did not misinform defendant as to offense charged in such manner that it either impaired defendant's ability to prepare a defense, or surprised defendant at trial, and defendant could not be subjected to a subsequent prosecution for same offense. Murray v. State, 157 Ga. App. 596, 278 S.E.2d 2 (1981).

ENTRAPMENT. --The fact that a government informer furnished the contraband to a defendant does not constitute entrapment. Venable v. State, 203 Ga. App. 517, 417 S.E.2d 347, cert. denied, 203 Ga. App. 908, 417 S.E.2d 347 (1992).

EVIDENCE DOES NOT DEMAND FINDING OF ENTRAPMENT. --The fact that defendant may have wished to "get in good" with the female undercover agent and that, without any undue encouragement on the agent's part, the defendant believed the informant's statement that the defendant could accomplish that by providing the agent with marijuana, this would not demand a finding of entrapment. Venable v. State, 203 Ga. App. 517, 417 S.E.2d 347, cert. denied, 203 Ga. App. 908, 417 S.E.2d 347 (1992).

EVIDENCE INSUFFICIENT FOR FINDING OF POSSESSION OF MARIJUANA. -Defendant's conviction for possession of marijuana had to fail because in the absence of conclusive, scientific tests, the possibility remained that the substance at issue was not marijuana. Chambers v. State, 260 Ga. App. 48, 579 S.E.2d 71 (2003).

SUFFICIENT EVIDENCE TO SUPPORT CONVICTION FOR POSSESSION OF MDMA. -Because the defendant's admission to possessing MDMA was direct evidence supporting guilt, and said admission served as a direct connection to the contraband, the trial court did not err in 
denying the defendant's motion for a new trial based on the insufficiency of the evidence. Barrino v. State, 282 Ga. App. 496, 639 S.E.2d 489 (2006).

CITED in Weaver v. State, 145 Ga. App. 194, 243 S.E.2d 560 (1978); Plemons v. State, 155 Ga. App. 447, 270 S.E.2d 836 (1980); Little v. State, 157 Ga. App. 462, 278 S.E.2d 17 (1981);

Bennett v. State, 158 Ga. App. 421, 280 S.E.2d 429 (1981); Hartley v. State, 159 Ga. App. 157, 282 S.E.2d 684 (1981).

\section{RESEARCH REFERENCES}

AM. JUR. 2D. --25 Am. Jur. 2d, Drugs and Controlled Substances, $\S 8$.

C.J.S. --28 C.J.S., Drugs and Narcotics, $\S \S 122,173,174$.

U.L.A. --Uniform Controlled Substances Act (U.L.A.) § 204.

ALR. --Federal prosecutions based on manufacture, importation, transportation, possession, sale, or use of LSD, 22 ALR3d 1325.

Free exercise of religion as defense to prosecution for narcotic or psychedelic drug offense, 35 ALR3d 939.

Marijuana, psilocybin, peyote, or similar drugs of vegetable origin as narcotics for purposes of drug prosecutions, 50 ALR3d 1164.

LSD, STP, MDA, or other chemically synthesized hallucinogenic or psychedelic substances as narcotics for purposes of drug prosecution, 50 ALR3d 1284.

TITLE 16. CRIMES AND OFFENSES

CHAPTER 13. CONTROLLED SUBSTANCES

ARTICLE 2. REGULATION OF CONTROLLED SUBSTANCES

O.C.G.A. § 16-13-26 (2007)

$\S 16-13-26$. Schedule II

The controlled substances listed in this Code section are included in Schedule II:

(1) Any of the following substances, or salts thereof, except those narcotic drugs specifically exempted or listed in other schedules, whether produced directly or indirectly by extraction from substances of vegetable origin, or independently by extraction from substances of vegetable origin, or independently by means of chemical synthesis, or by combination of extraction and chemical synthesis:

(A) Opium and opiate, and any salt, compound, derivative, or preparation of opium or opiate, excluding nalox one hydrochloride, but including the following:

(i) Raw opium;

(ii) Opium extracts;

(iii) Opium fluid extracts;

(iv) Powdered opium;

(v) Granulated opium;

(vi) Tincture of opium; 
(vii) Codeine;

(viii) Ethylmorphine;

(ix) Hydrocodone;

(x) Hydromorphone;

(xi) Metopon;

(xii) Morphine;

(xiii) Oxycodone;

(xiv) Oxymorphone;

(xv) Thebaine;

(B) Any salt, compound, isomer, derivative, or preparation thereof which is chemically equivalent or identical with any of the substances referred to in subparagraph (A) of this paragraph, except that these substances shall not include the isoquinoline alkaloids of opium;

(C) Opium poppy and poppy straw;

(D) Cocaine, coca leaves, any salt, compound, derivative, stereoisomers of cocaine, or preparation of coca leaves, and any salt, compound, derivative, stereoisomers of cocaine, or preparation thereof which is chemically equivalent or identical with any of these substances, but not including decocainized coca leaves or extractions which do not contain cocaine or ecgonine;

(2) Any of the following opiates, including their isomers, esters, ethers, salts, and salts of isomers, whenever the existence of these isomers, esters, ethers, and salts is possible within the specific chemical designation:

(A) Alfentanil;

(A.1) Alphaprodine;

(B) Anileridine;

(C) Bezitramide;

(D) Dihydrocodeine;

(E) Diphenoxylate;

(F) Fentanyl;

(G) Isomethadone;

(G.5) Levo-alphacetylmethadol (some other names: levomethadyl acetate, LAAM);

(H) Levomethorphan;

(I) Levorphanol;

(J) Methazocine;

(K) Methadone;

(L) Methadone-Intermediate, 4-cyano-2-dimethylamino-4, 4-di-

phenyl butane;

(M) Moramide-Intermediate, 2-methyl-3-morpholino-1, 1-diphenylpropane-carboxylic acid;

(N) Pethidine (meperidine);

(O) Pethidine-Intermediate-A, 4-cyano-1-methyl-4-phenylpiperidine;

(P) Pethidine-Intermediate-B, ethyl-4-phenylpiperidine-4- carboxylate;

(Q) Pethidine-Intermediate-C, 1-methyl-4-phenylpiperidine-4- carboxylic acid;

(R) Phenazocine;

(S) Piminodine; 
(T) Racemethorphan;

(U) Racemorphan;

(U.1) Remifentanil;

(V) Sufentanil;

(3) Unless specifically excepted or unless listed in another schedule, any material, compound, mixture, or preparation which contains any quantity of the following substances included as having a stimulant effect on the central nervous system:

(A) Amphetamine, its salts, optical isomers, and salts of its optical isomers;

(B) Any substance which contains any quantity of methamphetamine, including its salts, isomers, and salts of isomers;

(C) Phenmetrazine and its salts;

(D) Methylphenidate;

(E) Carfentanil;

(F) Nabilone;

(4) Unless specifically excepted or unless listed in another schedule, any material, compound, mixture, or preparation which contains any of the following substances included as having a depressant effect on the central nervous system, including its salts, isomers, and salts of isomers whenever the existence of such salts, isomers, and salts of isomers is possible within the specific chemical designation:
(A) Amobarbital;
(A.5) Glutethimide;
(B) Secobarbital;
(C) Pentobarbital.

HISTORY: Code 1933, § 79A-807, enacted by Ga. L. 1974, p. 221, § 1; Ga. L. 1977, p. 625, § 7; Ga. L. 1978, p. 1668, § 7; Ga. L. 1979, p. 859, §§ 6, 7; Ga. L. 1980, p. 1746, § 5; Ga. L. 1982, p. 2403, §§ 12, 17, 17.1; Ga. L. 1985, p. 1219, § 3; Ga. L. 1987, p. 261, §§ 2-4; Ga. L. 1988, p. 420, $\S 1$; Ga. L. 1989, p. 233, § 2; Ga. L. 1992, p. 1131, § 2; Ga. L. 1994, p. 169, § 4; Ga. L. 1997, p. 1311, § 1; Ga. L. 2000, p. 1317, § 1; Ga. L. 2007, p. 605, § 1/HB 286.

\section{NOTES:}

THE 2007 AMENDMENT, effective May 29, 2007, deleted subparagraph (3)(G) which read: "Dimethylamphetamine;".

ADMINISTRATIVE RULES AND REGULATIONS. --Definition of narcotic drug, Official Compilation of Rules and Regulations of State of Georgia, Rules of Georgia State Board of Pharmacy, Chapter 480-17. Exemptions from Georgia Controlled Substances Act, Official Compilation of Rules and Regulations of State of Georgia, Rules of Georgia State Board of Pharmacy, Chapter 480-17. Requirement of a prescription, Official Compilation of Rules and Regulations of State of Georgia, Rules of Georgia State Board of Pharmacy, Chapter 480-22.

LAW REVIEWS. --For survey article on criminal law and procedure, see 34 Mercer L. Rev. 89 (1982).

For note on airport searches of drug couriers, see 33 Mercer L. Rev. 433 (1981). 


\section{JUDICIAL DECISIONS}

CONSTRUED WITH O.C.G.A. §§ 16-13-30 AND 16-13-31. --Where the total weight of the substances seized from defendant was only 24.4 grams of cocaine, defendant argued that the only Georgia statute that proscribes possession of cocaine is O.C.G.A. § 16-13-31, prohibiting possession of 28 grams or more of cocaine. However, although O.C.G.A. § 16-13-31 deals with being in knowing, actual possession of 28 grams or more of cocaine or any mixture containing cocaine, O.C.G.A. § 16-13-26(1)(D) (prior to 1988 amendment inserting "cocaine") lists "Coca leaves, any salt, compound, derivative, stereoisomers of cocaine, or preparation of coca leaves, and any salt, compound, derivative, stereoisomers of cocaine, ...," which includes cocaine. Under O.C.G.A. § 16-13-30, the unlawful possession of any controlled substance, regardless of amount, constitutes an offense. Dixon v. State, 180 Ga. App. 222, 348 S.E.2d 742 (1986) (decided prior to 1988 amendment inserting "cocaine" at the beginning of paragraph (1)(D)).

METHYLPHENIDATE POSSESSOR'S EX POST FACTO ARGUMENT REJECTED. -Methylphenidate has been a Schedule II controlled substance since 1974. Accordingly, the contention that defendant was sentenced for an ex post facto crime has no merit where defendant's arrest warrant stated the date of possession of methylphenidate to have been on or about July 25, 1985. Carter v. State, 180 Ga. App. 173, 348 S.E.2d 715 (1986).

SIMULTANEOUS POSSESSION OF DIFFERENT PROSCRIBED DRUGS may result in multiple punishments. Howard v. State, 144 Ga. App. 208, 240 S.E.2d 908 (1977).

MULTIPLE OFFENSES ARISING FROM SIMULTANEOUS POSSESSION OF DRUGS OF SAME CATEGORY. --Multiple offenses can be charged when drugs of same category (i.e., Schedule II) are taken from one person at same time and place. Howard v. State, 144 Ga. App. 208, 240 S.E.2d 908 (1977).

A defendant may be prosecuted, convicted and separately sentenced for the simultaneous possession of each of the controlled substances listed in O.C.G.A. § 16-13-26. Tabb v. State, 250 Ga. 317, 297 S.E.2d 227 (1982).

CONTROLLED SUBSTANCE. --Cocaine was a controlled substance pursuant to O.C.G.A. § 16-13-26(1)(D), and thus defendant could be convicted both for selling a controlled substance and distributing a controlled substance within 1,000 feet of a housing project after defendant sold cocaine to an undercover informant. Dixon v. State, 252 Ga. App. 385, 556 S.E.2d 480 (2001).

Sufficient evidence supported defendant's conviction of possession of cocaine under O.C.G.A. $\S 16-13-30$ (a), as: (1) the informant testified that defendant procured crack cocaine for the informant for $\$ 300.00$; (2) detectives witnessed defendant enter and exit the bar where, according to the informant, defendant obtained the cocaine; and (3) the substance tested positive for cocaine, a controlled substance under O.C.G.A. § 16-13-26(1)(D); the credibility of the informant, which, according to defendant, was allegedly impaired by the informant's prior criminal conduct, was an issue for the jury. Ross v. State, 275 Ga. App. 137, 619 S.E.2d 809 (2005).

CITED in Nix v. State, 135 Ga. App. 672, 219 S.E.2d 6 (1975); Partain v. State, 139 Ga. App. 325, 228 S.E.2d 292 (1976); Cole v. State, 142 Ga. App. 461, 236 S.E.2d 125 (1977); Elrod v. 
State, 143 Ga. App. 331, 238 S.E.2d 291 (1977); Hughes v. State, 150 Ga. App. 90, 256 S.E.2d 634 (1979); Robinson v. State, 244 Ga. 15, 257 S.E.2d 523 (1979); Crosby v. State, 150 Ga. App. 804, 258 S.E.2d 593 (1979); Rick v. State, 152 Ga. App. 519, 263 S.E.2d 213 (1979); Farmer v. State, 154 Ga. App. 673, 270 S.E.2d 26 (1980); Plemons v. State, 155 Ga. App. 447, 270 S.E.2d 836 (1980); Wood v. State, 156 Ga. App. 810, 275 S.E.2d 694 (1980); Tant v. State, 247 Ga. 264, 275 S.E.2d 312 (1981); Little v. State, 157 Ga. App. 462, 278 S.E.2d 17 (1981); Ward v. State, 248 Ga. 60, 281 S.E.2d 503 (1981); Hartley v. State, 159 Ga. App. 157, 282 S.E.2d 684 (1981); Head v. State, 160 Ga. App. 4, 285 S.E.2d 735 (1981); Reece v. State, 160 Ga. App. 59, 286 S.E.2d 41 (1981); Boyer v. State, 178 Ga. App. 372, 343 S.E.2d 146 (1986); Santone v. State, 187 Ga. App. 789, 371 S.E.2d 428 (1988); Helmeci v. State, 230 Ga. App. 866, 498 S.E.2d 326 (1998); Davis v. State, 232 Ga. App. 882, 502 S.E.2d 779 (1998); Daniels v. State, 244 Ga. App. 522, 536 S.E.2d 206 (2000); Salgado v. State, 268 Ga. App. 18, 601 S.E.2d 417 (2004); Thomas v. State, 287 Ga. App. 500, 651 S.E.2d 801 (2007).

\section{RESEARCH REFERENCES}

AM. JUR. 2D. --25 Am. Jur. 2d, Drugs and Controlled Substances, $\S 8$.

C.J.S. --28 C.J.S., Drugs and Narcotics, § 122.

U.L.A. --Uniform Controlled Substances Act (U.L.A.) $§ 206$.

\section{TITLE 16. CRIMES AND OFFENSES} CHAPTER 13. CONTROLLED SUBSTANCES ARTICLE 2. REGULATION OF CONTROLLED SUBSTANCES

O.C.G.A. § 16-13-27 (2007)

\section{$\S 16-13-27$. Schedule III}

The controlled substances listed in this Code section are included in Schedule III:

(1) Unless specifically excepted or unless listed in another schedule, any material, compound, mixture, or preparation which contains any quantity of the following substances, included as having a stimulant effect on the central nervous system, including its salts, isomers (whether optical, position, or geometric), and salts of such isomers whenever the existence of such salts, isomers, and salts of isomers is possible within the specific chemical designation:

(A) Those compounds, mixtures, or preparations in dosage unit forms containing any stimulant substances which are listed as excepted compounds by the State Board of Pharmacy pursuant to this article, and any other drug of quantitative composition so excepted or which is the same except that it contains a lesser quantity of controlled substances;

(B) Benzphetamine;

(C) Chlorphentermine;

(D) Clortermine;

(E) Phendimetrazine;

(2) Unless specifically excepted or unless listed in another schedule, any material, compound, mixture, or preparation which contains any quantity of the following substances included as having a depressant effect on the central nervous system: 
(A) Any compound, mixture, or preparation containing amobarbital, secobarbital, pentobarbital, or any salts thereof and one or more active medicinal ingredients which are not listed in any schedule;

(B) Any suppository dosage form containing amobarbital, secobarbital, pentobarbital, or any salt of any of these drugs and approved by the State Board of Pharmacy for marketing only as a suppository; salt thereof;

(C) Any substance which contains any quantity of a derivative of barbituric acid or any

(D) Chlorhexadol;

(E) Reserved;

(F) Lysergic acid;

(G) Lysergic acid amide;

(H) Methyprylon;

(I) Sulfondiethylmethane;

(J) Sulfonethylmethane;

(K) Sulfonmethane;

(L) Tiletamine/Zolozepam (Telazol);

(3) Nalorphine;

(4) Unless specifically excepted or unless listed in another schedule, any material, compound, mixture, or preparation containing limited quantities of the following narcotic drugs, or any salts thereof:

(A) Not more than 1.8 grams of codeine, or any of its salts, per 100 milliliters or not more than 90 milligrams per dosage unit, with an equal or greater quantity of an isoquinoline alkaloid of opium;

(B) Not more than 1.8 grams of codeine, or any of its salts, per 100 milliliters or not more than 90 milligrams per dosage unit, with one or more active, nonnarcotic ingredients in recognized therapeutic amounts;

(C) Not more than 300 milligrams of dihydrocodeinone (hydrocodone), or any of its salts, per 100 milliliters or not more than 15 milligrams per dosage unit, with a fourfold or greater quantity of an isoquinoline alkaloid of opium;

(D) Not more than 300 milligrams of dihydrocodeinone (hydrocodone), or any of its salts, per 100 milliliters or not more than 15 milligrams per dosage unit, with one or more active, nonnarcotic ingredients in recognized therapeutic amounts;

(E) Not more than 1.8 grams of dihydrocodeine, or any of its salts, per 100 milliliters or not more than 90 milligrams per dosage unit, with one or more active, nonnarcotic ingredients in recognized therapeutic amounts;

(F) Not more than 300 milligrams of ethylmorphine, or any of its salts, per 100 milliliters or not more than 15 milligrams per dosage unit, with one or more active, nonnarcotic ingredients in recognized therapeutic amounts;

(G) Not more than 500 milligrams of opium per 100 milliliters or per 100 grams, or not more than 25 milligrams per dosage unit, with one or more active, nonnarcotic ingredients in recognized therapeutic amounts; 
(H) Not more than 50 milligrams of morphine, or any of its salts, per 100 milliliters or per 100 grams with one or more active, nonnarcotic ingredients in recognized therapeutic amounts;

(5) The State Board of Pharmacy may except by rule any compound, mixture, or preparation containing any stimulant or depressant substance listed in paragraphs (1) and (2) of this Code section from the application of all or any part of this article if the compound, mixture, or preparation contains one or more active, medicinal ingredients not having a stimulant or depressant effect on the central nervous system, and if the admixtures are included therein in combinations, quantity, proportion, or concentration that vitiate the potential for abuse of the substances which have a stimulant or depressant effect on the central nervous system;

(6) Any anabolic steroid or any salt, ester, or isomer of a drug or substance described or listed in this paragraph, if that salt, ester, or isomer promotes muscle growth. Such term does not include an anabolic steroid which is expressly intended for administration through implants to cattle or other nonhuman species and which has been approved by the secretary of health and human services for such administration:

(A) Boldenone;

(B) Chlorotestosterone;

(C) Clostebol;

(D) Dehydrochlormethyltestosterone;

(E) Dihydrotestosterone;

(F) Drostanolone;

(G) Ethylestrenol;

(H) Fluoxymesterone;

(I) Formebolone;

(J) Mesterolone;

(K) Methandienone;

(L) Methandranone;

(M) Methandriol;

(N) Methandrostenolone;

(O) Methenolone;

(P) Methyltestosterone;

(Q) Mibolerone;

(R) Nandrolone;

(S) Norethandrolone;

(T) Oxandrolone;

(U) Oxymesterone;

(V) Oxymetholone;

(W) Stanolone;

(X) Stanozolol;

(Y) Testolactone;

(Z) Testosterone;

(AA) Trenbolone;

(7) Ketamine;

(8) Dronabinol (synthetic) in sesame oil and encapsulated in a U.S. Food and Drug Administration approved drug product also known as Marinol; 
(9) Sodium oxybate, when the FDA approved form of this drug is in a container labeled in compliance with subsection (a) or (b) of Code Section 26-3-8, in the possession of a registrant permitted to dispense the drug, or in the possession of a person to whom it has been lawfully prescribed;

(10) Buprenorphine.

HISTORY: Code 1933, § 79A-808, enacted by Ga. L. 1974, p. 221, § 1; Ga. L. 1978, p. 1668, § 8; Ga. L. 1980, p. 1746, § 6; Ga. L. 1982, p. 3, § 16; Ga. L. 1982, p. 2403, §§ 13, 18; Ga. L. 1989, p. 233, § 3; Ga. L. 1991, p. 312, § 1; Ga. L. 1992, p. 6, § 16; Ga. L. 1992, p. 1131, §§ 3, 4; Ga. L. 1996, p. 356, § 2; Ga. L. 1997, p. 1311, § 2; Ga. L. 1998, p. 778, § 1; Ga. L. 2000, p. 1317, § 2; Ga. L. 2003, p. 349, § 3.

\section{NOTES:}

CODE COMMISSION NOTES. --Pursuant to Code Section 28-9-5, in 1996, a semicolon was substituted for a period at the end of subparagraph $(4)(\mathrm{H})$, at the end of paragraph $(5)$, and at the end of subparagraph (6)(AA).

ADMINISTRATIVE RULES AND REGULATIONS. --Definition of narcotic drug, Official Compilation of Rules and Regulations of State of Georgia, Rules of Georgia State Board of Pharmacy, Chapter 480-17. Exemptions from Georgia Controlled Substances Act, Official Compilation of Rules and Regulations of State of Georgia, Rules of Georgia State Board of Pharmacy, Chapter 480-17. Requirements of a prescription drug order, Official Compilation of Rules and Regulations of State of Georgia, Rules of Georgia State Board of Pharmacy, Chapter 480-22.

\section{JUDICIAL DECISIONS}

CITED in Williamson v. State, 134 Ga. App. 864, 216 S.E.2d 684 (1975); Nix v. State, 135 Ga. App. 672, 219 S.E.2d 6 (1975); Cadle v. State, 136 Ga. App. 232, 221 S.E.2d 59 (1975); Chesser v. State, 141 Ga. App. 657, 234 S.E.2d 121 (1977); Taylor v. State, 144 Ga. App. 534, 241 S.E.2d 590 (1978); Taylor v. State, 149 Ga. App. 362, 254 S.E.2d 432 (1979); Robinson v. State, 244 Ga. 15, 257 S.E.2d 523 (1979); Little v. State, 157 Ga. App. 462, 278 S.E.2d 17 (1981); Printup v. State, 159 Ga. App. 574, 284 S.E.2d 82 (1981); Sosebee v. State, 282 Ga. App. 905, 640 S.E.2d 379 (2006).

\section{RESEARCH REFERENCES}

AM. JUR. 2D. --25 Am. Jur. 2d, Drugs and Controlled Substances, $\S 8$.

C.J.S. --28 C.J.S., Drugs and Narcotics, $\S \S 30,119,122$.

U.L.A. --Uniform Controlled Substances Act (U.L.A.) § 208.

TITLE 16. CRIMES AND OFFENSES

CHAPTER 13. CONTROLLED SUBSTANCES

ARTICLE 2. REGULATION OF CONTROLLED SUBSTANCES

O.C.G.A. § 16-13-28 (2007) 


\section{$\S 16-13-28$. Schedule IV}

(a) The controlled substances listed in this Code section are included in Schedule IV. Unless specifically excepted or unless listed in another schedule, any material, compound, mixture, or preparation which contains any quantity of the following substances, including its salts, isomers, and salts of isomers whenever the existence of such salts, isomers, and salts of isomers is possible within the specified chemical designation, included as having a stimulant or depressant effect on the central nervous system or a hallucinogenic effect:

(1) Alprazolam;

(2) Barbital;

(2.1) Bromazepam;

(2.15) Butorphanol;

(2.2) Camazepam;

(2.25) Carisoprodol;

(2.3) Cathine;

(3) Chloral betaine;

(4) Chloral hydrate;

(5) Chlordiazepoxide, but not including librax (chlordiazepoxide hydrochloride and clidinium bromide) or menrium (chlordiazepoxide and water soluble esterified estrogens);

(5.1) Clobazam;

(6) Clonazepam;

(7) Clorazepate;

(7.1) Clotiazepam;

(7.2) Cloxazolam;

(7.3) Delorazepam;

(8) Desmethyldiazepam;

(8.5) Dexfenfluramine;

(9) Reserved;

(10) Diazepam;

(11) Diethylpropion;

(11.05) Difenoxin;

(11.1) Estazolam;

(12) Ethchlorvynol;

(13) Ethinamate;

(13.1) Ethyl loflazepate;

(13.2) Fencamfamin;

(14) Fenfluramine;

(14.1) Flunitrazepam;

(14.2) Fenproporex;

(15) Flurazepam;

(16) Halazepam;

(16.1) Haloxazolam;

(16.2) Ketazolam;

(16.3) Lometazepam;

(16.4) Loprazolam;

(17) Lorazepam; 
(18) Mazindol;

(19) Mebutamate;

(19.1) Medazepam;

(19.2) Mefenorex;

(20) Meprobamate;

(21) Methohexital;

(22) Methylphenobarbital;

(22.1) Midazolam;

(22.15) Modafinil;

(22.2) Nimetazepam;

(22.3) Nitrazepam;

(22.4) Nordiazepam;

(23) Oxazepam;

(23.1) Oxazolam;

(24) Paraldehyde;

(25) Pemoline;

(26) Pentazocine;

(27) Petrichloral;

(28) Phenobarbital;

(29) Phentermine;

(29.1) Pipradrol;

(30) Prazepam;

(30.05) Propoxyphene (including all salts and optical isomers);

(30.1) Quazepam;

(30.2) Sibutramine;

(30.3) SPA (-)-1-dimethylamino-1, 2-diphenylethane;

(31) Temazepam;

(32) Triazolam;

(32.5) Zaleplon;

(33) Zolpidem;

(34) Zopiclone.

(b) The State Board of Pharmacy may except by rule any compound, mixture, or preparation containing any depressant, stimulant, or hallucinogenic substance listed in subsection (a) of this Code section from the application of all or any part of this article if the compound, mixture, or preparation contains one or more active, medicinal ingredients not having a depressant or stimulant effect on the central nervous system, and if the admixtures are included therein in combinations, quantity, proportion, or concentration that vitiate the potential for abuse of the substances which have a depressant or stimulant effect on the central nervous system.

HISTORY: Code 1933, § 79A-809, enacted by Ga. L. 1974, p. 221, § 1; Ga. L. 1977, p. 1287, § 1; Ga. L. 1979, p. 859, § 8; Ga. L. 1980, p. 1746, § 7; Ga. L. 1981, p. 557, § 4; Ga. L. 1982, p. 3, $\S 16$; Ga. L. 1982, p. 2403, §§ 14, 19; Ga. L. 1984, p. 22, § 16; Ga. L. 1985, p. 1219, § 4; Ga. L. 1986, p. 10, § 16; Ga. L. 1986, p. 1555, § 4; Ga. L. 1987, p. 261, § 5; Ga. L. 1989, p. 233, § 4; Ga. L. 1990, p. 8, § 16; Ga. L. 1993, p. 590, § 2; Ga. L. 1994, p. 169, § 5; Ga. L. 1996, p. 1023, § 1; Ga. L. 1997, p. 1311, § 3; Ga. L. 1998, p. 778, § 2; Ga. L. 1999, p. 643, § 1; Ga. L. 2000, p. 
1317, § 3; Ga. L. 2003, p. 349, § 4; Ga. L. 2006, p. 219, § 2/HB 1054; Ga. L. 2007, p. 47, § 16/SB 103.

\section{NOTES:}

THE 2006 AMENDMENT, effective April 19, 2006, substituted a semicolon for a period at the end of paragraph (a)(33); and added paragraph (a)(34).

THE 2007 AMENDMENT, effective May 11, 2007, part of an Act to revise, modernize, and correct the Code, deleted ", and all salts, isomers, and salts of isomers thereof" following "Zopiclone" in paragraph (a)(34).

CODE COMMISSION NOTES. --Pursuant to Code Section 28-9-5, in 1998, the new paragraph added in 1998 was redesignated as paragraph (a)(30.2), and former paragraph (a)(30.2) was redesignated as paragraph $(\mathrm{a})(30.3)$.

EDITOR'S NOTES. --Ga. L. 1996, p. 356, § 2 added butorphanol to the list of Schedule III controlled substances. Ga. L. 1996, p. 1023, § 1 added butorphanol to the list of Schedule IV controlled substances. The Governor signed Ga. L. 1996, p. 356 on April 1, 1996, and Ga. L. 1996, p. 1023 on April 15, 1996.

ADMINISTRATIVE RULES AND REGULATIONS. --Definition of narcotic drug, Official Compilation of Rules and Regulations of State of Georgia, Rules of Georgia State Board of Pharmacy, Chapter 480-17. Exemptions from Georgia Controlled Substances Act, Official Compilation of Rules and Regulations of State of Georgia, Rules of Georgia State Board of Pharmacy, Chapter 480-17. Requirements of a prescription drug order, Official Compilation of Rules and Regulations of State of Georgia, Rules of Georgia State Board of Pharmacy, Chapter $480-22$.

\section{JUDICIAL DECISIONS}

CONSTITUTIONALITY. --Former Code 1933, § 79A-809 was not unconstitutional as violative of Ga. Const. 1976, Art. I, Sec. II, Para. IV, and Art. III, Sec. I, Para. I (see now Ga. Const. 1983, Art. I, Sec. II, Para. III, and Art. III, Sec. I, Para. I), which sections deal with separation of powers and delegations of legislative power respectively. Harmon v. State, 235 Ga. 329, 219 S.E.2d 441 (1975) (see O.C.G.A. § 16-13-28).

IDENTIFICATION OF DRUG. --Mere proof of a trade name of a controlled substance is insufficient evidence to sustain a conviction under the Controlled Substances Act, O.C.G.A. § 16-13-20 et seq.; however, circumstantial evidence was sufficient to authorize the jury's determination that Darvocet N-100 tablets defendant fraudulently obtained were the controlled substance dextropropoxyphene as alleged in the indictment. Hulsey v. State, 220 Ga. App. 64, 467 S.E. $2 \mathrm{~d} 610$ (1996).

CITED in Little v. State, 157 Ga. App. 462, 278 S.E.2d 17 (1981); Ward v. State, 248 Ga. 60, 281 S.E.2d 503 (1981); Castillo v. State, 166 Ga. App. 817, 305 S.E.2d 629 (1983); Davis v. 
State, 232 Ga. App. 882, 502 S.E.2d 779 (1998); Williams v. State, 279 Ga. App. 83, 630 S.E.2d 601 (2006).

\section{RESEARCH REFERENCES}

AM. JUR. 2D. --25 Am. Jur. 2d, Drugs and Controlled Substances, $\S 8$.

C.J.S. --28 C.J.S., Drugs and Narcotics, §§ 30, 119, 122.

U.L.A. --Uniform Controlled Substances Act (U.L.A.) $§ 210$.

TITLE 16. CRIMES AND OFFENSES

CHAPTER 13. CONTROLLED SUBSTANCES

ARTICLE 2. REGULATION OF CONTROLLED SUBSTANCES

O.C.G.A. § 16-13-29 (2007)

$\S 16-13-29$. Schedule V

The controlled substances listed in this Code section are included in Schedule V:

(1) Any compound, mixture, or preparation containing limited quantities of any of the following narcotic drugs, or salts thereof, which also contains one or more nonnarcotic, active, medicinal ingredients in sufficient proportion to confer upon the compound, mixture, or preparation valuable medicinal qualities other than those possessed by the narcotic drug alone:

(A) Not more than 200 milligrams of codeine, or any of its salts, per 100 milliliters or per 100 grams;

(B) Not more than 100 milligrams of dihydrocodeine, or any of its salts, per 100 milliliters or per 100 grams;

(C) Not more than 100 milligrams of ethylmorphine, or any of its salts, per 100 milliliters or per 100 grams;

(D) Not more than 2.5 milligrams of diphenoxylate and not less than 25 micrograms of atropine sulfate per dosage unit;

(E) Not more than 100 milligrams of opium per 100 milliliters or per 100 grams;

(2) Reserved;

(3) Pregabalin; or

(4) Pyrovalerone.

HISTORY: Code 1933, § 79A-810, enacted by Ga. L. 1974, p. 221, § 1; Ga. L. 1978, p. 1668, § 9; Ga. L. 1979, p. 859, § 9; Ga. L. 1980, p. 1746, § 8; Ga. L. 1981, p. 557, § 5; Ga. L. 1984, p. 1019, § 2; Ga. L. 1986, p. 1555, § 5; Ga. L. 1989, p. 233, § 5; Ga. L. 1993, p. 590, § 3; Ga. L. 2003, p. 349, § 5; Ga. L. 2007, p. 605, § 2/HB 286.

\section{NOTES:}

THE 2007 AMENDMENT, effective May 29, 2007, substituted "Pregabalin" for "Reserved" in paragraph (3). 
CODE COMMISSION NOTES. --Pursuant to Code Section 28-9-5, in 2003, a semicolon was substituted for a period at the end of paragraph (2).

ADMINISTRATIVE RULES AND REGULATIONS. --Definition of narcotic drug, Official Compilation of Rules and Regulations of State of Georgia, Rules of Georgia State Board of Pharmacy, Chapter 480-17. Exemptions from Georgia Controlled Substances Act, Official Compilation of Rules and Regulations of State of Georgia, Rules of Georgia State Board of Pharmacy, Chapter 480-17. Requirements of a prescription drug order, Official Compilation of Rules and Regulations of State of Georgia, Rules of Georgia State Board of Pharmacy, Chapter 480-22.

\section{JUDICIAL DECISIONS}

CITED in Taylor v. State, 144 Ga. App. 534, 241 S.E.2d 590 (1978); Little v. State, 157 Ga. App. 462, 278 S.E.2d 17 (1981); Printup v. State, 159 Ga. App. 574, 284 S.E.2d 82 (1981).

\section{RESEARCH REFERENCES}

AM. JUR. 2D. --25 Am. Jur. 2d, Drugs and Controlled Substances, $\S 8$.

C.J.S. --28 C.J.S., Drugs and Narcotics, $\S \S 122,173,174$.

U.L.A. --Uniform Controlled Substances Act (U.L.A.) § 212.

TITLE 16. CRIMES AND OFFENSES

CHAPTER 13. CONTROLLED SUBSTANCES

ARTICLE 2. REGULATION OF CONTROLLED SUBSTANCES

O.C.G.A. § 16-13-29.1 (2007)

$\S 16-13-29.1$. Nonnarcotic substances excluded from schedules of controlled substances

The following nonnarcotic substances which may, under the Federal Food, Drug, and Cosmetic Act (21 U.S.C. 301), be lawfully sold over the counter without a prescription, are excluded from all schedules of controlled substances under this article:

Trade name or

designation

(Dosage form) Composition/Potency Manufacturer or Distributor

$\begin{array}{lll}\begin{array}{c}\text { Amodrine } \\ \text { (Tablet) }\end{array} & \begin{array}{l}\text { Phenobarbital } / 8.00 \mathrm{mg} ; \\ \text { Aminophylline } / 100.00 \mathrm{mg} ;\end{array} & \text { Searle, G.D. \& Co } \\ \begin{array}{c}\text { Racephedrine } / 25.00 \mathrm{mg} \\ \text { (Enteric- }\end{array} & \begin{array}{l}\text { Phenobarbital } / 8.00 \mathrm{mg} ; \\ \text { Aminophylline } / 100.00 \mathrm{mg} ;\end{array} & \text { Searle, G.D. \& Co. } \\ \begin{array}{c}\text { Roated } \\ \text { tablet) }\end{array} & \text { Racephedrine } / 25.00 \mathrm{mg} & \\ \begin{array}{c}\text { Anodyne } \\ \text { Anti-Asthment) }\end{array} & \text { Chloral hydrate } / 0.69 \mathrm{~g} / 30 \mathrm{~g} & \text { Zemmer Co. }\end{array}$




\begin{tabular}{|c|c|c|}
\hline (Tablet) & $\begin{array}{l}\text { Theophylline/130.00 mg; } \\
\text { Ephedrine hydrochloride/ } \\
25.00 \mathrm{mg}\end{array}$ & \\
\hline $\begin{array}{l}\text { Anti-asthmatic } \\
\text { (Tablet) }\end{array}$ & $\begin{array}{l}\text { Phenobarbital/ } 8.10 \mathrm{mg} \text {; } \\
\text { Ephedrine hydrochloride/ } \\
24.00 \mathrm{mg} \text {; Theophylline/ } \\
130.00 \mathrm{mg}\end{array}$ & Zenith Labs., Inc. \\
\hline $\begin{array}{l}\text { Asma-Ese } \\
\text { (Tablet) }\end{array}$ & $\begin{array}{l}\text { Phenobarbital } / 8.10 \mathrm{mg} \text {; } \\
\text { Theophylline } / 129.60 \mathrm{mg} \text {; } \\
\text { Ephedrine hydrochloride/ } \\
24.30 \mathrm{mg}\end{array}$ & Parmed Pharm. \\
\hline $\begin{array}{l}\text { Asma-Lief } \\
\text { (Tablet) }\end{array}$ & $\begin{array}{l}\text { Phenobarbital/ } 8.10 \mathrm{mg} \text {; } \\
\text { Ephedrine hydrochloride/ } \\
24.30 \mathrm{mg} \text {; Theophylline/ } \\
129.60 \mathrm{mg}\end{array}$ & Columbia Medical Co. \\
\hline $\begin{array}{l}\text { Asma-Lief } \\
\text { Pediatric } \\
\text { (Suspension) }\end{array}$ & $\begin{array}{l}\text { Phenobarbital } / 4.00 \mathrm{mg} / 05 \mathrm{ml} \text {; } \\
\text { Ephedrine hydrochloride/ } \\
12.00 \mathrm{mg} / 05 \mathrm{ml} \text {; } \\
\text { Theophylline } / 65.00 \\
\mathrm{mg} / 05 \mathrm{ml}\end{array}$ & Columbia Medical Co. \\
\hline $\begin{array}{l}\text { Asma Tuss } \\
\text { (Syrup) }\end{array}$ & $\begin{array}{l}\text { Phenobarbital } / 4.00 \mathrm{mg} / 05 \mathrm{ml} \text {; } \\
\text { Glyceryl guaiacolate } / 50.00 \\
\mathrm{mg} / 05 \mathrm{ml} \text {; Chlorphentramine } \\
\text { maleate } 1.00 \mathrm{mg} / 05 \mathrm{ml} ; \\
\text { Ephedrine sulfate } / 12.00 \\
\mathrm{mg} / 05 \mathrm{ml} \text {; Theophylline/ } \\
15.00 \mathrm{mg} / 05 \mathrm{ml}\end{array}$ & Halsey Drug Co. \\
\hline $\begin{array}{l}\text { Azma-Aid } \\
\text { (Tablet) }\end{array}$ & $\begin{array}{l}\text { Phenobarbital } / 8.00 \mathrm{mg} \text {; } \\
\text { Theophylline/129.60 mg } \\
\text { Ephedrine hydrochloride/ } \\
24.30 \mathrm{mg}\end{array}$ & Rondex Labs. \\
\hline $\begin{array}{l}\text { Azmadrine } \\
\text { (Tablet) }\end{array}$ & $\begin{array}{l}\text { Phenobarbital/ } 8.00 \mathrm{mg} \text {; } \\
\text { Ephedrine hydrochloride/ } \\
24.00 \mathrm{mg} \text {; Theophylline/ } \\
130.00 \mathrm{mg}\end{array}$ & U.S. Ethicals \\
\hline $\begin{array}{l}\text { Benzedrex } \\
\text { Inhaler } \\
\text { (Inhaler) }\end{array}$ & Propylhexedrine & $\begin{array}{l}\text { Smith Kline } \\
\text { Consumer } \\
\text { Products }\end{array}$ \\
\hline $\begin{array}{l}\text { Bet-U-Lol } \\
\text { (Liquid) }\end{array}$ & $\begin{array}{l}\text { Chloral hydrate } / 0.54 \mathrm{~g} / 30 \mathrm{ml} \text {; } \\
\text { Methyl salicylate/ } \\
30.10 \mathrm{~g} / 30 \mathrm{ml} \text {; Menthol/ } \\
0.69 \mathrm{~g} / 30 \mathrm{ml}\end{array}$ & Huxley Pharm. \\
\hline $\begin{array}{l}\text { Bronkolixir } \\
\text { (Elixir) }\end{array}$ & $\begin{array}{l}\text { Phenobarbital } / 4.00 \mathrm{mg} / 05 \mathrm{ml} \text {; } \\
\text { Theophylline } / 15.00 \mathrm{mg} / 05 \mathrm{ml} \text {; } \\
\text { Ephedrine sulfate } / 12.00 \\
\mathrm{mg} / 05 \mathrm{ml} \text {; Glyceryl }\end{array}$ & Breon Labs. \\
\hline
\end{tabular}




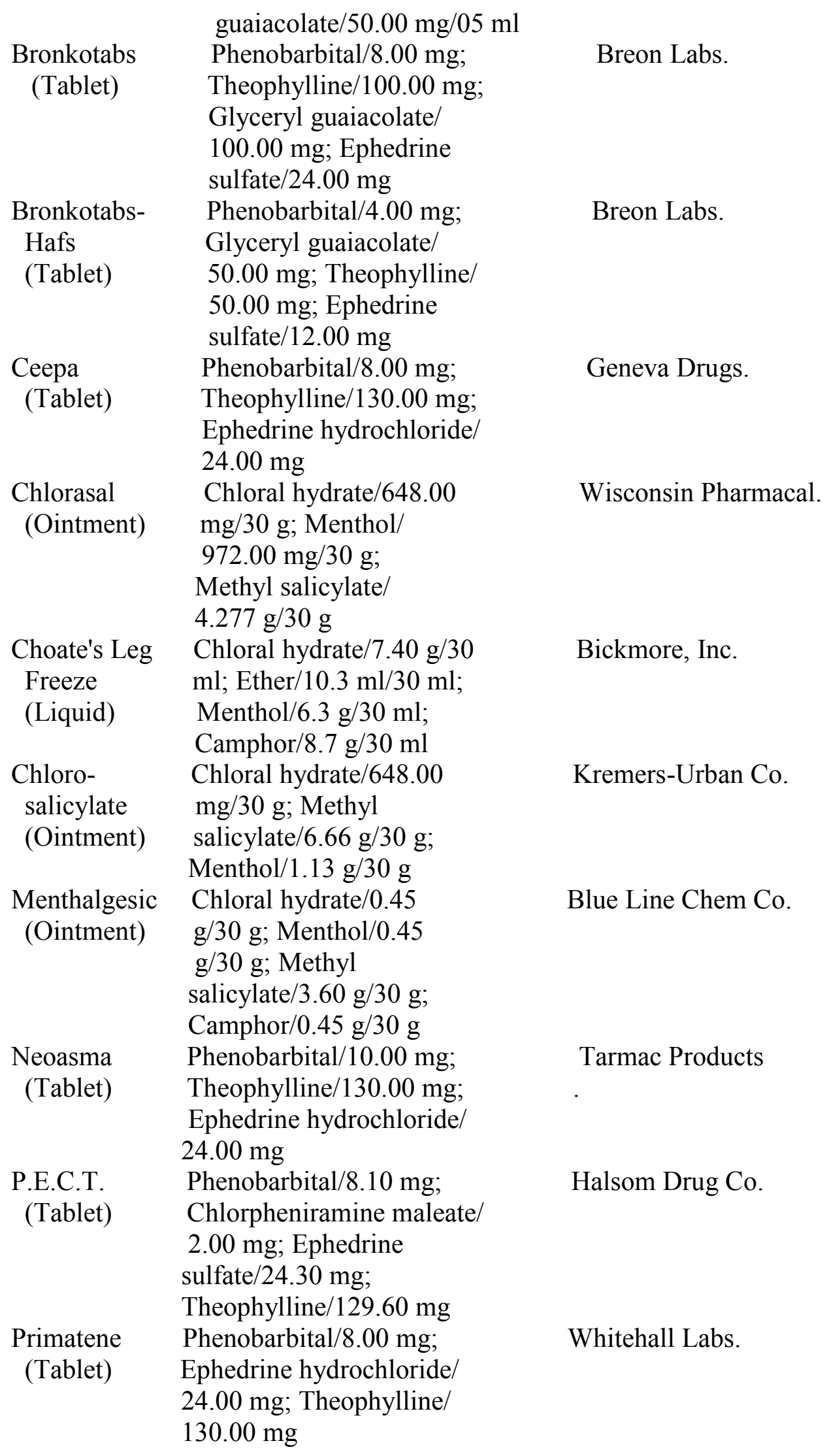




\begin{tabular}{|c|c|c|}
\hline $\begin{array}{l}\text { Rynal } \\
\text { (Spray) }\end{array}$ & $\begin{array}{l}\text { d1-methamphetamine } \\
\text { hydrochloride } / 0.11 \\
\mathrm{~g} / 50 \mathrm{ml} \text {; Antipyrine/ } \\
0.14 \mathrm{~g} / 50 \mathrm{ml} \text {; Pyriamine } \\
\text { maleate } / 0.005 \mathrm{~g} / 50 \mathrm{ml} ; \\
\text { Hyamine } 2389 / 0.01 \mathrm{~g} / 50 \mathrm{ml}\end{array}$ & Blaine Co. \\
\hline $\begin{array}{l}\text { S-K Asthma } \\
\text { (Tablet) }\end{array}$ & $\begin{array}{l}\text { Phenobarbital/ } 8.00 \mathrm{mg} \text {; } \\
\text { Ephedrine hydrochloride/ } \\
24.30 \mathrm{mg} \text {; Theophylline/ } \\
129.60 \mathrm{mg}\end{array}$ & S-K Research Labs. \\
\hline $\begin{array}{l}\text { Tedral } \\
\text { (Tablet) }\end{array}$ & $\begin{array}{l}\text { Phenobarbital/ } 8.00 \mathrm{mg} \text {; } \\
\text { Theophylline/ } 130.00 \mathrm{mg} \text {; } \\
\text { Ephedrine hydrochloride/ } \\
24.00 \mathrm{mg}\end{array}$ & Warner- Chilcott. \\
\hline $\begin{array}{l}\text { Tedral } \\
\text { Anti H } \\
\text { (Tablet) }\end{array}$ & $\begin{array}{l}\text { Phenobarbital/ } 8.00 \mathrm{mg} \text {; } \\
\text { Chlorpheniramine maleate/ } \\
2.00 \mathrm{mg} \text {; Theophylline/ } \\
130.00 \mathrm{mg} \text {; Ephedrine } \\
\text { hydrochloride/ } 24.00 \mathrm{mg}\end{array}$ & Warner- Chilcott. \\
\hline $\begin{array}{l}\text { Tedral } \\
\text { Antiasthmatic } \\
\text { (Tablet) }\end{array}$ & $\begin{array}{l}\text { Phenobarbital } / 8.00 \mathrm{mg} \text {; } \\
\text { Theophylline } / 130.00 \mathrm{mg} \text {; } \\
\text { Ephedrine hydrochloride/ } \\
24.00 \mathrm{mg}\end{array}$ & Parke-Davis \& Co. \\
\hline $\begin{array}{l}\text { Tedral Elixir } \\
\text { (Elixir) }\end{array}$ & $\begin{array}{l}\text { Phenobarbital/2.00 mg/05 } \\
\text { ml; Ephedrine hydro- } \\
\text { chloride/ } 6.00 \mathrm{mg} / 05 \mathrm{ml} \text {; } \\
\text { Theophylline } / 32.50 \mathrm{mg} / \\
05 \mathrm{ml}\end{array}$ & Warner- Chilcott. \\
\hline $\begin{array}{l}\text { Tedral } \\
\text { Pediatric } \\
\text { (Suspension) }\end{array}$ & $\begin{array}{l}\text { Phenobarbital/4.00 mg/05 } \\
\text { ml; Ephedrine hydro- } \\
\text { chloride/ } 12.00 \mathrm{mg} / 05 \\
\mathrm{ml} \text {; Theophylline/65.00 } \\
\mathrm{mg} / 05 \mathrm{ml}\end{array}$ & Warner- Chilcott. \\
\hline $\begin{array}{l}\text { Teephen } \\
\text { (Tablet) }\end{array}$ & $\begin{array}{l}\text { Phenobarbital/ } 8.00 \mathrm{mg} \text {; } \\
\text { Ephedrine hydrochloride/ } \\
24.00 \mathrm{mg} \text {; Theophylline/ } \\
130.00 \mathrm{mg}\end{array}$ & Robinson Labs. \\
\hline $\begin{array}{l}\text { Teephen } \\
\text { Pediatric } \\
\text { (Suspension) }\end{array}$ & $\begin{array}{l}\text { Phenobarbital/ } 4.00 \mathrm{mg} / 05 \\
\text { ml; Ephedrine hydro- } \\
\text { chloride/ } 12.00 \mathrm{mg} / 05 \mathrm{ml} \text {; } \\
\text { Theophylline anhydrous/ } \\
65.00 \mathrm{mg} / 05 \mathrm{ml}\end{array}$ & Robinson Labs. \\
\hline $\begin{array}{l}\text { TEP } \\
\text { (Tablet) }\end{array}$ & $\begin{array}{l}\text { Phenobarbital/ } 8.00 \mathrm{mg} \text {; } \\
\text { Theophylline } 130.00 \mathrm{mg} \text {; } \\
\text { Ephedrine hydrochloride/ } \\
24.00 \mathrm{mg}\end{array}$ & Towne, Paulsen \& Co., Inc. \\
\hline
\end{tabular}




\begin{tabular}{|c|c|c|}
\hline $\begin{array}{l}\text { T.E.P. } \\
\text { Compound } \\
\text { (Tablet) }\end{array}$ & $\begin{array}{l}\text { Phenobarbital/ } 8.10 \mathrm{mg} \text {; } \\
\text { Theophylline/129.60 mg; } \\
\text { Ephedrine hydrochloride/ } \\
24.30 \mathrm{mg}\end{array}$ & Stanlabs, Inc. \\
\hline $\begin{array}{l}\text { Thedrizem } \\
\text { (Tablet) }\end{array}$ & $\begin{array}{l}\text { Phenobarbital/ } 8.00 \mathrm{mg} \text {; } \\
\text { Ephedrine hydrochloride/ } \\
25.00 \mathrm{mg} \text {; Theophylline/ } \\
100.00 \mathrm{mg}\end{array}$ & Zemmer Co. \\
\hline $\begin{array}{l}\text { Theobal } \\
\text { (Tablet) }\end{array}$ & $\begin{array}{l}\text { Phenobarbital/ } 8.00 \mathrm{mg} \text {; } \\
\text { Ephedrine hydrochloride/ } \\
24.00 \mathrm{mg} \text {; Theophylline/ } \\
130.00 \mathrm{mg}\end{array}$ & Halsey Drug Co. \\
\hline $\begin{array}{l}\text { Val-Tep } \\
\text { (Tablet) }\end{array}$ & $\begin{array}{l}\text { Phenobarbital/ } 8.00 \mathrm{mg} \text {; } \\
\text { Ephedrine hydrochloride/ } \\
24.00 \mathrm{mg} \text {; Theophylline/ } \\
130.00 \mathrm{mg}\end{array}$ & Vale Chemical Co. \\
\hline $\begin{array}{l}\text { Verequad } \\
\text { (Suspension) }\end{array}$ & $\begin{array}{l}\text { Phenobarbital } / 4.00 \mathrm{mg} / 05 \mathrm{ml} \text {; } \\
\text { Ephedrine hydrochloride/ } \\
12.00 \mathrm{mg} / 05 \mathrm{ml} \text {; } \\
\text { Theophylline calcium } \\
\text { salicylate } / 65.00 \mathrm{mg} / 05 \mathrm{ml} \text {; } \\
\text { Glyceryl guaiacolate/ } \\
50.00 \mathrm{mg} / 05 \mathrm{ml}\end{array}$ & Knoll Pharm. \\
\hline $\begin{array}{l}\text { Verequad } \\
\text { (Tablet) }\end{array}$ & $\begin{array}{l}\text { Phenobarbital } / 8.00 \mathrm{mg} \text {; } \\
\text { Ephedrine hydrochloride/ } \\
24.00 \mathrm{mg} \text {; Glyceryl } \\
\text { guaiacolate } / 100.00 \mathrm{mg} \text {; } \\
\text { Theophylline calcium } \\
\text { salicylate/130.00 mg }\end{array}$ & Knoll Pharm. \\
\hline $\begin{array}{l}\text { Vicks Inhaler } \\
\text { (Inhaler) }\end{array}$ & 1-Desoxyephedrine/113.00 mg & Vicks Chemical Co \\
\hline
\end{tabular}

HISTORY: Code 1981, § 16-13-29.1, enacted by Ga. L. 1983, p. 349, § 1; Ga. L. 1989, p. 233, § 6; Ga. L. 1990, p. 8, § 16.

TITLE 16. CRIMES AND OFFENSES CHAPTER 13. CONTROLLED SUBSTANCES ARTICLE 2. REGULATION OF CONTROLLED SUBSTANCES O.C.G.A. § 16-13-29.2 (2007)

$\S 16-13-29.2$. Authority for exemption of over-the-counter Schedule V controlled substances

The Georgia State Board of Pharmacy shall have the authority to exempt and control the sale of Schedule V controlled substances by rule which shall allow the sale of such substances without the need for issuance of a prescription from a medical practitioner and shall require such substances to be sold only in a pharmacy when such substances are sold without a prescription. 
Such substances shall be known as Exempt Over-the-Counter (OTC) Schedule V Controlled Substances.

HISTORY: Code 1981, § 16-13-29.2, enacted by Ga. L. 2003, p. 349, § 6. 


\section{Illinois}

\section{Drug Specifics}

Intoxicating compounds, other drugs, cannabis, and controlled substances. 


\section{Indiana}

\section{Drug Specifics}

Controlled substances listed in schedules I and II of Section 35-48-2, and drugs other than alcohol or controlled substances.

\section{5-48-2-4. Schedule I.}

(a) The controlled substances listed in this section are included in schedule I.

(b) Opiates. Any of the following opiates, including their isomers, esters, ethers, salts, and salts of isomers, esters, and ethers, unless specifically excepted by rule of the board or unless listed in another schedule, whenever the existence of these isomers, esters, ethers, and salts is possible within the specific chemical designation:

Acetylmethadol (9601)

Allylprodine (9602)

Alphacetylmethadol (9603)

Alphameprodine (9604)

Alphamethadol (9605)

Alphamethylfentanyl (9614)

Benzethidine (9606)

Betacetylmethadol (9607)

Betameprodine (9608)

Betamethadol (9609)

Betaprodine (9611)

Clonitazene (9612)

Dextromoramide (9613)

Diampromide (9615)

Diethylthiambutene (9616)

Difenoxin (9168)

Dimenoxadol (9617)

Dimepheptanol (9618)

Dimethylthiambutene (9619)

Dioxaphetyl butyrate (9621)

Dipipanone (9622)

Ethylmethylthiambutene (9623)

Etonitazene (9624)

Etoxeridine (9625)

Furethidine (9626)

Hydroxypethidine (9627)

Ketobemidone (9628)

Levomoramide (9629)

Levophenacylmorphan (9631)

3-Methylfentanyl [N-[3-methyl-1-(2-phenylethyl)-4-piperidyl]-N-phenyl-propanimid e] (9813)

MPPP (1-methyl-4-phenyl-4-propionoxypiperidine) (9961)

Morpheridine (9632)

Noracymethadol (9633)

Norlevorphanol (9634) 
Normethadone (9635)

Norpipanone (9636)

Phenadoxone (9637)

Phenampromide (9638)

Phenomorphan (9647)

Phenoperidine (9641)

PEPAP [1-(2-phenethyl)-4-phenyl-4-acetoxypiperidine] (9663)

Piritramide (9642)

Proheptazine (9643)

Properidine (9644)

Propiram (9649)

Racemoramide (9645)

Tilidine (9750)

Trimeperidine (9646)

(c) Opium derivatives. Any of the following opium derivatives, their salts, isomers, and salts of isomers, unless specifically excepted by rule of the board or unless listed in another schedule, whenever the existence of these salts, isomers, and salts of isomers is possible within the specific chemical designation:

Acetorphine (9319)

Acetyldihydrocodeine (9051)

Benzylmorphine (9052)

Codeine methylbromide (9070)

Codeine-N-Oxide (9053)

Cyprenorphine (9054)

Desomorphine (9055)

Dihydromorphine (9145)

Drotebanol (9335)

Etorphine (except hydrochloride salt) (9056)

Heroin (9200)

Hydromorphinol (9301)

Methyldesorphine (9302)

Methyldihydromorphine (9304)

Morphine methylbromide (9305)

Morphine methylsulfonate (9306)

Morphine-N-Oxide (9307)

Myrophine (9308)

Nicocodeine (9309)

Nicomorphine (9312)

Normorphine (9313)

Pholcodine (9314)

Thebacon (9315)

(d) Hallucinogenic substances. Any material, compound, mixture, or preparation which contains any quantity of the following hallucinogenic, psychedelic, or psychogenic substances, their salts, isomers, and salts of isomers, unless specifically excepted by rule of the board or unless listed in another schedule, whenever the existence of these salts, isomers, and salts of isomers is possible within the specific chemical designation: 
(1) 4-Bromo-2, 5-Dimethoxyamphetamine (7391). Some trade or other names: 4-Bromo2, 5-Dimethoxy-a-methylphenethylamine; 4-Bromo-2, 5-DMA.

(2) 2, 5-Dimethoxyamphetamine (7396). Some trade or other names: 2, 5-Dimethoxy-amethylphenethylamine; 2, 5-DMA.

(3) 4-Methoxyamphetamine (7411). Some trade or other names: 4-Methoxy-amethylphenethylamine; Paramethoxyamphetamine; PMA.

(4) 5-methoxy-3, 4-methylenedioxy amphetamine (7401). Other Name: MMDA.

(5) 4-methyl-2, 5-dimethoxyamphetamine (7395). Some trade and other names: 4methyl-2, 5-dimethoxy-a-methylphenethylamine; DOM; and STP.

(6) 3, 4-methylenedioxy amphetamine (7400). Other name: MDA.

(7) 3, 4-methylenedioxymethamphetamine (MDMA) (7405).

(8) 3, 4, 5-trimethoxy amphetamine (7390). Other name: TMA.

(9) Bufotenine (7433). Some trade and other names: 3-(B-Dimethylaminoethyl)-5hydroxyindole; 3-(2-dimethylaminonethyl)-5-indolol; N, N-dimethylserotonin; 5hydroxy-N, N-dimethyltryptamine; mappine.

(10) Dimethyltryptamine (7434). Some trade or other names: N, N-Diethyltryptamine; DET.

(11) Diethyltryptamine (7435). Some trade or other names: DMT.

(12) Ibogaine (7260). Some trade and other names: 7-Ethyl-6, 6b, 7, 8, 9, 10, 12, 13octahydro-2-methoxy-6, 9-methano-5H-pyrido (1', 2': 1, 2, azepino 4, 5-b) indole; tabernanthe iboga.

(13) Lysergic acid diethylamide (7315). Other name: LSD.

(14) Marijuana (7360).

(15) Mescaline (7381).

(16) Parahexyl (7374). Some trade or other names: 3-Hexyl-1-hydroxy-7, 8, 9, 10-

Tetrahydro-6, 6, 9-trimethyl-6H-dibenzo (b,d) pyran; Snyhexyl.

(17) Peyote (7415), including:

(A) all parts of the plant that are classified botanically as lophophora williamsii lemaire, whether growing or not;

(B) the seeds thereof;

(C) any extract from any part of the plant; and

(D) every compound, manufacture, salt, derivative, mixture, or preparation of the plant, its seeds, or extracts.

(18) N-ethyl-3-piperidyl benzilate (7482). Other name: DMZ.

(19) N-methyl-3-piperidyl benzilate (7484). Other name: LBJ.

(20) Psilocybin (7437).

(21) Psilocyn (7438).

(22) Tetrahydrocannabinols (7370), including synthetic equivalents of the substances contained in the plant, or in the resinous extractives of Cannabis and synthetic substances, derivatives, and their isomers with similar chemical structure and pharmacological activity such as:

(A) [1] cis or trans tetrahydrocannabinol, and their optical isomers;

(B) [6] cis or trans tetrahydrocannabinol, and their optical isomers; and

(C) [3,][4] cis or trans tetrahydrocannabinol, and their optical isomers. 
Since nomenclature of these substances is not internationally standardized, compounds of these structures, regardless of numerical designation of atomic positions are covered. Other name: THC.

(23) Ethylamine analog of phencyclidine (7455). Some trade or other names: N-Ethyl1-phenylcyclohexylamine; (1-phenylcyclohexyl) ethylamine; N-(1-phenylcyclohexyl) ethylamine; cyclohexamine; PCE.

(24) Pyrrolidine analog of phencyclidine (7458). Some trade or other names: 1-(1phenylcyclohexyl)-pyrrolidine; PCP[y]; PHP.

(25) Thiophene analog of phencyclidine (7470). Some trade or other names: 1-(1-(2thienyl) cyclohexyl) piperidine; 2-Thienyl Analog of Phencyclidine; TPCP.

(e) Depressants. Unless specifically excepted in a rule adopted by the board or unless listed in another schedule, any material, compound, mixture, or preparation which contains any quantity of the following substances having a depressant effect on the central nervous system, including its salts, isomers, and salts of isomers whenever the existence of such salts, isomers, and salts of isomers is possible within the specific chemical designation:

Gamma-hydroxybutyric acid (other names include GHB; gamma-hydroxybutyrate; 4hydroxybutanoic acid; sodium oxybate; sodium oxybutyrate) (2010)

Mecloqualone (2572)

Methaqualone (2565)

(f) Stimulants. Unless specifically excepted or unless listed in another schedule, any material, compound, mixture, or preparation that contains any quantity of the following substances having a stimulant effect on the central nervous system, including its salts, isomers, and salts of isomers: Fenethylline (1503) N-ethylamphetamine (1475)

Methcathinone (1237) (Some other trade names: 2-Methylamino-1-Phenylpropan-I-one; Ephedrone; Monomethylpropion; UR 1431[)].

Schedule II.

(a) The controlled substances listed in this section are included in schedule II.

(b) Any of the following substances, except those narcotic drugs listed in other schedules, whether produced directly or indirectly by extraction from substances of vegetable origin, or independently by means of chemical synthesis, or by combination of extraction and chemical synthesis:

(1) Opium and opiate, and any salt, compound, derivative, or preparation of opium or opiate, excluding apomorphine, dextrorphan, nalbuphine, naloxone, naltrexone, and their respective salts but including:

(A) raw opium (9600);

(B) opium extracts (9610);

(C) opium fluid extracts (9620);

(D) powdered opium (9639);

(E) granulated opium (9640);

(F) tincture of opium (9630);

(G) codeine (9050);

(H) ethylmorphine (9190);

(I) etorphine hydrochloride (9059);

(J) hydrocodone (9193);

(K) hydromorphone (9150); 
(L) metopon (9260);

(M) morphine (9300);

(N) oxycodone (9143);

(O) oxymorphone (9652); and

(P) thebaine (9333).

(2) Any salt, compound, isomer, derivative, or preparation thereof which is chemically equivalent or identical with any of the substances referred to in subdivision (b) (1) of this section, but not including the isoquinoline alkaloids of opium.

(3) Opium poppy and poppy straw.

(4) Cocaine (9041).

(5) Concentrate of poppy straw (the crude extract of poppy straw in either liquid, solid, or powder form which contains the phenanthrene alkaloids of the opium poppy) (9670).

(c) Opiates. Any of the following opiates, including their isomers, esters, ethers, salts, and salts of isomers, esters, and ethers whenever the existence of these isomers, esters, ethers, and salts is possible within the specific chemical designation:

Alfentanil (9737)

Alphaprodine (9010)

Anileridine (9020)

Bezitramide (9800)

Bulk dextropropoxyphene (nondosage forms) (9273)

Dihydrocodeine (9120)

Diphenoxylate (9170)

Fentanyl (9801)

Isomethadone (9226)

Levomethorphan (9210)

Levorphanol (9220)

Metazocine (9240)

Methadone (9250)

Methadone-Intermediate, 4-cyano-2-dimethyl-amino-4, 4-diphenyl butane (9254)

Moramide-Intermediate, 2-methyl-3-morpholino-1, 1-diphenylpropane-carboxylic acid (9802)

Pethidine (Meperidine) (9230)

Pethidine-Intermediate- A, 4-cyano-1-methyl-4-phenylpiperidine (9232)

Pethidine-Intermediate-B, ethyl-4-phenylpiperidine-4-carboxylate (9233)

Pethidine-Intermediate-C,1-methyl-4-phenylpiperidine-4-carbo xylic acid (9234)

Phenazodine (9715)

Piminodine (9730)

Racemethorphan (9732)

Racemorphan (9733)

Sufentanil (9740)

(d) Stimulants. Any material compound, mixture, or preparation which contains any quantity of the following substances having a potential for abuse associated with a stimulant effect on the central nervous system:

(1) Amphetamine, its salts, optical isomers, and salts of its optical isomers (1100).

(2) Methamphetamine, including its salts, isomers, and salts of its isomers (1105).

(3) Phenmetrazine and its salts (1631).

(4) Methylphenidate (1724). 
(e) Depressants. Unless specifically excepted by rule of the board or unless listed in another schedule, any material, compound, mixture, or preparation which contains any quantity of the following substances having a depressant effect on the central nervous system, including its salts, isomers, and salts of isomers whenever the existence of such salts, isomers, and salts of isomers is possible within the specific chemical designation:

Amobarbital (2125)

Gamma hydroxybutyrate

Pentobarbital (2270)

Phencyclidine (7471)

Secobarbital (2315)

(f) Immediate precursors. Unless specifically excepted by rule of the board or unless listed in another schedule, any material, compound, mixture, or preparation which contains any quantity of the following substances:

(1) Immediate precursor to amphetamine and methamphetamine: Phenylacetone (8501). Some trade or other names: phenyl-2-propanone; P2P; benzyl methyl ketone; methyl benzyl ketone.

(2) Immediate precursors to phencyclidine (PCP):

(A) 1-phenylcyclohexylamine (7460); or

(B) 1-piperidinocyclohexanecarbonitrile (PCC) (8603).

(g) Hallucinogenic substances:

Dronabinol (synthetic) in sesame oil and encapsulated in a soft gelatin capsule in a United

States Food and Drug Administration approved drug product (7369). 


\section{Minnesota \\ Drug Specifics}

When the person's body contains any amount of a controlled substance listed in schedule I or II other than marijuana or tetrahydrocannabinols. 


\section{Nevada}

\section{Drug Specifics}

Controlled substances, certain chemicals, poisons, organic solvents and compounds.

Prohibited Substance

(a) Amphetamine

(b) Cocaine

(c) Cocaine metabolite

(d) Heroin

(e) Heroin metabolite

(1) Morphine

(2) 6-monoacetyl Morphine

(f) Lysergic Acid Diethylamide

(g) Marijuana

(h) Marijuana Metabolite

(i) Methamphetamine

(j) Phencycladine
Urine

NG Per Milliliter

500

150

150

2,000

2,000

10

25

10

15

500

25

Blood
NG Per Milliliter
100
50
50
50

50
10
10
2
5
100
10




\section{Ohio}

\section{Drug Specifics}

Listed in law in report text. 


\section{Pennsylvania}

\section{Drug Specifics}

PENNSYLVANIA STATUTES

TITLE 35. HEALTH AND SAFETY

CHAPTER 6. THE CONTROLLED SUBSTANCE, DRUG, DEVICE AND COSMETIC ACT

35 P.S. $\S 780-104(2007)$

$\S 780-104$. Schedules of controlled substances

The following schedules include the controlled substances listed or to be listed by whatever official name, common or usual name, chemical name, or trade name designated

(1) SCHEDULE I-- In determining that a substance comes within this schedule, the secretary shall find: a high potential for abuse, no currently accepted medical use in the United States, and a lack of accepted safety for use under medical supervision. The following controlled substances are included in this schedule:

(i) Any of the following opiates, including their isomers, esters, ethers, salts, and salts of isomers, esters, and ethers, unless specifically excepted, whenever the existence of such isomers, esters, ethers and salts is possible within the specific chemical designation:

1. Acetylmethadol.

2. Allylprodine.

3. Alphacetylmethadol.

4. Alphameprodine.

5. Alphamethadol.

6. Benzethidine.

7. Betacetylmethadol.

8. Betameprodine.

9. Betamethadol.

10. Betaprodine.

11. Clonitazene.

12. Dextromoramide.

13. Dextrorphan (except its methylether).

14. Diampromide.

15. Diethylthiambutene.

16. Dimenoxadol.

17. Dimepheptanol.

18. Dimethylthiambutene.

19. Dioxaphetyl butyrate.

20. Dipipanone.

21. Ethylmethylthiambutene.

22. Etonitazene.

23. Etoxeridine. 
24. Furethidine.

25. Hydroxypethidine.

26. Ketobemidone.

27. Levomoramide.

28. Levophenacylmorphan.

29. Morpheridine.

30. Noracymethadol.

31. Norlevorphanol.

32. Normethadone.

33. Norpipanone.

34. Phenadoxone.

35. Phenampromide.

36. Phenomorphan.

37. Phenoperidine.

38. Piritramide.

39. Proheptazine.

40. Properidine.

41. Racemoramide.

42. Trimeperidine.

(ii) Any of the following opium derivatives, their salts, isomers and salts of isomers, unless specifically excepted, whenever the existence of such salts, isomers and salts of isomers is possible within the specific chemical designation:

1. Acetorphine.

2. Acetyldihydrocodeine.

3. Benzylmorphine.

4. Codeine methylbromide.

5. Codeine-N-Oxide.

6. Cyprenorphine.

7. Desomorphine.

8. Dihydromorphine.

9. Etorphine.

10. Heroin.

11. Hydromorphinol.

12. Methyldesorphine.

13. Methylhydromorphine.

14. Morphine methylbromide.

15. Morphine methylsulfonate.

16. Morphine-N-Oxide.

17. Myrophine.

18. Nicocodeine.

19. Nicomorphine.

20. Normorphine.

21. Pholcodine. 
22. Thebacon.

(iii) Any material, compound, mixture, or preparation which contains any quantity of the following hallucinogenic substances, their salts, isomers, and salts of isomers, unless specifically excepted, whenever the existence of such salts, isomers, and salts of isomers is possible within the specific chemical designation:

1. 3,4-methylenedioxy amphetamine.

2. 5-methoxy-3,4-methylenedioxy amphetamine.

3. 3,4,5-trimethoxy amphetamine.

4. Bufotenine.

5. Diethyltryptamine.

6. Dimethyltryptamine.

7. 4-methyl-2,5-dimethoxyamphetamine.

8. Ibogaine.

9. Lysergic acid diethylamide.

10. Mescaline.

11. Peyote.

12. N-ethyl-3-piperidyl benzilate.

13. N-methyl-3-piperidyl benzilate.

14. Psilocybin.

15. Psilocyn.

16. Tetrahydrocannabinols.

(iv) Marihuana.

(v) Any material, compound, mixture or preparation which contains any quantity of the following substances, including the salts, isomers and salts of isomers:

1. Methaqualone.

(vi) Gamma hydroxybutyric acid, any salt, hydroxybutyric compound, derivative or preparation of gamma hydroxybutyric acid, including any isomers, esters and ethers and salts of isomers, esters and ethers of gamma hydroxybutyric acid, except gamma-butyrolactone (GBL), whenever the existence of such isomers, esters and salts is possible within the specific chemical designation. For purposes of security requirements imposed by law or regulation upon registered distributors and registered manufacturers, this substance when manufactured, distributed or possessed in accordance with an exemption approved under section 505(i) of the Federal Food, Drug, and Cosmetic Act (52 Stat. 1040, 21

U.S.C. $\S 301$ et seq.) shall, notwithstanding any other provision of this act, be classified as a controlled substance in Schedule III of this section. 
(2) SCHEDULE II-- In determining that a substance comes within this schedule, the secretary shall find: a high potential for abuse, currently accepted medical use in the United States, or currently accepted medical use with severe restrictions, and abuse may lead to severe psychic or physical dependence. The following controlled substances are included in this schedule:

(i) Any of the following substances, of any quantity, except those narcotics specifically excepted or listed in other schedules, whether produced directly or indirectly by extraction from substances of vegetable origin, or independently by means of chemical synthesis, or

by combination of extraction and chemical synthesis:

1. Opium and opiate, and any salt, compound, derivative, or preparation of opium or opiate.

2. Any salt, compound, derivative, or preparation thereof which is chemically equivalent or identical with any of the substances referred to in subclause 1, except that these substances shall not include the isoquinoline alkaloids of opium.

3. Opium poppy and poppy straw.

4. Coca leaves and any salt, compound, derivative, or preparation of coca leaves, and any salt, compound, derivative, or preparation thereof which is chemically equivalent or identical with any of these substances, but shall not include decocainized coca leaves or extracts of coca leaves, which extracts do not contain cocaine or ecgonine.

(ii) Any of the following opiates, including their isomers, esters, ethers, salts, and salts of isomers, esters and ethers, of any quantity, unless specifically excepted or listed in another schedule, whenever the existence of such isomers, esters, ethers and salts is possible within the specific chemical designation:

1. Alphaprodine.

2. Anileridine.

3. Bezitramide.

4. Dihydrocodeine.

5. Diphenoxylate.

6. Fentanyl.

7. Isomethadone.

8. Levomethorphan.

9. Levorphanol.

10. Metazocine.

11. Methadone.

12. Methadone-Intermediate, 4-cyano-2-dimethylamino-4,

4-diphenylbutane.

13. Moramide-Intermediate, 2-methyl-3-morpholino-1, 1-diphenyl-propane-carboxylic acid.

14. Pethidine.

15. Pethidine-Intermediate-A, 4-cyano-1-methyl-4-phenylpiperidine. 
16. Pethidine-Intermediate-B, ethyl-4-phenylpiperidine-4-carboxylate.

17. Pethidine-Intermediate-C,

1-methyl-4-phenylpiperidine-4-carboxylic acid.

18. Phenazocine.

19. Piminodine.

20. Racemethorphan.

21. Racemorphan.

(iii) Unless specifically excepted or unless listed in another

schedule, any material, compound, mixture or preparation which contains

any quantity of the following substances:

1. Amphetamine, its salts, optical isomers, and salts of its optical

isomers.

2. Phenmetrazine and its salts.

3. Methylphenidate.

4. Methamphetamine including its salts, isomers and salts of isomers.

(iv) The phrase "opiates" as used in section 4 of this act and elsewhere throughout the act shall not include the dextrorotatory isomer of 3-methoxy-n-methylmorphinan and its salts, but does include its racemic and levorotatory forms.

(v) Any material, compound, mixture, or preparation unless specifically excepted which contains any quantity of:

1. Phencyclidine.

(3) SCHEDULE III-- In determining that a substance comes within this schedule, the secretary shall find: a potential for abuse less than the substances listed in Schedules I and II; well documented and currently accepted medical use in the United States; and abuse may lead to moderate or low physical dependence or high psychological dependence. The following classes of controlled substances are included in this schedule:

(i) Any material, compound, mixture, or preparation unless specifically excepted or unless listed in another schedule which contains any quantity of the following substances:

1. Any substance which contains any quantity of a derivative of barbituric acid, or any salt of a derivative of barbituric acid.

2. Chorhexadol.

3. Glutethimide.

4. Lysergic acid.

5. Lysergic acid amide.

6. Methyprylon.

7. Deleted by amendment. 1978 , Nov. 26, P.L. 1392 , No. 328 , § 1, effective in 60 days. 
8. Sulfondiethylmethane.

9. Sulfonethylmethane.

10. Sulfonmethane.

(ii) Nalorphine.

(iii) Any material, compound, mixture, or preparation containing limited quantities of the following narcotic drugs, or any salts thereof, unless specifically excepted or listed in other schedules:

1. Not more than 1.8 grams of codeine per 100 milliliters or not more than 90 milligrams per dosage unit, with an equal or greater quantity of an isoquinoline alkaloid of opium.

2. Not more than 1.8 grams of codeine per 100 milliliters or not more than 90 milligrams per dosage unit, with one or more active, nonnarcotic ingredients in recognized therapeutic amounts.

3. Not more than 300 milligrams of dihydrocodeinone per 100 milliliters or not more than 15 milligrams per dosage unit, with a fourfold or greater quantity of an isoquinoline alkaloid of opium.

4. Not more than 300 milligrams of dihydrocodeinone per 100 milliliters or not more than 15 milligrams per dosage unit, with one or more active, nonnarcotic ingredients in recognized therapeutic amounts.

5. Not more than 1.8 grams of dihydrocodeine per 100 milliliters or not more than 90 milligrams per dosage unit, with one or more active, nonnarcotic ingredients in recognized therapeutic amounts.

6. Not more than 300 milligrams of ethylmorphine per 100 milliliters or not more than 15 milligrams per dosage unit, with one or more active, nonnarcotic ingredients in recognized therapeutic amounts.

7. Not more than 500 milligrams of opium per 100 milliliters or per 100 grams, or not more than 25 milligrams per dosage unit, with one or more active, nonnarcotic ingredients in recognized therapeutic amounts.

8. Not more than 50 milligrams of morphine per 100 milliliters or per 100 grams and not more than 2.5 milligrams per dosage unit with one or more active, nonnarcotic ingredients in recognized therapeutic amounts.

(iv) [Not in original.]

(v) The secretary may by regulation except any compound, mixture, or preparation containing any drug or controlled substance listed in subclauses (i) and (ii) of this schedule above from the application of those provisions of this act covering controlled substances, if the compound, mixture, or preparation contains one or more active medicinal ingredients not having a stimulant 
or depressant effect on the central nervous system: Provided, That such admixtures shall be included therein in such combinations, quantity, proportion, or concentration as to vitiate the potential for abuse of the substances which do have a stimulant or depressant effect on the central nervous system.

(vi) The secretary shall by regulation exempt any nonnarcotic substance from the control under this act if such substance may, under the provisions of the Federal Food, Drug, and Cosmetic Act (21 U.S.C. 301 et seq.), be lawfully sold over the counter without a prescription.

(vii) Anabolic steroid includes any material, compound, mixture or preparation that includes any of the following or any isomer, ester, salt or derivative of any of the following that acts in the same manner on the human body:

1. Chorionic gonadotropin.

2. Clostebol.

3. Dehydrochlormethyltestosterone.

4. Ethylestrenol.

5. Fluoxymesterone.

6. Mesterolone.

7. Metenolone.

8. Methandienone.

9. Methandrostenolone.

10. Methyltestosterone.

11. Nandrolone decanoate.

12. Nandrolone phenpropionate.

13. Norethandrolone.

14. Oxandrolone.

15. Oxymesterone.

16. Oxymetholone.

17. Stanozolol.

18. Testosterone propionate.

19. Testosterone-like related compounds.

Human Growth Hormone (HGH) shall not be included as an anabolic steroid under the provisions of this act. An anabolic steroid which is a combination of estrogen and anabolic steroid and which is expressly intended for administration to hormone-deficient women shall be exempt from the provisions of this act. A person who prescribes, dispenses or distributes an anabolic steroid which is a combination of estrogen and anabolic steroids and which is intended for administration to hormone-deficient women for use by persons who are not hormonedeficient women shall be considered to have prescribed, dispensed or distributed an anabolic steroid within the meaning of this subclause.

(viii) Gamma hydroxybutyric acid, any salt, hydroxybutyric compound, derivative or preparation of gamma hydroxybutyric acid, including any isomers, esters and ethers and salts of isomers, esters and ethers of gamma hydroxybutyric acid, except gamma-butyrolactone (GBL), 
contained in a drug product for which an application has been approved under section 505 of the Federal Food, Drug, and Cosmetic Act.

(ix) Ketamine hydrochloride, any salt, ketamine hydrochloride compound, derivative or preparation of ketamine hydrochloride, including any isomers, esters and ethers and salts of isomers, esters and ethers of ketamine hydrochloride.

(4) SCHEDULE IV-- In determining that a substance comes within this schedule, the secretary shall find: a low potential for abuse relative to substances in Schedule III; currently accepted medical use in the United States; and limited physical and/or psychological dependence liability relative to the substances listed in Schedule III. The following controlled substances are included in this schedule:

(i) Any material, compound, mixture, or preparation, unless specifically excepted or unless listed in another schedule, which contains any quantity of the following substances:

1. Barbital.

2. Chloral betaine.

3. Chloral hydrate.

4. Ethchlorvynol.

5. Ethinamate.

6. Methohexital.

7. Meprobamate.

8. Methylphenobarbital.

9. Paraldehyde.

10. Petrichloral.

11. Phenobarbital.

(ii) The secretary may by regulation except any compound, mixture, or preparation containing any drug or controlled dangerous substance listed in subclause (i) of this schedule above from the application of those provisions of this act covering controlled drugs, if the compound, mixture, or preparation contains one or more active medicinal ingredients not having a stimulant or depressant effect on the central nervous system: Provided, That such admixtures shall be included therein in such combinations, quantity, proportion, or concentration as to vitiate the potential for abuse of the substances which do have a stimulant or depressant effect on the central nervous system.

(iii) The secretary shall by regulation exempt any nonnarcotic substance from the control under this act if such substance may, under the provisions of the Federal Food, Drug, and Cosmetic Act (21 U.S.C. 301 et seq.), be lawfully sold over the counter without a prescription.

(5) SCHEDULE V-- In determining that a substance comes within this schedule, the secretary shall find: a low potential for abuse relative to the substances listed in Schedule IV; currently accepted medical use in the United States; and limited physical dependence and/or psychological dependence liability relative to the substances listed in Schedule IV. The following controlled substances are included in this schedule: 
(i) Any compound, mixture, or preparation containing limited quantities of any of the following narcotics or any of their salts, which shall include one or more nonnarcotic active medicinal ingredients in sufficient proportion to confer upon the compound, mixture, or preparation, valuable medicinal qualities other than those possessed by the narcotic alone:

1. Not more than 200 milligrams of codeine, or any of its salts, per 100 milliliters or per 100 grams and not more than 10 milligrams per dosage unit.

2. Not more than 100 milligrams of dihydrocodeine, or any of its salts, per 100 milliliters or per 100 grams and not more than 5 milligrams per dosage unit.

3. Not more than 100 milligrams of ethylmorphine, or any of its salts, per 100 milliliters or per 100 grams and not more than 5 milligrams per dosage unit.

4. Not more than 2.5 milligrams of diphenoxylate and not less than 25 micrograms of atropine sulfate per dosage unit.

5. Not more than 100 milligrams of opium per 100 milliliters or per 100 grams, or not more than 5 milligrams per dosage unit.

(ii) Buprenorphine.

HISTORY: Act 1989-104 (H.B. 855), § 1, approved Dec. 22, 1989, eff. in 60 days; Act 1989-91 (S.B. 123), § 1, approved Dec. 22, 1989, eff. in 60 days; Act 1996-163 (S.B. 1662), § 1, approved Dec. 18, 1996, eff. in 60 days; Act 1999-55 (S.B. 798), § 1, approved Nov. 24, 1999, eff. in 60 days.; Act 2000-78 (S.B. 618), § 1, approved Oct. 18, 2000, eff. in 60 days.

NOTES:

PENNSYLVANIA ADMINISTRATIVE CODE REFERENCES.

1. $49 \mathrm{~Pa}$. Code $\S 33.207$ (2007), Prescribing, administering and dispensing controlled substances.

2. $28 \mathrm{~Pa}$. Code $\S 109.64$ (2007), Patients' own drugs.

3. $49 \mathrm{~Pa}$. Code $\S 18.158$ (2007), Prescribing and dispensing drugs, pharmaceutical aids and devices.

4. $28 \mathrm{~Pa}$. Code $\S 25.43$ (2007), Immediate writing required.

5. $28 \mathrm{~Pa}$. Code $\S 25.72$ (2007), Schedules of controlled substances.

LexisNexis (R) Notes:

CASE NOTES

1. Crack cocaine is a controlled substance within the meaning of 35 P.S. $\S 780-104(2)(i)(4)$. Commonwealth v. Dancy, 437 Pa. Super. 462, 650 A.2d 448, 1994 Pa. Super. LEXIS 3352 (1994), appeal denied by 540 Pa. 646, 659 A.2d 985 (1995). 
2. Modification of defendant's initial sentence of electronic monitoring was permitted on defendant's felony conviction of delivery of a controlled substance, cocaine, pursuant to 35 P.S. $\S 780-113$. The relevant sentencing statute, 18 Pa.C.S. $§ 7508$, required a mandatory minimum sentence of one year in prison for that offense and modification did not violate Apprendi, Blakely, Booker, the state constitution, or the federal constitution since 18 Pa.C.S. § 7508 dealt with mandatory minimum sentencing and not a trial court enhancing a sentence beyond the statutory maximum on facts not found by a jury. Commonwealth v. Slotcavage, 2007 Pa. Super. LEXIS 4141 (Dec. 13, 2007).

3. In defendant's trial for delivery of methamphetamine in violation of 35 P.S. § 780-104(2)(iii), the state was not required to show that the amount of methamphetamine delivered was sufficient to have a potential for abuse associated with the stimulant effect on the central nervous system; any quantity of methamphetamine, regardless of its potential for abuse, was sufficient for defendant to violate $\S 780-104(2)($ iii). Commonwealth v. Graeff, 296 Pa. Super. 480, 442 A.2d 1153, 1982 Pa. Super. LEXIS 3650 (1982).

4. Modification of defendant's initial sentence of electronic monitoring was permitted on defendant's felony conviction of delivery of a controlled substance, cocaine, pursuant to 35 P.S. $\S 780-113$. The relevant sentencing statute, 18 Pa.C.S. $\$ 7508$, required a mandatory minimum sentence of one year in prison for that offense and modification did not violate Apprendi, Blakely, Booker, the state constitution, or the federal constitution since 18 Pa.C.S. $§ 7508$ dealt with mandatory minimum sentencing and not a trial court enhancing a sentence beyond the statutory maximum on facts not found by a jury. Commonwealth v. Slotcavage, $2007 \mathrm{~Pa}$. Super. LEXIS 4141 (Dec. 13, 2007).

5. Terms of the Controlled Substance, Drug, Device and Cosmetic Act (DDC), 35 P.S. § 780104(2), make it clear that its prohibitory sweep is sufficiently wide so as to embrace those varieties of cocaine that are susceptible of synthetic derivation; the framers of the DDC intended to prohibit all varieties of cocaine including those that derive directly from coca leaves as well as those such as D-cocaine that are synthetically produced in a laboratory. Commonwealth v. Slyman, 334 Pa. Super. 415, 483 A.2d 519, 1984 Pa. Super. LEXIS 6052 (1984).

6. The contention of defendants convicted of possessing drugs with intention to deliver, that the commonwealth failed to prove that the particular kind of marijuana found at defendants' residence was of the kind prohibited by law, was without merit; the legislature embraced all species of the genus Cannabis sativa L. as forms of marijuana prohibited by 35 P.S. § 780104(1)(iv), Commonwealth v. Herman, 288 Pa. Super. 219, 431 A.2d 1016, 1981 Pa. Super. LEXIS 2945 (1981).

7. Reversal of defendant's conviction for possession, possession with intent to deliver, and delivery of a controlled substance in violation of 35 P.S. § 780-104(2)(iii) was required where the state failed to establish the quantity of amphetamine possessed, thus, the state failed to establish all of the essential elements of the offenses charged. Commonwealth v. Driscoll, 485 Pa. 99, 401 A.2d 312, 1979 Pa. LEXIS 536 (1979). 
8. 35 P.S. $§ 780-104(2)(i i i)$ proscribes the possession or delivery of one particular substance, methamphetamine, without regard to quantity. Commonwealth v. Teada, 235 Pa. Super. 438, 344 A.2d 682, 1975 Pa. Super. LEXIS 1636 (1975), questioned by United States v. Picklesimer, 585 F.2d 1199, 1978 U.S. App. LEXIS 7997 (3d Cir. Pa. 1978).

9. In defendant's trial for delivery of methamphetamine in violation of 35 P.S. $\S 780-104(2)(i i i)$, the state was not required to show that the amount of methamphetamine delivered was sufficient to have a potential for abuse associated with the stimulant effect on the central nervous system; any quantity of methamphetamine, regardless of its potential for abuse, was sufficient for defendant to violate $\S$ 780-104(2)(iii). Commonwealth v. Graeff, 296 Pa. Super. 480, 442 A.2d 1153, 1982 Pa. Super. LEXIS 3650 (1982).

\section{TREATISES AND ANALYTICAL MATERIALS}

1. 1 P.L.E. HEALTH AND ENVIRONMENT § 5, Pennsylvania Law Encyclopedia, HEALTH AND ENVIRONMENT, $\S 5$ Drugs and Narcotics, Copyright 2006, Matthew Bender \& Company, Inc., a member of the LexisNexis Group. 


\begin{tabular}{|c|c|c|c|}
\hline & & & $\begin{array}{c}\text { Minimum Detection } \\
\text { Limits }\end{array}$ \\
\hline Class & Substance & Schedule & (nanograms/milliliter) \\
\hline \multicolumn{4}{|l|}{ Amphetamines } \\
\hline & Amphetamine & II & 10 \\
\hline & Methamphetamine & II & 10 \\
\hline \multicolumn{4}{|l|}{ Analgesics } \\
\hline & Methadone & II & 50 \\
\hline \multicolumn{4}{|l|}{ Cannabinoids } \\
\hline & Delta-9-carboxy $\mathrm{THC}^{*}$ & $\mathrm{I}$ & 5 \\
\hline \multicolumn{4}{|l|}{ Cocaine } \\
\hline & Cocaine & II & 20 \\
\hline & Benzoylecgonine & II & 50 \\
\hline \multicolumn{4}{|l|}{ Hallucinogens } \\
\hline & Phencyclidine & II & 5 \\
\hline \multicolumn{4}{|l|}{ Opiates } \\
\hline & Codeine & II & 10 \\
\hline & Hydrocodone & II & 10 \\
\hline & Hydromorphone & II & 10 \\
\hline & 6-Monoacetylmorphine & II & 10 \\
\hline & Morphine & II & 10 \\
\hline & Oxycodone & II & 10 \\
\hline \multicolumn{4}{|l|}{ Sedatives/Hypnotics } \\
\hline & Amobarbital & II & 200 \\
\hline & Pentobarbital & II & 200 \\
\hline & Secobarbital & II & 200 \\
\hline
\end{tabular}

* $\mathrm{THC}=$ tetrahydrocannabinol 


\section{Rhode Island}

\section{Drug Specifics}

Any drug, toluene, or any scheduled controlled substance. 


\section{Utah}

\section{Drug Specifics}

Any controlled substance or metabolite thereof. 


\section{Virginia}

\section{Drug Specifics}

Cocaine, methamphetamine, phencyclidine and 3,4-methylenedioxymethamphetamine. 



DOT HS 811317

July 2010 